\title{
CARACTERIZAÇÃO TECNOLÓGICA DOS POTENCIAIS MINÉRIOS DE TERRAS-RARAS DE CATALÃO I, GO
}

\author{
REINER NEUMANN
}

Orientador: Prof. Dr. José Vicente Valarelli

\section{TESE DE DOUTORAMENTO}

COMISSÃO JULGADORA

\section{TZ706}

Nome

Presidente: Prof ${ }^{-a}$ Dr $^{\text {a }}$ Maria Cristina Motta de Toledo

Examinadores: Prof. Dr. Arthur Pinto Chaves

Prof. Dr. Daniel Atêncio

Prof. Dr. Francisco Eduardo de V. Lapido-Loureiro

Prof. Dr. José Carlos Gaspar
Assinatura

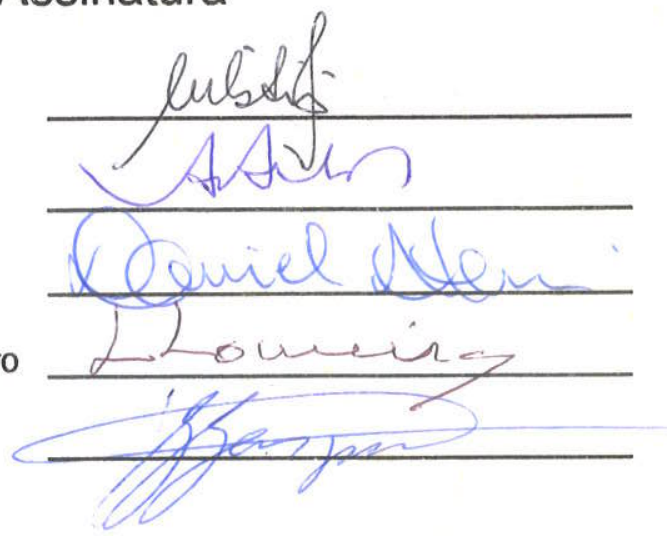

SÃO PAULO

1999 


\title{
UNIVERSIDADE DE SĀO PAULO INSTITUTO DE GEOCIENCIAS
}

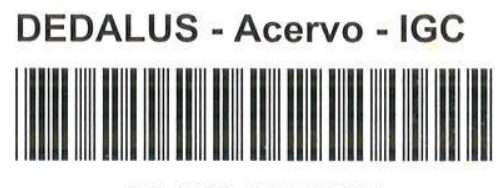

30900005327

\section{CARACTERIZAÇĀO TECNOLÓGICA DOS POTENCIAIS MINÉRIOS DE TERRAS-RARAS DE CATALÃO I, GO.}

\author{
Reiner Neumann \\ Orientador: Prof. Dr. José Vicente Valarelli \\ TESE DE DOUTORAMENTO \\ Programa de Pós-Graduação em Mineralogia e Petrologia
}


Todas as pessoas diferem entre si, têm ritmos e tempos diferentes, habilidades, dons e dificuldades diferentes, e da melhor maneira de orquestrar o conjunto de todas as aptidōes e restrições advém um estilo próprio que certamente será o mais adequado para conseguir os melhores resultados, e que será o seu estilo para toda a vida. E cada um deve aprender a melhor orquestrar suas aptidões. Por isso, quero em primeira linha agradecer ao meu caríssimo orientador, ídolo e amigo, Professor José Vicente Valarelli, por me incentivar a procurar o meu caminho, estando presente sempre que um conselho, apoio, discussão ou uma nova idéia fossem necessários, longe do conceito de linha de produção de teses premoldadas. Mais do que isso, sou grato por ir à frente com o seu exemplo de profissionalismo e integridade, que ultrapassam de longe as atribuições formais de um orientador e influenciaram decisivamente a formação do meu caráter. Isso sem falar no bom humor, nas surpreendentes idéias, no sólido conhecimento das geociências em geral, e da mineralogia e das áreas do conhecimento adjacentes em particular, e do raciocínio extremamente rápido, que tornaram qualquer conversa despretensiosa numa agradável discussão do mais alto nivel, nesses quase 14 anos de trabalho conjunto.

Esse trabalho foi integralmente desenvolvido no Centro de Tecnologia Mineral CETEM, e grande parte do que aqui apresento aprendi no CETEM ou graças a ele. Sou muito grato ao Centro por essa oportunidade, nas pessoas dos seus diretores $\mathrm{Dr}$. Roberto Villas Bôas e Dr. Fernando Freitas Lins, e agradeço a todo o corpo técnico e administrativo pelo apoio. Também contei com grande estimulo e incentivo (e cobrança) dos meus chefes diretos no Departamento de Tratamento de Minérios, Dr. Fernando Freitas Lins e Dr. Adão Benvindo da Luz, e do chefe substituto Dr. João Alves Sampaio, que fizeram o que esteve ao seu alcance para que esse trabalho pudesse ser bem desenvolvido e concluído no prazo.

Aos meus incriveis colegas no Setor de Caracterização Tecnológica, Dr. Arnaldo Alcover Neto e Adauto José da Silva, agradeço pela enorme ajuda em todas as etapas desse trabalho, e por praticamente me dispensarem do trabalho normal (que já é demais para três) nos últimos meses. Particularmente o manuseio e a preparação de amostras precisos e extremamente confiáveis do Adauto, da britagem à secção polida, certamente conferem aos dados gerados uma qualidade inicial insuperável. Boa parte do que foi sendo produzido no âmbito desse trabalho foi aprimorado pelas discussões de alto nivel com o colega e amigo Arnaldo, que, especialista no assunto, destilou 
todas as possibilidades, bombardeou conclusões que pareciam seguras e sugeriu alternativas.

Ao colega químico M.Sc. Maurilio Menezes agradeço pelo grande empenho para finalmente conseguirmos análises confiáveis de terras raras em amostras sólidas.

Agradeço ao Dr. Claudio Schneider, pesquisador pós-doutorado da University of Utah, pela iniciação ao mundo da análise de imagens e pelas ferramentas extremamente poderosas e conhecimentos de vanguarda que colocou à nossa disposição. De descrente do potencial da análise de imagem para obtenção de dados nessa envergadura, fui sendo convencido e passei a fervoroso adepto, graças aos seus argumentos irrefutáveis e personalidade arrebatadora. Agradeço também ao Prof. Dr. Peter King por facilitar o intercâmbio intenso que temos com a Universidade de Utah, onde podemos aprender na fonte.

Agradeço à Ultrafértil pelo acesso à área de estudos, em Catalão, pelas amostras e dados que me foram cedidos. Em especial, agradecimentos ao geólogo Carlos Cordeiro Ribeiro, entusiasmado pesquisador do depósito de terra raras, memória técnica e articulador dos trabalhos desenvolvidos no Córrego do Garimpo, e ao engenheiro Luiz Antonio F. Barros.

Aos meus amigos no IG-USP Flávio Carvalho, Dr. Caetano Juliani e Carmem Dantas Nunes pela ajuda com os aspectos formais da pós-graduação, como avisar no último instante que preciso entregar relatórios, fazer matrícula e outros imprevistos aparentemente inevitáveis para quem não se dedica exclusivamente à obtenção do título. Agradeço ainda ao Flávio pelo tempo que destinou a me ensinar e explicar o método de Rietveld em detalhe. O fato de não estarmos aplicando Rietveld nessa tese se deve a fatores intangíveis, e certamente a contribuição teria sido grande.

Sou imensamente grato à minha querida Marta Guerra; além da revisão implacável que evitou algumas gafes horrorosas, assumiu a dura tarefa de cuidar da nossa recém-nascida filha em periodo praticamente integral, para que eu pudesse me dedicar com exclusividade à tese, nessa reta final. E à Barbara, que me emprestou seu quarto e me poupou de escândalos excessivos.

Agradeço aos meus pais pelo incentivo e apoio para terminar essa tese.

$E$, claro, aos meus amigos que, nos momentos extra-tese, propiciam as oportunidades para arejar as idéias e descontrair: Robinson, Arnaldo, Anderson, Filipe, Otávio, Fernando, Bica, Adão, Eduardo, Caetano, Carmem, Gildo, Gelson, Sampaio e tantos outros que não citei, mas que sabem que deles falo também.

De forma direta ou indireta, esse trabalho teve o apoio do PADCT/GTM, processos 65/95/046/00, 65/95/184/00 e 818/98, PADCT/PEQ, processo 1379/95, PRONEX E PCI/MCT. 
As reservas medidas dos minérios do tipo laterítico e silexítico da região do Córrego do Garimpo, maciço alcalino-carbonatítico de Catalão I, GO, são da ordem de 30 milhões de toneladas de minério com teor médio de $7,56 \%$ de $\mathrm{TR}_{2} \mathrm{O}_{3}$.

O minério silexítico, contendo $10,05 \%$ de $\mathrm{TR}_{2} \mathrm{O}_{3}$, é composto por quartzo, monazita, hematita e goethita, com barita, cerianita, fluorapatita e hollandita subordinadas. Monazita é o principal carreador de terras raras, uma vez que a cerianita não é comum e é muito fina. A forma de ocorrência mais comum da monazita é como esferóides de poucos micrômetros de diâmetro, e com o mineral disposto em camadas concêntricas, dispersos na matriz de quartzo. A composição química da monazita inclui $57,6 \%$ de OTR, além de $3,3 \%$ de $\mathrm{Sr}$, e nenhum Th detectável, que são fatores positivos em termos de aproveitamento econômico e ambientalmente responsável do recursos.

A distribuição das terras raras nos produtos separados por tamanho, densidade e susceptibilidade magnética indica concentração apenas na fração abaixo de $20 \mu \mathrm{m}$, metade dos elementos em $36 \%$ da massa, mas contendo $43 \%$ do $\mathrm{Fe}$.

O espectro de liberação do minério, obtida a partir de análise de imagens, indica péssima liberação da monazita em relação à ganga, e da ganga em relação à monazita. Como exemplo, um concentrado com 50\% de monazita permitiria a recuperação de apenas $24 \%$ do mineral. O espectro de liberação calculado simula muito bem ensaios de concentração de trabalhos anteriores.

O minério laterítico contém $8,39 \%$ de $\mathrm{TR}_{2} \mathrm{O}_{3}$, e $23,73 \%$ de $\mathrm{Fe}_{2} \mathrm{O}_{3}$. Sua composição mineralógica é quartzo, fluorapatita, magnetita, ilmenita, hematita, goethita, monazita, gorceixita e anatásio, e subordinadamente pirocloro, priderita, vermiculita, 
hidrobiotita, zirconolita, calzirtita, baddeleyita e zircão. Os principais carreadores são a monazita, geralmente maciça mas muito porosa, e apatita. A monazita contém $57,1 \%$ de OTR, 3,3\% de Sr e novamente não contém Th. A apatita tem um teor de $1,4 \%$ de OTR, e $4,2 \%$ de $\mathrm{Sr}$, tornando esses elementos interessantes para recuperação como subproduto da fabricação de ácido fosfórico. Pirocloro, zirconolita e baddeleyita também contém ETR, mas são quantitativamente irrelevantes, enquanto que gorceixita pode apresentar até $1,6 \%$ dos elementos, apesar do mineral ser indesejado como carreador.

A distribuição das terras raras nos produtos fracionados por tamanho, densidade e susceptibilidade magnética indica concentração exclusivamente nos finos, abaixo de $20 \mu \mathrm{m}, \mathrm{com} 70 \%$ dos elementos em $44 \%$ da massa, mas contendo $46 \%$ do $\mathrm{Fe}$.

O espectro de liberação do minério laterítico confirma a má liberação da monazita em relação à ganga, mas estipula ser possível descartar metade da massa sem perdas de monazita, uma vez que a liberação da ganga em relação à monazita é bem melhor. Um concentrado com 50\% de monazita, por outro lado, recuperaria apenas $30 \%$ do mineral. Não fol possivel simular ensaios de concentração pelo espectro de liberação porque invariavelmente foi utilizada separação apenas por tamanho (deslamagem), que descaracteriza a amostra para os subsequentes testes de concentração.

O carbonatito mineralizado contém $6,64 \%$ de $\mathrm{TR}_{2} \mathrm{O}_{3}$, e é composto basicamente por magnesita, dolomita, monazita, estronianita, clinoenstatita, pirita $e$ isokita. A monazita é o único carreador importante das terras raras, com $59,7 \%$ de OTR e 4,5\% de $\mathrm{Sr}$, e ocorre em prismas de secção hexagonal com um tubo interno.

A liberação da ganga inicia-se a $64 \mu \mathrm{m}$, quando $50 \%$ está liberada, atingindo mais de $90 \%$ a $1 \mu \mathrm{m}$. A monazita, por outro lado, só está lberada a partir de $1 \mu \mathrm{m}$. 
The two distinct ore kinds - latheritic and silexitic - of the Córrego do Garimpo, Catalão I, rare eath deposit display a total mesured reserve of $30 \mathrm{Mton}$, with a mean content of $7.56 \% \mathrm{RE}_{2} \mathrm{O}_{3}$.

The mineralogical composition of the silexitic ore, containing $10.5 \% \mathrm{RE}_{2} \mathrm{O}_{3}$, is quartz, monazite, hematite and goethite, with minor barite, cerianite, fluorapatite and hollandite. Monazite is by far the most important rare earth carrier, as cerianite is uncommon and very small-sized. Monazite usually appears as spheroids a few micrometers large, dispersed through the quartz matrix. Its chemical composition shows $57.6 \%$ REO, besides $3.3 \% \mathrm{Sr}$, and no detectable Th.

The onliest concentration of the rare earths after size, density and magnetic fractioning could be acchieved in the fines of the ore $(<20 \mu \mathrm{m})$, displaying about half of the elements in $36 \%$ of the total mass, but $43 \%$ of the iron content concentrates in the fines, too.

The silexitic ore's liberation spectrum, calculated after image analysis, indicates very poor monazite liberation from its gangue, and also poor gangue liberation from the monazite. It is possible to predict, e.g., that only $24 \%$ of the monazite will be recorevered for a concentrate containing $50 \%$ of the phase. Simulations of concentration tests performed by other authors agree very well with their results.

The latheritic ore contains $8.39 \% \mathrm{RE}_{2} \mathrm{O}_{3}$, and $23.73 \% \mathrm{Fe}_{2} \mathrm{O}_{3}$. Its mineralogy is quite complex, and the main mineralogical coposition includes quartz, fluorapatite, magnetite, ilmenite, hematite, goethite, monazite, gorceixite and anatase. Pirochlore, 
priderite, vermiculite, hydrobiotite, zirconolite, calzirtite, baddeleyite and zircon were identified, too. Main rare earth carriers are monazite and apatite. Monazite contains $57.1 \% \mathrm{REO}, 3.3 \% \mathrm{Sr}$ and no detectable Th. Apatite's REO content is $1.4 \%$, and, together with its $\mathrm{Sr}$ content of $4.2 \%$, make this elements interestig for recovery as byproducts. Other minor phases may contain some RE, but are irrelevant. Gorceixite may contain up to $1.6 \% \mathrm{RE}$, but is an undesired phase for concentration purposes.

Again, the onliest concentration of the rare earths after size, density and magnetic fractioning could be acchieved in the fines of the ore $(<20 \mu \mathrm{m})$, displaying about $70 \%$ of the elements in $44 \%$ of the total mass, but $46 \%$ of the iron content concentrates in the fines, too.

The latheritic ore's liberation spectrum confirms monazite's poor liberation from its gangue, but the gangue liberation is not bad, as it is possible to discard $50 \%$ of the total mass without monazite loss. A concentrate containing $50 \%$ monazite, e.g., would come up for a monazite recovery of only $30 \%$. It has not been possible to simulate concentration tests performed by other authors using the liberation spectrum, as all the tests included desliming, and so changing all the sample's grade and size distributions.

The mineralized carbonatite, containing $6.64 \% \mathrm{RE}_{2} \mathrm{O}_{3}$, has a main mineralogy made of magnesite, dolomite, monazite, strontianite, clinoenstatite, pyrite and isokite. Monazite is the only important RE carrier, contains $59,7 \% \mathrm{REO}$ and $4,5 \% \mathrm{Sr}$, and occurs as hexagonal prisms with a cavity along the prism.

Prediction of the monazite liberation through image analysis states that monazite will be reasonably liberated only at particle sizes of about $1 \mu \mathrm{m}$. It's gangue, on the other hand, displays $50 \%$ liberation at $64 \mu \mathrm{m}$, and over $90 \%$ at $1 \mu \mathrm{m}$. 
AGRADECIMENTOS

RESUMO

ABSTRACT

ÍNDICE

ÍNDICE DE FIGURAS

ÍNDICE DE TABELAS

CAPÍTULO 1 - Introdução

XV

Objetivo

Localização e Acessos

Geologia Regional

Magmatismo Alcalino no Brasil

Geologia Local

Introdução

4

8

Encaixantes

Rochas Cretácicas

Rochas Cretacicas 10

Rochas Terciárias e Recentes 12

CAPÍTULO 2 - Trabalhos anteriores 16

Mineralogia $\quad 16$

Concentração e Metalurgia Extrativa dos ETR 30

Minério Silexítico 31

Minério Laterítico $\quad 33$

CAPÍTULO 3 - Materiais e Métodos 37

Amostras $\quad 37$

Preparação das Amostras $\quad 41$

Minério silexítico e laterítico $\quad 41$

$\begin{array}{ll}\text { Minério carbonatítico } & 42\end{array}$

Análises instrumentais $\quad 43$

Difração de raios X 43

Confecção de secções polidas $\quad 44$

Coating condutor $\quad 45$

Microscopia Eletrônica de Varredura $\quad 45$

$\begin{array}{ll}\text { Análise química } & 47\end{array}$

Análise de imagens $\quad 49$

Aquisição das imagens $\quad 49$

Processamento das imagens $\quad 51$

Correção estereológica 60

Estimativa de liberação em amostra não quebrada 65 
CAPÍTULO 4 - Resultados e Discussão 70 Minério Silexítico $\quad 70$ Análise de imagens $\quad 95$

Minério Laterítico r 106

Análise de imagens $\quad 161$

Minério Carbonatítico $\quad 172$

Análise de imagens 184

CAPÍTULO 5 - Conclusões $r$

CAPÍTULO 6 - Bibliografia 199 


\section{ÍNDICE DE FIGURAS}

Figura 1.1 - Mapa de localização de Catalão I (Carvalho, 1974).

Figura 1.2 - Mapa de provincias alcalinas do Brasil Meridional (DNPM1984).

Figura 1.3 - Mapa geológico de Catalão I (DNPM/CVRD 1986).

Figura 3.1 - Esboço geral do complexo mineiro de Catalão I, incluindo posiçâo do mapa de localização de amostras

Figura 3.2- Local de origem das amostras dos três tipos de minério estudados.

Figura 3.3 - Fluxograma do procedimento adotado para caracterização das amostras de minérios laterítico e silexítico do Córrego do Garimpo.

Figura 3.4- Fluxograma do procedimento adotado para análises químicas de $\mathrm{TR}_{2} \mathrm{O}_{3}$ e $\mathrm{Fe}_{2} \mathrm{O}_{3}$ (total) de todas as amostras nesse trabalho.

Figura 3.5 - Imagem do minério silexitico como adquirida pelo MEV, automaticamente, para análise de imagem. Cinza mais claro equivale à monazita, mais escuro (praticamente preto) à resina, cinza médio escuro ao quartzo e cinza médio mais claro a minerais de ganga (óxidos/hidróxidos de $\mathrm{Fe}$ ).

Figura 3.6 - Mesma imagem da figura anterior, após aplicação do filtro de delineação.

Figura 3.7- Imagem binária de monazita, segmentada a partir da imagem 3.6 (invertida para melhor visualização).

Figura 3.8 - Imagem binária da ganga, segmentada a partir da imagem 3.6 (invertida para melhor visualização).

Figura 3.9 - Imagem binária de monazita após preenchimento de cavidades, fraturas e outras imperfeições (invertida para melhor visualização).

Figura 3.10- Imagem binária da ganga após preenchimento de cavidades e eliminação de artefactos por mapa de distâncias euclidianas (EDM) (invertida para melhor visualização). Figura 3.11- Imagem ternária das partículas de monazita (branca), ganga (cinza) e resina (preto).

Figura 4.1 - Monazita (mais clara) em esferóides concêntricos na matriz de quartzo (MEV/BSD).

Figura 4.2 - Monazita (mais clara) em esferóides concêntricos na matriz de quartzo (MEV/BSD).

Figura 4.3 - Monazita (mais clara) vermiforme na matriz de quartzo (MEV/BSD).

Figura 4.4 - Monazita (mais clara) como massa irregular na matriz de quartzo (MEV/BSD).

Figura 4.5 - Monazita (mais clara) em esferóides concêntricos, como massas irregulares e como provável pseudomorfo (segundo pirocloro ou apatita?) na matriz de quartzo (MEV/BSD).

Figura 4.6 - Monazita (mais clara) pseudomorfa mantendo as bordas e preenchendo parcialmente, como massas irregulares, um antigo cristal (apatita?), também preenchido por óxidos/hidróxidos de Fe em cristais aciculares fibrorradiados, e quartzo (MEV/BSD).

Figura 4.7 - Monazita (mais clara) acicular fibrorradiada na matriz de quartzo, contendo ainda óxidos/hidróxidos de Fe (MEV/BSD).

Figura 4.8 - Monazita com diversas tonalidades de nivel de cinza (MEV/BSD).

Figura 4.9 - Monazita com diversas tonalidades de nivel de cinza (MEV/BSD). É possível observar uma fina trama de monazita em matriz mais escura de quartzo nas camadas mais escuras, no esferóide central e inferior esquerdo.

Figura 4.10 - Cerianita (circulos mas claros) dispersas em monazita (niveis de cinza intermediários) e quartzo. MEV/BSD.

Figura 4.11 - Cerianita (círculos mais claros) associada preferencialmente à monazita (níveis de cinza intermediários), e quartzo. MEV/BSD.

Figura 4.12 - Esferas submicrométricas de cerianita associadas preferencialmente a uma camada especifica (mais escura) de monazita, mas também a minerais de $\mathrm{Fe}$ (centro, à direita). A particula maior, no canto superior direito, é de barita. MEV/BSD. 
Figura 4.13 - Cerianita esférica muito fina associada e restrita a minerais de $\mathrm{Fe}$ aparentemente em dissolução, gerando estruturas do tipo "ghost", e quartzo com monazita
esferoidal. MEV/BSD.

Figura 4.14 . Cerianita esférica extremamente fina associada e restrita a minerais de Fe, por sua vez intercrescidos com quartzo. MEV/BSD.

Figura 4.15 - Cerianita esférica muito fina entre quartzo (esquerda) e monazita (direita). Associada à cerianita, à sua direita, ocorre uma fase de nivel de cinza intermediário entre cerianita e monazita, caracterizada como óxido de Mn e Ba. MEV/BSD

Figura 4.16 - Vista geral mostrando quartzo intercrescido com minerais de Fe, em diferentes proporções, além de monazita. MEV/BSD.

Figura 4.17 - intercrescimento muito fino entre fase de Fe e quartzo. MEV/BSD.

Figura 4.18 - Dois minerais de Fe distintos, óxido de Fe (hematita ou magnetita - mais claro) e óxido hidratado de Fe (goethita ou limonita - cinza médio), distinguíveis pelo seu nivel de cinza, intercrescidos com quartzo. O detalhe mostra o caráter acicular da fase provaveimente hidratada. MEV/BSD.

Figura 4.19 - Óxido/hidróxido de ferro acicular e monazita em quartzo. MEV/BSD.

Figura 4.20 - Liberação linear aparente do minério silexitico, obtida pela análise de imagens.
Condicional por tamanho.

Figura 4.21- Liberação em área aparente do minério silexitico, obtida pela análise de imagens. Condicional por tamanho.

Figura 4.22 - Diagrama de Hansen (L-Curves), de entropia versus resíduo, das diversas funções de transformação disponiveis utilizando os dados de liberação linear aparente obtidos para a fração $37 \times 20 \mu \mathrm{m}$ do minério silexítico. Pode ser observado que a função selecionada dolomita-esfalerita de alta resolução apresenta os menores módulos de entropia
e residuo.

Figura 4.23 - Liberação em volume do minério silexítico, obtida pela análise de imagens, após correção estereológica. Condicional por tamanho.

Figura 4.24 - Liberação em massa do minério silexitico, obtida pela análise de imagens, após correção estereológica. Condicional por tamanho.

Figura 4.25 - Monazita (mais clara) na borda de grão de quartzo (MEV/BSD).

Figura 4.26 - Imagem utilizada para a análise de imagens (MEV/BSD), com quartzo (cinza escuro), monazita (cinza mais claro) e minerais de Fe (cinza intermediário). Observar como é comum a presença de delgados niveis de monazita na superficie das partículas, inclusive naquelas compostas, de resto, exclusivamente por minerais de ganga.

Figura 4.27 - Espectro de liberação, em massa, do minério silexitico. Distribuição bivariada teor/tamanho. Liberação em massa condicional por tamanho da fração mais fina (-20 um) assumida como igual à da fração granulométrica mais próxima.

Figura 4.28 -. Recuperação de monazita em função do teor de monazita no concentrado. Minério silexitico.

Figura 4.29 - Descarte de massa em função da recuperação de monazita. Minério silexítico.

Figura 4.30 - Descarte de massa em função do teor de monazita no concentrado. Minério silexitico.

Figura 4.31 - Monazita extremamente porosa. Região mais clara ao centro do grão apresenta alto teor de Ce, Ba e Mn (MEV/BSD).

Figura 4.32 - Monazita acicular porosa muito fina (MEV/BSD).

Figura 4.33 - Intercrescimento (ou transformação) de monazita esferoidal para o tipo maciço poroso (MEV/BSD).

Figura 4.34 - Monazita muito fina no limite entre dois tipos de apatita, com niveis de cinza distintos (MEV/BSD).

Figura 4.35 - Cristal aparentemente tabular de monazita, bastante corroido, em apatita. (MEV/BSD).

Figura 4.36 - Inclusões de monazita (mais clara) em gorceixita (cinza mais escuro), com inclusões de óxidos/hidróxidos de Fe (cinza médio), que permeiam a gorceixita. MEV/BSD.

Figura 4.37 - Inclusões de monazita maciça e porosa (mais clara) em gorceixita (cinza mais escuro), além de óxido de Fe, provável magnetita (cinza médio). MEV/BSD. 
Figura 4.38 - Intercrescimento da monazita porosa com óxidos/hidróxidos de $\mathrm{Fe}$, inclusive possivelmente arranic como pode ser observado na cavidade interna. Restos de cristal

Figura 4.39 - Mon bolimento acusam barocloro com alto Pb. MEV/BSD. MEV/BSD.

Figura 4.40 - Monazita porosa associada à ilmenita (MEV/BSD).

Figura 4.41 - Monazita com niveis de cinza muito discrepantes intercrescidos. MEV/BSD

Figura 4.42 - Monazita com niveis de cinza muito discrepantes intercrescidos. MEV/BSD Figura 4.43 - Monazita com niveis de cinza muito discrepantes, possivelmente de diferentes
geraçöes. MEV/BSD.

Figura 4.44 - Inclusões de monazita muito fina em apatita com diferentes níveis de cinza.

Figura 4.45 - Grão de pirocloro com duas composições, bariopirocloro (mais escuro), e outra variedade rica em $\mathrm{Ti}, \mathrm{Ca}$ e $\mathrm{Ce}$ (mais clara). MEV/BSD

Figura 4.46 - Pirocloro rico em Pb e Ba. MEV/BSD.

Figura 4.47 - Bariopirocloro (branco) com inclusões grandes de ilmenita, gorceixita (centro, à

direita), quartzo (cinza escuro, dispersas), e monazita (no detalhe). MEV/BSD.

Figura 4,48 - Intercrescimento de zirconolita (mais escura) e calzirtita (mais clara).

Figura 4.49 - Grão com calzirtita (cinza intermediário claro) predominante, com zirconolita (cinza médio mais escuro), e gorceixita (cinza escuro, parte superior), por sua vez contendo Uma inclusão de mineral com alto Th (branco), e ilmenita (inclusão mais escura na carzirtita).

Figura 4.50 - Pequena inclusão de zirconolita (mais clara) em gorceixita (mais escura) e em ilmenita (cinza médio). MEV/BSD.

Figura 4.51 - Intercrescimento de zirconolita (cinza médio) e gorceixita (mais escura), contendo ainda restos de baddeleyita corroída (cinza bem claro, à direita) e um cristal

pequeno de bariopirocloro (claro, entre zirconolita e gorceixita, centro à esquerda).
MEV/BSD. Figura 4.52 - Zirconolita zonada (cinza médio) associada a gorceixita (mais escura) e
bariopirocloro (mais claro). MEV/BSD.

Figura 4.53 . Zirconolita zonada (mais clara) associada a apatita (cinza médio) e quartzo

Figura 4.54 - Baddeleyita fina, aparentemente restos de um cristal maior corroído.

Figura 4.55 - Baddeleyita aparentemente bem cristalizada associada a apatita. MEV/BSD.

Figura 4.56 - Baddeleyita (branco) em cristal bem formado, além de fragmentos menores,

em quartzo (cinza escuro), contendo também monazita (cinza médio). MEV/BSD.
Figura 4.57 - Gorceixita com variação de composição entre seu centro (ponto A) e sua borda

(ponto B), e com inclusão de cristal de apatita (à esquerda). MEV/BSD.

Figura 4.58 - Gorceixita dentro das folhas de hidrobiotita, ao lado de monazita maciça e
predominantemente porosa. MEV/BSD.

Figura 4.59 - Gorceixita (cinza escuro) permeada por finissima trama de óxido/hidróxido de
Fe, e ilmenita (cinza mais claro). $M E V / B S D$ Fe, e ilmenita (cinza mais claro). MEV/BSD. Figura 4.60 - Calzirtita (cinza intermediário) sobre bariopirocloro, e gorceixita (cinza escuro).
MEV/BSD.

Figura 4.61 - Associaçăo da calzirtita com gorceixita (mais escura). MEV/BSD

Figura 4.62 - Cristal bem formado de ilmenita, mais fragmentos, cimentados por apatita. No alto $\mathrm{Mn}$, para fases com observa-se passagem de ilmenita no centro, tipica no minério com alto $\mathrm{Mn}$, para fases com baixo $\mathrm{Mn}$ e perda de Fe em direção às bordas, terminando com $\mathrm{Nb}$ mais elevado na borda do grão (provável passagem para iímenorutilo). MEV/BSD. Figura 4.63 - Cristais aciculares/lenticulares de anatásio, em arranjo com alta porosidade, e
alguma monazita associada (mais clara). MEV/BSD.

Figura 4.64 - Cristais aciculares/lenticulares de anatásio em quartzo, ao lado de grão de
monazita porosa (mais clara) MEV/BSD. 
Figura 4.65 - Cristais aciculares/lenticulares de anatásio, aparentemente restando da dissoluçäo da faixa central de um cristal de priderita. MEV/BSD.

Figura 4.66 - Cristal aparentemente bem formado de priderita. MEV/BSD.

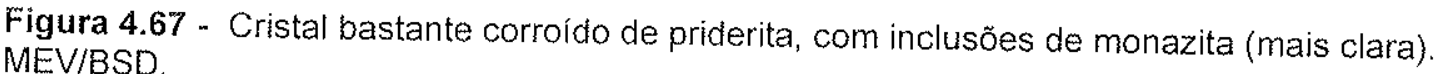

Figura 4.68 - Cristal de priderita com inclusões de ilmenita (mais clara) e apatita (mais escura), além de uma pequena de monazita (branca). MEV/BSD.

Figura 4.69 - Magnetita com exsoluções de ilmenita, mais escuras, inclusive no detalhe. A direita do grão ilmenita maciça em contato com porção da magnetita sem as exsoluçöes, podendo significar migração e concentração da ilmenita. MEV/BSD.

Figura 4.70 - Formação de cristais aciculares de óxido/hidróxido de Fe entre as folhas de vermiculita. Hidrobiotita logo acima, à esquerda. MRV/BSD.

Figura 4.71 - Crescimento de gorceixita entre as folhas de vermiculita, já substituída por óxidos/hidróxidos de $\mathrm{Fe}$, na parte superior. MEV/BSD.

Figura 4.72 - Substituição total das folhas de mica por óxidos/hidróxidos de Fe. MEV/BSD.

Figura 4.73 - Cristais de apatita soldados por óxido/hidróxido de Fe, formando cristais aciculares. MEV/BSD.

Figura 4.74 - Liberação linear aparente do minério laterítico, obtida pela análise de imagens. Condicional por tamanho.

Figura 4.75 - Liberação em área aparente do minério laterítico, obtida pela análise de imagens. Condicional por tamanho.

Figura 4.76 - L-curve de Hansen para os dados de intercepto linear obtidos por análise de imagem para a fração mais fina do minério laterítico, $37 \times 20 \mu \mathrm{m}$, onde se observa que a função de transformação dolomita-esfalerita alta resolução apresenta o menor resíduo e um módulo da entropia muito similar às curvas, de residuo muito superior.

Figura 4.77 - Liberação em volume do minério lateritico, obtida pela análise de imagens, após correção estereológica. Condicional por tamanho.

Figura 4.78 - Liberação em massa do minério lateritico, obtida pela análise de imagens, após correção estereológica. Condicional por tamanho.

Figura 4.79- Espectro de liberação natural, em massa, do minério laterítico. Distribuição bivariada teor/tamanho. Liberação em massa condicional por tamanho da traçäo mais fina ($20 \mu \mathrm{m})$ igual à da fração granulométrica mais próxima $(37 \times 20 \mu \mathrm{m})$.

Figura 4.80 - Previsão de recuperação total da monazita em função do teor de monazita no concentrado. Minério lateritico.

Figura 4.81 - Previsăo de descarte de massa no rejeito em função da recuperação da monazita no concentrado. Minério laterítico.

Figura 4.82 - Previsão de descarte de massa no rejeito em função do teor de monazita no concentrado. Minério laterítico.

Figura 4.83 - Monazita de seç̧ão hexagonal e com um tubo interno, que the confere aspecto de calha ao ser seccionada (mais clara), sobre matriz carbonática de dolomita (cinza médio) e magnesita (cinza escuro). MEV/BSD.

Figura 4.84 - Monazita de secção hexagonal (mais clara), sobre matriz carbonática de dolomita (cinza médio) e magnesita (cinza escuro). MEV/BSD.

Figura 4.85 - Monazita esferoidal com níveis concêntricos (mais clara) e isokita esferoidal fibrosa (cinza médio), sobre matriz carbonática de dolomita (cinza médio), magnesita (cinza escuro rugoso) e clinoenstatita (cinza escuro liso). MEV/BSD.

Figura 4.86 - Aglomerado de monazita (mais clara), sobre matriz carbonática de dolomita (cinza médio) e magnesita (cinza escuro). MEV/BSD.

Figura 4.87 - Monazita vermiforme (mais clara), em dolomita (cinza médio) e magnesita (cinza escuro). MEV/BSD

Figura 4.88 - Pirocloro em dolomita. MEV/BSD.

Figura 4.89 - Grande cristal de estroncianita (mais claro), aparentemente corroido, em matriz de magnesita. MEV/BSD.

Figura 4.90 - Dois cristais de estroncianita (claros, meio à direita e à esquerda) com monazita hexagonal tubular (inclusive seccionada), em matriz de dolomita (cinza médio), 
Figura 4.92 - Detalhe da figura anterior, onde é possivel reconhecer o caráter esferulítico e (mais clara) ekta, com fibras dispostas radialmente ou em feixes, associada a monazita Figura 4.93 lsoktatita (mais escura, lisa). MEV/BSD.

Figura 4.93 - Isokita esferoidal fibrosa associada a monazita (mais clara, com variaçōes de tonalidade de cinza), clinoenstatita (mais escura, lisa) e pouca dolomita (cinza médio, rugoso similares aos da Na parte central dois cristais grandes de pirita (com niveis de cinza ilmenita. MEVIBSD.

Figura 4.94 - Grande grão de pirita (cinza médio) e barita (cirza claro) no minério carbonatítico, rodeado por carbonatos (magnesita mais escura, dolomita mais clara) e monazita (cinza médio, canto inferior esquerdo), além de um cristal de galena (muito branco,
canto superior direito). MEV/BSD.

Figura 4.95 - Cristais de galena associados a provável esfalerita (detalhe), em matriz de magnesita (mais escura) e dolomita (menos escura), além de monazita (cinza médio).

Figura 4.96 - Distribuição de tamanho de interceptos (monolog) de monazita, acumulada e relativa, do minério carbonatítico.

Figura 4.97 - Distribuição de tamanho (monolog) de interceptos de ganga, acumulada e relativa, do minério carbonatítico.

Figura 4.98 - Liberação linear aparente do minério carbonatítico. Condicional por tamanho.

Figura 4.99 - Espectro de liberação em volume, após correção estereológica, do minério

carbonatítico. Condicional por tamanho.

Figura 4.100 - Liberação em massa do minério carbonatítico. Condicional por tamanho. 


\section{ÍNDICE DE TABELAS}

Tabela 1.1 - Reservas medidas de minério de ETR em Catalão I, área do Córrego do Garimpo, em função de teor de corte.

Tabela 2.1. Análise dos ETR de monazita purificada manualmente, segundo Imbernon (1993) (\% massa).

Tabela 2.2- Análise dos ETR de apatita, segundo *Imbernon (1993) e **Dutra \& Formoso (1991) (ppm)

Tabela 2.3- Análises dos ETR em apatita, segundo Pereira (1995) (ppm).

Tabela 2.4- Análise quimica (\% em massa) do minério silexitico, segundo Neumann et al (1994).

Tabela 2.5- Distribuição dos elementos terras raras, tório e urânio (\% em massa) no minério silexítico, segundo Neumann et al. (1994).

Tabela 2.6- Análises químicas pontuais (EDS ou WDS, quando marcada com *) (\% em massa) de fosfatos secundários, segundo Pereira (1995).

Tabela 2.7- Análise química (\% em massa, FRX) de concentrado de fosfato secundário ("plumbogummitas"), segundo Pereira (1995).

Tabela 2.8- Análise química dos ETR (ppm, ICP-AES) de concentrado de fosfato secundário ("plumbogummitas"), segundo Pereira (1995).

Tabela 2.9- Análise química (\% em massa) do minério lateritico, segundo Aquino \& Albuquerque (1996).

Tabela 2.10- Composição mineralógica (\% em massa) de frações classificadas por tamanho do minério laterítico, segundo Aquino \& Albuquerque (1996)

Tabela 2.11- Grau de liberação (\% em massa) do minério laterítico, segundo Aquino \&

Albuquerque (1996).

Tabela 3.1 - Magnificação e resolução das imagens adquiridas, por tamanho de particula.

Tabela 4.1 - Distribuição de tamanho de partícula do minério silexítico (\% massa).

Tabela 4.2 - Distribuição por densidade, em relação ao bromofórmio (\% massa).

Tabela 4.3 - Distribuição por suscetibilidade magnética das frações afundadas - minério silexítico (\% em massa, condicional por tamanho).

Tabela 4.4 - Distribuição por densidade e por suscetibilidade magnética das frações acima de $20 \mu \mathrm{m}$, minério silexítico (\% em massa, em relação ao total da amostra). Fração - $20 \mu$ corresponde aos $35,78 \%$ restantes.

Tabela 4.5 - Teor de $\mathrm{TR}_{2} \mathrm{O}_{3}$ e $\mathrm{Fe}_{2} \mathrm{O}_{3}$ (total), em \% em massa, na fração $105 \times 74 \mu \mathrm{m}$, e balanço de distribuição dos elementos na fração e na amostra total.

Tabela 4.6 - Teor de $\mathrm{TR}_{2} \mathrm{O}_{3}$ e $\mathrm{Fe}_{2} \mathrm{O}_{3}$ (total), em \% em massa, na fração $74 \times 53 \mu \mathrm{m}$, e balanço de distribuição dos elementos na fração e na amostra total.

Tabela 4.7 - Teor de $\mathrm{TR}_{2} \mathrm{O}_{3}$ e $\mathrm{Fe}_{2} \mathrm{O}_{3}$ (total), em \% em massa, na fração $53 \times 44 \mu \mathrm{m}$, e balanço de distribuição dos elementos na fração e na amostra total.

Tabela 4.8 - Teor de $\mathrm{TR}_{2} \mathrm{O}_{3}$ e $\mathrm{Fe}_{2} \mathrm{O}_{3}$ (total), em \% em massa, na fração $44 \times 37 \mu \mathrm{m}$, e balanço de distribuição dos elementos na fração e na amostra total.

Tabela 4.9 - Teor de $\mathrm{TR}_{2} \mathrm{O}_{3}$ e $\mathrm{Fe}_{2} \mathrm{O}_{3}$ (total), em \% em massa, na fração $37 \times 20 \mu \mathrm{m}$ e nos finos $(-20 \mu \mathrm{m})$, e balanço de distribuição dos elementos na fração e na amostra total.

Tabela 4.10 - Balanço metalúrgico $\left(\mathrm{TR}_{2} \mathrm{O}_{3} \%\right.$ massa) para o minério silexítico, e distribuiçäo por tamanho de partícula e densidade e/ou susceptibilidade magnética (negrito, em relação ao total da amostra, itálico, \% massa).

Tabela 4.11 - Balanço metalúrgico $\left(\mathrm{Fe}_{2} \mathrm{O}_{3}, \%\right.$ massa) para o minério silexitico, e distribuição por tamanho de partícula e densidade e/ou susceptibilidade magnética (negrito, em relação ao total da amostra, itálico, \% massa). Tabela 4.12 - Composição mineralógica, conforme identificada por DRX, da fraçăo $105 \times 74$
$\mu \mathrm{m}$.

Tabela 4.13 - Composição mineralógica, conforme identificada por DRX, da fração $74 \times 53$ $\mu \mathrm{m}$.

Tabela 4.14 - Composição mineralógica, conforme identificada por DRX, da fração $53 \times 44$ 
Tabela 4.15 - Composição mineralógica, conforme identificada por DRX, da fraçäo $44 \times 37$ $\mu \mathrm{m}$.

Tabela 4.16 - Composição mineralógica, conforme identificada por DRX, da fração $37 \times 20$ um, e dos finos $(-20 \mu \mathrm{m})$.

Tabela 4.17 - Análises comparativas de regiões mais claras e escuras de três grãos onde essas regióes poderiam permitir resolução melhor do detector de EDS (\% em massa).

Tabela 4.18 - Análises químicas pontuais (por EDS, \% em massa) de monazita de Cataläo recalculadas após subtração de sílica. Média em negrito, na última linha.

Tabela 4.19 - Análises quimicas pontuais (por EDS, \% em massa) de cerianita de Catalão, recalculas após subtração de sillica.

Tabela 4.20 - Teores de monazita de ponto, linha e area, medidos por análise de imagens, cabeça composta de monazita desconsiderando a fração fina, $-20 \mu \mathrm{m}$, e teor de $\mathrm{TR}_{2} \mathrm{O}_{3}$ de cabeça calculado a partir da monazita e da análise química da fração fina, $-20 \mu \mathrm{m}$.

Tabela 4.21 - Distribuição de tamanho de partículas do minério silexítico (\% massa).

Tabela 4.22 - Distribuição por densidade, em relação ao bromofórmio (\% massa).

Tabela 4.23 - Distribuição por suscetibilidade magnética das frações afundadas - minério laterítico (\% em massa, condicional por tamanho).

Tabela 4.24 - Distribuição por densidade e por suscetibilidade magnética das frações acima de $20 \mu \mathrm{m}$, minério laterítico (\% em massa, em relação ao total da amostra). Fração $-20 \mu$ corresponde aos $43,52 \%$ restantes.

Tabela 4.25 - Teor de $\mathrm{TR}_{2} \mathrm{O}_{3}$ e $\mathrm{Fe}_{2} \mathrm{O}_{3}$ (total), em \% por peso, na fração $105 \times 74 \mu \mathrm{m}$, e balanço de distribuição dos elementos na fração e na amostra total.

Tabela 4.26 - Teor de $\mathrm{TR}_{2} \mathrm{O}_{3}$ e $\mathrm{Fe}_{2} \mathrm{O}_{3}$ (total), em \% por peso, na fração $74 \times 53 \mu$ m, e balanço de distribuição dos elementos na fração e na amostra total.

Tabela 4.27 - Teor de $\mathrm{TR}_{2} \mathrm{O}_{3}$ e $\mathrm{Fe}_{2} \mathrm{O}_{3}$ (total), em \% por peso, na fração $53 \times 44 \mu \mathrm{m}$, e balanço de distribuição dos elementos na fração e na amostra total.

Tabela 4.28 - Teor de $\mathrm{TR}_{2} \mathrm{O}_{3}$ e $\mathrm{Fe}_{2} \mathrm{O}_{3}$ (total), em \% por peso, na fração $44 \times 37$ um, e balanço de distribuição dos elementos na fração e na amostra total.

Tabela 4.29 - Teor de $\mathrm{TR}_{2} \mathrm{O}_{3}$ e $\mathrm{Fe}_{2} \mathrm{O}_{3}$ (total), em \% por peso, na fração $37 \times 20 \mu \mathrm{m}$ e dos finos $(-20 \mu \mathrm{m})$, e balanço de distribuição dos elementos na fração e na amostra total.

Tabela 4.30 - Balanço metalürgico $\left(\mathrm{TR}_{2} \mathrm{O}_{3}, \%\right.$ massa) para o minério laterítico, e distribuição por tamanho de particula e densidade e/ou susceptibilidade magnética (negrito, \% em relação ao total da amostra, itálico, \% massa).

Tabela 4.31 - Balanço metalúrgico ( $\mathrm{Fe}_{2} \mathrm{O}_{3} \%$ massa) para o minério silexítico, e distribuição por tamanho de particula e densidade e/ou susceptibilidade magnética (negrito, em relação ao total da amostra, itálico, \% massa).

Tabela 4.32 - Composição mineralógica, conforme identificada por DRX, da fração $105 \times 74$ $\mu \mathrm{m}$.

Tabela 4.33 - Composição mineralógica, conforme identificada por DRX, da fração $74 \times 53$ um.

Tabela 4.34 - Composição mineralógica, conforme identificada por DRX, da fração $53 \times 44$ ...m.

Tabela 4.35 - Composição mineralógica, conforme identificada por DRX, da fração $44 \times 37$ um.

Tabela 4.36 - Composição mineralógica, conforme identificada por DRX, da fração $37 \times 20$ $\mu \mathrm{m}, \mathrm{e}$ dos finos $(-20 \mu \mathrm{m})$.

Tabela 4.37 - Análises comparativas de regiões mais claras e escuras de quatro grãos de monazita (\% por peso), recalculadas para $100 \%$.

Tabela 4.38 - Análises de EDS de monazita (\% massa), recalculadas para 100\%. Valores médios na última linha, em negrito.

Tabela 4.39 - Análises de EDS de apatita (\% massa). Valores médios na última linha, em negrito.

Tabela 4.40 - Composição de alguns pirocloros contendo ETR identificados no minèrio lateritico (EDS, \% em massa).

Tabela 4.41 - Composição da inclusão rica em Th, mais clara, da imagem da Figura 4.49 (EDS, \% em massa, recalculado para 100\%). 
Tabela 4.42 - Composição de grãos de zirconolita (EDS, \% em massa). Última coluna, em negrito, apresenta a média das análises.

Tabela 4.43 - Composição de alguns grãos de baddeleyita do minério lateritico (EDS, \% em massa, recalculado para $100 \%$ ). Média na última coluna, em negrito.

Tabela 4.44 - Composição química de alguns grãos de gorceixita (incluindo os pontos $\mathrm{A}$ e $\mathrm{B}$ da Figura 4.55 ), dados de EDS (\% em massa, recalculados para $100 \%$ ).

Tabela 4.45 - Composição de diversos grãos de calzirtita (EDS, \% massa).

Tabela 4.46 - Composição de dois grãos de ilmenita (EDS, \% em massa, recalculado para $100 \%)$.

Tabela 4.47 - Composição de anatásio, determinada por EDS (\% massa, recalculada para $100 \%)$.

Tabela 4.48 - Composição quimica de priderita (EDS, \% massa, não recalculado).

Tabela 4.49 - Composição quimica de algumas hidrobiotitas e vermiculita (EDS, \% massa)

Tabela 4.50 - Teores de monazita de ponto, linha e área, medidos por análise de imagens, cabeça composta de monazita desconsiderando a fração fina, $-20 \mu \mathrm{m}$, e teor de $\mathrm{TR}_{2} \mathrm{O}_{3}$ de cabeça calculado a partir da monazita e da análise química da fração fina, - $20 \mu \mathrm{m}$.

Tabela 4.51 - Composições quimicas de monazitas no carbonatito. Medidas (EDS, \% em massa) recalculadas após subtração de Si. Média em negrito na última linha. Figura 4.74 Tabela 4.52 - Composição química do pirocloro da figura 4.88 (EDS, \% massa).

Tabela 4.53 - Composições quimicas de alguns pontos de magnesita e dolomita. Análises qualitativas por EDS, \% em massa.

Tabela 4.54 - Análises qualitativas de estroncianita. EDS, \% em massa.

Tabela 4.55 - Composição de isokita (EDS, \% em massa). 


\section{CAPÍTULO 1 Introdução}

Os metais de terras raras - denominação recomendada pela IUPAC (1960) - (ou elementos terras raras, ou terras raras) pertencem ao grupo III-B da tabela periódica, e incluem Sc, $Y$ e La a Lu, inclusive. Pelas suas propriedades químicas, predominantemente iônicas e com fenômeno de contração iônica (significativa diminuição do tamanho dos átomos e dos íns com aumento do número atômico), e dominadas pela camada elétrica $4 \mathrm{f}$, as terras raras apresentam importantes aplicações tecnológicas (Abrão 1994). Como exemplo, Lapido Loureiro (1994) cita aços especiais, catálise (para craqueamento de petróleo e catalisadores automotivos), cerâmicas avançadas, vidros, magnetos permanentes, fósforos, sensores de oxigênio e muitos outros.

O Brasil, que já havia acumulado metade da produção mundial de ETR de 1886 a 1960 , passou a modestos $2,5 \%$ no início da década, e atualmente não produz nada. A única usina de produção da INB (Indústrias Nucleares Brasileiras, que inclui a antiga NUCLEMON), em Santo Amaro, foi fechada, mas esperamse que a produção seja reiniciada em meados de 1999, nas instalações em Poços de Caldas. Inicialmente, a INB deve processar o concentrado de monazita obtido na remodelada usina de concentração em Buena, a partir de areias de praias e cordões litorâneos, produzindo óxido de Ce e carbonato de La para catalisadores, respectivamente, automotivos e de craqueamento de petróleo. Apesar de dispor de tecnologia para produção dos elementos individualizados com maior pureza, e consequentemente com valor agregado muito superior, a INB gerará apenas os produtos mencionados, contendo os outros ETR, uma vez que a escala de produção, consumindo as aproximadamente 60 toneladas mensais de concentrado produzido em Buena, não justifica a complexidade 
tecnológica requerida (INB, informação verbal). A empresa tem atualmente todo o interesse em se associar a eventuais produtores de terras raras para viabilizar um processo que agregue valor aos seus produtos.

O depósito do Córrego do Garimpo está entre as melhores reservas e teores de terras-raras do país, representando, segundo Lapido Loureiro \& Barbosa (1993) e Lapido Loureiro (1994), por volta de 2,3\% dos recursos identificados no Brasil. Recente atualização das reservas medidas no Córrego do Garimpo (Ultrafértil, dez/1998, informação verbal) mais do que triplicou esses recursos. A Tabela 1.1 apresenta reservas medidas para diversos teores de corte de $\mathrm{TR}_{2} \mathrm{O}_{3}$ e teores médios resultantes, num cálculo considerado pelo responsável (geólogo Carlos Cordeiro Ribeiro Ultrafértil) extremamente conservador. Considerando um consumo nacional ao redor de 3.000 ton anuais, os OTR contidos no minério, numa eventual lavra com teor de corte de $5 \%$ (ou seja, $30 \mathrm{Mt}$ com teor médio de $7,56 \%$ de $\mathrm{TR}_{2} \mathrm{O}_{3}$ ), são suficientes para 768 anos de consumo. Esses números são apenas ilustrativos da importância da jazida e da necessidade de se desenvolver tecnologia para o seu desenvolvimento.

Tabela 1.1 - Reservas medidas de minério de ETR em Catalão I, área do Córrego do Garimpo, em função de teor de corte.

\begin{tabular}{ccc}
$\begin{array}{c}\text { Teor de corte } \\
\left(\% \mathrm{TR}_{2} \mathrm{O}_{3}\right)\end{array}$ & $\begin{array}{c}\text { Teor médio } \\
\left(\% \mathrm{TR}_{2} \mathrm{O}_{3}\right)\end{array}$ & $\begin{array}{c}\text { Reserva Medida } \\
\left(10^{3} \text { ton }\right)\end{array}$ \\
\hline 2 & 5,56 & 60.856 \\
5 & 7,56 & 30.478 \\
8 & 10,47 & 9.218 \\
10 & 12,81 & 3.841 \\
12 & 14,06 & 2.293 \\
\hline
\end{tabular}

A alta complexidade dos minérios, devida à grande variabilidade mineralógica, uma origem geológica ainda não bem compreendida que resulta numa associação complexa de diferentes litologias e minérios originais e intensa laterização 
superimposta, exige tecnologia específica para viabilizar o seu aproveitamento, partindo-se de uma caracterização mineralógica e tecnológica precisa.

\section{Objetivo}

O objetivo desse trabalho é a caracterização tecnológica dos potenciais tipos de minério de ETR provenientes do maciço alcalino-carbonatítito de Catalão I, GO, como subsidio ao desenvolvimento de rotas de beneficiamento e/ou metalurgia extrativa para recuperaçăo dos referidos elementos. Dentro da filosofia de desenvolvimento sustentável, a caracterização visa fornecer informações para que haja o máximo de aproveitamento dos recursos naturais, com um mínimo de consumo de energia e de conseqüências ambientais.

\section{Localização e Acessos}

O Complexo Ultramáfico Alcalino de Catalão I situa-se no Município de Ouvidor, comarca de Catalão, no sudeste do Estado de Goiás, a aproximadamente $280 \mathrm{~km}$ ao sul de Brasilia. Tem, aproximadamente, as seguintes coordenadas geográficas: $18^{\circ} 20^{\prime}$ de Latitude Sul e $48^{\circ} 20^{\prime}$ de Longitude Oeste. Dista $20 \mathrm{~km}$ a nordeste da cidade de Catalão e $10 \mathrm{~km}$ a norte da cidade de Ouvidor (Figura 1.1).

A região pode ser acessada por carro a partir de Brasilia, pelas BR-050 e BR040, ou por Uberaba e Uberlândia, pela BR-040. Essas cidades possuem aeroportos servidos regularmente por empresas de aviação comercial. $O$ acesso ao complexo de Catalão I parte da própria BR-050, principalmente seguindo as indicações para as mineradoras Ultrafértil e Mineração Catalão de Goiás. 


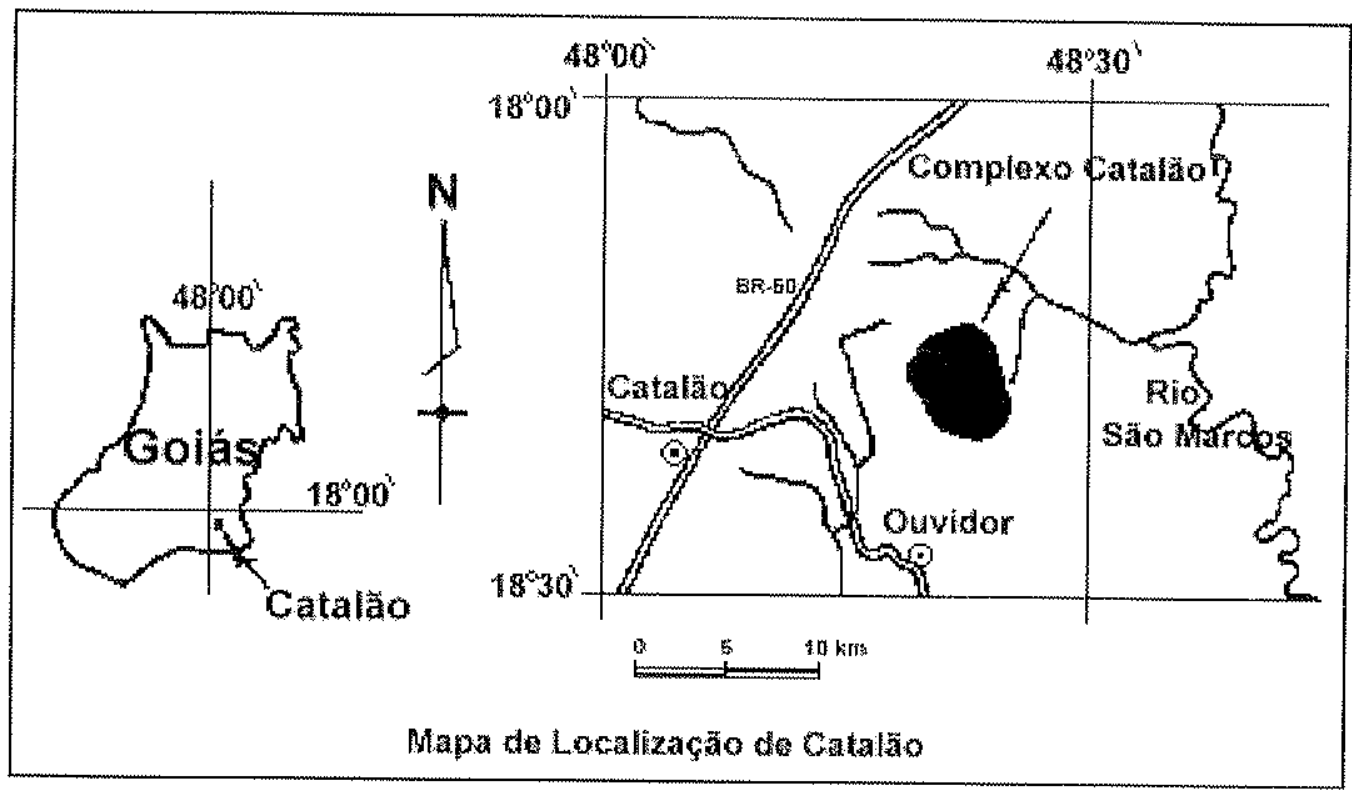

Figura 1.1 - Mapa de localização de Catalão I (Carvalho, 1974).

\section{Geologia Regional}

\section{Magmatismo Alcalíno no Brasil}

A província alcalina do Brasil meridional é importante por seu elevado interesse econômico e também por ser uma das grandes e clássicas áreas de interesse petrogenético do mundo. Mais de cinqüenta intrusöes alcalinas, com ou sem associação de carbonatitos e kimberlitos, são notadas principalmente na periferia da Bacia do Paraná. Os dados geológicos regionais indicam uma forte relação entre unidades estruturais maiores e o emplacement dos maciços alcalinos. Isto indica que os corpos alcalinos formam pelo menos dois alinhamentos distintos: um, aproximadamente paralelo à costa, com direção nordeste-sudoeste e o outro, com trend nor-noroeste. O magmatismo alcalino está associado a grandes fenômenos geológicos do início no Eojurássico, que podem também ser relacionados à deriva continental (Herz 1977, Asmus 1978). 
O mapa de províncias alcalinas do Brasil meridional encontra-se na Fig. 1.2.

O Complexo de Cataläo I foi incluido por Ulbrich \& Gomes (1981) na sua província do Alto Parnaíba, juntamente com outros complexos (Araxá, Catalão II, Salitre I e II, Tapira), todos intrusivos em metassedimentos proterozóicos ao longo da margem sudeste do Craton do São Francisco. Uma feição comum aos complexos dessa província é a presença de auréola de fenitização, que pode atingir até $2 \mathrm{~km}$ de espessura.

Segundo Ulbrich \& Gomes (1981), de acordo com as datações radiométricas até agora disponíveis, três grupos de idades de rochas alcalinas podem ser definidos:

1) O mais antigo é representado pelo maciço de Pão-de-Açúcar ou Fecho dos Morros, MS. Os valores variam de 239 a 209 Ma, o que permite situá-lo no Triássico, considerando-se uma média de $220 \mathrm{Ma}$. Estes dados indicam que as alcalinas que flanqueiam a borda oeste da Bacia do Paraná são mais antigas que as correspondentes do interior da bacia. Possivelmente se relacionam a uma fase precoce do evento Sul-Atlantiano.

2) O segundo grupo possui idades em torno de $130 \mathrm{Ma}$ (Jurássico) e a maior parte dos seus correspondentes afloram próximo ao maciço de Jacupiranga (ocorrência-tipo).

3) A atividade alcalina cai entre 70 e $128 \mathrm{Ma}$, aproximadamente, e retorna com grande intensidade no Eocretáceo, chegando até o Eoceno. Neste grupo de idades está incluída a maior parte das rochas alcalinas do sul do Brasil, principalmente os maciços e ocorrências da faixa de Minas Gerais - Goiás e da faixa costeira São Paulo -

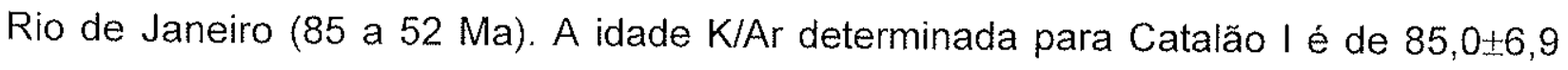
Ma (sienito, Sonoki \& Garda 1988) a 91,8 3,3 Ma (flogopitas, Imbernon 1993). 
De acordo com descrições petrográficas, a faixa de Minas Gerais-Goiás é classificada por Ulbrich \& Gomes (1981) como associação muito complexa, máfica a ultramáfica, álcali-saturada a peralcalina com glimmeritos, dunitos, peridotitos e piroxenitos como rochas dominantes. Algumas rochas estão acompanhadas de carbonatitos e outras não. Outras ainda têm glimmeritos como rocha silicatada principal, além de diques e plugs de carbonatitos (Catalão I).

Utilizando-se de dados petrográficos, idades e argumentos de ordem regional, a faixa de Minas Gerais - Goiás é definida como sendo uma província máfico-ultramáfica, portadora de carbonatitos (muito enriquecida em Ti, $\mathrm{Zr}, \mathrm{Nb}, \mathrm{P}, \mathrm{ETR}$ e, às vezes, $\mathrm{U} e$ Th).

Os complexos alcalinos e carbonatitos associados possuem uma elevada gama de mineralizações ( $\mathrm{P}, \mathrm{Nb}, \mathrm{Ti}, \mathrm{Ni}, \mathrm{U}, \mathrm{Zr}$, ETR, Th, Al, Ba, Mo, F e vermiculita), diversos dos quais hospedam grandes depósitos de interesse comercial, geralmente constituindo concentrações residuais ligadas a processos de intemperismo.

As principais jazidas de fosfato (apatita) estão relacionadas aos complexos de Tapira e Araxá (MG), Catalão I (GO) e, subordinadamente, a Jacupiranga (SP) e Anitápolis (SC). O nióbio (pirocloro), do qual o Brasil é o maior produtor mundial, está relacionado principalmente aos carbonatitos dos complexos ultramáfico-alcalinos de Araxá, Cataläo I, Tapira e também Serra Negra (MG). O titânio, sob a forma de ilmenita, perovskita, anatásio, titanita, rutilo e leucoxênio (denominação genérica de produtos de alteração dos outros minerais, óxidos/hidróxidos de Ti amorfos, ou titanita/anatásio/rutilo microcristalinos), concentra-se nos complexos de Tapira, Catalão I e Salitre-Serra Negra (MG). Em Catalão I, a mineralização de titânio pode associar-se à apatita e à vermiculita, em solos residuais. Minerais de terras-raras estão presentes 
em Catalão l e Araxá. Finalmente deve-se citar os depósitos de vermiculita de Cataläo I e Santa Fé (GO).

A faixa de Minas Gerais - Goiás pode ser dividida em duas provincias plutovulcânicas de natureza ultrabásica alcalina e carbonatítica, de idade neocretácica, ambas situadas nas adjacências de uma grande zona de arqueamento crustal (arco do Alto Paranaiba) (DNPM 1984).

A província do oeste de Minas Gerais representa um conjunto de intrusões dòmicas de natureza ultrabásico-carbonatítica, exemplificadas pelos complexos de Tapira, Araxá, Salitre, Serra Negra e Catalão I e II; e por grandes depósitos de lavas e de rochas vulcanoclásticas ultrabásicas alcalinas, que compõem as formações Uberaba e Mata da Corda (Hasui 1968, Ladeira et al. 1971).

O magmatismo cretácico se encontra balizado por falhas normais de direções NW e N70E. Este controle tectônico é resultado de arqueamentos crustais, relativos a movimentos isostáticos às margens da Bacia do Paraná. 


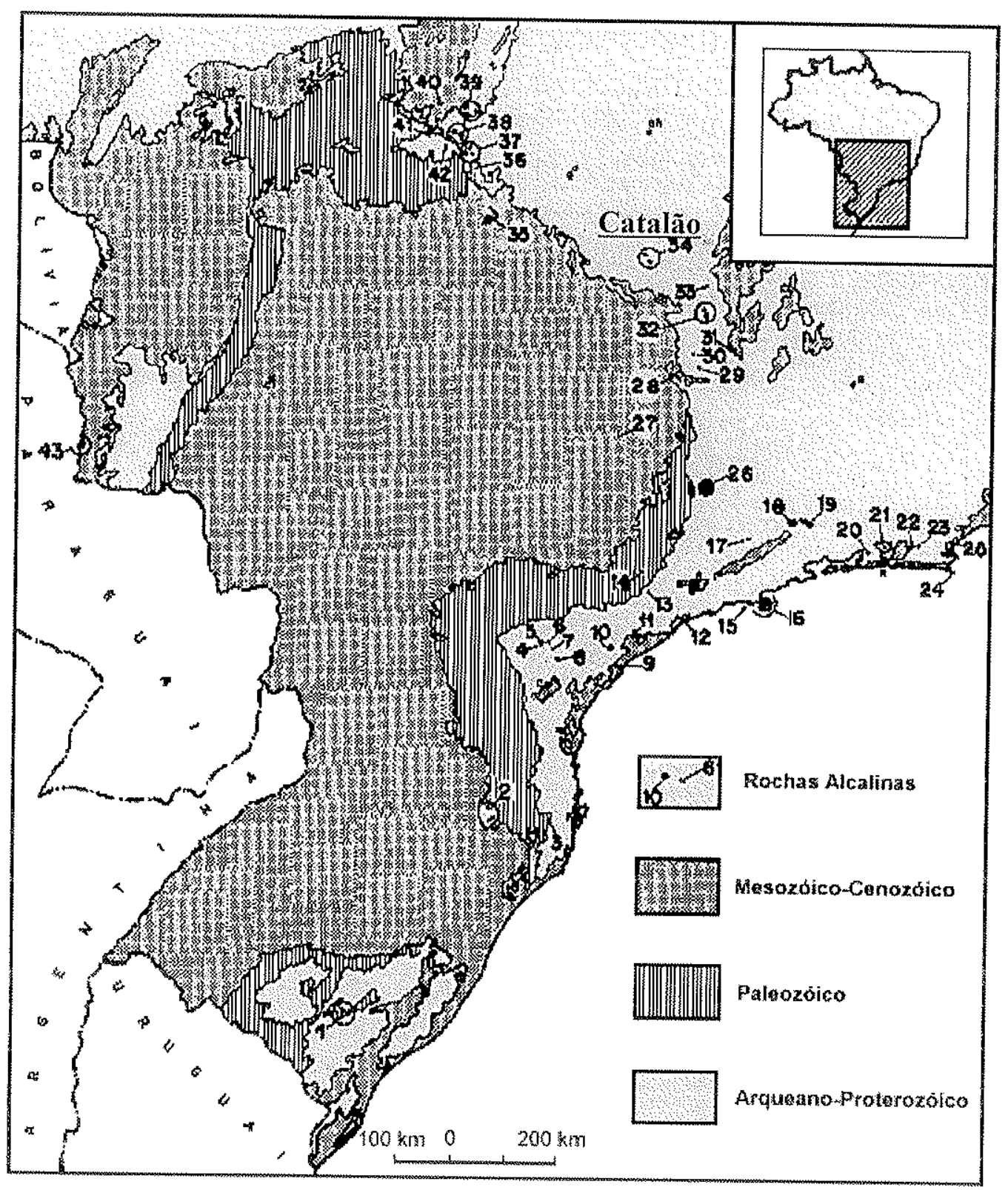

Figura 1.2- Mapa de províncias alcalinas do Brasil Meridional (DNPM1984).

\section{Geologia Local}

\section{Introdução}

O Complexo Ultramáfico-Alcalino de Catalão I é formado por um núcleo de rochas ígneas, com rochas metamórficas como encaixantes, sendo a capa arqueada 
em forma dômica. O domo, truncado pela superfície de aplainamento, coincide com o próprio platô, que tem sua preservação dada por um anel resistente de quartzito em torno do corpo ígneo. No topo do platô encontra-se um manto de intemperismo de até $250 \mathrm{~m}$ (Carvalho 1974) (Figura 1.3).

\section{Encaixantes}

Catalão, no sudeste de Goiás, faz parte de uma região constituída de rochas pré-cambrianas. Predominam metamorfitos de fácies epidoto-anfibolito, formados principalmente por micaxistos com intercalações de delgados leitos e lentes de quartzitos e raros anfibolitos, correspondentes ao Grupo Araxá. Estas rochas servem de encaixantes à intrusão ultramáfica-alcalina de Catalão I (Barbosa et al. 1970).

Regionalmente, a xistosidade das rochas do Grupo Araxá é NW-SE, mergulhando para sudoeste. Nas adjacências da intrusão, encontram-se arqueadas, com estrutura dômica.

Próximo ao contato ígneo, formou-se uma auréola de fenitização (resultado das modificações sofridas pelas rochas encaixantes por ação das soluções de origem ígnea). A intensidade de fenitizaçäo diminui radialmente para fora, de maneira irregular.

Os tipos petrográficos desta faixa de alteração podem ser citados de acordo com sua importância quantitativa, como quartzitos fenitizados, xistos fenitizados, brechas e sienitos nefeliníticos.

A paragênese mineral é caracterizada por ser rica em feldspatos potássicos, piroxênios/anfibólios sódicos e relativamente pobre em quartzo. 
Restritos leitos de gonditos estão associados a estas rochas, mas não estando relacionados ao processo de fenitização, podendo ser anteriores à intrusão do complexo ígneo de Catalão I.

Veios pegmatíticos, de poucos metros de espessura, podem cortar todas essas rochas, mas sua relação com os fenômenos de fenitização descritos é duvidosa.

\section{Rochas Cretácicas, segundo Carvalho (1974)}

Os litotipos encontrados em Catalão I podem ser agrupados em i) rochas ultramáficas e metassomáticas, ii) rochas carbonatíticas e iii) fenitos. São em sua maioria rochas ricas em flogopita, havendo alguns corpos de piroxenito e peridotito, últimos representantes das rochas ultramáficas originais de Catalão I, que sofreram grandes transformações metassomáticas a partir de sua cristalização (Carvalho 1974, Danni et al. 1991). Estas rochas são cortadas por uma ou mais gerações de veios carbonatíticos.

Em ordem decrescente quanto à seqüência e intensidade dos fenômenos ocorridos, quatro importantes processos de transformação podem ser notados: flogopitização, serpentinização, carbonatização e silicificação.

A flogopitização resultou do intenso metassomatismo potássico a que foram submetidos os peridotitos e piroxenitos originais, com a flogopita substituindo os piroxênios e a olivina. O processo se deu em todo o corpo ígneo, ocorrendo mais intensamente na sua periferia, formando rochas muito ricas em flogopita: os glimmeritos. Os depósitos de vermiculita atuais são prova das suas áreas preferencias de ocorrência, uma vez que este mineral é derivado da alteração meteórica da flogopita. 
A serpentinização se deu de forma restrita em Catalão l e em menor escala sobre os piroxenitos e peridotitos.

A carbonatização é notável, não só pelos inúmeros veios de carbonatos que cortam desordenadamente os glimmeritos, peridotitos e piroxenitos serpentinizados, como também pela existência de carbonatos intersticiais nas rochas seccionadas por esses veios. A carbonatização é mais intensa na porção central da estrutura, com a formação de um plug central, cujo teto encontra-se totalmente silicificado. O conjunto dos veios com as rochas ultramáficas do complexo cortadas por eles é denominado de silicocarbonatito.

A intensidade da silicificação dos carbonatitos nas porções centrais da estrutura foi intensa, independentemente da sua origem, existindo furos de sonda que cortaram mais de $100 \mathrm{~m}$ de puro silexito, sem encontrar o carbonatito típico.

Os silicocarbonatitos são constituídos essencialmente de flogopita e secundariamente de serpentina, que pode eventualmente ser o principal constituinte. A rocha geralmente é cortada por pequenos veios de carbonatos de duas ou mais gerações.

Os sövitos (veios carbonatíticos calcíticos) de Catalão 1, de duas ou mais gerações, são constituidos essencialmente de calcita e, secundariamente, de apatita e flogopita.

Os glimmeritos ocorrem preferencialmente na periferia do complexo e são constituídos principalmente por flogopita. Esta rocha pode ser cortada por finissimas vênulas preenchidas por carbonatos.

Os silexitos ocorrem em várias partes da intrusão e na sua periferia. Em profundidade aparecem em toda a intrusão e o seu comportamento é caótico, podendo 
ocorrer intercalados ao material alterado, nas mais diversas direções. Os silexitos são muito abundantes na porção central da rocha intrusiva.

Além de quartzo e calcedônia (na verdade, uma variedade de quartzo), os silexitos podem conter ainda magnetita, pirita, barita, apatita e minerais portadores de terras-raras.

\section{Rochas Terciárias e Recentes, segundo Carvalho (1974)}

A partir do Terciário, todo o Planalto Central Brasileiro foi submetido a intensos processos de laterização. No Complexo Ultramáfico-Alcalino de Catalão 1 e adjacências, a intensidade dos fenômenos de alteração foi grande, levando ao aparecimento de crostas limoníticas e solos lateríticos bastante espessos.

O Laterito Nodular e a Canga Rica em Magnetita são dois diferentes tipos de crostas e solos lateríticos reconhecidos em Catalão l e áreas vizinhas.

Além destes materiais de alteração, são encontrados sedimentos argilosos de possivel idade terciária, localizados na Lagoa Seca (depressão central da estrutura).

O Laterito Nodular é proveniente da laterização das rochas do Grupo Araxá e ocorre fora dos limites da intrusăo, acompanhando as bordas fenitizadas, principalmente a oeste. Difere-se dos outros lateritos pela grande quantidade de quartzo e pela ausência de magnetita.

As Cangas Ricas em Magnetita são pouco espessas (não ultrapassam $15 \mathrm{~m}$ ) e ocorrem isoladamente em aglomerados de grandes matacões por toda a área da intrusão. Esta canga, por seu aspecto e pela grande quantidade de magnetita, destacase sensivelmente dos lateritos originados dos metamorfitos do Grupo Araxá. 
O Conglomerado Limonítico é uma canga conglomerática que possui seixos e blocos de materiais variados, aglutinados por cimento magnetítico e limonítico. Sua ocorrência é restrita às proximidades da borda norte. Diferencia-se da rica em magnetita pela presença de blocos e seixos de quartzito e silexito. Os seixos são englobados por matriz de óxido de ferro e contêm magnetita submilimétrica. Os seixos, sem selecionamento, podem estar rolados, sub-rolados ou brechados. Grandes cristais de magnetita (centimétricos, segundo Valarelli 1971) podem ser observados.

O Solo Laterítico Rico em Vermiculita localiza-se junto à borda leste da intrusão. Nas partes mais dissecadas, ocorre um solo amarelo, argiloso, muito rico em palhetas de vermiculita, com seixos irregulares e concreções silicosas. É pobre em magnetita e contém ilmenita e anatásio. É o produto de alteração de rochas ricas em flogopita, ou seja, os glimmeritos.

O Solo Lateritico Rico em Magnetita ocupa a porção oeste da intrusão. Sua cor pode variar de amarelo a vermelho. É argiloso e contém magnetita, ilmenita, hematita (pseudomorfo segundo magnetita), quartzo (incluindo a versão calcedônia), barita e eventualmente apatita. Esta unidade cobre aproximadamente dois terços da área da intrusão.

Os Sedimentos Argilosos se localizam, como antes dito, na depressão central da estrutura (Lagoa Seca) e possuem aproximadamente $150 \mathrm{~m}$ de espessura. Foram possivelmente transportados e sobrepostos aos silexitos. A presença de seixos rolados no fundo da Lagoa Seca e de seus sedimentos, abaixo das crostas limoníticas terciárias, permite uma conclusão de que a depressão já constituía, no Terciário, uma grande cavidade, com pelo menos $150 \mathrm{~m}$ de profundidade, que foi totalmente preenchida por material transportado das encostas vizinhas. Tudo indica que no local em questão ocorreu a formação do stock carbonatitico principal do complexo e que, 
antes de sua silicificação, desenvolveu-se uma dolina de dissolução ou um desmoronamento com as dimensões da atual depressão. Os sedimentos são constituídos de argilas plásticas, cauliniticas, extremamente finas, de cor branca a cinza claro, com eventuais cristais de vivianita.

O intemperismo, segundo Imbernon (1993), deu-se essencialmente in situ e as principais transformações foram assim hierarquizadas: estágio inicial caracterizado por dissolução dos carbonatos e concentração relativa de apatita, minerais acessórios e flogopita (transformada em vermiculita), bem como de quartzo neoformado resultante da hidrólise dos silicatos. A vermiculita tende a desaparecer no estágio seguinte, que também se caracteriza pela formação e acumulação de fosfatos aluminosos e barita secundários. No estágio final formam-se os sesquióxidos de $\mathrm{Fe}$ e caolinita, e dissolvem-se a apatita e o quartzo. As jazidas de apatita são essencialmente residuais, e a autora não observou apatita secundária. As concentrações de ETR, por outro lado, são hidrotermais, associadas à barita em matriz extremamente silicificada, ou intempéricas, por alteração desse primeiro tipo, fixando os ETR em fases do tipo fosfatos aluminosos do grupo da crandallita/plumbogumita.

De uma maneira geral, o perfil de alteração foi descrito por Oliveira \& Imbernon (no prelo) como gradando de rocha fresca a saprolito isalterítico, depois a saprolito aloterítico até uma cobertura alóctone rosada. A rocha fresca é descrita como um foscorito abundantemente cortado por veios carbonatíticos, enquanto no saprolito isalterítico predomina apatita, além de goethita, quartzo e pequenas quantidades de alumino-fosfatos secundários do grupo da plumbogumita. Essas fases, goethita, quartzo e fosfatos secundários, predominam no saprolito aloteritico. O conteúdo em ETR aumenta com a intensificação da alteração da rocha. 


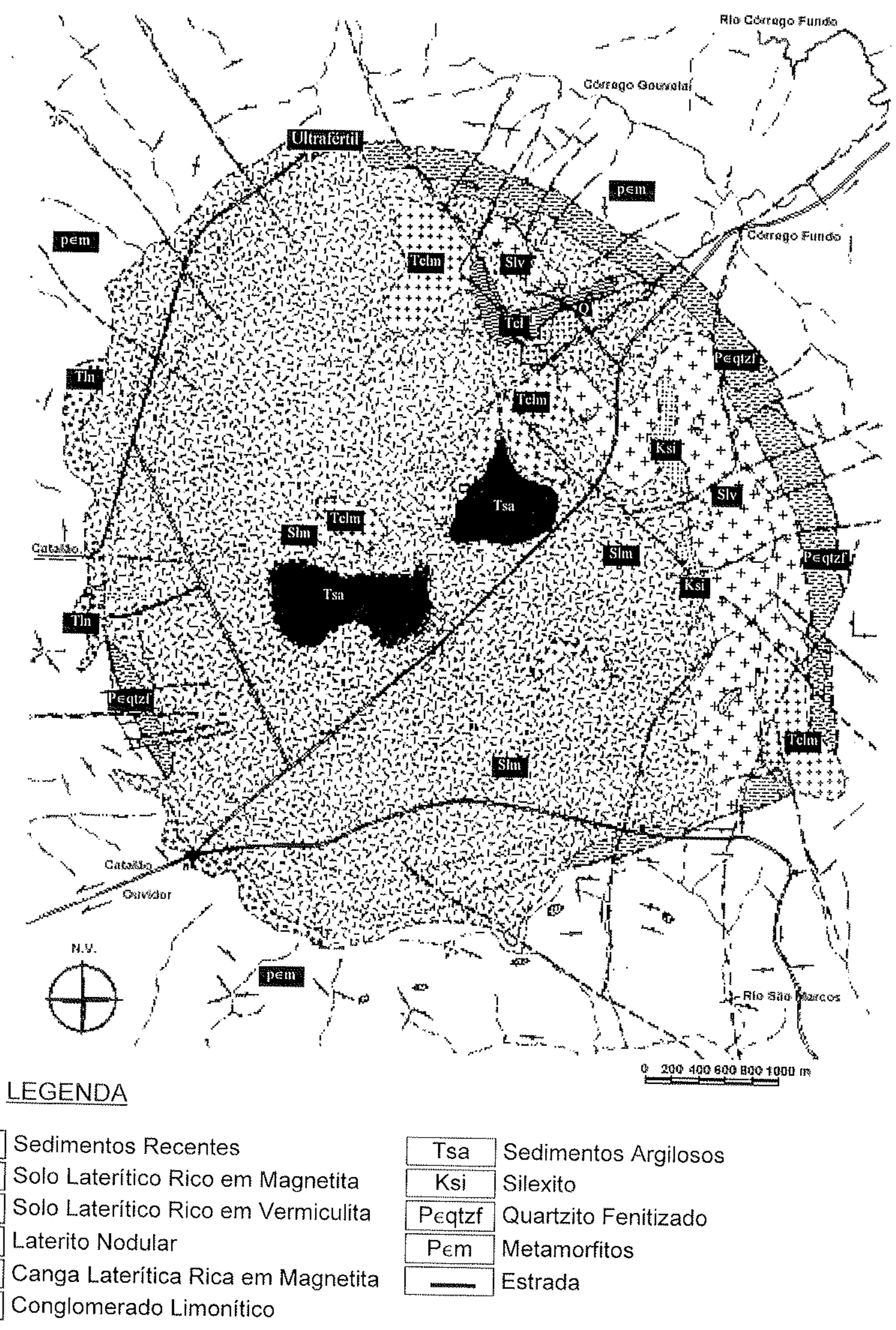

Figura 1.3- Mapa geológico de Catalão I (DNPM/CVRD 1986). 


\section{Mineralogia}

O primeiro estudo mais sistemático da mineralogia de Catalão I é de Valarelli (1971), que descreveu a mineralogia de diversas amostras de minério de Nb, Ti e ETR de superfície/sub-superfície em detalhe.

Uma fase que chamou de "titano-magnetita" foi identificada como sendo magnetita com exsoluções de ilmenita, em cristais idiomórficos de 1 a $2 \mathrm{~mm}$ (chegando a $2 \mathrm{~cm}$ na superfície), apesar de serem freqüentemente arredondados, quebrados ou corroidos. Observou que a oxidação do Fe II a Fe III na magnetita promove a sua transformação pseudomórfica para maghemita e migração do $\mathrm{Ti}$ para fissuras decorrentes da contraçäo do retículo, formando o que chamou de leucoxênio (anatásio microcristalino, mal cristalizado e com impurezas das outras fases de Fe e Fe/Ti). A maghemita tende a recristalizar para hematita, de maneira que as associações finais são hematita + ilmenita ou hematita + anatásio.

A ilmenita ocorre principalmente como lamelas ou núcleos de exsolução nas magnetitas, ou ainda como cristais tabulares. A alteraçäo da ilmenita, ainda segundo Valarelli (1971), pode se dar pela hidrólise do Fe com conseqüente concentração do Ti, resultando na associação goethita + anatásio, ou pela oxidação do $\mathrm{Fe}^{2+}$, promovendo a "hematitização" da ilmenita, migração do Ti para fissuras decorrentes da contração do retículo e associação final hematita + anatásio. O produto final da alteração dos óxidos de Fe e Fe/Ti tende sempre a ser hematita e/ou goethita + anatásio.

A hematita de Catalão não é primária, sendo originada das transformações acima. A goethita, por outro lado, é sempre secundária, e aparece em formas 
diferentes, como concreções coloformes e irregulares, cimento de minerais e sua impregnação. Alguns milimétricos cubos de goethita, perfeitos e estriados, sugerem substituição pseudomórfica da pirita.

A perovskita é muito rara, mas observam-se cristais de anatásio que mantêm a sua forma. Além disso, núcleos de perovskita foram identificados em lâminas delgadas, envoltos em "leucoxênio" (anatásio). Apesar da identificação positiva da perovskita, inclusive por difração de raios $X$ e cálculo de seu $a_{0}$, a composição química de alguns concentrados de anatásio, com teores anômalos de ETR e $\mathrm{Nb}$, sugere a presença respectivamente de loparita-Ce e perovskita com $\mathrm{Nb}$ (antiga dysanalyta).

O leucoxênio designa agregados terrosos, de cor amarela, constituídos basicamente por anatásio, e com impurezas de ilmenita, hematita, goethita e material amorfo em quantidades irrisórias. O anatásio foi, em geral, identificado como anatásio normal e, excepcionalmente, como anatásio com $\mathrm{Nb}$.

Pelo menos três tipos de pirocloro foram identificados por Valarelli (1971): pirocloro vítreo transparente, amarelo claro a castanho, identificado como pirocioro normal (chamada de koppita, à época); pirocloro citrino escuro, semi-vítreo, transparente, possivelmente devido à substituição de $\mathrm{Nb}$ por $\mathrm{Fe}$ e $\mathrm{Ti}$. O bariopirocloro (chamado ainda de pandaíta) apresenta-se na cor creme ou cor de carne. Os diversos pirocloros ocorrem associados com freqüência, o que pode ser verificado pela duplicação ou triplicação de picos nos difratogramas. De maneira geral, Valarelli (1971) observou a substituição de pirocloro e da variedade citrino por bariopirocloro, uma vez que esse é mais abundante em superfície. A transformação dar-se-ia pela troca de Ca e $\mathrm{Na}$ por $\mathrm{Ba}$ e Sr, além da substituição de oxigênio por hidroxila, e têm como conseqüência direta tensões no retículo, aumento de friabilidade do bariopirocloro e tendência a se concentrar nas frações mais finas. 
Uma grande diversidade de fosfatos secundários foi identificada por Valarelli (1971). Foram descritos como geralmente terrosos e argilosos, formando concreções esféricas, agregados microcristalinos ou fibrosos e impregnando outros minerais. A florencita (sem especificar se é Ce, La ou Nd) é o principal deles, e por vezes se apresenta associada à goyazita. A svanbergita aparece como agregados esféricos, em zonas concêntricas de microcristais fibrosos de disposição radial.

Ainda segundo Valarelli (1971), rabdofânio (sem especificar se predomina Ce, La ou $\mathrm{Nd}$, e chamada de rabdofanita) é muito comum, de cor verde e abundante em cavidades no silexito. É observado como bastonetes ou placas minúsculas em formatos esferulíticos ou núcleos de estruturas em "ghosts", associadas à limonita. Os próprios bastonetes aparentemente são constituídos de agregados. O rabdofânio foi identificado unicamente por microscopia óptica (Valarelli, comunicação pessoal) e os espectros de difração de raios $X$ sempre identificam monazita. Outros fosfatos ainda identificados foram hinsdalita, osarizawaíta, monetita, lusungita (na verdade, goyazita), hidalgoíta e monazita (sem detalhamento se é de Ce, La ou Nd). Cristais bem formados de vivianita azul foram encontrados em argilas.

Apatita, quartzo e barita ainda foram descritos como fases comuns. Os parâmetros de cela unitária permitiram a Valarelli (1971) concluir que a apatita é uma carbonato-apatita (ou dahlita, que é uma carbonato-hidroxiapatita, pela nomenclatura atual), contendo ainda $\mathrm{Ce}, \mathrm{Sr}$ e $\mathrm{Ba}$. As micas tipo biotita, vermiculita e flogopita também são comuns, provavelmente como resíduos da rocha fresca. Os argilominerais tipo caolinita estão geralmente impregnados por óxidos/hidróxidos de Fe e/ou Ti e fosfatos. Outros filossilicatos identificados foram clorita e serpentina. 
Finalmente, ancilita, zircão, baddeleyita, tapiolita, parisita, ilmenorrutilo, pirofanita e columbita puderam ser também identificados, nem sempre de forma totalmente conclusiva.

Imbernon (1993), estudando o comportamento dos ETR em perfis de alteração, detectou um enriquecimento dos elementos da base até o topo do perfil, até a base da cobertura superficial, onde ocorre pequeno decréscimo. O seu material mais rico em ETR sempre foi silexítico (proveniente da área explorada para $\mathrm{Nb}$, apesar de destacar a semelhança com o silexito do Córrego do Garimpo), com teores entre 2,48 e 4,83\% de $\mathrm{TR}_{2} \mathrm{O}_{3}$, identificando basicamente quartzo e monazita, além de apatita bem formada, óxidos de Ba e Mn (provavelmente da família da criptomelana) e óxidos de $\mathrm{Mn}$, Ba e ETR, morfologicamente descritos como "bolinhas" e "repolhos". Pirocloro, apesar de não explicitamente descrito como mineral identificado, é arrolado para explicar características geoquímicas da rocha. Uma análise dos ETR de monazita purificada manualmente está representada na Tabela 2.1 .

Tabela 2.1. Análise dos ETR de monazita purificada manualmente, segundo Imbernon (1993) (\% massa).

\begin{tabular}{lc} 
& monazita (Imbernon 1993) \\
\hline $\mathrm{La}_{2} \mathrm{O}_{3}$ & 21,70 \\
$\mathrm{CeO}_{2}$ & 22,53 \\
$\mathrm{Nd}_{2} \mathrm{O}_{3}$ & 3,60 \\
$\mathrm{Pr}_{6} \mathrm{O}_{11}$ & 1,98 \\
$\mathrm{Sm}_{2} \mathrm{O}_{3}$ & 0,26 \\
$\mathrm{Eu}_{2} \mathrm{O}_{3}$ & 0,032 \\
$\mathrm{Gd}_{2} \mathrm{O}_{3}$ & 0,192 \\
$\mathrm{Dy}_{2} \mathrm{O}_{3}$ & 0,032 \\
$\mathrm{Yb}_{2} \mathrm{O}_{3}$ & 0,0014 \\
$\mathrm{Y}_{2} \mathrm{O}_{3}$ & 0,28 \\
$\mathrm{Ho}_{2} \mathrm{O}_{3}$ & 0,0040 \\
$\mathrm{Er}_{2} \mathrm{O}_{3}$ & 0,0036 \\
$\mathrm{Lu}_{2} \mathrm{O}_{3}$ & 0,0002 \\
\hline $\mathrm{TR}_{2} \mathrm{O}_{3}$ & 50,55 \\
\hline
\end{tabular}


Além da monazita, a apatita pode ser um dos carreadores de ETR, com teores da ordem de $0,85 \%$ de $\mathrm{TR}_{2} \mathrm{O}_{3}$ (Imbernon et al. 1994), mas os autores ressaltam que apenas apatita não fecha balanço para o teor da amostra, apresentando carbonatos, barita, pirocloro e perovskita como outros possiveis carreadores.

As análises de dois concentrados de apatita (ambos por ICP) e de apatita proveniente de três horizontes mineralizados (análise por INAA) estão na Tabela 2.2.

Tabela 2.2. Análise dos ETR de apatita, segundo *Imbernon (1993) e **Dutra \& Formoso (1991) (ppm).

\begin{tabular}{lcccccc}
\hline (ppm) & $\begin{array}{c}\text { Concen. } \\
\text { apatita }\end{array}$ & $\begin{array}{c}\text { Concen. } \\
\text { apatita }\end{array}$ & $\begin{array}{c}\text { apatita, } \\
\text { horiz C3 }\end{array}$ & $\begin{array}{c}\text { apatita, } \\
\text { horiz C4 }\end{array}$ & $\begin{array}{c}\text { apatita, } \\
\text { horiz C5 }\end{array}$ & Média \\
\hline La & 1484 & 1588 & 2259 & 1766 & 1297 & $\mathbf{1 6 7 8 , 8}$ \\
$\mathrm{Ce}$ & 3688 & 1770 & 4181 & 3594 & 2848 & $\mathbf{3 2 1 6 , 2}$ \\
$\mathrm{Nd}$ & 1660 & 1780 & 1888 & 1548 & 1586 & 1692,4 \\
$\mathrm{Sm}$ & 208,9 & 228,6 & 268 & 200 & 178 & $\mathbf{2 1 6 , 7}$ \\
$\mathrm{Eu}$ & 40,4 & 46,57 & 71 & 53 & 47 & $\mathbf{5 1 , 5 9 4}$ \\
$\mathrm{Gd}$ & 107,9 & 108,3 & - & - & - & 108,1 \\
$\mathrm{Dy}$ & 42 & 43 & - & - & - & $\mathbf{4 2 , 5}$ \\
$\mathrm{Ho}$ & 7,1 & 6,4 & - & - & - & 6,75 \\
$\mathrm{Er}$ & 13,1 & 11,2 & - & - & - & $\mathbf{1 2 , 1 5}$ \\
$\mathrm{Yb}$ & 4 & 3,11 & 9,7 & 6,7 & 11,6 & 7,022 \\
$\mathrm{Lu}$ & 0,5 & 0,34 & 1,15 & - & 0,93 & $\mathbf{0 , 4 9 7 5}$ \\
\hline$\Sigma$ & $\mathbf{7 2 5 5 , 9}$ & 5585,52 & 8677,85 & 7167,7 & 5968,53 & $\mathbf{7 0 3 2 , 7 1}$ \\
\hline
\end{tabular}

A apatita, segundo Imbernon (1993), é sempre primárias não tendo sido observada apatita secundária.

Já Lenharo (1994), num exaustivo estudo das apatitas inclusive de Catalão I, estimou que entre $15 \%$ e $95 \%$ (dependendo da amostra) da apatita é secundária (classificável ainda em prismática hexagonal, microcristalina e criptocristalina). Pelas dimensões de seus eixos cristalográficos e pela composição, a apatita primária foi identificada como hidróxi-fluorapatita rica em estrôncio, e a secundária é uma carbonato-fluorapatita. O teor de elementos de terras raras total, medido em oito 
concentrados de apatita, varia de 2932 a 9920 ppm, com média aritmética de 6629 ppm, estando, portanto, em excelente concordância com os dados anteriores.

Pereira (1995), por outro lado, identificou pelo menos três gerações distintas de apatita, nominalmente: associadas aos foscoritos, associadas ao carbonatito sövitico e os veios apatíticos responsáveis pela mineralização de fosfato a nível econômico. A apatita de Catalão tem densidade calculada (a partir de dados cristalográficos) variando de 3,20 a 3,24. Há correlação negativa entre Sr e as terras raras, e positiva entre essas e Na. Análises químicas pontuais (28 análises), por microssonda eletrônica, revelaram teores de $\mathrm{Ce}_{2} \mathrm{O}_{3}$ e $\mathrm{La}_{2} \mathrm{O}_{3}$ médios de, respectivamente, $0,370 \%$ (0 a 1,770\%) e $0,186 \%$ (0 a $0,406 \%)$. O teor de Sr também é elevado, pelos dados de Pereira (1995), com média de $1,145 \%$ de SrO $(0,004$ a 3,240\%). Análises de ETR individuais de concentrados de apatita (ICP) estão na Tabela 2.3.

Tabela 2.3- Análises dos ETR em apatita, segundo Pereira (1995) (ppm).

\begin{tabular}{lcccccccccc}
\hline (ppm) & PS1 & PS2 & SFB* & A41 & $3-$ & GF5 & $6-$ & GF7 & CS & Média \\
\hline La & 382 & 973 & 2558 & 1490 & 2606 & 1982 & 2145 & 2063 & 1076 & 1697 \\
Ce & 606 & 2280 & 5516 & 3924 & 5874 & 4998 & 5022 & 4618 & 1897 & $\mathbf{3 8 5 9}$ \\
$\mathrm{Nd}$ & 387 & 1204 & 2401 & 1870 & 1780 & 2531 & 2580 & 2032 & 1323 & $\mathbf{1 7 9 0}$ \\
$\mathrm{Sm}$ & 43,5 & 158 & 290 & 229 & 191,5 & 296 & 320 & 238 & 179 & $\mathbf{2 1 6 , 1}$ \\
$\mathrm{Eu}$ & 9,46 & 29,2 & 55,3 & 47,5 & 32,7 & 57,3 & 67 & 47,2 & 38,8 & $\mathbf{4 2 , 7}$ \\
$\mathrm{Gd}$ & 21,9 & 75,3 & 149 & 135 & 84 & 147 & 186 & 130 & 100 & $\mathbf{1 1 4 , 2}$ \\
$\mathrm{Dy}$ & 9,99 & 34,5 & 51,9 & 64,2 & 32,3 & 50,9 & 76,6 & 51,2 & 44,2 & $\mathbf{4 6 , 2}$ \\
$\mathrm{Ho}$ & 1,48 & 5,84 & 7,21 & 8,7 & 4,3 & 6,51 & 13 & 8,73 & 5,81 & $\mathbf{6 , 8 4}$ \\
$\mathrm{Er}$ & 2,41 & 10,4 & 12,7 & 16,5 & 8,4 & 10,9 & 23,1 & 15,9 & 9,01 & $\mathbf{1 2 , 1 5}$ \\
$\mathrm{Yb}$ & 1,02 & 3,45 & 4,2 & 5,13 & 3 & 2,8 & 5,46 & 3,86 & 2,74 & $\mathbf{3 , 5 2}$ \\
$\mathrm{Lu}$ & 0,133 & 0,36 & 0,469 & 0,594 & 0,496 & 0,36 & 0,63 & 0,503 & 0,28 & $\mathbf{0 , 4 2 5}$ \\
\hline$\Sigma$ & 1465 & 4774 & 11046 & 7791 & 10617 & 10083 & 10439 & 9208 & 4676 & $\mathbf{7 7 8 9}$ \\
\hline "ou A33, uma vez que o mesmo resultado é apresentado para ambas & & & & & &
\end{tabular}

Os valores apresentados por Pereira (1995) são totalmente coerentes com as análises apresentadas por outros autores, tanto os de análises pontuais quanto os dos concentrados. A comparação das análises pontuais e das análises dos concentrados, inclusive das referências citadas anteriormente, permite uma extrapolação que todos os 
ETR detectados nos concentrados de apatita, por análise da amostra total, estão contidos nesse mineral, apesar dos dados, principalmente de química mineral, provavelmente serem insuficientes do ponto de vista estatistico.

O primeiro estudo de caracterização mineralógica em amostras de minério de terras raras silexítico foi publicado por Neumann et al. (1994). A análise química da head sample do minério silexítico apresentou um teor em óxidos de terras raras totais superior a $10 \%$ (Tabela 2.4). Os óxidos de terras raras leves predominam largamente, e CeO representa cerca da metade desse total (Tabela 2.5). Tabela 2.4- Análise química (\% em massa) do minério silexítico, segundo Neumann et
al (1994).

\begin{tabular}{cc}
\hline $\mathrm{SiO}_{2}$ & 68,4 \\
$\mathrm{TiO}_{2}$ & $<0,30$ \\
$\mathrm{Al}_{2} \mathrm{O}_{3}$ & 0,30 \\
$\mathrm{Fe}_{2} \mathrm{O}_{3} \mathrm{t}$ & 9,2 \\
$\mathrm{MnO}$ & 0,96 \\
$\mathrm{MgO}$ & 0,12 \\
\hline
\end{tabular}

\begin{tabular}{cc}
$\mathrm{CaO}$ & 1,5 \\
$\mathrm{Na}_{2} \mathrm{O}$ & 0,06 \\
$\mathrm{~K}_{2} \mathrm{O}$ & 0,10 \\
$\mathrm{P}_{2} \mathrm{O}_{5}$ & 5,5 \\
$\mathrm{TR}_{2} \mathrm{O}_{3}$ & 10,8 \\
P.F. & 1,1 \\
\hline
\end{tabular}

Tabela 2.5. Distribuição dos elementos terras raras, tório e urânio (\% em massa) no minério silexítico, segundo Neumann et al. (1994).

\begin{tabular}{cc}
$\mathrm{La}_{2} \mathrm{O}_{3}$ & 3,7 \\
$\mathrm{CeO}_{2}$ & 6,2 \\
$\mathrm{Pr}_{6} \mathrm{O}_{11}$ & 0,72 \\
$\mathrm{Nd}_{2} \mathrm{O}_{3}$ & 2,2 \\
$\mathrm{Sm}_{2} \mathrm{O}_{3}$ & 0,15 \\
\hline
\end{tabular}

\begin{tabular}{lc}
\hline $\mathrm{Eu}_{2} \mathrm{O}_{3}$ & 0,02 \\
$\mathrm{Gd}_{2} \mathrm{O}_{3}$ & 0,05 \\
$\mathrm{Dy}_{2} \mathrm{O}_{3}$ & 0,009 \\
$\mathrm{ThO}_{2}$ & 0,004 \\
$\mathrm{U}_{3} \mathrm{O}_{8}$ & 0,008 \\
\hline
\end{tabular}

Os autores concluiram que o minério silexítico é composto por quartzo $(70 \%)$, monazita (18\%), goethita, hematita e magnetita (total de $11 \%$ ) e pirrotita. O único carreador importante de ETR identificado no minério é a monazita, que se apresenta como agregados esferoidais de aproximadamente $10 \mu \mathrm{m}$ de diâmetro, disseminados na matriz de quartzo fina. Como conseqüência, a liberação da monazita é extremamente 
limitada, e por volta de $60 \%$ de quartzo é encontrado em produtos afundado em líquidos densos em qualquer granulometria, até $37 \mu \mathrm{m}$. Por fim, Neumann et al (1994) concluem que a péssima liberação da monazita em relação ao quartzo, assim como o alto consumo de energia e de meio moedor que se infere seja necessário para a cominuição de um minério de matriz dura como é o silexito, permitem prever a inviabilidade da concentração física ou físico-química em condições economicamente viáveis.

Os únicos fosfatos de terras raras identificados por Pereira (1995) em Catalão I pertencem ao grupo da plumbogumita, identificados por difração de raios $X$. Na maior parte das amostras, o autor não conseguiu identificar o mineral, mas em algumas foi possivel reconhecer gorceixita. As imagens de microscopia eletrônica de varredura (aparentemente de eletrons retro-espalhados) desses fosfatos supostamente secundários, identificados em amostras de rochas chamadas de silicito pelo autor, mostra uma semelhança muito grande com os esferóides de monazita identificados no silexito objeto do presente estudo, apesar de sua origem ser geograficamente distinta, não sendo originários da região do Córrego do Garimpo. Algumas análises pontuais por EDS e por WDS, além de uma análise por fluorescência de raios $X$ de concentrado do fosfato supostamente secundário, permitiram ao autor concluir que se trata de um termo intermediário entre florencita, gorceixita e goyazita, mais comumente entre os dois primeiros (apesar do autor se confundir e chamar o termo rico em Ba de goyazita). As análises estão, à medida do possivel, apresentadas na Tabela 2.6. São análises obtidas por dispersão de energia, à exceção das marcadas com *, análises de WDS obtidas em microssonda. 
Tabela 2.6- Análises quimicas pontuais (EDS ou WDS, quando marcada com *) (\% em massa) de fosfatos secundários, segundo Pereira (1995).

\begin{tabular}{|c|c|c|c|c|c|c|c|c|c|}
\hline & SFB1 & SFB2 & SFB3 & SFB4 & SFB5 & SFB6 & SFB7 & SFB8 & SFB9 \\
\hline $\mathrm{SiO}_{2}$ & 0 & 0 & 0 & 0 & 32,4 & 18,7 & 26,1 & 0 & 0 \\
\hline $\mathrm{Al}_{2} \mathrm{O}_{3}$ & 0 & 0 & 8,39 & 4,75 & 3,75 & 0 & 0 & 0 & 12,6 \\
\hline $\mathrm{P}_{2} \mathrm{O}_{5}$ & 49,1 & 47,8 & 61,3 & 44,1 & 30,9 & 30,6 & 46,7 & 54,4 & 25,1 \\
\hline $\mathrm{Na}_{2} \mathrm{O}$ & 0 & 0 & 0 & 0 & 0 & 33,1 & 0 & 0 & \\
\hline $\mathrm{CaO}$ & 34,3 & 2,17 & 2,67 & 3,28 & 2,14 & 1,58 & 2,47 & 3,29 & 1,62 \\
\hline SrO & 12,2 & 0 & 0 & 0 & 0 & 0 & 0 & 12,6 & 5.66 \\
\hline $\mathrm{La}_{2} \mathrm{O}_{3}$ & 0 & 14,90 & 12,5 & 20,8 & 13,3 & 7,03 & 10,9 & 12,9 & \\
\hline $\mathrm{Ce}_{2} \mathrm{O}_{3}$ & 2,33 & 35 & 15,1 & 27,1 & 17,4 & 8,98 & 13,8 & 16,9 & \\
\hline $\mathrm{BaO}$ & & & & & & & & & 0 \\
\hline $\mathrm{K}_{2} \mathrm{O}$ & & & & & & & & & 0 \\
\hline $\mathrm{TiO}_{2}$ & & & & & & & & & 0 \\
\hline $\mathrm{Fe}_{2} \mathrm{O}_{3}$ & & & & & & & & & 52 \\
\hline $\mathrm{Nb}_{2} \mathrm{O}_{5}$ & & & & & & & & & 0 \\
\hline $\mathrm{SO}_{3}$ & & & & & & & & & 0 \\
\hline Total & 99,93 & 99.87 & 99,96 & 100,03 & 99.89 & 99.99 & 99.97 & 10009 & $\begin{array}{c}3,01 \\
9999\end{array}$ \\
\hline
\end{tabular}

\begin{tabular}{lccccccccc}
\hline & $\mathrm{SFB10}$ & $2 \mathrm{~A}$ & $2 \mathrm{~B}$ & $\mathrm{C} 5.1$ & $\mathrm{C} 5.2$ & $\mathrm{C} 5.3$ & $\mathrm{SFB69}^{*}$ & $\mathrm{SFB71}^{*}$ & $\mathrm{SFB73}^{*}$ \\
\hline $\mathrm{SiO}_{2}$ & 12,4 & 33,4 & 0 & 0 & 0 & 0 & 5,33 & 44,6 & 28,9 \\
$\mathrm{Al}_{2} \mathrm{O}_{3}$ & 16,6 & 36,5 & 0 & 38 & 37,7 & 34,3 & 1 & 1,47 & 1,58 \\
$\mathrm{P}_{2} \mathrm{O}_{5}$ & 26 & 26,9 & 19,5 & 35,9 & 35,6 & 35,7 & 16,7 & 11,2 & 17,1 \\
$\mathrm{Na}_{2} \mathrm{O}$ & & & & & & & 0,181 & 0,321 & 0,352 \\
$\mathrm{CaO}$ & 1,23 & 0 & 0 & 0,52 & 0 & 1,34 & 2,45 & 1,48 & 1,82 \\
$\mathrm{SrO}$ & 0 & 0 & 11,3 & 9,38 & 9,77 & 12,5 & 2,1 & 1,12 & 1,32 \\
$\mathrm{La}_{2} \mathrm{O}_{3}$ & & & & & & & 16,3 & 8,83 & 13 \\
$\mathrm{Ce}_{2} \mathrm{O}_{3}$ & & & & & & & 21 & 12,5 & 16 \\
$\mathrm{BaO}$ & 0 & 0 & 0 & 10,6 & 0 & 0 & & & \\
$\mathrm{~K}_{2} \mathrm{O}$ & 0 & 0 & 5,65 & 0 & 0 & 0 & & & \\
$\mathrm{TiO}_{2}$ & 0 & 2,37 & 1,23 & 0,65 & 3,1 & 3,44 & & & \\
$\mathrm{Fe}_{2} \mathrm{O}_{3}$ & 43,8 & 0,84 & 28,8 & 0 & 0 & 0 & 0,043 & 0,158 & 0,252 \\
$\mathrm{Nb}_{2} \mathrm{O}_{5}$ & 0 & 0 & 0 & 4,92 & 13,8 & 12,8 & & & \\
$\mathrm{H}_{2} \mathrm{O}$ & & & & & & & 0,281 & 0,612 & 0,87 \\
$\mathrm{~F}$ & & & & & & & 1,07 & 0,196 & 0,394 \\
$\mathrm{SO}_{3}$ & 0 & 0 & 33.5 & 0 & 0 & 0 & & & \\
$\mathrm{Cl}^{\text {Total }}$ & 0 & 0 & 0 & 0 & 0 & 0 & 0,31 & 0,196 & 0,394 \\
\hline
\end{tabular}

É muito provável que as análises da Tabela 2.6 representem, na verdade, análises de diferentes fases minerais que foram confundidas; os próprios números revelam grande heterogeneidade, o que pode, tentativamente, ser interpretado como um problema de diâmetro do feixe de elétrons utilizado para obter as excitações, superior às dimensões dos cristais observados. Esse problema é obviamente 
infinitamente maior no caso das análises químicas de concentrados. Como os dados estão sendo apresentados para avaliação e comparação posterior, no entanto, as Tabelas 2.7 e 2.8 apresentam os resultados obtidos por Pereira (1995) para uma análise por fluorescência de raios $X$ de um concentrado de fosfatos secundários e de duas análises de ETR por ICP desses concentrados.

Tabela 2.7- Análise química (\% em massa, FRX) de concentrado de fosfato secundário ("plumbogummitas"), segundo Pereira (1995).

\begin{tabular}{cc}
\hline $\mathrm{SiO}_{2}$ & 12 \\
$\mathrm{TiO}_{2}$ & 0,13 \\
$\mathrm{Al}_{2} \mathrm{O}_{3}$ & 3,5 \\
$\mathrm{Fe}_{2} \mathrm{O}_{3} \mathrm{t}$ & 21 \\
$\mathrm{MnO}$ & 6,5 \\
$\mathrm{MgO}$ & 1,3 \\
$\mathrm{P}_{2} \mathrm{O}_{5}$ & 15 \\
$\mathrm{SrO}$ & 2 \\
$\mathrm{BaO}$ & 10 \\
$\mathrm{ZrO}$ & 0,04 \\
$\mathrm{Nb}_{2} \mathrm{O}_{5}$ & 0,19 \\
$\mathrm{CO}_{2} \mathrm{O}_{3}$ & 0,018 \\
\hline
\end{tabular}

\begin{tabular}{cc}
\hline $\mathrm{ZnO}$ & 0,23 \\
$\mathrm{NiO}$ & 0,044 \\
$\mathrm{SnO}_{2}$ & 0,027 \\
$\mathrm{Y}_{2} \mathrm{O}_{3}$ & 0,023 \\
$\mathrm{La}_{2} \mathrm{O}_{3}$ & 9,9 \\
$\mathrm{Ce}_{2} \mathrm{O}_{3}$ & 13 \\
$\mathrm{Pr}_{6} \mathrm{O}_{11}$ & 0,87 \\
$\mathrm{Nd}_{2} \mathrm{O}_{3}$ & 2,6 \\
$\mathrm{Sm}_{2} \mathrm{O}_{3}$ & 0,13 \\
$\mathrm{U}_{3} \mathrm{O}_{8}$ & 0,011 \\
$\mathrm{PbO}$ & 0,42 \\
Total & 98,933 \\
\hline
\end{tabular}

Tabela 2.8- Análise química dos ETR (ppm, ICP-AES) de concentrado de fosfato secundário ("plumbogummitas"), segundo Pereira (1995).

\begin{tabular}{lcc}
\hline $\mathrm{La}$ & 208.585 & 249.427 \\
$\mathrm{Ce}$ & 169.343 & 199.051 \\
$\mathrm{Nd}$ & 10.363 & 57.085 \\
$\mathrm{Sm}$ & 7.838 & 10.136 \\
$\mathrm{Eu}$ & 3.378 & 3.661 \\
$\mathrm{Gd}$ & 3.232 & 4.429 \\
$\mathrm{Dy}$ & 1.093 & 1.449 \\
$\mathrm{Yb}$ & 72,6 & 105 \\
$\mathrm{Ho}$ & 679 & 938 \\
$\mathrm{Er}$ & 324 & 423 \\
$\mathrm{Lu}$ & 52 & 83,1 \\
\hline $\mathrm{\Sigma ETR}$ & $403.959,6$ & $526.787,1$ \\
\hline
\end{tabular}

Entre os outros minerais contendo ETR estudados em maior ou menor detalhe por Pereira (1995), podem ser citados ainda pirocloro, niobozirconolita, perovskita e 
anatásio. O teor médio de 43 análises pontuais por WDS em pirocloro revelou uma média de $1,17 \%$ de $\mathrm{Ce}_{2} \mathrm{O}_{3}$, variando entre 0 e $4 \%$ ), mas os outros ETR não foram analisados. A niobozirconolita também foi estudada pelo mesmo autor, e o conteúdo médio da soma dos óxidos de La, Nd e Ce é de $6,62 \%$, variando de 3,6 a $8,8 \%$ (9 análises). A perovskita é outro importante carreador dos ETR, com teor de $\mathrm{Ce}_{2} \mathrm{O}_{3}$ variando de 4,23 a $5,08 \%$, média de 6 análises de 4,54\%. A ilmenita contém poucas terras raras, duas análises resultam em $\mathrm{Ce}_{2} \mathrm{O}_{3}$ inferior a $0,1 \%$, mas duas análises de anatásio revelam 6,26 e $5,17 \%$ do óxido, sendo o mineral, portanto, um dos carreadores dos elementos de terras raras mais importante.

Sant'Agostino (1996) desenvolveu extenso trabalho de caracterização tecnológica no minério de $\mathrm{Nb}$ de Catalăo, mais especificamente nas reservas pertencentes à Ultrafértil (antiga Goiasfértil) e, portanto, mais próximas à área mineralizada em terras raras. Dentre os fosfatos, concluiu que predominam gorceixita e monazita, essas com bimodalidade, restritas a Ce e La ou contendo também $\mathrm{Nd}$ e Pr. Além disso, apatita assume importância crescente com o aumento da profundidade, e com composição variando de hidroxi-apatita a fluorapatita. Dentre os minerais de $\mathrm{Ti}$ identificados, apenas ilmenita e anatásio são importantes, mas ocorrem ainda ilmenorutilo, pseudo-rutilo, perovskita, titanita e priderita.

Os filossilicatos mais importantes descritos pela autora são flogopita, vermiculita e hidromica, em geral interestratificada e ocorrendo na forma de agregados criptocristalinos impregnados por óxidos de Fe. Cloritas (lizardita e clinocloro) também ocorrem associadas. Quartzo está presente tanto na forma de cristais bem desenvolvidos, quanto na versão mais rara de agregados criptocristalinos intensamente impregnados por óxidos de Fe. 
Os minerais de Fe observados por Sant'Agostino (1996) são magnetita, hematita, maghemita, goethita e óxido/hidróxido amorfo ou mal cristalizado (limonita). Conforme observado anteriormente por Valarelli (1971), a magnetita é titanífera e ocorre com freqüentes exsoluçōes de ilmenita. A goethita predomina entre os demais óxidos. A identificação dos minerais de $\mathrm{Nb}$ acompanhou as observações de Valarelli (1971), identificando uma forma cálcica (chamada, em 1971, de koppita) que constitui o pirocloro propriamente dito, e bariopirocloro de coloração amarelada. As variedades podem estar interligadas, com pirocloro como núcleo de aglomerados com bariopirocloro ao redor. O bariopirocloro geralmente se apresenta micro- a criptocristalino, em agregados de friabilidade variada, o que causa uma tendência do mineral a se concentrar nos finos, durante o processamento. Além da variabilidade na sua composição, os pirocloros aparecem não-liberados de uma grande quantidade de outras fases, como apatita, ilmenita, gorceixita, argilominerais e limonita.

Subordinadamente, foram ainda descritos barita, dolomita, pirita, zircão, baddeleyita, calzirtita e zirconolita (podendo conter ou não algum $\mathrm{Nb}$, por volta de $2,5 \%$ $\mathrm{Nb}_{2} \mathrm{O}_{5}$

Os minerais carreadores de ETR em amostras encontradas em diferentes horizontes do perfil laterítico em Catalão I e Araxá foram estudados com certo detalhe por Morteani \& Preinfalk (1996). Em ambos os casos, os carreadores na rocha alcalina original são apatita e carbonato. Em Catalão I, o teor médio encontrado em calcita foi de $936 \mathrm{ppm}$, e na apatita foi de $6.973 \mathrm{ppm}$ (o valor provavelmente foi trocado com o de Araxá, no trabalho publicado). Essa análise está em excelente concordância com os apresentados anteriormente. Durante a laterização, calcita e depois apatita são dissolvidas, liberando as terras raras que são incorporadas por outras fases. No estágio saprolítico da alteração, forma-se apatita secundária com teores mais elevados de 
ETR, chegando a quase $5 \%$ do seu óxido, provavelmente, segundo os autores, devido à liberação das terras raras oriundas dos carbonatos, e que substituem Ca na apatita. O balanço de cargas na estrutura desses minerais deve ser proporcionado pela substituição de grupos aniônicos $\mathrm{PO}_{4}^{3-}$ por $\mathrm{CO}_{3}{ }^{2-}$, uma vez que a típica substituição de cálcio por sódio não pôde ser verificada nas análises por microssonda. Nos horizontes lateríticos s.s. não foi encontrada apatita, e o carreador dos ETR é inferido como sendo gorceixita.

Nos silexitos (o termo é questionado, e são denominados de silcretes), por outro lado, Morteani \& Preinfalk (1996) determinaram somente monazita em agregados concêntricos como carreadores dos ETR, apesar de sugerirem camadas externas de cerianita, nos agregados, a partir de seus dados qualitativos de MEV/EDS.

Por fim, os mesmos autores ainda sugerem que parte dos ETR (variando de $8 \%$ do $\mathrm{Nd}$ a $23 \%$ do $\mathrm{Ce}$ ) pode estar nos óxidos/hidróxidos de $\mathrm{Fe}$, mas infelizmente as análises das soluções com as quais os óxidos/hidróxidos amorfos foram lixiviados, e que originam esses dados, referem-se a Araxá, e não especificamente a Catalão, para os quais a conclusão é apenas extrapolada.

No relatório apresentado por Aquino \& Albuquerque (1996) encontra-se um estudo de caracterização mineralógica e liberação no minério laterítico de Catalão, através de microscopia óptica em lâminas delgadas, assinado por R.L.L. Murta. A composição química do minério está na Tabela 2.9. 
Tabela 2.9- Análise química (\% em massa) do minério laterítico, segundo Aquino \& Albuquerque (1996).

\begin{tabular}{cccc}
\hline $\mathrm{SiO}_{2}$ & 12,40 & $\mathrm{La}_{2} \mathrm{O}_{3}$ & 2,40 \\
$\mathrm{TiO}_{2}$ & 9,60 & $\mathrm{CeO}_{2}$ & 4,80 \\
$\mathrm{Al}_{2} \mathrm{O}_{3}$ & 3,61 & $\mathrm{Nd}_{2} \mathrm{O}_{3}$ & 1,80 \\
$\mathrm{Fe}_{2} \mathrm{O}_{3} \mathrm{t}$ & 26,50 & $\mathrm{Pr}_{6} \mathrm{O}_{11}$ & 0,53 \\
$\mathrm{CaO}$ & 10,20 & $\mathrm{Sm}_{2} \mathrm{O}_{3}$ & 0,13 \\
$\mathrm{P}_{2} \mathrm{O}_{5}$ & 10,40 & $\mathrm{Eu}_{2} \mathrm{O}_{3}$ & 0,03 \\
$\mathrm{BaSO}_{4}$ & 2,80 & $\mathrm{Gd}_{2} \mathrm{O}_{3}$ & 0,05 \\
$\mathrm{ThO}_{2}$ & $<0,01$ & $\mathrm{~Tb}_{4} \mathrm{O}_{7}$ & 0,09 \\
$\mathrm{U}_{3} \mathrm{O}_{8}$ & $<0,01$ & $\mathrm{Dy}_{2} \mathrm{O}_{3}$ & 0,03 \\
$\mathrm{Y}_{2} \mathrm{O}_{3}$ & 0,04 & $\mathrm{Ho}_{2} \mathrm{O}_{3}$ & $<0,012$ \\
$\Sigma \mathrm{OTR}$ & 9,90 & $\mathrm{Er}_{2} \mathrm{O}_{3}$ & $<0,015$ \\
\hline
\end{tabular}

A Tabela 2.10 apresenta a quantificação das fases minerais em três frações granulométricas obtidas num underflow de deslamagem do minério, e separadas em cyclosizer. O pesquisador alerta que o tamanho efetivo das partículas varia muito, estando parte abaixo do limite da metodologia utilizada, e parte muitas vezes maior do que o esperado para a fração.

Tabela 2.10- Composição mineralógica (\% em massa) de frações classificadas por tamanho do minério laterítico, segundo Aquino \& Albuquerque (1996).

\begin{tabular}{lccc}
\hline Mineral & $+34,8 \mu \mathrm{m}$ & $-34,8+25,8 \mu \mathrm{m}$ & $-25,8+17,7 \mu \mathrm{m}$ \\
\hline Monazita & 11,0 & 13,5 & 16,0 \\
Apatita & 7,5 & 5,5 & 4,0 \\
Quartzo & 9,5 & 9,0 & 6,0 \\
Limonita+goethita & 9,5 & 24,0 & 25,0 \\
Micas & 5,5 & 7,0 & 3,0 \\
Opacos & 53,0 & 38,0 & 43,0 \\
Outros* & 4,0 & 3,0 & 3,0 \\
\hline \multicolumn{2}{c}{ ^Outros: Gorceixita, goyazita, zircão, anatásio e anfibólios alterados }
\end{tabular}

O grau de liberaçâo dos diferentes minerais também foi avaliado por Aquino \& Albuquerque (1996), e está reproduzido na Tabela 2.11. Os autores destacam progressão da liberação da monazita, que passa de 31,0\% na fração mais grossa para 76,0 e $79,0 \%$ nas frações mais finas, e que se explica pelas associações da monazita com os compostos de Fe. Todos os minerais, à exceção dos opacos, tem 
comportamento similar, ou seja, maior liberação em faixas granulométricas mais finas, apesar dos opacos estarem menos liberados na faixa intermediária. Felizmente os autores também destacam que os resultados tem valor relativo pelas limitações metodológicas, sugerindo faixas granulométricas mais estreitas e controle químico para dar melhor embasamento às conclusões.

Tabela 2.11- Grau de liberação (\% em massa) do minério laterítico, segundo Aquino \& Albuquerque (1996).

\begin{tabular}{lccc}
\hline Mineral & $+34,8 \mu \mathrm{m}$ & $-\mathbf{3 4 , 8 + 2 5 , 8 \mu \mathrm { m }}$ & $-\mathbf{2 5 , 8 + 1 7 , 7 \mu \mathrm { m }}$ \\
\hline Monazita & 31,0 & 76,0 & 79,0 \\
Apatita & 66,0 & 95,0 & 98,0 \\
Quartzo & 81,0 & 92,0 & 100,0 \\
Limonita+goethita & 46,0 & 93,0 & 96,0 \\
Micas & 77,0 & 95,0 & 100,0 \\
Opacos & 91,0 & 87,0 & 98,0 \\
\hline
\end{tabular}

Vieira et al. (1998) apresentaram uma caracterização mineralógica do minério, com teor de $6,8 \%$ de OTR. A mineralogia do minério foi determinada como sendo quartzo, magnetita, ilmenita, goethita, monazita, apatita e gorceixita. Outros minerais detectados foram: hematita, flogopita, fluorapatita, vermiculita, bariopirocloro, anatásio, titanita, zircão e barita, todos recobertos por camadas ferruginosas devidas à laterização. O único mineral carreador de terras-raras importante identificado foi a monazita, que pode estar liberada ou fina intercrescida com óxidos e hidróxidos de Fe, quartzo, apatita e ilmenita.

\section{Concentração e Metalurgia Extrativa dos ETR}

Os trabalhos de desenvolvimento de rotas de beneficiamento e/ou extração das ETR nos minérios de Catalão são poucos, e alguns têm seu acesso restrito. Um importante relatório sobre ensaios de metalurgia extrativa diretamente sobre o minério 
laterítico, executado pelo CDTN/CNEN para a Ultrafértil, por exemplo, apesar de prometido pela empresa, nunca foi recebido.

\section{Minério silexitico}

Borges et al. (1995) desenvolveram ensaios em bancada com o minério silexítico. Os testes envolveram ensaios de moagem (para atingir $P_{95}=105 \mu \mathrm{m}$ ) em moinhos de barras ao natural ou após choque térmico (aquecimento a $900^{\circ} \mathrm{C}$ e resfriamento brusco em água), visando fraturar a matriz de quartzo e facilitar a sua moagem. Foram efetuados também testes de separação magnética e de flotação convencional.

Os autores determinaram um tempo de moagem razoavelmente inferior para o minério tratado termicamente, 7,0 minutos contra 10,9 obtido para o minério ao natural, nas mesmas condições experimentais. Não concluíram, no entanto, se o processo é economicamente vantajoso. Testes preliminares de separação magnética, a úmido e a seco, não produziram resultados relevantes.

O melhor teste de flotação utilizando apenas uma etapa rougher gerou um concentrado com teor de OTR total de $14,82 \%$, correspondendo a uma recuperação de $75,25 \%$ dos ETR alimentados, e com descarte de $47,43 \%$ da massa. Não foi recuperado $24,75 \%$ das terras raras, num rejeito com teor de $5,40 \%$ de OTR. O teor de Fe permaneceu aproximadamente constante no concentrado, 5,3\%, representando $57,55 \%$ de recuperação nos mesmos $52,57 \%$ de massa. Adotando também uma etapa de scavenger e três de limpeza (cleaner), a recuperação caiu para $55,0 \%$ de OTR, produzindo um concentrado com 15,3\% (e 5,6\% de Fe, correspondendo a $19,04 \%$ de recuperação), com descarte de massa de $73,54 \%$. 
Como conclusão final, Borges et al. (1995) verificam a impossibilidade de obter um concentrado apenas por métodos físicos de concentração, recomendando técnicas de metalurgia extrativa diretamente sobre o minério.

Os primeiros ensaios de extração de terras raras do minério silexítico de Catalão I foram conduzidos por Rocha \& Trindade (1993), visando abrir o minério e decompor a monazita em hidróxido de ETR insolúvel, e permitindo a separação do silicato de sódio solúvel, co-produto do processo com valor comercial. Alternativamente, a solubilização da sílica permitiria a exposição da monazita a um posterior ataque ácido.

Foi utilizada uma solução de $\mathrm{NaOH}$ com relação soda/minério variando de 1 a 2,2 e temperaturas variando entre 150 e $200^{\circ} \mathrm{C}$, por 1 ou $3 \mathrm{~h}$, em autoclave. A dissolução da sílica foi superior a $90 \%$ a partir de $170^{\circ} \mathrm{C}$, independente da concentração de $\mathrm{NaOH}$ e do tempo de reação, mas a decomposição da monazita depende fortemente de todas as variáveis, atingindo um máximo de $84 \%$ a $200^{\circ} \mathrm{C}, 2$ horas de reação e soda/minério $=2,2$.

A partir do resultado do trabalho de Rocha \& Trindade (1993), Barbosa et. al. (1995) optaram por otimizar a dissolução da sílica sem decompor as terras raras, decomposição essa controlada pelo teor de $\mathrm{P}_{2} \mathrm{O}_{5}$ (proveniente da reação da monazita) na solução. Os melhores resultados - extração de sílica superior a $96 \%$, extração de $\mathrm{P}_{2} \mathrm{O}_{5}$ inferior a $1 \%$ - foram obtidos a $200^{\circ} \mathrm{C}$, razão soda/sílica de $1: 1$ e uma hora de lixiviação. O silicato de sódio assim obtido foi considerado um co-produto com características compatíveis com as especificações do mercado. 


\section{Minério Laterítico}

Aquino \& Albuquerque (1996) desenvolveram extenso programa de desenvolvimento de rotas de beneficiamento por métodos físicos, visando concentrar as terras raras no minério laterítico do Córrego do Garimpo, Catalão I - GO.

As amostras foram sempre preparadas por um circuito contínuo de britagem, moagem, classificação e deslamagem, com corte $\left(d_{50}\right)$ em $3,7 \mu \mathrm{m}$, e por volta de $50 \%$ abaixo de $17 \mu \mathrm{m}$. Essa deslamagem promove uma perda de 12,7\% dos ETR nos finos.

Os resultados dos ensaios de flotação convencional, em célula mecânica, foram precários, apesar de serem testados diversos coletores (tall-oil, óleo de arroz, sulfosuccinamato de sódio, ácido graxo modificado, éster derivado de sulfosuccinamato, berol), e diversas concentrações de depressor (amido, collamil) e valores de $\mathrm{pH}$. Como exemplo, o maior teor obtido (12,88\% OTR) permitiu recuperação de apenas $15,2 \%$ das terras raras. Em função desses péssimos resultados, e considerando-se também as características da amostra, principalmente granulometria e alto teor de ETR nos finos, foram executados também testes de flotação em coluna. Os resultados, apesar de melhores do que os obtidos pela flotação convencional, também foram insuficientes, atingindo, no máximo, teor de OTR de $11,5 \%$, com recuperação de $74,5 \%$ (além das perdas da deslamagem, ou seja, recuperação global de $65 \%$ ).

Aquino \& Albuquerque (1996) também conduziram diversos testes de separação magnética, a seco e a úmido, para redução do teor de Fe nos concentrados, mas o máximo conseguido foi reduzir de $17,8 \%$ na alimentação para $11,3 \%$ no concentrado magnético (a úmido), com perda de OTR de $13,8 \%$. Os autores concluem não recomendando processos físicos de concentração (flotação e separação magnética) para esse minério. 
Uma amostra similar também foi testada pelo CETEM (Viera et al. 1998). Além de caracterização, foram executados ensaios de flotação (convencional) após atrição, concentração gravítica e magnética.

Para todos os ensaios executados por Viera et al. (1998) o minério foi deslamado (em $37 \mu \mathrm{m}$ ) e cominuído a $\mathrm{P}_{80}=147 \mu \mathrm{m}$. Nos testes de flotação, o material deslamado e cominuído foi pré-tratado em célula de atrição, a $150 \mathrm{rpm}$, por 10 minutos, com ácido sulfúrico de $\mathrm{pH} 1$. O teor da amostra deslamada alimentada, que era de $3,1 \%$ de OTR, passou, no melhor ensaio, a $3,7 \%$, confirmando a conclusão de outros autores que flotação não é processo indicado.

A amostra deslamada também foi submetida à separação gravítica em mesa Mozley. Determinou-se que a separação na mesa até 6 minutos permitia um descarte razoável da massa $(41 \%)$ com poucas perdas em termos de OTR, permitindo a recuperação de $59 \%$ da massa com $3,1 \%$ de OTR, teor idêntico ao alimentado. Os produtos foram analisados por MEV, e detectou-se predominância de vermiculita, flogopita e quartzo nos rejeitos, e de monazita, ilmenita e magnetita no concentrado. Como fases subordinadas, o rejeito apresentou muitas pequenas inclusões de monazita em quartzo, e o concentrado apatita e anatásio.

O concentrado da mesa Mozley foi submetido a separação magnética a úmido (HGMS Boxmag Rapid), em diversas intensidades de campo. Comprovou-se que em 0,1 T (1 kG) eliminou-se magnetita e ilmenita, em $0,3 \mathrm{~T}$ ilmenita, apatita e óxidos/hidróxidos de Fe. A monazita concentra-se bem a 1,0 T, acompanhada da gorceixita. A 1,85 T puderam ser retiradas apatita, gorceixita, monazita e quartzo.

Um eventual concentrado obtido a $1,0 \mathrm{~T}$ representaria $6,4 \%$ da massa original processada, e teria um teor de $18,1 \%$ de OTR. Dessa forma, Viera et al. (1998) sugerem um procedimento que incluiria uma britagem a $100 \%-3,3 \mathrm{~mm}$, deslamagem a 
$37 \mu \mathrm{m}$, moagem da fração mais grossa $\mathrm{P}_{80}=147 \mu \mathrm{m}$ com separação gravítica seguida de separações magnéticas a baixo e alto campos. O primeiro produto gerado seriam os finos, correspondentes a $70,2 \%$ dos OTR, com teor de $15 \%$ e perfazendo $35 \%$ da massa. Esse produto não é passivel de concentração, e teria que ser processado por meios hidrometalúrgicos. O segundo produto seria exatamente o concentrado das separações gravítica e magnética, que representaria $6,4 \%$ da massa alimentada, com $5,2 \%$ dos OTR e teor de $18,1 \%$. Os rejeitos dessas separações teriam um teor da ordem de $1,0 \%$ de OTR e $58,6 \%$ da massa, representando uma perda total de $24,6 \%$ das terras raras.

Baseando-se na elevada concentração da monazita nos finos naturais e na sua elevada friabilidade, Tassinari et. al. (1998) desenvolveram uma tecnologia alternativa para a sua concentração. Consiste em remover os finos naturais da amostra, e depois submetê-la a um ou dois ciclos de atrição a $2000 \mathrm{rpm}$ em pH regulado em 8,7 pela adição de $\mathrm{NaOH}$, sempre deslamando a amostra depois de cada ciclo. Dessa forma, foi possível obter um concentrado fino inicial com teor de 19,4\% de OTR, significando 45,65 de recuperação em $19,8 \%$ da massa total. O primeiro ciclo de atrição gera um concentrado com teor de $25,6 \%$ de OTR, $8,69 \%$ da massa e recuperação de mais $7,26 \%$ dos OTR. Um produto final de deslamagem dos finos naturais mais os gerados por um ciclo de atrição recuperaria $72,05 \%$ dos OTR, com teor de $21,3 \%$ em $28,5 \%$ da massa. Uma segunda atrição permitia recuperar mais $5,14 \%$ dos OTR, num produto com $17,2 \%$ do elemento e $2,51 \%$ da massa alimentada. Um eventual produto final de finos naturais mais os gerados em dois ciclos de atrição permitiria um concentrado com teor de $20,9 \%$ de OTR, $77,19 \%$ do inicial e com descarte de massa da ordem de $69 \%$. Ciclos adicionais de atrição não produziram resultados satisfatórios. 
O teor de $\mathrm{Fe}$, no entanto, é sempre alto: no produto gerado com um ciclo de atrição, é de $35,9 \%(36,23 \%$ do total $)$, e com dois ciclos de atrição $34,9 \%(38,22 \%$ do total). Tentativas de remoção de $\mathrm{Fe}$ por separações magnéticas de alto gradiente também não produziram bons resultados. 


\begin{abstract}
Amostras
A clássica ocorrência de ETR relacionada ao carbonatito de Catalão I eram os blocos de silexito mineralizado encontrados na localidade do Córrego do Garimpo, pertencente à Goiasfértil. Segundo informaçöes dos técnicos da empresa, os blocos teriam sido retirados de uma antiga galeria de prospecção, já fechada. As amostras do primeiro tipo de minério, denominado de minério silexítico ${ }^{1}$, vem de uma mistura de diversos desses blocos, detonados no pit da Goiasfértil (agora Ultrafértil) gerando uma amostra de aproximadamente $245 \mathrm{~kg}$. Essa amostra também serviu aos primeiros estudos tecnológicos efetuados pelo CETEM (Rocha \& Trindade 1993, Neumann et al. 1994, Borges et al. 1995), e os resultados obtidos foram fator determinante para a retomada dos trabalhos de pesquisa geológica e tecnológica pela empresa, iniciada concomitantemente pela execução de sondagens rotativas e estudos de viabilidade técnica.
\end{abstract}

Ainda durante a realização das sondagens, quando ficou caracterizado que um minério laterítico (ou saprolítico, segundo denominação do geólogo da empresa) era de fato o mais importante, as frentes de lavra de fosfato da Goiasfértil, próximas à area de ocorrência dos ETR, começaram a revelar um material esverdeado, que numa investigação preliminar mostrou ter teor considerável dos elementos e monazita

\footnotetext{
1 O termo silexito tem implicações genéticas para a escola francesa, onde significa chert, e é reconhecido por alguns autores como sinônimo também de quartzolito, rocha ignea com mais de $90 \%$ de quartzo (Jackson 1997). Não se pretende dar conotação genética ao termo, mas não foi encontrado um apenas descritivo melhor. A definição formal do termo silicito (como utilizado por Pereira 1995) também não foi encontrada, e silcrete (utilizado por Morteani \& Preinfalk 1996) tem implicações ainda mais comprometedoras. Dessa forma, o termo consagrado silexito foi mantido nesse trabalho, sem qualquer intenção de the atribuir conotaçäo genética.
} 
importante. Foi então realizada pela empresa uma amostragem nas frentes de lavra, e da homogeneização e quarteamento de aproximadamente $50.000 \mathrm{~kg}$ de minério obteve-se uma amostra do minério laterítico. Trata-se de um material castanho avermelhado e terroso, com algumas concreções mais claras, amareladas a esverdeadas, e fragmentos duros de silexito.

As primeiras sondagens na área de ocorrência das terras raras comprovaram a importância dos tipos citados acima, minérios laterítico e silexítico, estimando-se para este último $10 \%$ da jazida, mas distribuídos em corpos supostamente tabulares de dimensões centimétricas a alguns metros. A evolução das pesquisas atribuiu ao tipo silexítico uma importância crescente novamente, e hoje estima-se que os tipos silexítico e laterítico tenham igual representação. A partir de uma profundidade de 220 $\mathrm{m}$, e por aproximadamente $30 \mathrm{~m}$, foi encontrada uma rocha carbonática mineralizada e maciça, constituída por dolomita, magnesita e monazita, além de clinoenstatita, pirita e estroncianita, e da qual se obteve uma amostra do assim chamado minério carbonatítico. Como só pôde ser detectado em poucos testemunhos de sondagem, a amostragem decorrente absolutamente não garante representatividade. Os estudos desenvolvidos com essa amostra foram limitados a uma caracterização mineralógica e uma avaliação de espectro de liberação a partir da rocha não fragmentada. Nesse caso, pretendeu-se gerar dados preliminares, que poderão nortear decisões de ordem técnica e econômica para aumento das reservas, ou no momento da expansão da mina. A proveniência exata das amostras está registrada nos mapas das Figuras $3.1 \mathrm{e}$ 3.2 . 


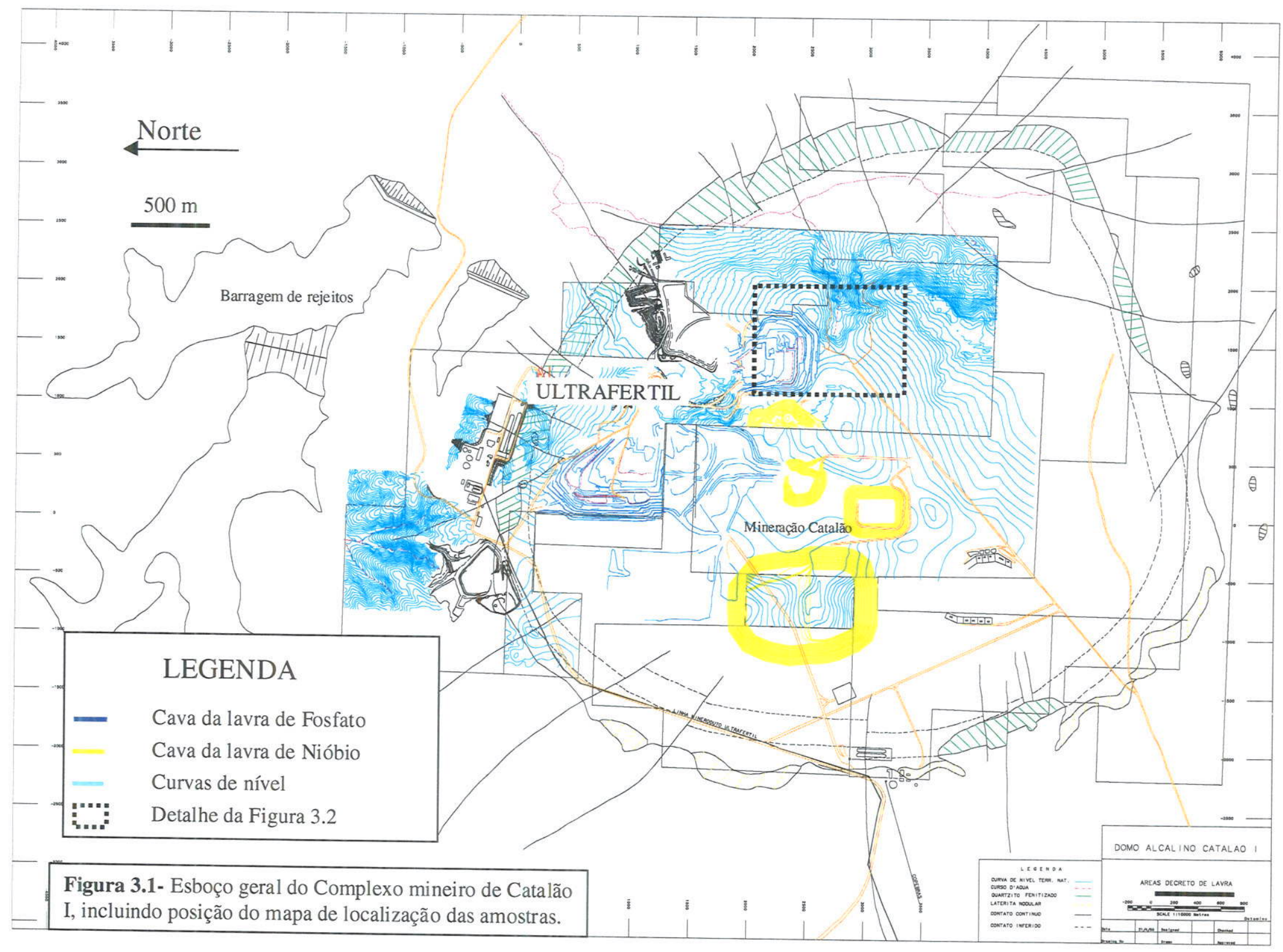




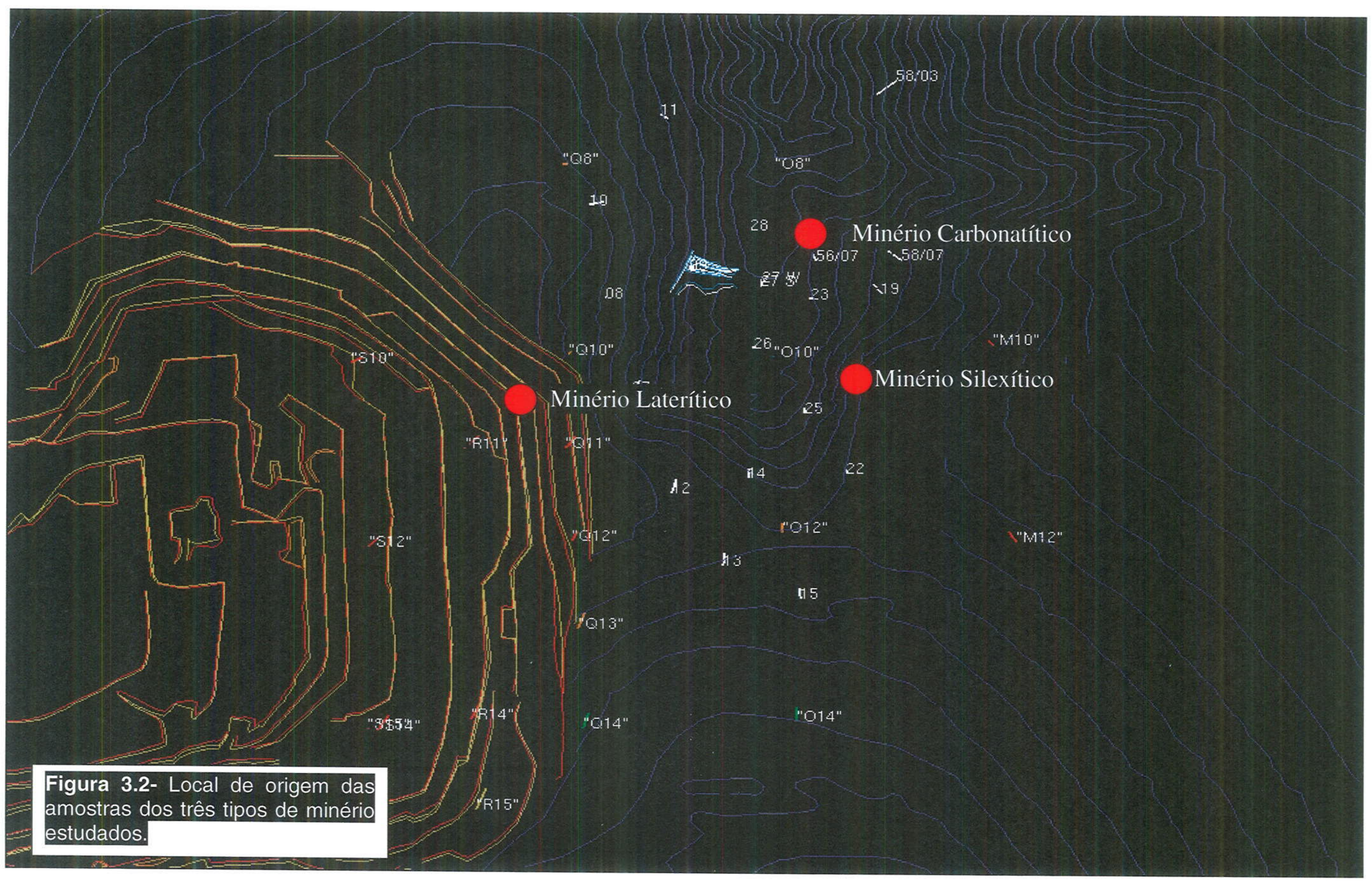




\section{Preparação das Amostras}

\section{Minérios sillexitico e laterítico}

A preparação das amostras de minério laterítico e silexítico foi idêntica. Todo o material recebido foi cominuído em britador de mandíbulas e moinho de rolos a $100 \%$ abaixo de 1,68 mm (10 malhas), com peneiramento intercalado para evitar formação de finos. O total da amostra foi homogeneizado em pilhas cônica e triangular alongada, e dessa última separaram-se aproximadamente $20 \mathrm{~kg}$ para todo o procedimento de caracterização (fluxograma de blocos da Figura 3.3), incluindo análise química da amostra de cabeça.

Por volta de $5 \mathrm{~kg}$ foram moídos (moinho de discos) abaixo de $105 \mu \mathrm{m}$, novamente intercalando peneiramento para evitar finos, e classificadas seguindo a série Tyler, até $20 \mu \mathrm{m}$ (635 malhas). A decisão de reduzir o top size e incluir a última peneira advém do conhecimento prévio da péssima liberação esperada para os minérios e do tamanho reduzido das partículas.

Uma alíquota representativa de cada fração granulométrica foi embutida e polida, para estudo de espectro de liberação do(s) carreador(es) de ETR em relação à sua ganga. Os procedimentos específicos estão descritos no respectivo tópico.

$O$ restante de todas as frações foi passado em meio denso (bromofórmio, $D=$ 2,90). Os afundados passaram pelo imã de mão (ferrite) e, em seguida, pelo separador magnético isodinâmico Frantz, a 0,1,0,3,0,5, 0,8, 1,0, 1,5 e 1,85 A, que gera campos magnético aproximados de, respectivamente, 1, 3, 5, 8, 10, 15 e 18,5 kG. As intensidades de corrente foram definidas em trabalhos anteriores por tentativa e erro, $\mathrm{e}$ geralmente promovem uma separação relativamente eficaz dos minerais presentes 
nesse tipo de minério. Todos os produtos assim gerados, inclusive os flutuados, foram preparados para difração de raios $X$ e análise química, além de embutimento $e$ polimento para análise ao MEV, à exceção dos produtos sem quantidade de material para tal.

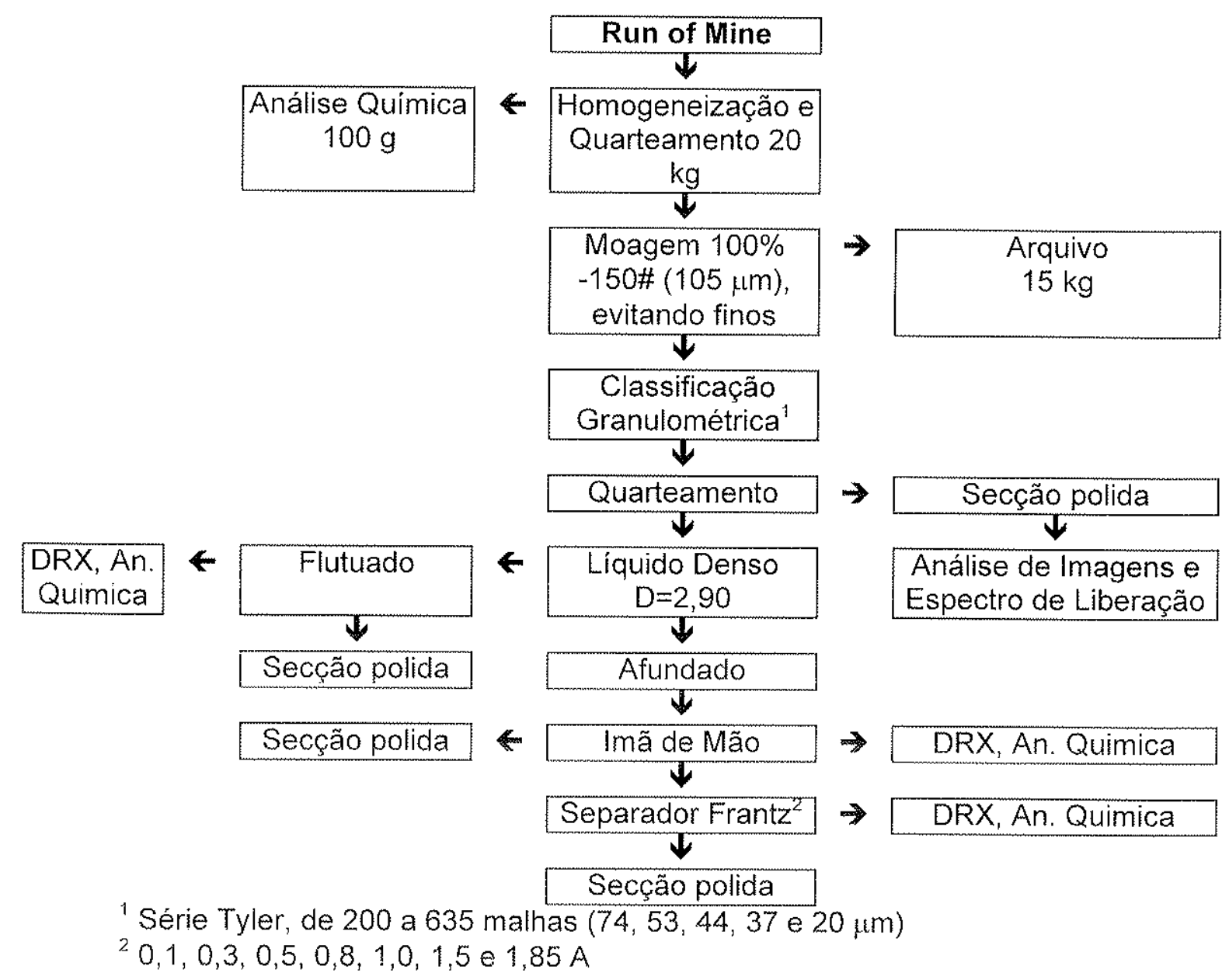

Figura 3.3 - Fluxograma do procedimento adotado para caracterização das amostras de minérios laterítico e silexítico do Córrego do Garimpo.

\section{Minério carbonatitico}

Da amostra de minério carbonatítico, representada apenas por um segmento de testemunho de aproximadamente $10 \mathrm{~cm}$ de comprimento por $4,8 \mathrm{~cm}$ de diâmetro, foi serrado um disco ortogonal à sua maior direção, que foi embutido em resina (em 
fôrmas de 2 polegadas), inclusive sob alto vácuo $\left(10^{-5}\right.$ bar) para preenchimento de poros e fraturas para melhorar a integridade da superficie durante o polimento, e polida para análise ao MEV e análise de imagens. O restante do segmento de testemunho foi cominuido a $100 \%$ abaixo de $105 \mu \mathrm{m}$ para análises por difração de raios $X$ e química.

\section{Análises Instrumentais}

\section{Difração de raios $X$}

Pequena quantidade de material, separada por quarteamento, foi intensamente moída em gral de ágata, até que não se percebessem mais os grãos no procedimento. O material foi então conformado nos porta-amostras de plástico com auxilio de uma lâmina de vidro. No caso de quantidade insuficiente, utiliza-se uma "palmilha" de PVC com uma pequena depressão no centro, onde o material é depositado e depois prensado. Análise da "palmilha" de PVC não acusou nenhum pico.

As análises foram executadas em difratômetro Siemens AXS D5005, equipado com espelho de Goebel, trocador automático de amostras de 40 posições e detector de estado sólido de $\mathrm{NaJ}$. As condições de análise foram sempre mantidas constantes: radiação de Cu $\mathrm{K} \alpha(\lambda=1.54184 \AA), 40 \mathrm{kV}, 40 \mathrm{~mA}$, geometria $\theta / 2 \theta$, range de análise 3 a $150^{\circ} 2 \theta$, passo de $0,02^{\circ} 2 \theta$, tempo de análise 2,0 s por passo, fendas fixas de entrada do espelho $1 \mathrm{~mm}$, saida do espelho $0,6 \mathrm{~mm}$, fendas divergente e do monocromador de $0,2 \mathrm{~mm}$, e amostra em rotação durante a análise a $60 \mathrm{rpm}$ (spinner). Como o espelho de Goebel altera a geometria de Bragg-Brentano para paralela, não houve preocupação de deslocamento dos picos causado pela altura da amostra, dentro dos limites da abrangência do feixe. Apesar de não ser sempre necessário, utilizou-se 
monocromador secundário curvo de grafite perolizado em todas as análises, uma vez que boa parte das amostras tem teores mais elevados de $\mathrm{Fe}$, gerando fluorescência, e o objetivo era manter as condições de análise constantes para permitir comparação de resultados.

Os espectros obtidos foram interpretados digitalmente por comparação com banco de padrões (ICDD 1996).

\section{Confecção de Seç̧ões Polidas}

Para o embutimento a frio das amostras utilizou-se resina Araldite LMB 279 e endurecedor XR-1951. Essa resina tem uma viscosidade de aproximadamente metade dos Araldites convencionais, permitindo uma melhor eliminação das bothas. Como existe a possibilidade de segregação por diferença de densidade nas amostras em grão embutidas, é importante que se tenha uma camada de pelo menos $3 \mathrm{~mm}$ de altura de amostra dentro da fôrma, uma vez que testes empíricos demostraram que o imbricamento dos grãos permite segregação apenas no milímetro superior.

Após esta etapa, cada amostra foi desbastada e polida. O processamento foi feito com discos diamantados de $125,40,15,9,6$ e $3 \mu \mathrm{m}$, e suspensão de diamante de $1 \mu \mathrm{m}$. Foi utilizado exclusivamente diamante para desbaste/polimento, para evitar eventual contaminação, que havia sido detectada com freqüência quando utilizada a alumina. Os discos de diamantes fixos em matriz metálica (metal bond) permitem um desbaste mais rápido e com menor tempo dispendido na troca do meio, e ultrassom é necessário apenas ao final do polimento, uma vez que as únicas partículas soltas advem do próprio desbaste da amostra, facilmente elimináveis com lavagem com água. Optou-se por limpeza ultrassônica por 15 minutos em água desmineralizada. O fato, 
aliás, de se usar os discos diamantados magnéticos permite uma flexibilidade muito maior justamente pela troca da grana do diamante ser apenas a troca do disco autoaderente magneticamente.

\section{Coating condutor}

As seções polidas foram recobertas com carbono em evaporador Baltech SCD005/CEA-035, utilizando fio de carbono espectrograficamente puro, com aplicação em duas camadas e rotação da amostra em $90^{\circ}$ entre as aplicações.

\section{Microscopia Eletrônica de Varredura com Microanálise por Dispersão de Energia (MEV/EDS)}

As seções polidas devidamente recobertas com carbono foram analisadas em MEV Leica S440. As imagens geralmente foram geradas por detector de elétrons retroespalhados, que gera os níveis de cinza proporcionais ao peso atômico médio do material analisado; assim, quanto maior o seu peso atômico, mais claras as fases aparecem na imagem.

Além disso, foram obtidos espectros de composiçäo química qualitativa por dispersão de energia (EDS) em pontos de área de aproximadamente $2 \mu \mathrm{m}$, selecionados nas imagens, O EDS é um Link ISIS L300 com detetor de SiLi Pentafet, janela ultrafina ATW II, de resolução de $133 \mathrm{eV}$ para $5,9 \mathrm{keV}$. Foram também executadas análises semi-quantitativas por EDS, utilizando perfis dos elementos obtidos no mesmo equipamento em que foram executadas as análises, a partir de padrões certificados, especiais para esse fim, fornecidos pela empresa inglesa Micro- 
Analysis Consultants Limited (padrão registrado $n^{\circ} 3890$ ), e o equipamento foi calibrado com padrão certificado de cobalto de pureza $99,995 \%$ a cada 30 minutos, praticamente eliminando efeitos de flutuação na intensidade do feixe. O tempo de aquisição de espectro para o padrão e para cada análise foi o mesmo, equivalendo a 100 segundos mais a correção de dead time, e o process time de 4. A quantificação dos elementos a partir dos espectros considerou correções de ZAF (números atômico e de massa, fluorescência), e foi realizada pelo programa SEMQUANT, da suite Oxford ISIS L300. A maior dificuldade em conseguir resultados coerentes das análises semi-quantitativas advém da superfície irregular da amostra, apesar do excelente polimento. Dessa forma, foram utilizadas imagens de elétrons secundários (mais apropriadas para visualização de morfologia da superfície), além das de elétrons retro-espalhados, para direcionar o feixe para locais mais planos. Os dados foram sempre obtidos completos, sem normalização, recálculo para 100\% ou para óxido (o oxigênio foi sempre medido), de maneira que a qualidade da análise foi também avaliada pela sua totalização.

Por ocasião do tratamento dos dados de microanálise, no entanto, foi necessário recalcular, por exemplo, as análises de monazita, uma vez que a totalização sempre ficou entre 86 e $98 \%$ (totais inferiores provocaram a eliminação do dado); segundo dados diversos da bibliografia (por exemplo, Pereira 1995), e discussão com especialista que executou análises por microssonda eletrônica em amostras de Catalăo, Dra. Maria Cristina Motta de Toledo, esse fenômeno é derivado da própria amostra, possivelmente por efeito de vazios (microporosidade), de maneira que o recálculo para $100 \%$ simplesmente corrige uma situação incontornável e permite a comparação direta dos resultados. No caso de análises de óxidos, como pirocloro, anatásio, priderita, etc, os dados foram recalculados de elementos para óxidos para facilitar a comparação com análises já publicadas. O mesmo teria sido feito para 
apatita, mas como as análises de flúor por dispersão de energia sempre superestimam o elemento, optou-se por deixar as análises na forma original, de maneira que possam ser avaliadas por quem as usa.

\section{Análise Química}

As amostras foram previamente moídas até granulometria inferior a $105 \mu \mathrm{m}$ em gral de ágata, quando necessário. A grande disparidade nos resultados de análise por métodos instrumentais, principalmente as de ETR, gerou uma grande discussão com técnicos do Departamento de Análises Químicas e Ambientais do CETEM. Decidiu-se então adotar análises clássicas, por gravimetria, que permitiram acompanhamento de todos os sólidos (resíduos e precipitados) gerados nas etapas da análise por MEV/EDS, para verificar a sua eficiência. O fluxograma da Figura 3.4 ilustra o procedimento de análise finalmente adotado, que corrige grandes falhas na metodologia clássica que puderam ser identificadas, e que será publicado oportunamente. 


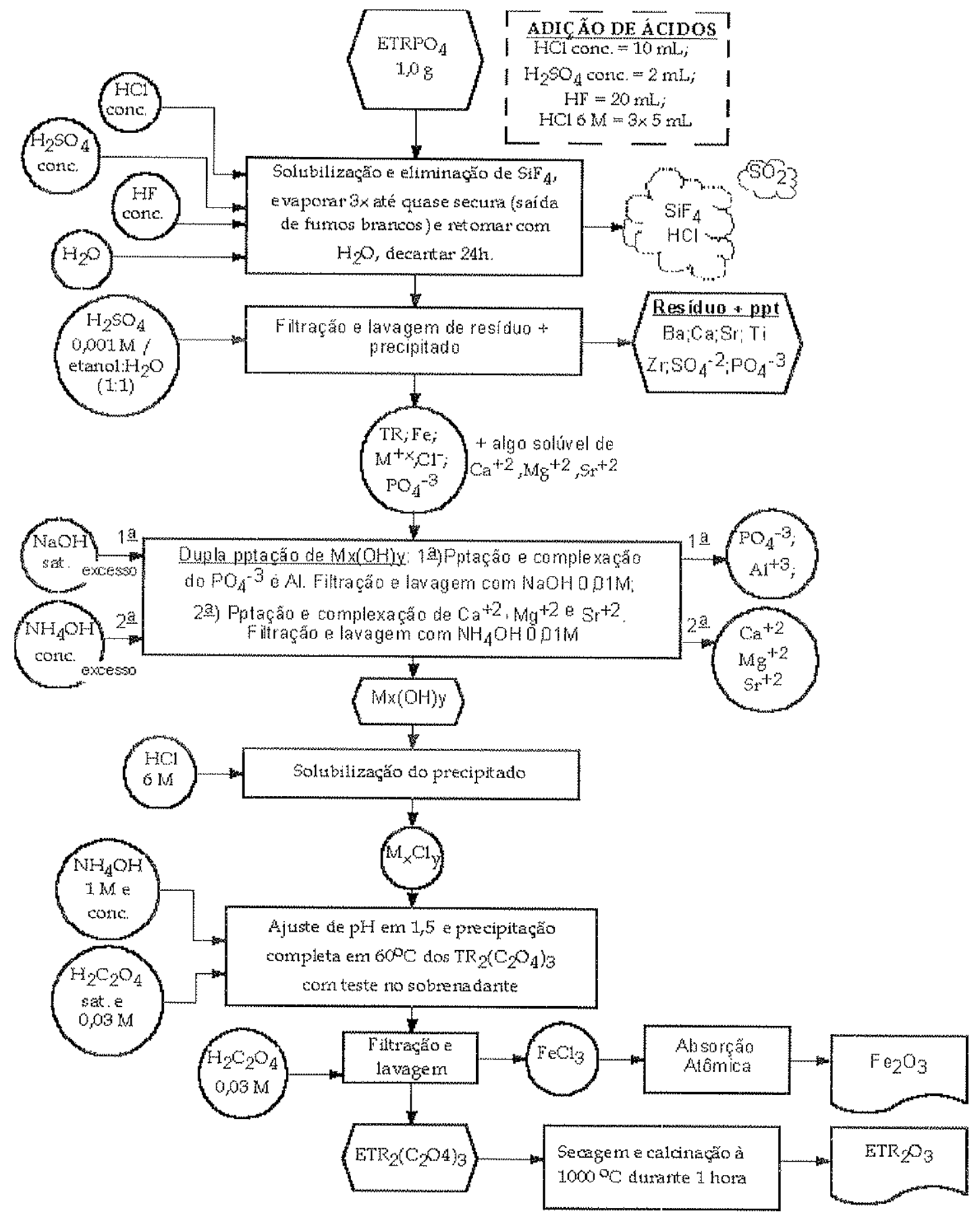

Figura 3.4- Fluxograma do procedimento adotado para análises químicas de $T_{2} \mathrm{O}_{3} \Theta$ $\mathrm{Fe}_{2} \mathrm{O}_{3}$ (total) de todas as amostras nesse trabalho. 


\section{Análise de lmagens}

\section{Aquísição das Imagens}

O primeiro passo para análise de imagens é a sua aquisição. Considerando-se que a imagem é a matéria-prima de toda a análise, vai sofrer uma série de modificações e correções, e que pequenas modificações mal feitas nas imagens podem provocar grandes erros ao final, a aquisição foi feita da maneira mais precisa possível. Em primeiro lugar, todo o MEV foi configurado para máxima emissão no segundo pico de saturação do filamento, em distância de trabalho ótima $(25 \mathrm{~mm})$ para sua geometria, e brilho e contraste regulado com auxilio do seu histograma para aproveitamento de praticamente todo o espectro de 256 niveis de cinza. As imagens foram adquiridas automaticamente pelo pacote de softwares OXFORD ISIS L300, que escraviza completamente o MEV. Depois de acertado o conjunto, foram definidas as coordenadas inicial e final da área da amostra a ser analisada, interativamente, e as imagens adquiridas e armazenadas pelo módulo AUTOBEAM da suite ISIS L300. O módulo AUTOSTAGE automaticamente moveu a platina para as posições da próxima imagem. O tempo de aquisição de cada imagem é de aproximadamente 1 min e $40 \mathrm{~s}$, e nenhuma adequação da distribuição dos niveis de cinza (muito comum para otimizar visualização da imagem) foi introduzida pelo software de aquisição.

Idealmente, a análise de imagem deveria ser efetuada com todas as partículas de um mesmo tamanho, o que é absolutamente inviável em mineralogia de processo e em grande parte das outras aplicações. A classificação utilizando todas as peneiras da série Tyler entre 150 e 635 malhas (105 e $20 \mu \mathrm{m}$, respectivamente), no entanto, gera produtos com variação no tamanho das partículas compativel com as análises 
efetuadas. A magnificação foi selecionada de maneira empírica, de acordo com o tamanho das partículas, permitindo aproximadamente 50 por imagem. Como foram utilizadas 99 imagens de cada fração, a análise de imagens considerou quase 5.000 partículas por fração. Usualmente, 2.000 são consideradas suficientes para ter representatividade estatística, mas decidiu-se por um número bem maior considerandose a complexidade dos minérios. A Tabela 3.1 apresenta a magnificação (em relação ao monitor de 17 polegadas que equipa o MEV) e a resolução (ou seja, tamanho do pixel) utilizado para cada tamanho de partícula. O tamanho de todas as imagens utilizadas é o máximo admitido pelo MEV, 1024 por 768 pixels.

Tabela 3.1 - Magnificação e resolução das imagens adquiridas, por tamanho de partícula.

\begin{tabular}{ccc}
\hline $\begin{array}{c}\text { Tamanho das partículas } \\
(\mu \mathrm{m})\end{array}$ & Magnificação $(\mathrm{X})$ & Resolução $(\mathrm{nm} /$ pixel) \\
\hline 105 a 74 & 400 & 759,54 \\
74 a 53 & 560 & 542,53 \\
53 a 44 & 720 & 421,96 \\
44 a 37 & 870 & 349,21 \\
37 a 20 & 1300 & 233,70 \\
\hline
\end{tabular}

Para previsão de liberação do minério carbonatítico, foi necessário gerar imagens adjacentes, com overlap, para permitir posterior emenda lateral das imagens e criação de mega-imagens recortadas em 9999 por 730 pixels. Para a sua aquisição, foi acionada a correção de folga de engrenagens (backslash correction) e o posicionamento final da amostra sempre se fez em baixa velocidade dos motores de passo, e sempre no mesmo sentido, de maneira que qualquer folga de engrenagens ou imprecisão de posicionamento pôde ser corrigida. Na prática, observou-se uma superposição média das imagens de 10 pixels.

As imagens geradas foram transferidas por FTP para o computador onde se procede à análise de imagens propriamente dita, em ambiente UNIX (ou LINUX, no 
CETEM), e renomeadas por software especifico para adquirirem terminação em numeração seqüenciada, pré-requisito para análise automatizada.

\section{Processamento das imagens}

O software utilizado para análise das imagens sempre foi o MMIA (Mineral and Metallurgical Image Analysis), desenvolvido e continuamente aperfeiçoado pelo Prof. Peter King e pelo Dr. Claudio Schneider, do Utah Comminution Center, University of Utah. Referências sobre esse programa, em suas versões iniciais, podem ser encontradas em King \& Schneider (1993), mas muitas modificações foram introduzidas desde então, e não estão documentadas, pois não existe manual de operação.

As rotinas de análise de imagem, basicamente, seguiram o seguinte padrão:

1- Aplicação de um filtro de delineação e deteç̧ão de borda de partículas. Para eliminação da gradação de borda de partículas - o limite entre um grão de monazita com nivel de cinza 200 com a resina de nivel 40 , por exemplo, gera um contorno em niveis de cinza intermediários, inclusive os correspondentes a quartzo, apatita, gorceixita e minerais de Fe. Na simples segmentação da imagem, portanto, poderiam ser criadas particulas de ganga que não existem, ou o processamento para eliminação desses halos de niveis de cinza poderia comprometer a integridade de bordas das particulas ou limites entre as fases, alterando sua textura e portanto inserindo um erro desnecessário na análise de imagens. Sempre foi utilizado filtro Sobel de matriz $5 \times 5$ (apesar de outras opções de filtros ou matrizes), cujo algoritmo é definido como (King \& Schneider 1993): 
Se $\left(g_{\max }-g_{i} \leq g_{i}-g_{\min }\right)$, então $g_{i}=g_{\max } \quad$ Equação 3.1

Senão $g_{i}=g_{\min }$

onde $g_{\min }$ e $g_{\max }$ são, respectivamente, o menor e o maior valor de nivel de cinza encontrado nos 24 pixels que rodeiam o pixel i. A rotina é executada duas vezes, do canto superior esquerdo para o inferior direito, e voltando. A imagem da Figura 3.6 equivale à da 3.5 após aplicação de filtro de delineação conforme descrito. Deve-se esclarecer que não foi necessária nenhuma correção prévia de ruído (background), uma vez que o detector de elétrons retro-espalhados utilizado tem sensibilidade totalmente homogênea em toda a área da imagem, o que foi medido e confirmado em superfícies lisas.

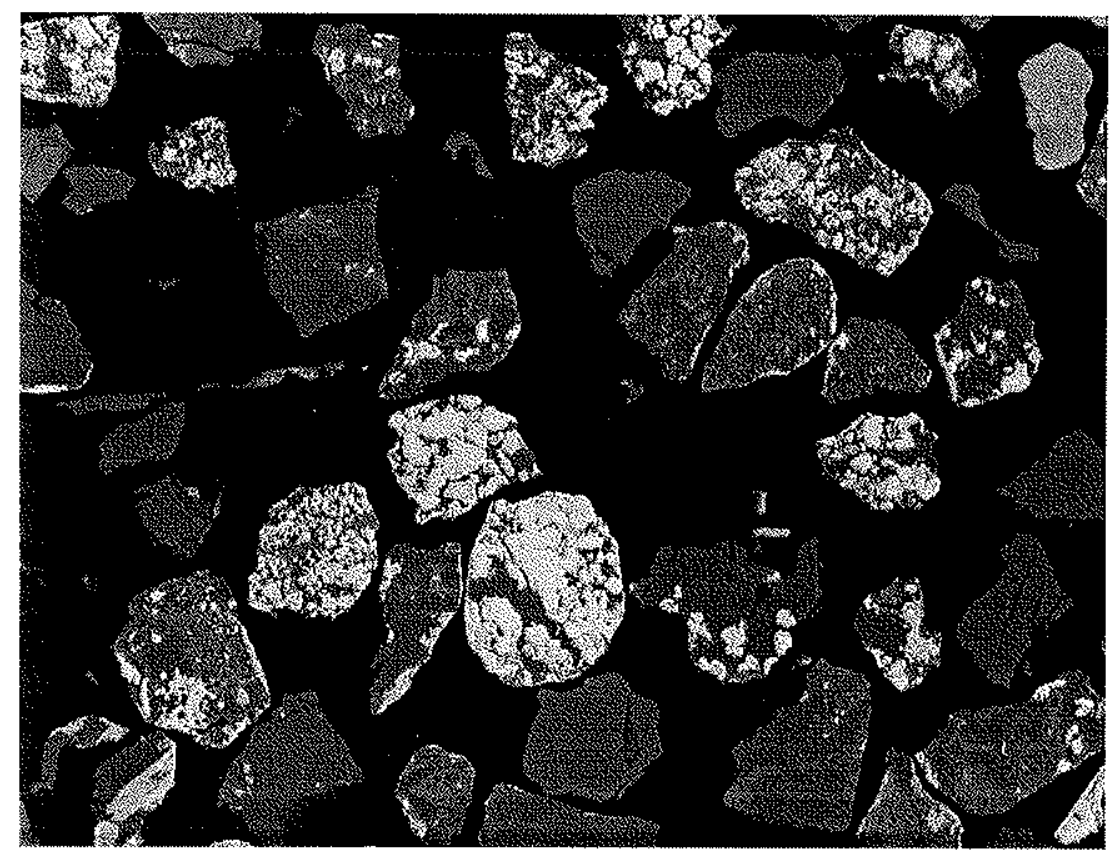

Figura 3.5 - Imagem do minério silexítico como adquirida pelo MEV, automaticamente, para análise de imagem. Cinza mais claro equivale à monazita, mais escuro (praticamente preto) à resina, cinza médio escuro ao quartzo e cinza médio mais claro a minerais de ganga (óxidos/hidróxidos de Fe). 


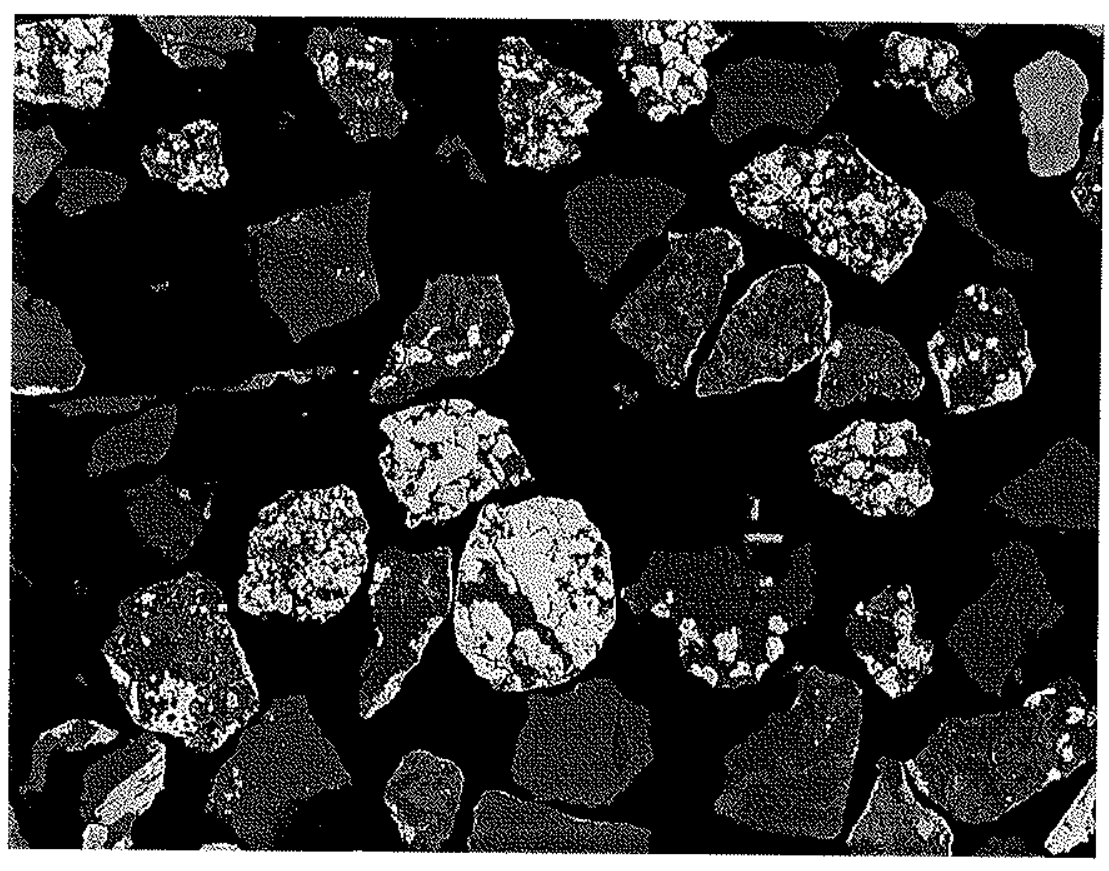

Figura 3.6 - Mesma imagem da figura anterior, após aplicação do filtro de delineação.

2- Segmentação da imagem. Geração de duas imagens binárias, uma de monazita e outra da ganga a partir de histogramas de números de pixels versus os 256 níveis de cinza. Como existe uma variação grande dos níveis de cinza, tanto da monazita como de alguns dos minerais de ganga (apatita, minerais de $\mathrm{Fe}$ ), a segmentação foi executada com valores definidos por processamento manual de boa parte das imagens. A variação nos niveis de cinza decorrentes de instabilidades do feixe de elétrons do MEV ou outras flutuações das condições instrumentais foi monitorada pela posição dos picos de resina e quartzo, e mostrou-se mínima, da ordem de 1 ou 2 niveis de cinza. As imagens das Figura 3.7 e 3.8 mostram, respectivamente monazita e ganga em imagens binárias derivadas da segmentação da imagem da Figura 3.6. 


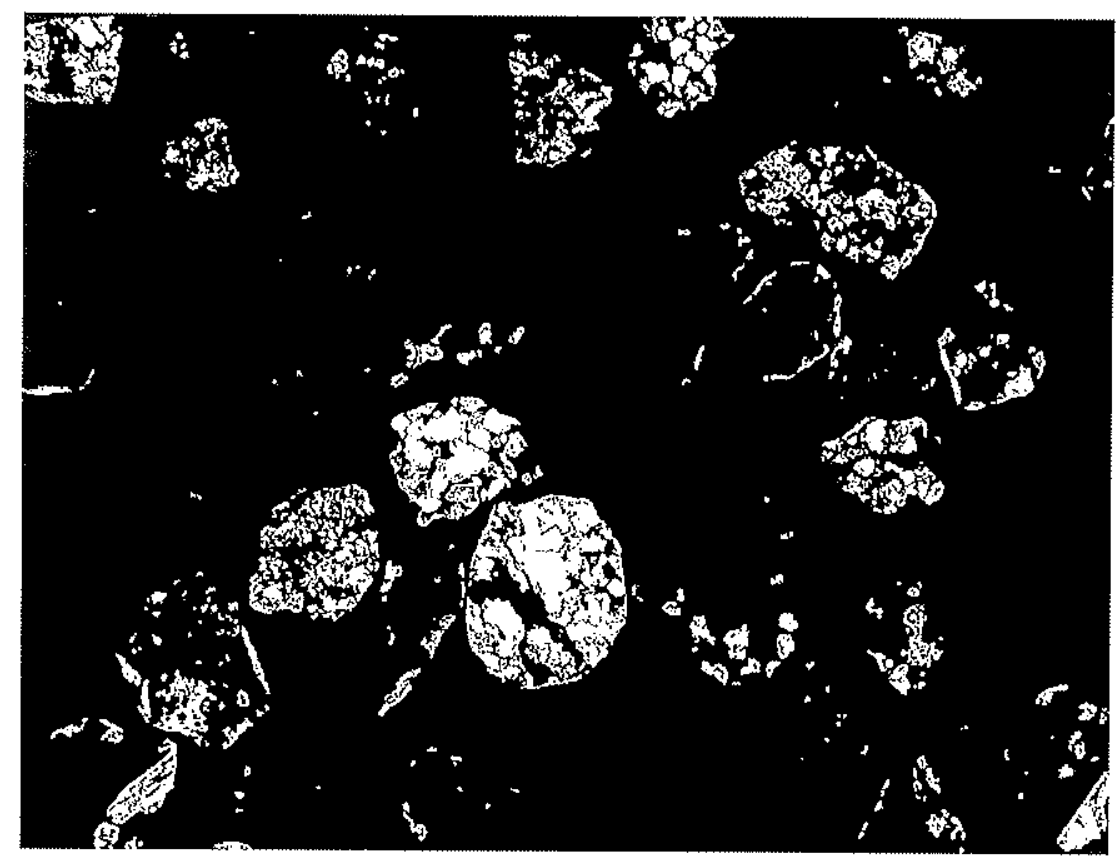

Figura 3.7- Imagem binária de monazita, segmentada a partir da imagem 3.6 (invertida para melhor visualização).

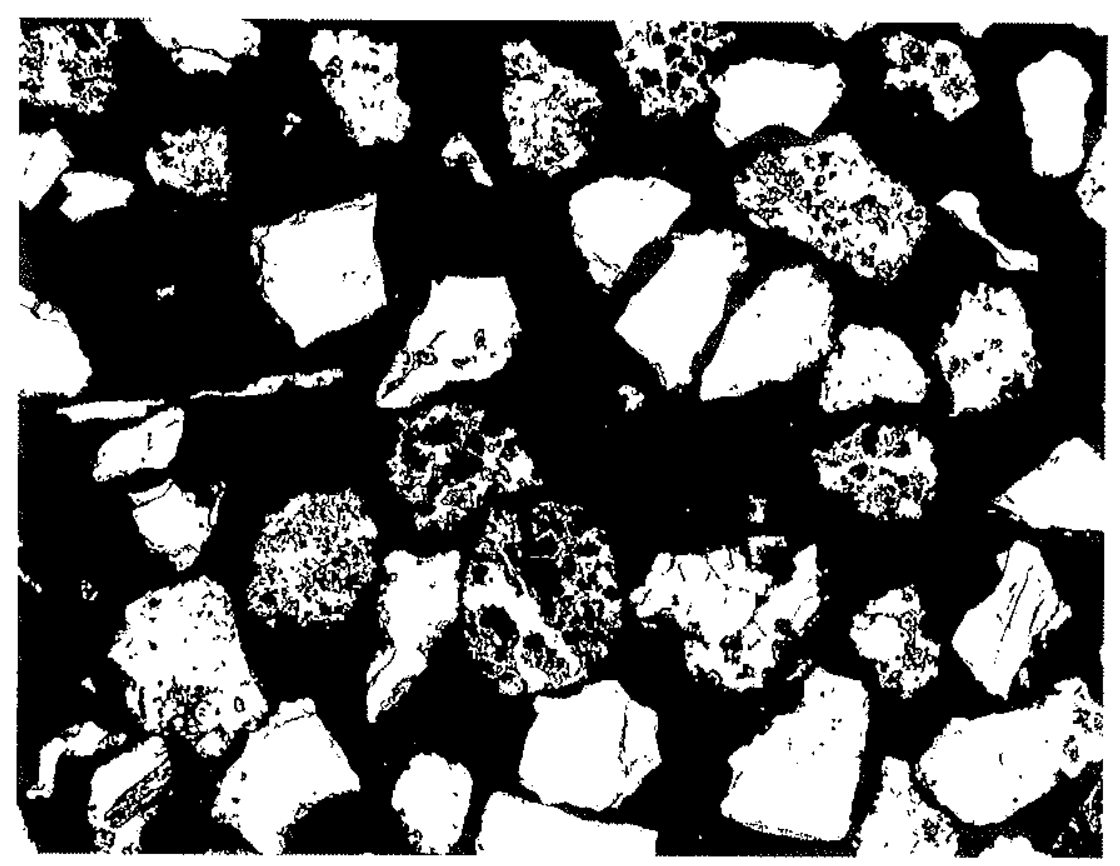

Figura 3.8 - Imagem binária da ganga, segmentada a partir da imagem 3.6 (invertida para melhor visualização).

3- Preenchimento das cavidades, da monazita e da ganga. O polimento de material friável pode gerar pequenas descontinuidades na superfície de partículas maciças. Como a monazita é sempre extremamente friável, as 
cavidades têm que ser preenchidas para não serem interpretadas como ganga. As cavidades, fraturas e outras imperfeições das partículas em geral têm que ser preenchidas, uma vez que a estereologia não admite partículas côncavas. A Figura 3.9 mostra a imagem binária de monazita após preenchimento.

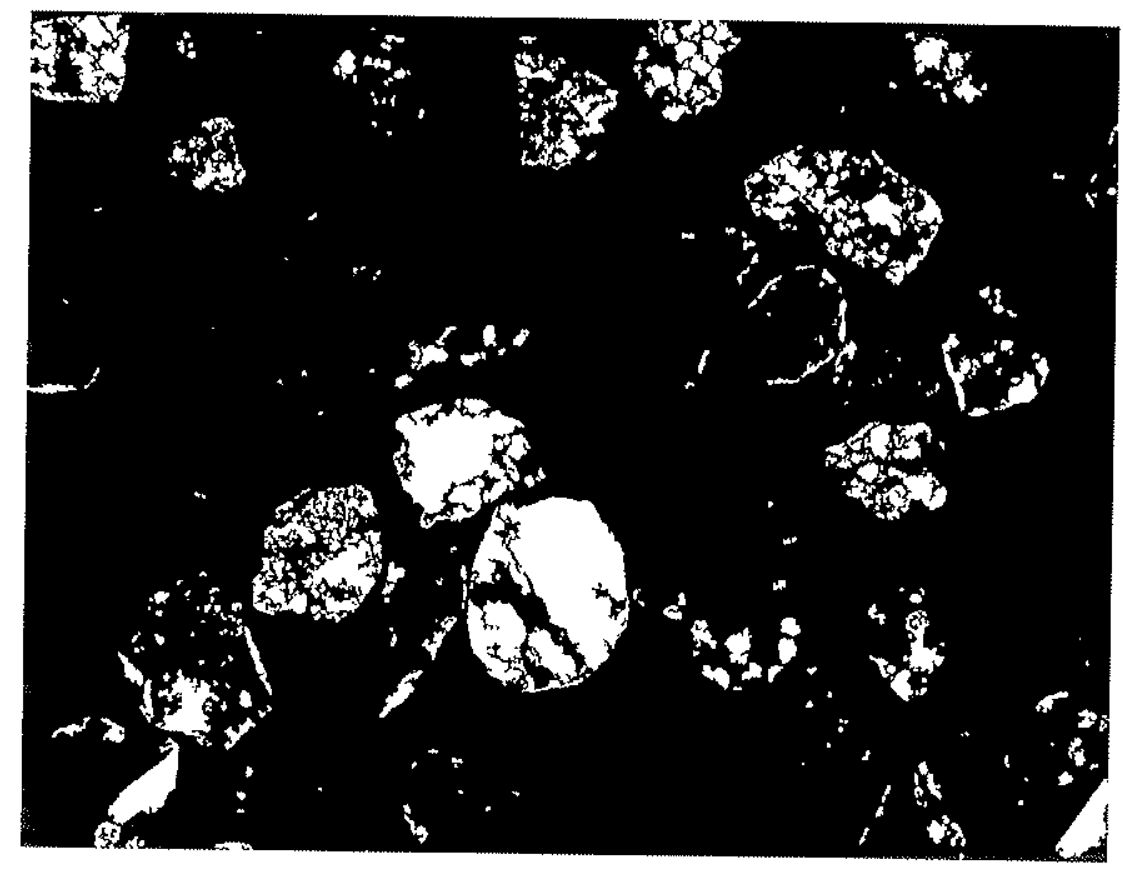

Figura 3.9 - Imagem binária de monazita após preenchimento de cavidades, fraturas e outras imperfeições (invertida para melhor visualização).

4- Eliminação de artifactos, apenas da ganga. Partículas muito pequenas, de poucos pixels, não afetam substancialmente o resultado da análise de imagem, e com razoável probabilidade são artifactos gerados pela própria análise da imagem (bordas de grão, porosidade, bolhas na resina, contato entre fases, ruido eletrônico), mas complicam muito o processo de análise de imagem. Assim, é preferivel eliminá-las. Como a monazita, por outro lado, é sempre muito fina, optou-se por manter todos os pixels segmentados como tal, uma vez que o erro por eliminá-los poderia ser muito grande. Ao invés da 
clássica rotina de erosão e dilatação das partículas, que modifica o contorno dos grãos, os artifactos foram eliminados a partir de um mapa de distâncias euclidianas (EDM). No mapa de distâncias euclidianas, gera-se uma matriz do tamanho da imagem (1024 colunas por 768 linhas), e atribui-se a cada pixel da imagem um indice resultante da soma de valores dos oito pixels vizinhos, com valores diferenciados: 0 para pixels adjacentes que não correspondem à fase em questão, 2 para cada pixel imediatamente adjacente acima, abaixo ou aos lados, e 1 para cada pixel adjacente diagonalmente. São eliminados da imagem binária os pixels com valor inferior ao previamente estipulado, usualmente 5. Como a imagem como um todo não é alterada, apenas são eliminados os pixels que não atendem ao especificado, forma, tamanho e morfologia de partículas não sofrem modificações. A Figura 3.10 apresenta a imagem da ganga, após preenchimento de cavidades e eliminação de artifactos por EDM. 


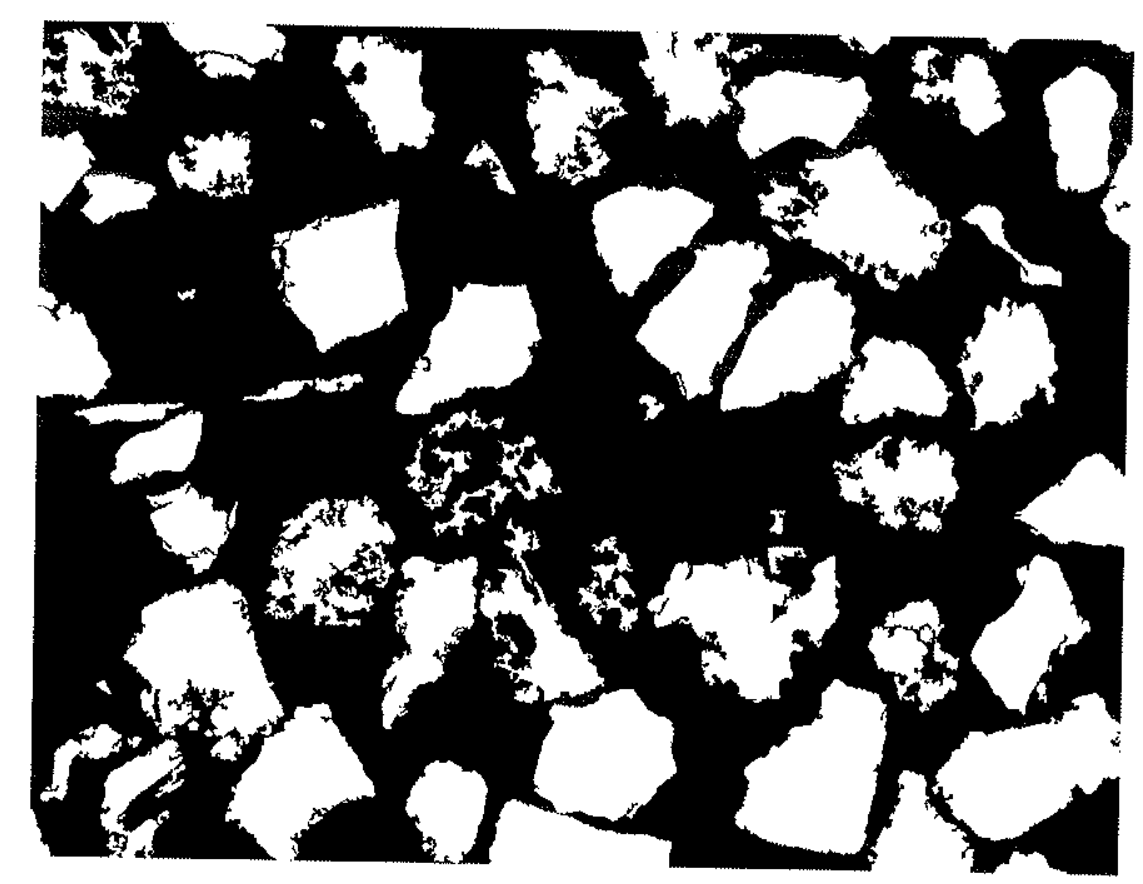

Figura 3.10- Imagem binária da ganga após preenchimento de cavidades e eliminação de artifactos por mapa de distâncias euclidianas (EDM) (invertida para melhor visualizaçäo).

5- Geração de imagem ternária. As imagens são recombinadas, gerando uma imagem ternária (resina, monazita e ganga). A monazita é superposta à ganga, remontando a imagem original, mas identificando monazita e ganga. A imagem ternária da Figura 3.11 apresenta o resultado dos procedimentos descritos até então. 


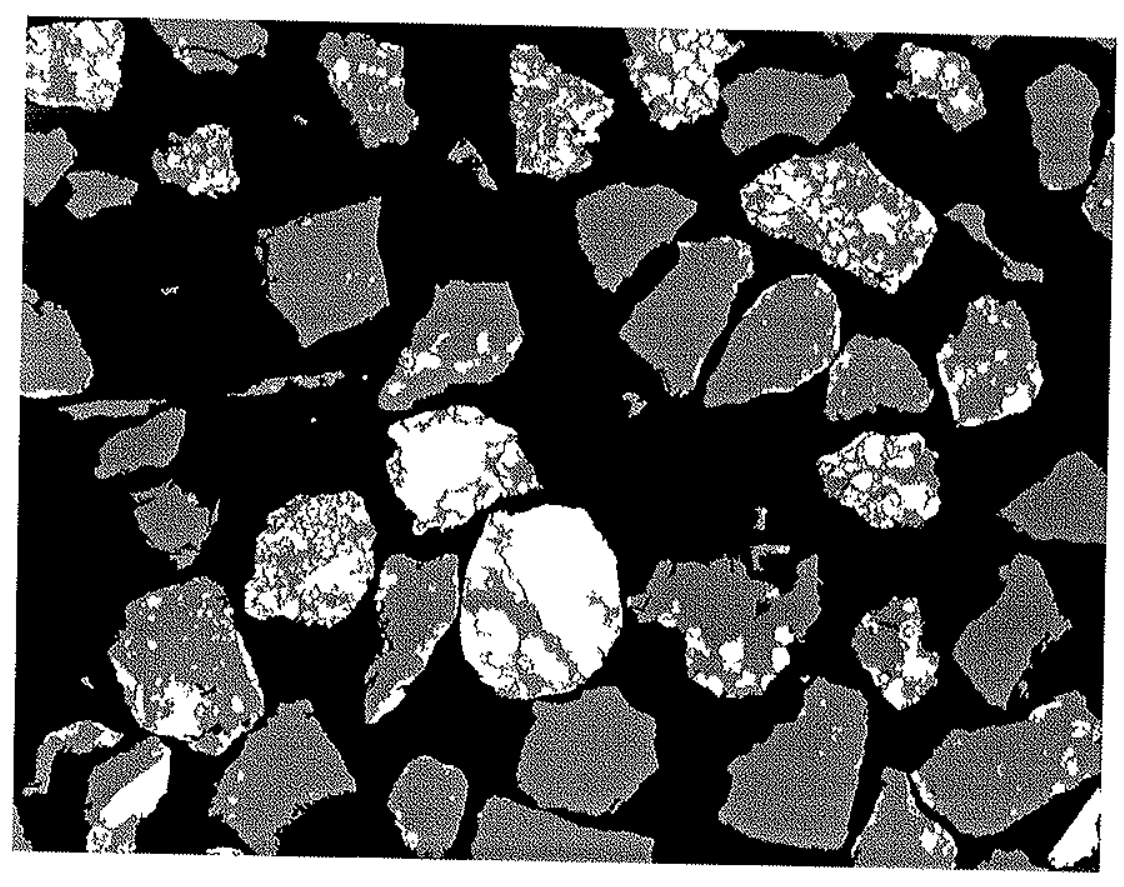
Figura 3.11 - Imagem ternária das partículas de monazita (branca), ganga (cinza) e
resina (preto).

6- Separação de partículas que se tocam. Teoricamente as partículas não deveriam se tocar, se a resina molhou perfeitamente todas elas. Para separar particulas adjacentes que se tocam, e que poderiam ser analisadas como uma única, de dimensões maiores, utiliza-se uma rotina de erosão por mapas de distâncias euclidianas e remontagem das particulas com erosão de pixels que conectam duas partículas que foram separadas no procedimento de erosão (convex watershed utilizando EDM).

7- Medidas finais. São as medidas que serão utilizadas como produto da análise de imagens. Geralmente são quantificados os pixels correspondentes a resina, ganga e monazita (permitindo o cálculo do teor, chamado de teor de ponto), o tamanho médio do contato entre resina, ganga e monazita, do qual se pode calcular o perímetro médio $\left(B_{A}\right)$ e a área superficial por volume dos grãos $\left(S_{V}=4 B_{A} / \pi\right)$. Perímetro médio e área superficial não foram utilizados 
nesse estudo. Além disso, são medidos os interceptos lineares, espaçados a cada 10 linhas nas imagens, resultando na distribuição de tamanho de interceptos totais, de ganga e de monazita que os compõem. A partir dessas medidas, podem ser calculados o teor de linha do minério e o espectro de liberação linear, por classes de teor de linha. Utilizaram-se 12 classes de teor: 0,0 a 10,10 a 20,20 a 30,30 a 40,40 a 50,50 a 60,60 a 70,70 a 80 , 80 a 90,90 a 100 e 100\% de monazita, e o espectro de liberação linear aparente é a normalização da distribuição linear acumulada para cada proporção de segmentos de monazita/ganga em cada intercepto. Além disso, mede-se também o espectro de liberação em área, a partir da área das partículas, mistas ou não, seguindo as mesmas 12 classes de teores.

Os teores de ponto, linha e área devem ser iguais, e em geral são muito próximos nas medidas efetuadas. A área da imagem utilizada para as medidas é inferior à área total da imagem, excluindo-se uma moldura de 10 pixels de cada lado da imagem, evitando-se assim o uso de eventual pixel não processado corretamente quando de sua delineação e procedimentos envolvendo EDM. Para as medídas de linha, são aceitas as medidas que terminam dentro dos 10 pixels finais (lado direito da imagem), mas não se elas começam dentro dos últimos 20. Para as medidas de área, não são considerados os grãos que tocam nas bordas. As medidas de espectro de liberação em linha e em área são corrigidas por causa dessas restrições nas medidas (correção de moldura), proporcionalmente à probabilidade que um intercepto ou uma partícula de determinado tamanho intercepte a moldura. 


\section{Correção estereológica}

O objetivo desse trabalho não é o desenvolvimento ou melhorias nos métodos existentes de correção estereológica, e sim a sua aplicação prática. Diversos pesquisadores ainda questionam a eficiência da correção estereológica para conversão de dados em uma ou duas dimensões para dados tridimensionais, particularmente para aplicações em tecnologia mineral (p.e., Dr. William Petruk, comunicação pessoal). Mas o fato é que os resultados de análises de imagens em dimensão 0 (contagem de pontos), uma dimensão (interceptos lineares) ou duas dimensões, enquanto muito úteis como dados qualitativos, estão errados se considerados como "espectro de liberação" (ou "grau de liberação") sem as necessárias conversões estereológicas. De forma intuitiva, basta um rápido raciocínio, imaginando-se uma população de esferas todas com metade branca e metade preta, seccionadas aleatoriamente, e onde o resultado nunca seriam os reais $50 \%$ de cada cor em todas as seç̧ões (Claudio L. Schneider, comunicação pessoal).

Na prática, a estereologia proporciona um conjunto de métodos que podem ser utilizados para calcular algumas propriedades de estruturas geométricas tridimensionais a partir de secções bidimensionais dessas estruturas (King \& Schneider 1993). A possibilidade de se utilizar dados de secções bidimensionais tem grande importância em mineralogia aplicada pela facilidade de observação em secções polidas ou delgadas, e os métodos estereológicos assumem uma importância ímpar pela possibilidade de fornecer os dados quantitativos, absolutamente necessários em tecnologia mineral.

Uma vez que em mineralogia aplicada é necessário trabalhar sempre com amostras (supostamente representativas), e que o material sempre tem textura e estrutura não-uniformes e não-determinados, somente é possivel executar medições 
de maneira estatística, e a estereologia é estatística por natureza; os métodos fornecem informaçöes das propriedades geométricas médias da estrutura, mas nenhuma informação de propriedades geométricas de determinado elemento na estrutura.

A transformação mais importante em mineralogia aplicada é a conversão de liberação linear aparente, em amostras particuladas, para o espectro de liberação tridimensional. A Equação 3.2 representa a transformação estereológica de liberação linear aparente para liberação tridimensional de partículas de tamanho D

$$
P\left(g_{L} \mid D\right)=\int_{0}^{1} P\left(g_{L} \mid g\right) p(g \mid D) d g
$$

onde gt representa o teor linear medido num intersecto da partícula e g é o teor em volume da partícula. A solução numérica da Equação 3.2 pode ser encontrada em Schneider et al. (1991). A função $P\left(g_{L} \mid g\right)$, particularmente, é dependente da textura mineralógica do minério, e pode ser calculada usando minérios perfeitamente fracionados, onde a composição de cada partícula, dentro de uma população, seja conhecida, ou ainda através de simulação em computador, em partículas virtuais. Maiores detalhes podem ser encontrados em King 1978, King 1979, Barbery 1991, King \& Schneider 1993 e King 1994b.

A grande restriçäo que pode ser feita à aplicação da correção estereológica a dados uni- ou bidimensionais de liberação é que a função de tranformação a ser aplicada foi desenvolvida em outros minérios, de textura muito provavelmente diferente, ou então em simulações computacionais. Uma vez que a função de transformação depende exatamente da textura da rocha, dificilmente a correção produzirá um resultado perfeito. Não há, por outro lado, nenhum outro método melhor para medir o 
espectro de liberação de fases de interesse em minério: análises ao microscópio óptico (em grãos, lâminas delgadas ou secções polidas) são apenas uma simplificação da análise de imagem digital aqui aplicada (de dimensão zero, necessitando igualmente de correções estereológicas), e análises quimicas em produtos de ensaios com líquidos densos fornecem apenas uma aproximação de um valor de grau de liberação, que pode ou não ser real, dependendo das densidades dos minerais do minério e dos líquidos utilizados, e do número de fases. Num minério de duas fases a aproximação pode ser boa, se forem escolhidas densidades adequadas. Assim, uma densidade apenas levemente superior à da fase mais leve deverá produzir um flutuado composto praticamente por $100 \%$ do mais leve. Se o afundado dessa operação for submetido a outros ensaios, com líquidos de densidade progressivamente mais elevada, até que se chegue num afundado composto por praticamente $100 \%$ da fase mais pesada, então o balanço de massa final do conjunto dessas operações será um espectro de liberação desse minério, que, se for acompanhado por análises químicas, poderá ser superior ao calculado por análise de imagens com correção estereológica (mas a função de transformação pode ser facilmente obtida nesse minério, também). Se, ao invés de duas fases, o minério for composto por mais de duas, o método novamente não funciona (a não ser para eventual informação pontual, quando a fase de interesse é a única a afundar ou flutuar, e o líquido utilizado tiver densidade próxima à da fase pura), uma vez que grãos mistos podem ter a mesma densidade aparente de gräos liberados de outra composição. Mesmo a informação pontual, que pode ser de grande interesse para a caracterização da amostra, é geralmente difícil de ser produzida, uma vez que os líquidos densos de uso possível (em termos de custos e operação segura em rotina) têm densidade máxima de 3,32 (iodeto de metileno), baixa para a grande maioria dos minerais de minério. Existem algumas alternativas tecnológicas para produzir 
ambientes de densidade superior (por exemplo, combinando centrifugação com líquidos magnéticos sob campo - Magstream - Salum \& Peres 1998, Schneider 1995), mas os problemas de operação e as grandes limitações que o uso consciente impõe impede que seja solução a não ser em casos específicos. Outra possibilidade são as suspensões coloidais de materiais de alta densidade em líquidos à base de água, que são recentes e ainda devem ser melhor avaliadas. O uso de suspensão de carbeto de tungstênio em solução de politungstato de sódio, por exemplo, está sendo testado pelo CETEM, mas certamente existem problemas de operação e o custo é elevado, principalmente se o sólido micronizado e o líquido não puderem ser recuperados a contento.

Como foi dito antes, o grande questionamento que se faz, hoje, à correção estereológica advém do número limitado de funções de transformação disponíveis que podem ser utilizadas. Considerando-se que não é possivel obter uma função própria para os minérios em estudo, uma vez que não é possível obter concentrados onde todas as partículas têm o mesmo teor conhecido de monazita, é necessário então selecionar uma função que seja a mais adequada entre as que estão disponiveis. Todas elas estão incluídas no software Invert, também de autoria de King \& Schneider, e a seleção da mais apropriada é feita interativamente, por meio de curvas-L ( $L$-curves de Hansen), que calcula resíduo e entropia da inversão estereológica usando os dados a serem corrigidos e as funções de transformação selecionadas. A melhor função é a que apresenta simultaneamente o menor resíduo e o menor módulo de entropia. A melhor funçao é selecionada para cada conjunto de imagens analisadas, ou seja, para cada classe granulométrica, uma vez que a textura varia com o detalhamento obtido com diferentes aumentos. 
Uma vez selecionada a função de transformação mais apropriada, são executados os recálculos dos espectros de liberação linear aparente para volume, e, a partir das densidades da monazita e da sua ganga, liberação em massa. No caso das amostras de minério silexítico de Catalão, foi utilizada a densidade de 5,2 para monazita, e 2,7 para ganga, que é basicamente quartzo. Tentativamente utilizou-se também densidade 3,0 para a ganga (considerando por volta de $10 \%$ de minerais de $\mathrm{Fe}$ ), mas as diferenças são infimas, de maneira que se pode afirmar que essa aproximação causa um erro relativamente muito pequeno. No caso do minério laterítico, há uma grande diversidade na mineralogia da ganga, e a determinação de uma densidade única para recálculo de volume para massa é complicada. Foram, então, utilizadas diversas densidades, entre 3,0 e 4,0, e novamente as mudanças no espectro de liberação em massa foram muito pequenas, de maneira os resultados em massa puderam ser apresentados apesar dessa incerteza. A densidade aplicada à ganga foi 3,5 , uma vez que as fases ferruginosas hidratadas (limonita) são a ganga principal, e assume densidade de 3,8 para ela, mas apatita de densidade 3,15 também é importante.

Com a distribuição de teores para cada tamanho de particula e a distribuição granulométrica calcula-se o espectro de liberação da amostra, que é uma distribuição bivariada que fornece a fração em massa de partículas que apresentam uma combinação específica de tamanho e teor. É calculada multiplicando-se a fração em massa de determinada classe granulométrica pela respectiva distribuição de volume recalculada para massa. Obviamente o espectro de liberação depende da dístribuição granulométrica, e varia se a distribuiçao de tamanho de partícula variar. Como foi calculado a partir da análise granulométrica obtida da amostra, é conhecido como espectro de liberação natural da monazita nos dois tipos de minério, apesar do conceito 
de liberação "natural" no minério silexítico ser algo improvável. Assim, liberação dita natural nesse trabalho equivale à liberação obtida com o processamento das amostras conforme descrito. A partir do espectro de liberação bivariada da amostra pode-se projetar o seu comportamento em hipotéticos ensaios de separação, sempre supondose separação perfeita.

\section{Estimativa de liberação em amostra não quebrada - minério carbonatítico}

Além das vantagens já enumeradas dos dados de intercepto linear, como medida fáceis, acuradas e não-ambiguas, utilizando sistemas de análise de imagem padrão, a mudança de mineral de interesse para ganga pode gerar um ponto numa reta associado à mudança de fase, no sinal utilizado na medida (tipicamente sinal do detector de elétrons retro-espalhados). Como os limites de fases a serem interceptados posicionam-se aleatoriamente ao longo da reta, o sinal pode ser modelado por um processo estocástico desenvolvido em funçăo da distância ao longo da reta (King $1994 a)$

A equação que permite a inversão estereológica em amostras já fragmentadas em partículas de tamanho $\mathrm{D}$ é

$$
P\left(g_{L} \mid D\right)=\int_{0}^{1} P\left(g_{L} \mid g\right) p(g \mid D) d g \quad \text { (repetição da Equação 3.2). }
$$

Para aplicar o modelo linear estocástico (King 1994a) é necessário derivar $P\left(g_{L} \mid \ell\right)$ primeiro, e depois aplicar 


$$
P\left(g_{L} \mid D\right)=\int_{0}^{1} P\left(g_{L} \mid \ell, D\right) p_{p}(\ell \mid D) d \ell
$$

Equação 3.3

onde gt e g ainda são, respectivamente, o teor linear medido num intersecto da partícula e o teor em volume da partícula, $\ell$ é o comprimento de um segmento específico, $p_{p}(\ell \mid D)$ é a distribuição de comprimentos de fragmentos através das partículas de tamanho $\mathrm{D}$, equivalente a

$$
\begin{aligned}
p_{p}(\ell \mid D) & =1-\left(1-\frac{\ell}{1,2 D}\right) \exp \left(-\frac{\ell}{1,2 D}\right) \text { para } \ell \leq 1,2 D \\
& =1 \text { para } \ell>1,2 D
\end{aligned}
$$

Equação 3.4

e assumindo-se $P\left(g_{L} \mid \ell, D\right)=P\left(g_{L} \mid \ell\right)$

A distribuição em volume do teor (em volume) do mineral de interesse na população, $p(g \mid D)$, resulta da solução da integral da Equação 3.3 , e o espectro de liberação de toda a população de partículas produzidas $P(g)$ pode ser obtido se a distribuição de tamanho de partículas produzidas por cominuição, $f(D)$, pode ser predita

$$
P(g)=\int_{0}^{\infty} P(g \mid D) f(D) d D
$$

Equação 3.6

A predição da distribuição dos tamanhos das partículas foi intensamente estudada, e existem diversas soluçöes disponiveis. 
Um requisito à aplicação da metodologia é que a distribuição de comprimentos de interceptos de fase de interese e de ganga deve ser modelada por exponenciais, que são calculadas a partir da distribuição medida de interceptos.

O único dado necessário ao cálculo da previsão de liberação é a liberação linear aparente, ou distribuição de interceptos lineares entre fase de interesse e ganga, no caso de minérios bifásicos. Assim, uma amostra polida do minério carbonatítico foi utilizada para obtenção das imagens para medidas de intercepto linear. Como os interceptos de ganga são muito longos, e com certa freqüência ultrapassam os limites da imagem (distorcendo os dados, uma vez que não se sabe seu comprimento correto), foram obtidas imagens perfeitamente contíguas, que foram emendadas, 10 imagens lateralmente de cada vez, gerando mega-imagens de 9999 por 750 pixels.

Foram adquiridas 60 imagens de elétrons retro-espalhados, a 150, 520 e 1.500 vezes de aumento, representando uma resolução de, respectivamente, 2030, 584,9 e $202,54 \mathrm{~nm} / \mathrm{pixel}$. Essas 180 imagens foram emendadas em 18 mega-imagens ( 3 sets de 6 mega-imagens) manualmente, utilizando uma versăo especialmente desenvolvida para esse fim do software de análise de imagens MMIA, baseando-se na superposição das imagens que permite uma emenda perfeita. Cada set de imagens foi então processada e medida seguindo o seguinte roteiro:

1- Aplicação de filtro de delineação e definição de borda Sobel $3 \times 3$. Esse filtro utilizando apenas as vizinhanças mais imediatas do pixel em questão foi selecionado por ser mais preciso em partículas muito finas da ordem de alguns pixels, uma vez que no menor aumento a monazita frequentemente é muito fina; 
2- Segmentação da monazita, gerando imagem binária. Para tal, foram selecionados valores de niveis de cinza mínimo e máximo ainda durante a preparação da aquisição de imagens, uma vez que pirita e estroncianita apresentam níveis de cinza muito próximos à da monazita. Para melhor segmentação, foi necessário colocar todos os carbonatos e silicatos no nivel de cinza mínimo, ou seja, 0, e pirocloro e barita, mais claros, no máximo, 255. Mesmo assim, no maior aumento, a pirita apresentou nivie conflitantes com a monazita, em parte por causa da grande variação de níveis de cinza dessa. Assim, nas imagens em maior magnificação, a pirita foi manualmente elilminada (substituida por pixels com nivel de cinza 0), tarefa muito facilitada pela granulometria relativamente grossa e pelo hábito cúbico do sulfeto, facilmente reconhecivel.

3- Eliminação de artifactos da imagem binária de monazita, utilizando-se EDM em nivel baixo, para eliminar apenas poucos pixels desconexos, provavelmente devidos a ruído e problemas de polimento.

4- Medidas de intercepto, de monazita e ganga, na própria imagem binária.

As tabelas de tamanho de intercepto (em pixel) versus número de interceptos de cada tamanho foram convertidas para tamanho do intercepto em micra, e os dados obtidos para as três magnificações somados e classificados. A distribuição cumulativa relativa dos interceptos $[F(\ell)]$ foi representada graficamente na forma de tamanho dos interceptos (em $\mu \mathrm{m})$ versus 1-F( $\ell$ ), também utilizada para cálculo das esponenciais múltiplas com melhor ajuste à curva medida, por interpolação. A partir das exponenciais múltiplas de monazita e ganga foi calculada a distribuição de teores lineares, a partir da probabilidade que uma intersecção $\ell$ tenha teor linear $g(\ell)$ 
$\left[P\left(g_{l} \mid \ell\right)\right]$, em relação a tamanhos de partícula D (tamanho fixo das partículas, e não classes de tamanho como nos casos anteriores). A partir da distribuição linear, aplicase a correção estereológica (Equação 3.3) utilizando a função de transformação mais apropriada para cada caso, através das L-curves, e procedendo-se como explicado antes para obtenção do espectro de liberação do minério. 


\section{Minério Silexítico}

A Tabela 4.1 apresenta a distribuição de tamanho de particula do minério silexítico (100\% abaixo de $105 \mu \mathrm{m})$, e a Tabela 4.2 a distribuição em leves e pesados, em relação ao bromofórmio de densidade 2,89 .

Tabela 4.1 - Distribuição de tamanho de partícula do minério silexítico (\% massa).

\begin{tabular}{cccc}
\hline $\begin{array}{c}\text { Peneira } \\
(\mu \mathrm{m})\end{array}$ & Retido (\%) & $\begin{array}{c}\text { Retido } \\
\text { Acumulado }(\%)\end{array}$ & $\begin{array}{c}\text { Passante } \\
\text { Acumulado }(\%)\end{array}$ \\
\hline 74 & 22,75 & 22,75 & 77,25 \\
53 & 13,43 & 36,18 & 63,82 \\
44 & 8,47 & 44,65 & 55,35 \\
37 & 5,07 & 49,72 & 50,28 \\
20 & 14,50 & 64,22 & 35,78 \\
-20 & 35,78 & 100,00 & $-\cdots$ \\
\hline
\end{tabular}

Tabela 4.2 - Distribuição por densidade, em relação ao bromofórmio (\% massa).

\begin{tabular}{ccc}
\hline Fração $(\mu \mathrm{m})$ & Flutuado & Afundado \\
\hline $105 \times 74$ & 46,50 & 53,50 \\
$74 \times 53$ & 51,62 & 48,38 \\
$53 \times 44$ & 51,98 & 48,02 \\
$44 \times 37$ & 26,82 & 73,18 \\
$37 \times 20$ & 0,82 & 99,18 \\
\hline
\end{tabular}

A Tabela 4.3 quantifica a separação por suscetibilidade magnética e a Tabela 4.4 relaciona todas as frações e seus produtos à amostra de cabeça. As Tabelas 4.5 a 4.9 apresentam os resultados de análises químicas $\left(\mathrm{TR}_{2} \mathrm{O}_{3}\right.$ e $\mathrm{Fe}_{2} \mathrm{O}_{3}$ total) de todos os produtos com quantidade suficiente para análise, e quanto isso representa dentro da fração granulométrica e da amostra de cabeça, levando-se em conta os balanços das Tabelas 4.1 a 4.4. Os totais por produto, fração e amostra representam, respectivamente, os teores medidos na fração (análise granuloquímica), o teor calculado para a fração a partir das análises apresentadas e quanto a fração contribui para o teor da cabeça composta. As Tabelas 4.10 e 4.11 , por sua vez, organizam 
melhor esses dados, mostrando o balanço metalúrgico para $\mathrm{TR}_{2} \mathrm{O}_{3}$ e $\mathrm{Fe}_{2} \mathrm{O}_{3}$ de todo o minério silexítico. $\mathrm{O}$ teor de $\mathrm{TR}_{2} \mathrm{O}_{3}$ medido na amostra de cabeça do minério silexítico é de 10,05\% (análise independente de outra aliquota 10,24\%), e nos finos (abaixo de 20 $\mu \mathrm{m}$ ) é de $13,30 \%$ (e $12,43 \%$ ), em massa. $\mathrm{Fe}_{2} \mathrm{O}_{3}$, por sua vez, foi medido como $7,0 \%$ na amostra de cabeça, e $8,10 \%$ nos finos.

Tabela 4.3 - Distribuição por suscetibilidade magnética das frações afundadas minério silexítico (\% em massa, condicional por tamanho).

\begin{tabular}{lccccc}
\hline $\begin{array}{c}\text { Fração } \\
(\mu \mathrm{m})\end{array}$ & $105 \times 74$ & $74 \times 53$ & $53 \times 44$ & $44 \times 37$ & $37 \times 20$ \\
\hline Mag. Imã mão & 5,5 & 8,5 & 5,2 & 6,3 & 0,2 \\
Mag. 0,3 A & 1,6 & 1,1 & 2,0 & 0,9 & 0,7 \\
Mag. 0,5 A & 2,2 & 1,3 & 2,1 & 1,2 & 0,5 \\
Mag. 0,8 A & 11,3 & 5,8 & 3,8 & 6,2 & 1,4 \\
Mag. 1,0 A & 17,7 & 16,2 & 10,9 & 8,7 & 2,8 \\
Mag. 1,5 A & 23,3 & 43,4 & 57,0 & 32,3 & 77,8 \\
Mag. 1,85 A & 21,6 & 16,7 & 1,4 & 9,1 & 11,9 \\
Não Mag. 1,85 A & 16,8 & 6,9 & 17,4 & 35,3 & 4,8 \\
\hline Total & 100,0 & 100,0 & 100,0 & 100,0 & 100,0 \\
\hline
\end{tabular}

Tabela 4.4 - Distribuiçăo por densidade e por suscetibilidade magnética das fraçōes acima de $20 \mu \mathrm{m}$, minério silexítico (\% em massa, em relação ao total da amostra). Fração $-20 \mu$ corresponde aos $35,78 \%$ restantes.

\begin{tabular}{lcccccc}
\hline $\begin{array}{c}\text { Fração } \\
(\mu \mathrm{m})\end{array}$ & $105 \times 74$ & $74 \times 53$ & $53 \times 44$ & $44 \times 37$ & $37 \times 20$ & Total \\
\hline Flutuado & 10,58 & 6,93 & 4,41 & 1,36 & 0,12 & $\mathbf{2 3 , 3 9}$ \\
Af. Mag. Imã mão & 0,67 & 0,55 & 0,21 & 0,23 & 0,03 & $\mathbf{1 , 6 9}$ \\
Af̂. Mag. 0,3 A & 0,20 & 0,07 & 0,08 & 0,03 & 0,10 & $\mathbf{0 , 4 9}$ \\
Ar̂.Mag. 0,5 A & 0,27 & 0,08 & 0,09 & 0,04 & 0,07 & $\mathbf{0 , 5 5}$ \\
Af. Mag. 0,8 A & 1,37 & 0,38 & 0,16 & 0,23 & 0,20 & $\mathbf{2 , 3 3}$ \\
Af. Mag. 1,0 A & 2,16 & 1,05 & 0,44 & 0,32 & 0,40 & $\mathbf{4 , 3 8}$ \\
Af. Mag. 1,5 A & 2,83 & 2,82 & 2,32 & 1,20 & 11,18 & $\mathbf{2 0 , 3 5}$ \\
Af. Mag. 1,85 A & 2,63 & 1,09 & 0,06 & 0,34 & 1,70 & $\mathbf{5 , 8 2}$ \\
Af. Não Mag. 1,85 A & 2,05 & 0,45 & 0,71 & 1,31 & 0,69 & $\mathbf{5 , 2 1}$ \\
\hline \multicolumn{1}{c}{ Total } & $\mathbf{2 2 , 7 5}$ & $\mathbf{1 3 , 4 3}$ & $\mathbf{8 , 4 7}$ & $\mathbf{5 , 0 7}$ & $\mathbf{1 4 , 5 0}$ & $\mathbf{6 4 , 2 2}$ \\
\hline
\end{tabular}


Tabela 4.5 - Teor de $\mathrm{TR}_{2} \mathrm{O}_{3}$ e $\mathrm{Fe}_{2} \mathrm{O}_{3}$ (total), em \% em massa, na fração $105 \times 74 \mu \mathrm{m}$, e balanço de distribuição dos elementos na fração e na amostra total.

\begin{tabular}{lcccccc}
\hline Produto & \multicolumn{3}{c|}{$\mathrm{TR}_{2} \mathrm{O}_{3}$} & \multicolumn{3}{c}{$\mathrm{Fe}_{2} \mathrm{O}_{3}$} \\
& No produto & $\mathrm{Na}$ fração & $\mathrm{Na}$ amostra & No produto & $\mathrm{Na}$ fração & Na amostra \\
\hline Flutuado & 2,69 & 1,25 & 0,28 & 3,56 & 1,66 & 0,38 \\
Imã de Mão & 8,81 & 0,26 & 0,06 & 17,63 & 0,52 & 0,12 \\
0,3 A & 9,91 & 0,09 & 0,02 & 11,27 & 0,10 & 0,02 \\
0,5 A & 2,73 & 0,03 & 0,01 & 56,94 & 0,67 & 0,15 \\
0,8 A & 10,66 & 0,64 & 0,15 & 14,67 & 0,88 & 0,20 \\
1,0 A & 12,13 & 1,15 & 0,26 & 10,36 & 0,98 & 0,22 \\
1,5 A & 14,08 & 1,75 & 0,40 & 4,69 & 0,58 & 0,13 \\
1,85 A & 13,68 & 1,58 & 0,36 & 5,47 & 0,63 & 0,14 \\
Não-Magnético & 12,43 & 1,12 & 0,25 & 3,68 & 0,33 & 0,08 \\
\hline Total & 7,90 & 7,87 & 1,79 & 6,81 & 6,36 & 1,45 \\
\hline
\end{tabular}

Tabela 4.6 - Teor de $\mathrm{TR}_{2} \mathrm{O}_{3}$ e $\mathrm{Fe}_{2} \mathrm{O}_{3}$ (total), em \% em massa, na fração $74 \times 53 \mu \mathrm{m}$, e balanço de distribuição dos elementos na fração e na amostra total.

\begin{tabular}{|c|c|c|c|c|c|c|}
\hline Produto & No produto & $\begin{array}{l}\mathrm{TR}_{2} \mathrm{O}_{3} \\
\mathrm{Na} \text { fraçäo }\end{array}$ & $\mathrm{Na}$ amostra & No produto & $\begin{array}{c}\mathrm{Fe}_{2} \mathrm{O}_{3} \\
\mathrm{Na} \text { fração }\end{array}$ & $\mathrm{Na}$ amostra \\
\hline Flutuado & 3,67 & 1,89 & 0,25 & 3,49 & 1,80 & 0,24 \\
\hline Imã de Mão & 8,05 & 0,33 & 0,04 & 13,78 & 0,57 & 0,08 \\
\hline $0,3 \mathrm{~A}$ & 8,73 & 0,05 & 0,01 & 16,42 & 0,09 & 0,01 \\
\hline $0,5 \mathrm{~A}$ & 3,20 & 0,02 & 0,00 & 48,50 & 0,30 & 0,04 \\
\hline $0,8 \mathrm{~A}$ & 3,75 & 0,11 & 0,01 & 39,43 & 1,11 & 0,15 \\
\hline $1,0 \mathrm{~A}$ & 14,18 & 1,11 & 0,15 & 9,00 & 0,71 & 0,09 \\
\hline $1,5 \mathrm{~A}$ & 14,06 & 2,95 & 0,40 & 4,38 & 0,92 & 0,12 \\
\hline $1,85 \mathrm{~A}$ & 13,19 & 1,07 & 0,14 & 3,80 & 0,31 & 0,04 \\
\hline Não-Magnético & 7,45 & 0,25 & 0,03 & 1,03 & 0,03 & 0,00 \\
\hline Total & 8,03 & 7,78 & 1,04 & 6,75 & 5,84 & 0,78 \\
\hline
\end{tabular}


Tabela 4.7 - Teor de $\mathrm{TR}_{2} \mathrm{O}_{3}$ e $\mathrm{Fe}_{2} \mathrm{O}_{3}$ (total), em \% em massa, na fração $53 \times 44 \mu \mathrm{m}$, e balanço de distribuição dos elementos na fração e na amostra total.

\begin{tabular}{lccc|ccc}
\hline Produto & \multicolumn{3}{c|}{$\mathrm{TR}_{2} \mathrm{O}_{3}$} & \multicolumn{3}{c}{$\mathrm{Fe}_{2} \mathrm{O}_{3}$} \\
& No produto & $\mathrm{Na}$ fração & Na amostra & No produto & $\mathrm{Na}$ fração & Na amostra \\
\hline Flutuado & 4,94 & 2,57 & 0,22 & 3,85 & 2,00 & 0,17 \\
Imã de Mão & 8,67 & 0,22 & 0,02 & 19,48 & 0,49 & 0,04 \\
0,3 A & 8,54 & 0,08 & 0,01 & 18,68 & 0,18 & 0,02 \\
0,5 A & 4,66 & 0,05 & 0,00 & 35,56 & 0,36 & 0,03 \\
0,8 A & 4,25 & 0,08 & 0,01 & 44,88 & 0,82 & 0,07 \\
1,0 A & 12,65 & 0,66 & 0,06 & 9,68 & 0,51 & 0,04 \\
1,5 A & 7,83 & 2,14 & 0,18 & 5,23 & 1,43 & 0,12 \\
1,85 A & 5,12 & 0,04 & 0,00 & 3,92 & 0,03 & 0,00 \\
Não-Magnético & 3,06 & 0,26 & 0,02 & 1,43 & 0,12 & 0,01 \\
\hline Total & 8,04 & 6,09 & 0,52 & 6,62 & 5,95 & 0,50 \\
\hline
\end{tabular}

Tabela 4.8 - Teor de $\mathrm{TR}_{2} \mathrm{O}_{3}$ e $\mathrm{Fe}_{2} \mathrm{O}_{3}$ (total), em \% em massa, na fração $44 \times 37 \mu \mathrm{m}$, e balanço de distribuição dos elementos na fração e na amostra total.

\begin{tabular}{lccc|ccc}
\hline Produto & \multicolumn{3}{c|}{$\mathrm{TR}_{2} \mathrm{O}_{3}$} & \multicolumn{3}{c}{$\mathrm{Fe}_{2} \mathrm{O}_{3}$} \\
& No produto & $\mathrm{Na}$ fração & Na amostra & No produto & Na fração & Na amostra \\
\hline Flutuado & 8,34 & 2,24 & 0,11 & 3,50 & 0,94 & 0,05 \\
Imã de Mão & 7,53 & 0,35 & 0,02 & 15,65 & 0,72 & 0,04 \\
0,3 A & 7,75 & 0,05 & 0,00 & 14,18 & 0,10 & 0,00 \\
0,5 A & 4,50 & 0,04 & 0,00 & 35,31 & 0,30 & 0,02 \\
0,8 A & 7,22 & 0,33 & 0,02 & 29,93 & 1,36 & 0,07 \\
1,0 A & 13,34 & 0,85 & 0,04 & 10,93 & 0,70 & 0,04 \\
1,5 A & 8,93 & 2,11 & 0,11 & 4,62 & 1,09 & 0,06 \\
1,85 A & 11,28 & 0,75 & 0,04 & 4,30 & 0,29 & 0,01 \\
Não-Magnético & 2,40 & 0,62 & 0,03 & 1,65 & 0,43 & 0,02 \\
\hline Total & 7,76 & 7,34 & 0,37 & 5,95 & 5,92 & 0,30 \\
\hline
\end{tabular}


Tabela 4.9 - Teor de $\mathrm{TR}_{2} \mathrm{O}_{3}$ e $\mathrm{Fe}_{2} \mathrm{O}_{3}$ (total), em \% em massa, na fração $37 \times 20 \mu \mathrm{m}$ e nos finos $(-20 \mu \mathrm{m})$, e balanço de distribuição dos elementos na fração e na amostra total.

\begin{tabular}{lccc|ccc}
\hline Produto & \multicolumn{3}{c|}{$\mathrm{TR}_{2} \mathrm{O}_{3}$} & \multicolumn{3}{c}{$\mathrm{Fe}_{2} \mathrm{O}_{3}$} \\
& No produto & $\mathrm{Na}_{\text {fração }}$ & Na amostra & No produto & $\mathrm{Na}$ fração & Na amostra \\
\hline Flutuado & n.a. & 0,00 & 0,00 & $n . a$. & 0,00 & 0,00 \\
Imã de Mão & 7,40 & 0,02 & 0,00 & 4,37 & 0,01 & 0,00 \\
0,3 A & 9,24 & 0,06 & 0,01 & 15,82 & 0,11 & 0,02 \\
0,5 A & 5,90 & 0,03 & 0,00 & 33,12 & 0,16 & 0,02 \\
0,8 A & 8,00 & 0,11 & 0,02 & 19,41 & 0,27 & 0,04 \\
1,0 A & 9,06 & 0,25 & 0,04 & 11,25 & 0,31 & 0,05 \\
1,5 A & 8,08 & 6,23 & 0,90 & 5,19 & 4,00 & 0,58 \\
1,85 A & 5,94 & 0,70 & 0,10 & 3,92 & 0,46 & 0,07 \\
Não-Magnético & 5,39 & 0,26 & 0,04 & 4,14 & 0,20 & 0,03 \\
\hline Total & 8,03 & 7,66 & 1,11 & 6,58 & 5,52 & 0,80 \\
\hline -20 $\mu$ m & 13,30 & --- & 4,76 & 8,10 & -- & 2,90 \\
\hline
\end{tabular}

Tabela 4.10 - Balanço metalúrgico $\left(\mathrm{TR}_{2} \mathrm{O}_{3}, \%\right.$ massa) para o minério silexítico, e distribuição por tamanho de partícula e densidade e/ou susceptibilidade magnética (negrito, em relação ao total da amostra, itálico, \% massa).

\begin{tabular}{lcccccccc}
\hline $\begin{array}{c}\text { Fração } \\
(\mu \mathrm{m})\end{array}$ & $105 \times 74$ & $74 \times 53$ & $53 \times 44$ & $44 \times 37$ & $37 \times 20$ & -20 & Total & Distr. \\
\hline Flutuado & 0,28 & 0,25 & 0,22 & 0,11 & 0,00 & -- & 0,87 & $\mathbf{9 , 0 7}$ \\
Mag. Imã mão & 0,06 & 0,04 & 0,02 & 0,02 & 0,00 & & 0,14 & 1,47 \\
Mag. 0,3 A & 0,02 & 0,01 & 0,01 & 0,00 & 0,01 & -- & 0,04 & $\mathbf{0 , 4 7}$ \\
Mag. 0,5 A & 0,01 & 0,00 & 0,00 & 0,00 & 0,00 & -- & 0,02 & 0,21 \\
Mag. 0,8 A & 0,15 & 0,01 & 0,01 & 0,02 & 0,02 & -- & 0,20 & 2,08 \\
Mag. 1,0 A & 0,26 & 0,15 & 0,06 & 0,04 & 0,04 & -- & 0,55 & $\mathbf{5 , 7 0}$ \\
Mag. 1,5 A & 0,40 & 0,40 & 0,18 & 0,11 & 0,90 & -- & 1,99 & $\mathbf{2 0 , 7 2}$ \\
Mag. 1,85 A & 0,36 & 0,14 & 0,00 & 0,04 & 0,10 & -- & 0,65 & $\mathbf{6 , 7 3}$ \\
Não Mag. 1,85 A & 0,25 & 0,03 & 0,02 & 0,03 & 0,04 & -- & 0,38 & $\mathbf{3 , 9 5}$ \\
\hline \multicolumn{1}{c}{ Total } & 1,79 & 1,04 & 0,52 & 0,37 & 1,11 & 4,76 & 9,59 & $\mathbf{4 9 , 6 1}$ \\
\hline Distribuição & $\mathbf{1 8 , 6 7}$ & $\mathbf{1 0 , 8 9}$ & $\mathbf{5 , 3 8}$ & $\mathbf{3 , 8 7}$ & $\mathbf{1 1 , 5 7}$ & $\mathbf{4 9 , 6 1}$ & $\mathbf{1 0 0 , 0 0}$ & \\
\hline
\end{tabular}


Tabela 4.11 - Balanço metalúrgico $\left(\mathrm{Fe}_{2} \mathrm{O}_{3}, \%\right.$ massa) para o minério silexítico, e distribuição por tamanho de partícula e densidade e/ou susceptibilidade magnética (negrito, em relação ao total da amostra, itálico, \% massa).

\begin{tabular}{lcccccccc}
\hline $\begin{array}{c}\text { Fração } \\
(\mu \mathrm{m})\end{array}$ & $105 \times 74$ & $74 \times 53$ & $53 \times 44$ & $44 \times 37$ & $37 \times 20$ & -20 & Total & Distr * \\
\hline Flutuado & 0,38 & 0,24 & 0,17 & 0,05 & 0,00 & -- & 0,84 & $\mathbf{1 2 , 4 1}$ \\
Mag. Imã mão & 0,12 & 0,08 & 0,04 & 0,04 & 0,00 & & 0,27 & $\mathbf{4 , 0 5}$ \\
Mag. 0,3 A & 0,02 & 0,01 & 0,02 & 0,00 & 0,02 & -- & 0,07 & $\mathbf{1 , 0 4}$ \\
Mag. 0,5 A & 0,15 & 0,04 & 0,03 & 0,02 & 0,02 & $\ldots$ & 0,26 & $\mathbf{3 , 9 1}$ \\
Mag. 0,8 A & 0,20 & 0,15 & 0,07 & 0,07 & 0,04 & $\ldots$ & 0,53 & $\mathbf{7 , 8 4}$ \\
Mag. 1,0 A & 0,22 & 0,09 & 0,04 & 0,04 & 0,05 & $\ldots$ & 0,44 & $\mathbf{6 , 5 6}$ \\
Mag. 1,5 A & 0,13 & 0,12 & 0,12 & 0,06 & 0,58 & $\ldots$ & 1,01 & $\mathbf{1 5 , 0 5}$ \\
Mag. 1,85 A & 0,14 & 0,04 & 0,00 & 0,01 & 0,07 & $\ldots$ & 0,27 & $\mathbf{3 , 9 9}$ \\
Não Mag. 1,85 A & 0,08 & 0,00 & 0,01 & 0,02 & 0,03 & $\ldots$ & 0,14 & $\mathbf{2 , 0 8}$ \\
\hline Total & 1,45 & 0,78 & 0,50 & 0,30 & 0,80 & 2,90 & 6,73 & $\mathbf{4 3 , 0 5}$ \\
\hline Distribuição & $\mathbf{2 1 , 4 8}$ & $\mathbf{1 1 , 6 4}$ & $\mathbf{7 , 4 9}$ & $\mathbf{4 , 4 6}$ & $\mathbf{1 1 , 8 9}$ & $\mathbf{4 3 , 0 5}$ & $\mathbf{1 0 0 , 0 0}$ & \\
\hline
\end{tabular}

Pelas tabelas acima, pode-se perceber que em geral há um pequeno enriquecimento em terras raras entre 1,0 e 1,5 A, mas que nunca se atinge $15 \%$ de $\mathrm{TR}_{2} \mathrm{O}_{3}$. O ferro, por outro lado, é concentrado em 0,5 a $0,8 \mathrm{~A}$, e pode superar os $50 \%$ de $\mathrm{Fe}_{2} \mathrm{O}_{3}$ em algumas frações mais grossas. $\mathrm{O}$ balanço metalúrgico, no entanto, mostra que não há uma concentração razoável das terras raras ou do $\mathrm{Fe}$, nem em relação à densidade e/ou susceptibilidade magnética, nem em relaçäo à granulometria. A maior concentração $\left(49,61 \%\right.$ dos OTR, mas também $43,05 \%$ do $\left.\mathrm{Fe}_{2} \mathrm{O}_{3}\right)$ está nos finos, cujo teor é de $13,30 \%$ de $\mathrm{TR}_{2} \mathrm{O}_{3}$. Além dos finos, os produtos afundados magnéticos a $1,5 \mathrm{~A}$ concentram pouco mais de $20 \%$ dos OTR, mas representam $20,35 \%$ da amostra, de maneira que a concentração é muito mais produto da alta recuperação de massa do minério nessa intensidade de campo do que de concentração das terras raras. Acompanhando a maior massa recuperada a 1,5 A, o teor de $\mathrm{Fe}_{2} \mathrm{O}_{3}$ também é elevado, $15,05 \%$.

As Tabelas 4.12 a 4.16 apresentam a mineralogia por fração/produto determinada por difração de raios $X$, apenas qualitativamente. A ordem dos minerais identificados reflete a sua quantidade (em ordem decrescente) determinada pelo scaling da altura dos picos pelo software utilizado Geralmente a quantidade de minerais como barita, cerianita (aliás, cerianita $\mathrm{Ce}$, apesar de todas as opçōes serem cerianitam $\mathrm{Ce}$ ), goethita, fluorapatita e hollandita, pelo mesmo scaling (que não representa quantificação real, apenas uma maneira de organizar os dados de forma mais coerente) fica abaixo de $5 \%$ 
Tabela 4.12 - Composição mineralógica, conforme identificada por DRX, da fração $105 \times 74 \mu \mathrm{m}$.

\begin{tabular}{ll}
\hline Produto & \multicolumn{2}{c}{ Mineralogia } \\
\hline Flutuado & $\begin{array}{l}\text { Quartzo, fluorapatita, goethita, monazita-Ce } \\
\text { Imã de Mão } \\
\text { Quartzo, monazita-Ce, goethita, hematita, magnetita, cerianita, } \\
\text { fluorapatita }\end{array}$ \\
0,3 A & Quartzo, monazita-Ce, goethita, fluorapatita, hematita \\
0,5 A & Quartzo, hematita, goethita, monazita-Ce, cerianita (?) \\
0,8 A & Quartzo, monazita-Ce, hematita, goethita, fluorapatita, barita \\
$1,0 \mathrm{~A}$ & Quartzo, monazita-Ce, hematita, goethita, cerianita, fluorapatita, barita \\
$1,5 \mathrm{~A}$ & Quartzo, monazita-Ce, cerianita, fluorapatita, goethita, barita \\
1,85 A & Quartzo, monazita-Ce, cerianita, fluorapatita, goethita \\
Não-Mag. & Quartzo, monazita-Ce, goethita, fluorapatita, cerianita, barita
\end{tabular}

Tabela 4.13 - Composição mineralógica, conforme identificada por DRX, da fração $74 \times 53 \mu \mathrm{m}$.

\begin{tabular}{ll}
\hline Produto & \multicolumn{2}{c}{ Mineralogia } \\
\hline Flutuado & Quartzo, monazita-Ce, goethita, cerianita \\
Imã de Mão & $\begin{array}{l}\text { Quartzo, monazita-Ce, goethita, cerianita, magnetita, hematita, } \\
\text { fluorapatita }\end{array}$ \\
0,3 A & Quartzo, monazita-Ce, goethita, hematita, fluorapatita \\
0,5 A & Quartzo, hematita, goethita, monazita-Ce \\
0,8 A & Quartzo, hematita, goethita, monazitamCe, cerianita \\
1,0 A & Quartzo, monazita-Ce, cerianita, barita, hematita, goethita, fluorapatita \\
$1,5 \mathrm{~A}$ & Quartzo, monazita-Ce, barita, cerianita, fluorapatita \\
1,85 A & Quartzo, monazita-Ce, cerianita, barita, fluorapatita \\
Não-Mag. & Quartzo, monazita-Ce, barita, fluorapatita, cerianita \\
\hline
\end{tabular}



Tabela 4.14 - Composição mineralógica, conforme identificada por DRX, da fração
$53 \times 44 \mu \mathrm{m}$.

\begin{tabular}{ll}
\hline Produto & \multicolumn{1}{c}{ Mineralogia } \\
\hline Flutuado & Quartzo, monazita-Ce, goethita \\
Imã de Mão & Quartzo, goethita, monazita-Ce, hematita, magnetita, fluorapatita, barita \\
0,3 A & Quartzo, monazita-Ce, goethita, hematita, cerianita, fluorapatita \\
0,5 A & Quartzo, monazita-Ce, goethita, hematita, barita, cerianita, fluorapatita \\
0,8 A & Quartzo, goethita, hematita, monazita-Ce, cerianita, fluorapatita \\
1,0 A & Quartzo, monazita-Ce, goethita, barita, fluorapatita \\
1,5 A & Quartzo, monazita-Ce, cerianita, barita, fluorapatita, goethita \\
1,85 A & Quartzo, monazita-Ce, cerianita, barita, fluorapatita, goethita \\
Não-Mag. & Quartzo, barita, monazitamCe, fluorapatita, goethita \\
\hline
\end{tabular}

Tabela 4.15 - Composição mineralógica, conforme identificada por DRX, da fração $44 \times 37 \mu \mathrm{m}$.

\begin{tabular}{ll}
\hline Produto & \multicolumn{1}{c}{ Mineralogia } \\
\hline Flutuado & Quartzo, monazita-Ce, barita, fluorapatita \\
Imã de Mão & $\begin{array}{l}\text { Quartzo, goethita, monazita-Ce, hematita, magnetita, barita, cerianita, } \\
\text { fluorapatita }\end{array}$ \\
0,3 A & Quartzo, goethita, cerianita, monazita-Ce, hematita, fluorapatita, barita \\
0,5 A & Quartzo, hematita, goethita, monazita-Ce, cerianita, fluorapatita \\
0,8 A & Quartzo, hematita, goethita, monazita-Ce, hollandita, cerianita \\
1,0 A & Quartzo, monazita-Ce, goethita, hematita, cerianita, barita, fluorapatita \\
1,5 A & Quartzo, monazita-Ce, goethita, cerianita, barita, fluorapatita \\
1,85 A & Quartzo, monazita-Ce, cerianita, fluorapatita, goethita \\
Não-Mag. & Quartzo, monazita-Ce, barita, fluorapatita, cerianita, goethita \\
\hline
\end{tabular}


Tabela 4.16 - Composição mineralógica, conforme identificada por DRX, da fração
$37 \times 20 \mu \mathrm{m}$, e dos finos $(-20 \mu \mathrm{m})$.

\begin{tabular}{|c|c|}
\hline Produto & Mineralogia \\
\hline Flutuado & Quartzo, monazita-Ce, goethita, fluorapatita \\
\hline Imã de Mão & $\begin{array}{l}\text { Quartzo, Fe metálico, monazita-Ce, magnetita, goethita, cerianita, } \\
\text { hematita, fluorapatita }\end{array}$ \\
\hline $0,3 \mathrm{~A}$ & $\begin{array}{l}\text { Quartzo, monazita-Ce, goethita, cerianita, } \mathrm{Fe} \text { metálico, hematita, } \\
\text { fluorapatita }\end{array}$ \\
\hline $0,5 \mathrm{~A}$ & Quartzo, hematita, goethita, monazita-Ce, fluorapatita, cerianita (?) \\
\hline $0,8 \mathrm{~A}$ & Quartzo, hematita, goethita, monazita-Ce, cerianita, fluorapatita \\
\hline $1,0 \mathrm{~A}$ & Quartzo, monazita-Ce, goethita, hematita, cerianita, fluorapatita \\
\hline $1,5 \mathrm{~A}$ & Quartzo, monazita-Ce, goethita, barita, cerianita, hematita, fluorapatita \\
\hline $1,85 \mathrm{~A}$ & Quartzo, monazita-Ce, goethita, barita, cerianita, fluorapatita \\
\hline Não-Mag. & Quartzo, monazita-Ce, barita, goethita, cerianita, fluorapatita \\
\hline$-0,020 \mathrm{~mm}$ & Quartzo, monazita-Ce, fluorapatita, cerianita, hematita \\
\hline
\end{tabular}

A fase carreadora de ETR mais importante que se encontrou foi a monazita. Ao MEV, a monazita se apresenta de diferentes formas, mas a mais comum são os esferóides concêntricos dispersos na matriz, geralmente de quartzo, mas também de minerais de Fe. As imagens das Figuras 4.1 e 4.2 exemplificam esses esferóides. Além de sua forma de ocorrência esferoidal mais comum, a monazita também ocorre como provável substituição pseudomórfica de outros minerais, como massas mais ou menos maciças e como agulhas. As Figuras 4.3 a 4.7 exemplificam algumas dessas formas. A forma vermiforme mostrada na Figura 4.3 também é comum, mas geralmente os "vermes" de monazita são muito finos, e só são identificados como tal em magnificações maiores. 


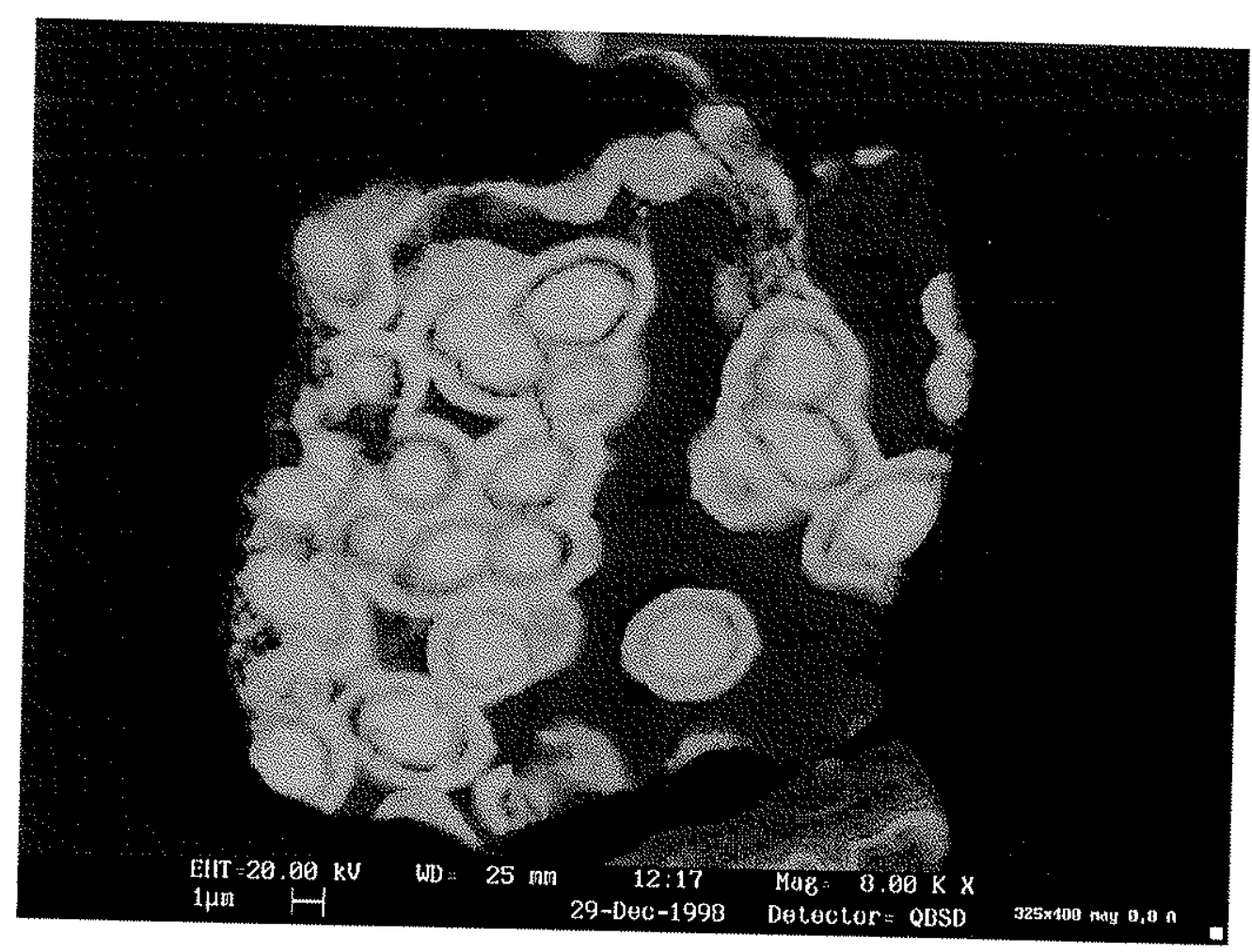
Figura 4.1 - Monazita (mais clara) em esferóides concêntricos na matriz de quartzo
(MEV/BSD).

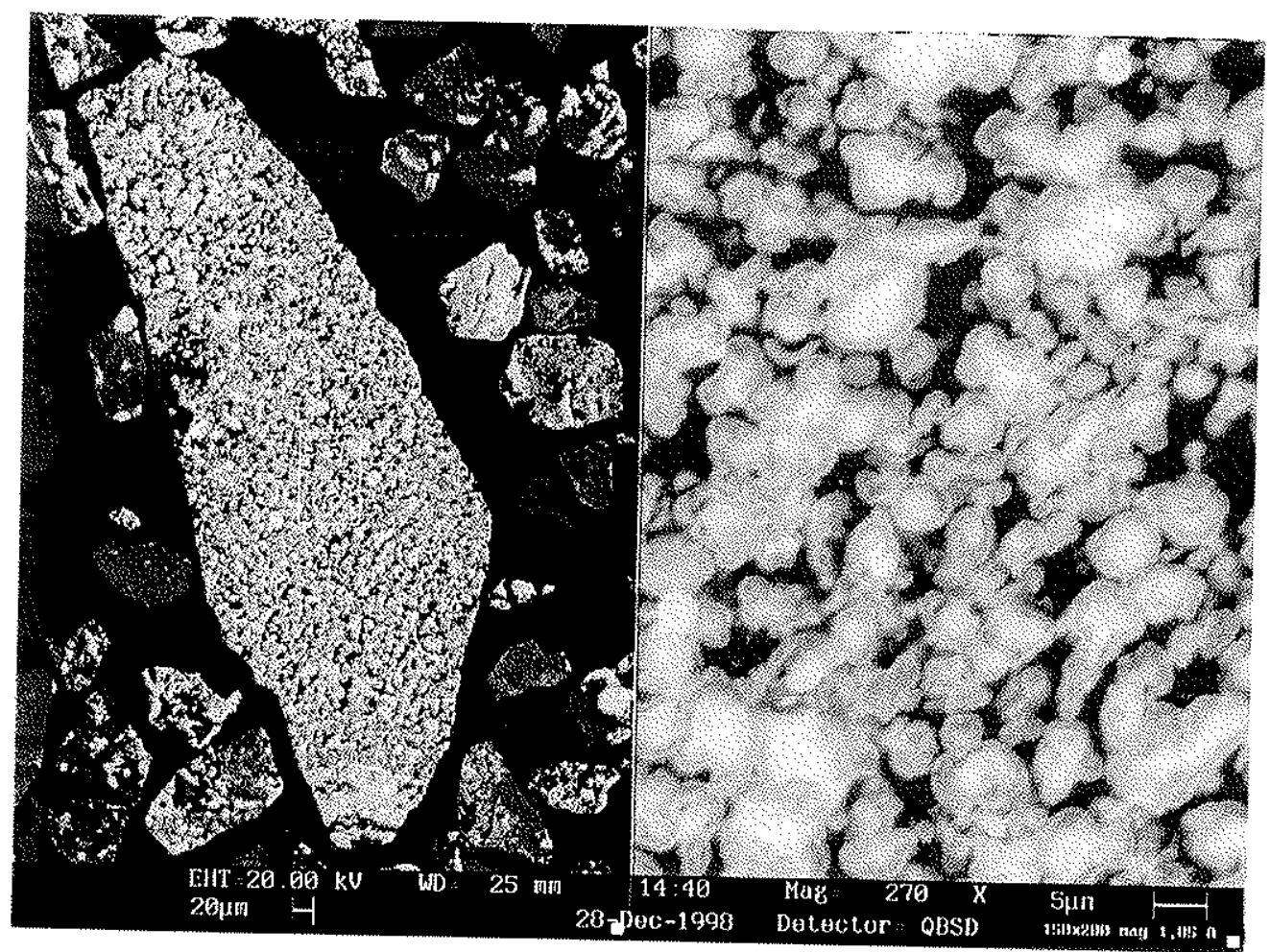
Figura 4.2 - Monazita (mais clara) em esferóides concêntricos na matriz de quartzo
(MEV/BSD). 


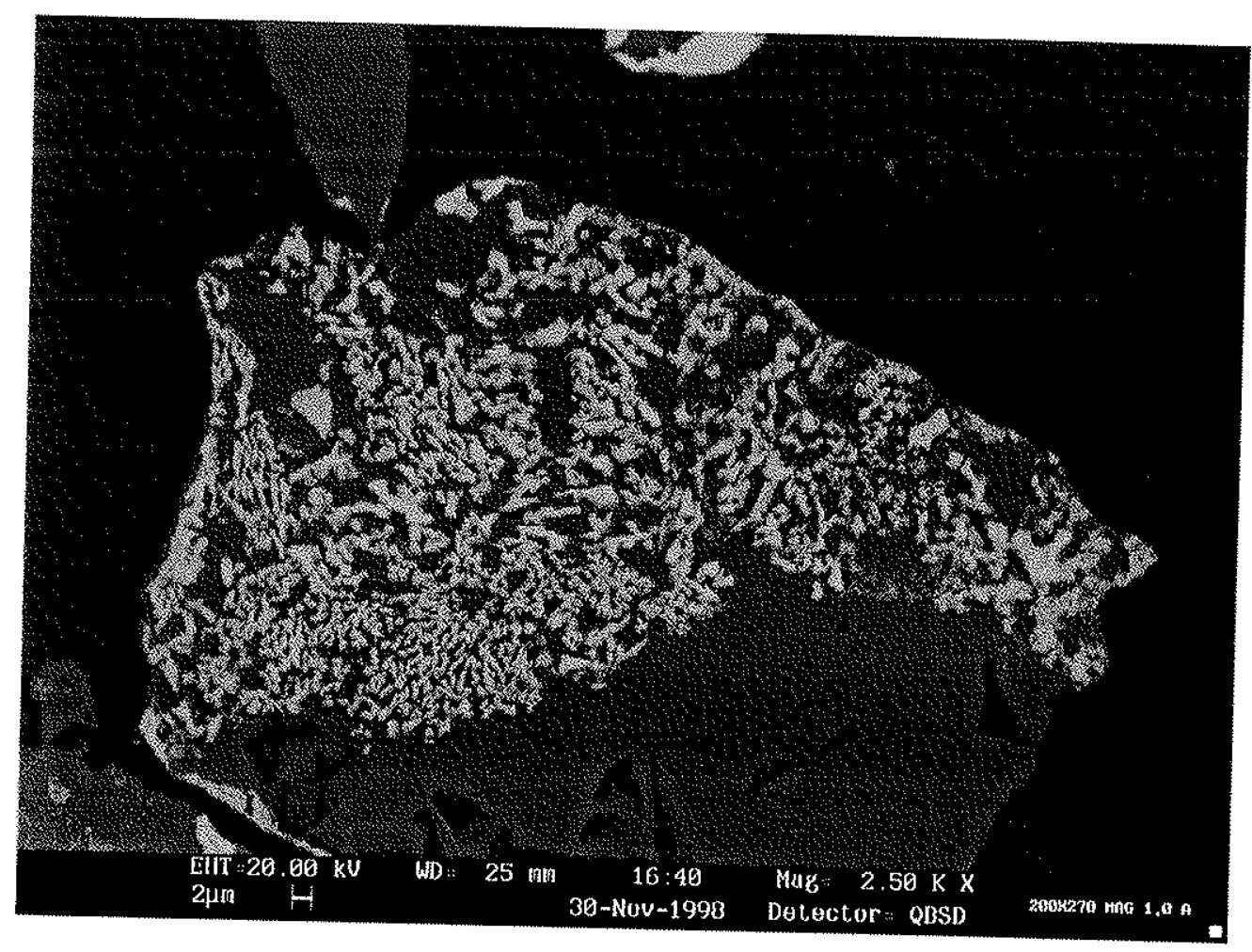

Figura 4.3 - Monazita (mais clara) vermiforme na matriz de quartzo (MEV/BSD).

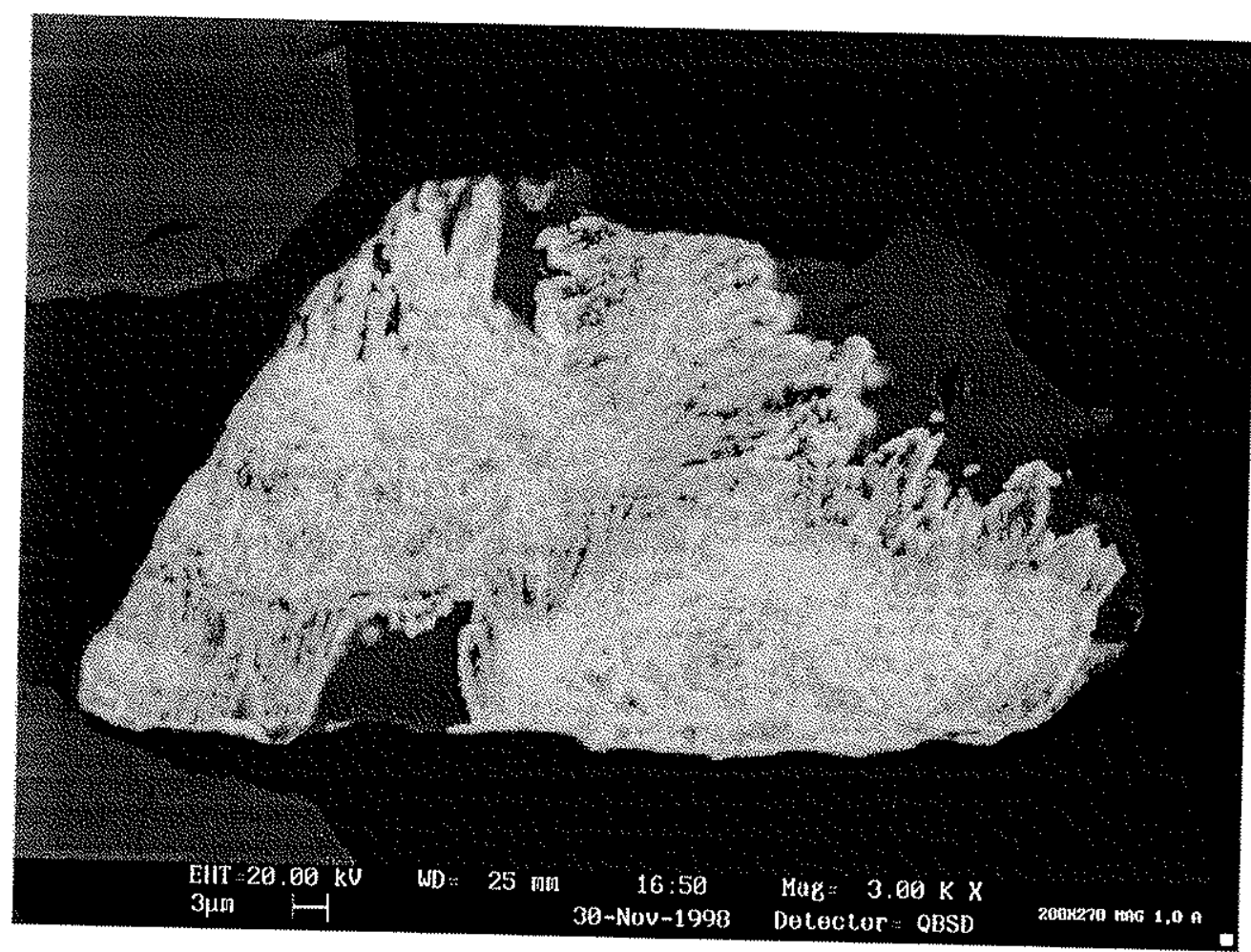
Figura 4.4 - Monazita (mais clara) como massa irregular na matriz de quartzo
(MEV/BSD). 


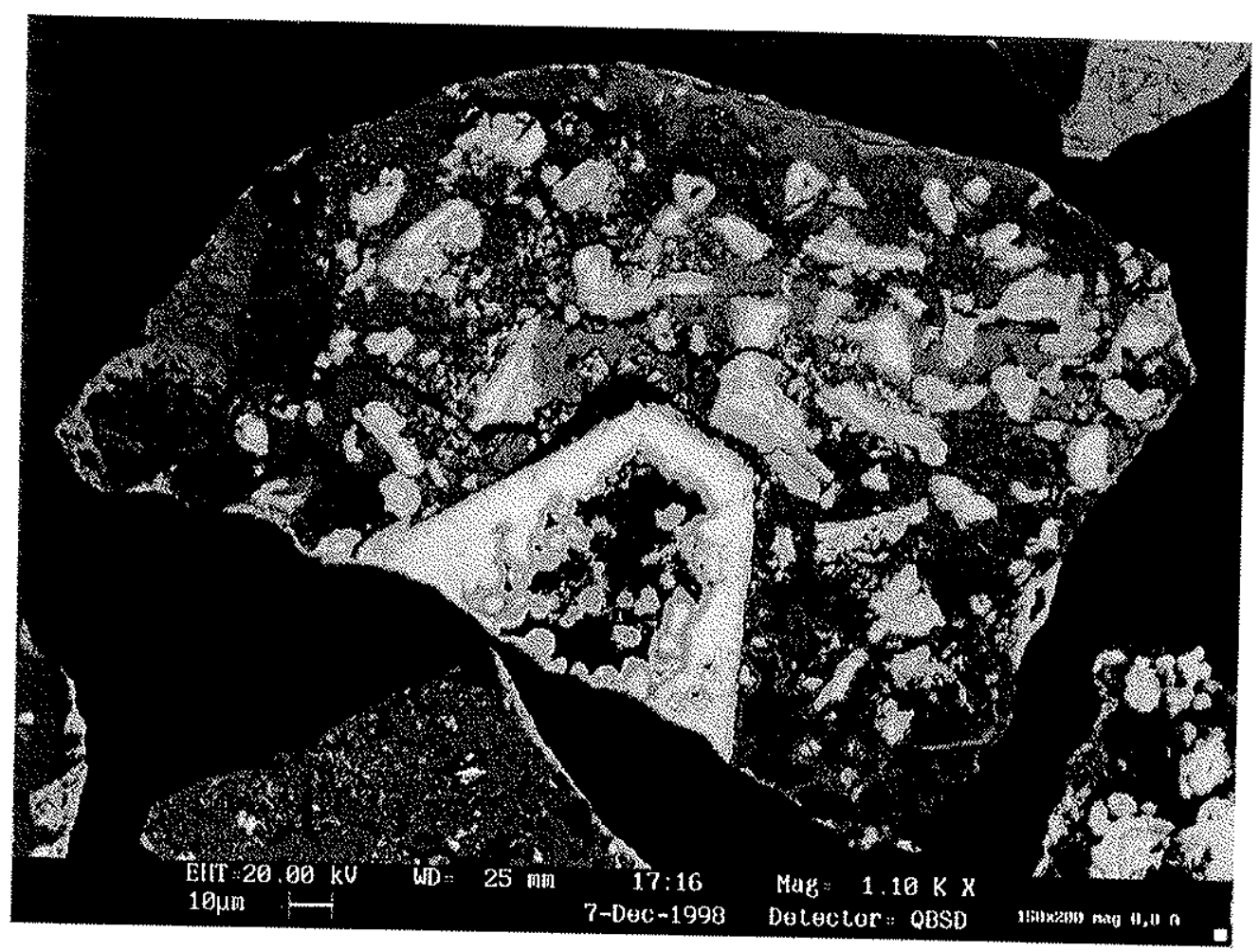

Figura 4.5 - Monazita (mais clara) em esferóides concêntricos, como massas irregulares e como provável pseudomorfo (segundo pirocloro ou apatita?) na matriz de quartzo (MEV/BSD).

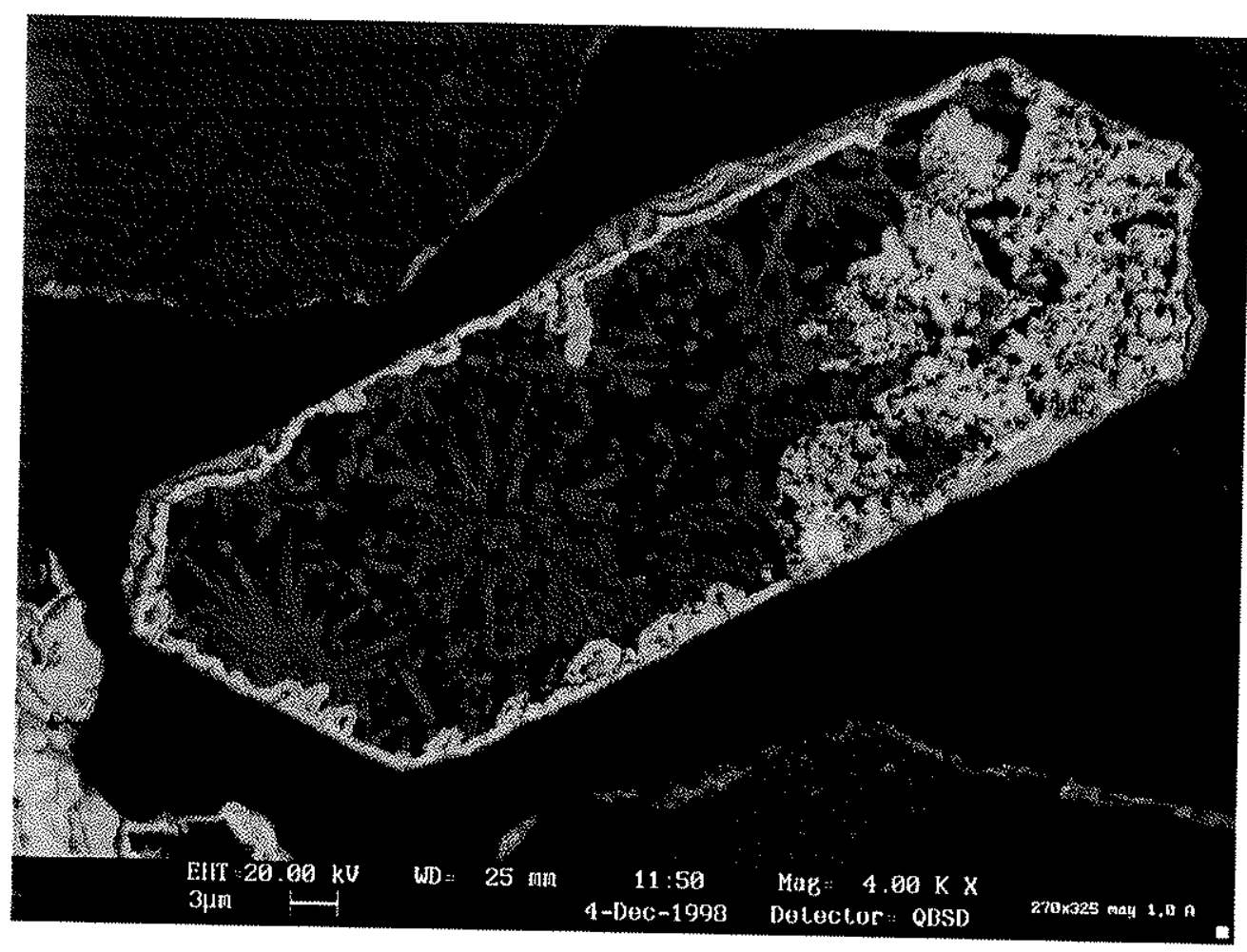

Figura 4.6 - Monazita (mais clara) pseudomorfa mantendo as bordas e preenchendo parcialmente, como massas irregulares, um antigo cristal (apatita?), também preenchido por óxidos/hidróxidos de Fe em cristais aciculares, e quartzo (MEV/BSD). 


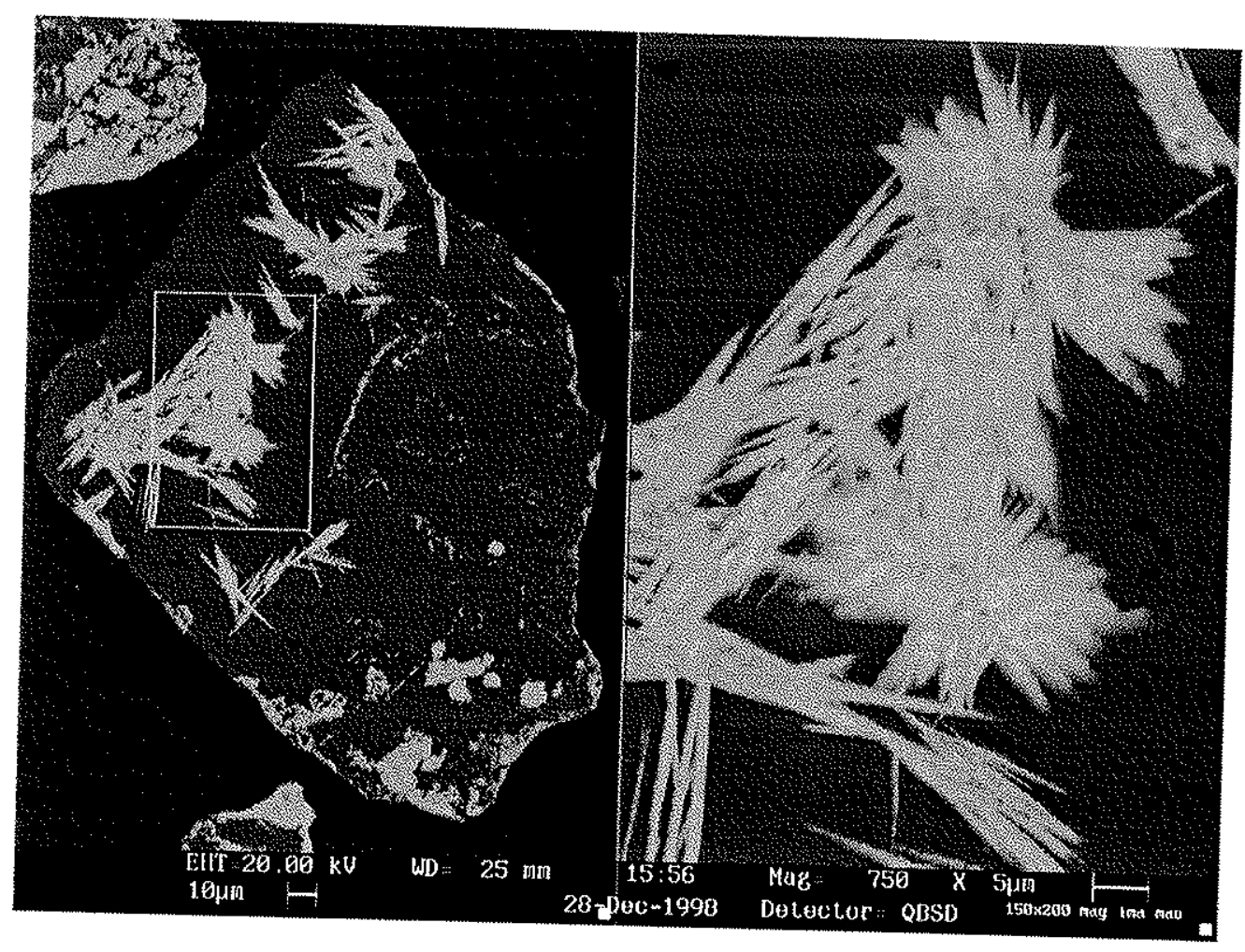
Figura 4.7 - Monazita (mais clara) acicular fibrorradiada na matriz de quartzo, contendo
ainda óxidos/hidróxidos de Fe (MEV/BSD).

A grande variação nos niveis de cinza da monazita, particularmente nos esferóides concêntricos realçando esse seu caráter, foi motivo de muitas discussöes e dúvidas. Morteani \& Preinfalk (1996) identificaram, de maneira qualitativa, camadas de cerianita como responsáveis pelos niveis mais claros. A grande limitação analítica para resolver essa questão é justamente a espessura muito fina das camadas, inferior à resolução dos feixes de elétrons, para análises por EDS ou WDS. Procurou-se encontrar, nesse trabalho, esferóides com camadas de espessura maior, acima dos aproximadamente $2 \mu \mathrm{m}$, que é a área que emite raios $X$ analisados pelo detector. $O$ esferóide da Figura 4.8 é um exemplo desses grãos, e foi analisado com essa finalidade. Os resultados da análise de EDS para análises em três grãos estão na Tabela 4.17. 


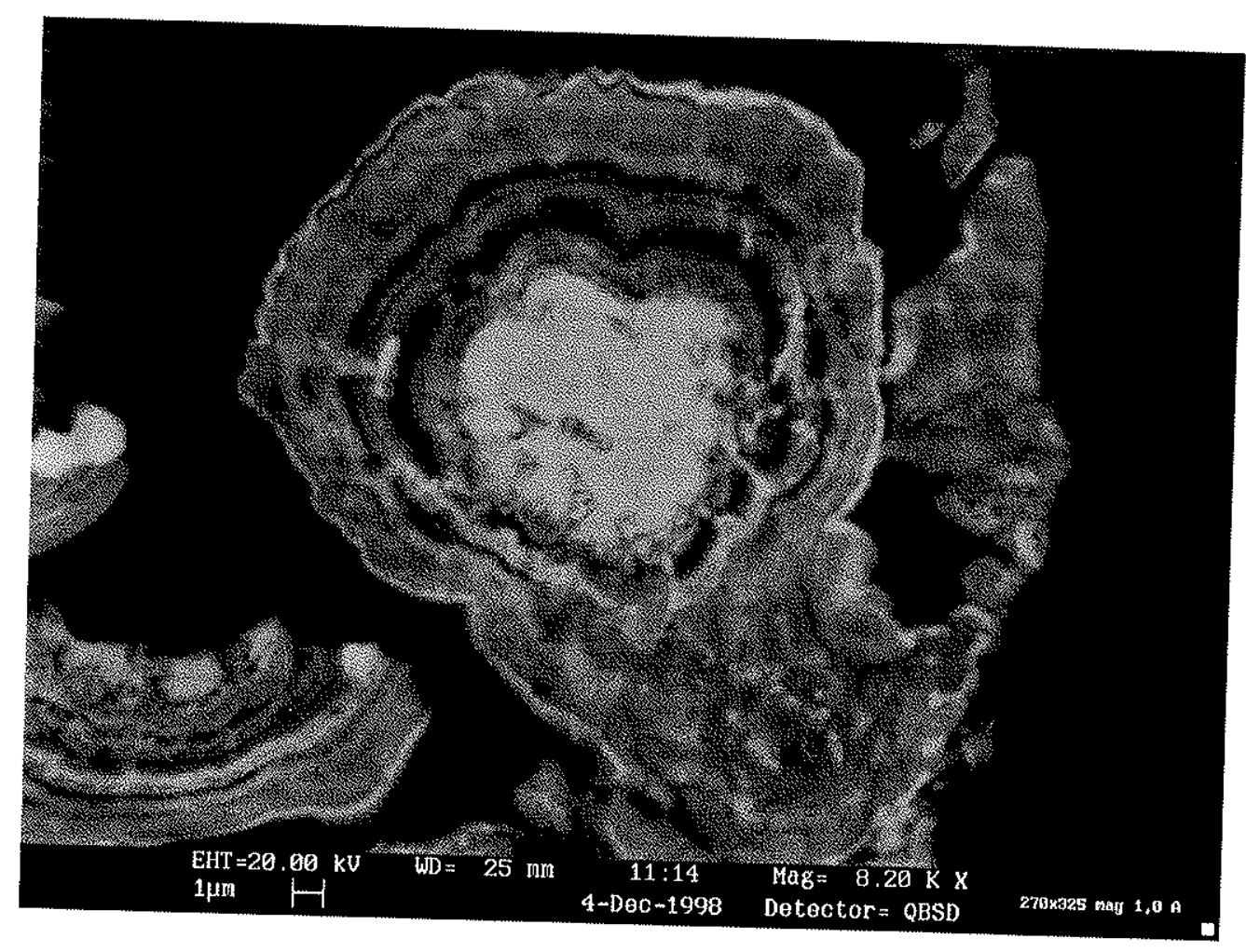

Figura 4.8 - Monazita com diversas tonalidades de nivel de cinza (MEV/BSD).

Tabela 4.17 - Análises comparativas de regiões mais claras e escuras de três grãos onde essas regiões poderiam permitir resolução melhor do detector de EDS (\% em
massa).

\begin{tabular}{lcc|cccc}
\hline & A- Clara & A- Escura & B-Clara & B- Escura & C-Clara & C-Escura \\
\hline $\mathrm{O}$ & 31,7 & 45,4 & 32,3 & 32,2 & 34,5 & 41,3 \\
$\mathrm{Si}$ & 3,7 & 23,2 & 0,4 & 2,2 & 1,6 & 19,9 \\
$\mathrm{P}$ & 14,3 & 7,6 & 15,3 & 15,8 & 14,8 & 8,1 \\
$\mathrm{Ca}$ & 1,7 & 0,9 & 1,8 & 2,2 & 1,7 & 1,0 \\
$\mathrm{Sr}$ & 3,1 & 2,0 & 3,4 & 3,0 & 3,9 & 2,2 \\
$\mathrm{La}$ & 13,9 & 6,1 & 10,5 & 13,2 & 10,7 & 7,3 \\
$\mathrm{Ce}$ & 22,9 & 10,7 & 24,9 & 22,1 & 23,1 & 15,1 \\
$\mathrm{Nd}$ & 8,8 & 4,3 & 11,4 & 9,4 & 9,6 & 5,1 \\
\hline Monazita & $\mathbf{9 2 , 2}$ & $\mathbf{5 0 , 5}$ & $\mathbf{9 9 , 2}$ & $\mathbf{9 5 , 3}$ & $\mathbf{9 6 , 5}$ & $\mathbf{5 7 , 5}$ \\
Quartzo & $\mathbf{7 , 8}$ & $\mathbf{4 9 , 5}$ & $\mathbf{0 , 8}$ & $\mathbf{4 , 7}$ & $\mathbf{3 , 5}$ & $\mathbf{4 2 , 5}$ \\
\hline
\end{tabular}

Apesar das análise serem semiquantitativas, fica muito claro que as regiões mais escuras (e portanto mais leves) contêm um alto teor de sílica, que foi recalculado para quartzo na Tabela 4.17. É muito difícil conseguir uma visualização desse intercrescimento muito fino entre monazita e quartzo, uma vez que as dimensões são da ordem de nanômetros, no limite da capacidade do MEV. A imagem da Figura 4.9 (análise $\mathrm{C}$ da Tabela 4.17) detalha um esferóide da imagem da Figura 4.1, e é visivel 
uma fina trama de monazita dentro de uma matriz escura que deve ser o quartzo, e que gera uma camada com nivel de cinza resultante intermediário entre ambos. Considerando-se que todas as outras possibilidades foram testadas e rejeitadas (troca de ETR por $\mathrm{Ca}$, troca de $\mathrm{Sr}$ por $\mathrm{Ca}$, outros elementos presentes em um e não em outro, etc), algumas camadas muito provavelmente são de monazita + quartzo intercrescidos, informação essa de maior importância para o seu processamento.

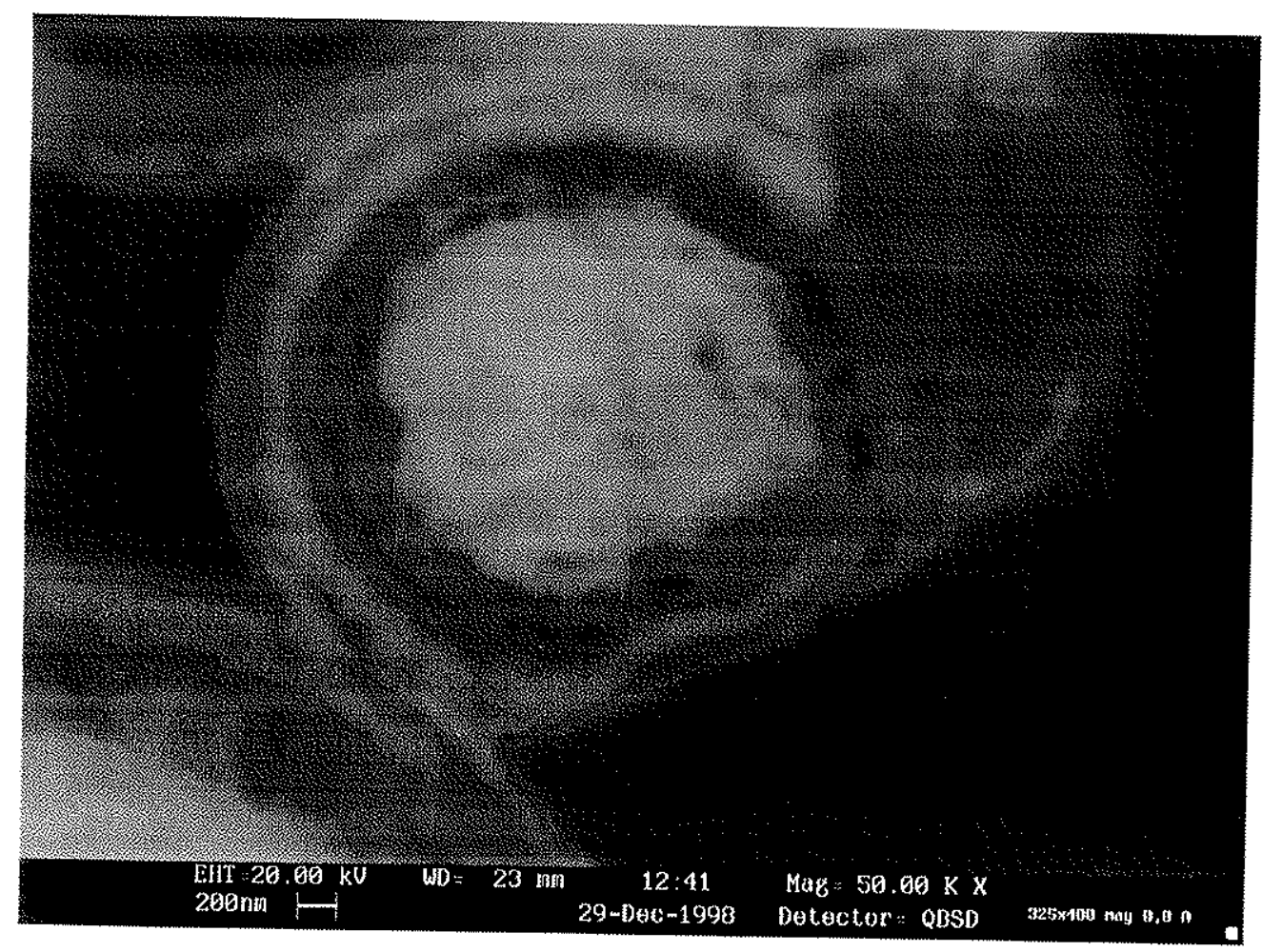

Figura 4.9 - Monazita com diversas tonalidades de nivel de cinza (MEV/BSD). E possivel observar uma fina trama de monazita em matriz mais escura de quartzo nas camadas mais escuras, no esferóide central e inferior esquerdo.

A Tabela 4.18 apresenta a composição de diversos grãos de monazita, sempre medidos por EDS em secções polidas. Apesar de apresentarem fechamento entre $80 \mathrm{e}$ $92 \%$, mantêm relações estequiométricas próximas ao esperado. Pereira (1995) já alertava para a baixa totalização nas análises (no caso, de WDS) de Catalão I. Discussões com outros especialistas (Prof. Dra. Maria Cristina Motta de Toledo) confirmam essa tendência, tentativamente atribuída à alta microporosidade nessas amostras, que permite contagens mais baixas e causa totalização inferior ao esperado. Considerando diversos fatores inerentes às amostras de Catalão I, como tamanho dos grãos extremamente reduzido e intercrescimento nanométrico da monazita com outras 
fases, eventuais análises por metodologia mais apropriada (como WDS) dificilmente gerariam resultadios muito superiores, a não ser que se produzisse um feixe mais fino com uma resolução da imagem semelhante (ou melhor) do que o obtido nesse trabalho. Para apresentação na tabela, foi subtraída dos dados da análise a sílica, e não considerados $\mathrm{Fe}$ e $\mathrm{Mn}$ que podem ocorrer em até 1\% (análises com teores superiores foram descartadas). Algumas análises ainda apresentam flúor, denotando intercrescimento com fluorapatita, mas essas análises também foram descartadas, apesar desse intercrescimento poder acontecer sem que seja nitidamente visualizado.

Tabela 4.18 - Análises químicas pontuais (por EDS, \% em massa) de monazita de Catalão, recalculadas após subtração de sílica. Média em negrito, na última linha.

\begin{tabular}{cccccccc}
\hline $\mathrm{O}$ & $\mathrm{P}$ & $\mathrm{Ca}$ & $\mathrm{Sr}$ & $\mathrm{La}$ & $\mathrm{Ce}$ & $\mathrm{Nd}$ & $\Sigma \mathrm{ETR}$ \\
\hline 31,8 & 15,6 & 1,9 & 3,6 & 18,2 & 23,7 & 5,1 & 47,0 \\
31,3 & 15,4 & 2,2 & 3,0 & 15,3 & 24,6 & 8,3 & 48,2 \\
29,8 & 15,5 & 1,8 & 3,4 & 15,1 & 24,8 & 9,5 & 49,5 \\
30,0 & 15,0 & 2,1 & 2,8 & 16,7 & 29,9 & 3,4 & 50,0 \\
36,0 & 14,5 & 2,0 & 3,5 & 17,5 & 24,7 & 1,8 & 44,0 \\
32,3 & 13,7 & 2,6 & 4,8 & 22,7 & 24,2 & $-0,3$ & 46,6 \\
32,9 & 15,2 & 1,7 & 4,0 & 11,6 & 26,5 & 8,1 & 46,2 \\
25,9 & 16,2 & 2,3 & 2,9 & 14,5 & 29,7 & 8,5 & 52,7 \\
32,8 & 15,4 & 1,8 & 2,5 & 16,4 & 25,3 & 5,9 & 47,5 \\
31,8 & 14,9 & 1,6 & 3,3 & 17,9 & 25,4 & 5,0 & 48,3 \\
32,9 & 15,3 & 1,5 & 4,6 & 11,3 & 25,8 & 8,5 & 45,6 \\
32,1 & 15,4 & 1,8 & 3,4 & 10,6 & 25,1 & 11,5 & 47,3 \\
31,1 & 16,5 & 2,3 & 3,2 & 13,9 & 23,2 & 9,8 & 46,8 \\
33,2 & 13,5 & 2,9 & 3,9 & 20,9 & 23,6 & 2,1 & 46,5 \\
32,3 & 15,4 & 1,9 & 2,9 & 11,6 & 25,1 & 10,9 & 47,6 \\
29,7 & 10,9 & 3,0 & 1,2 & 21,0 & 28,8 & 5,4 & 55,2 \\
33,8 & 15,4 & 1,8 & 4,1 & 11,1 & 23,9 & 10,0 & 45,0 \\
32,3 & 14,9 & 1,9 & 2,5 & 21,6 & 24,1 & 2,8 & 48,5 \\
\hline $\mathbf{3 1 , 8}$ & $\mathbf{1 4 , 9}$ & $\mathbf{2 , 1}$ & $\mathbf{3 , 3}$ & $\mathbf{1 6 , 0}$ & $\mathbf{2 5 , 5}$ & $\mathbf{6 , 5}$ & $\mathbf{4 7 , 9}$ \\
\hline
\end{tabular}

O total de ETR nas monazitas é bem constante, variando de 45 a $55 \%$ em massa, a grosso modo. Em termos de óxidos de terras raras, o total médio é da ordem de $58 \%$, o que é superior às análises de monazita separada manualmente de Imbernon (1993), mas na análise da autora os óxidos de La e Ce praticamente se equivalem (21,7 contra $22,5 \%)$, enquanto que nas análises acima o óxido de cério predomina largamente $(18,7$ contra $31,3 \%)$, apesar de existirem análises com distribuição mais balanceada. Além de uma indubitável variação nas composições de monazita, essa diferença também é devida ao recálculo das análises para 100\%, e provavelmente a 
alguma imprecisão maior das análises por EDS. O mesmo poderia ser também inferido em relação à comparação com as duas análises por ICP de "fosfatos secundários" de Pereira (1995), com teor de ETR total de 40,4 e 52,7\% (que devem ser monazita, a primeira impura, pelos teores de ETR), mas com La representando por volta de metade dos elementos. Na comparação com as análises de diversas ocorrências de monazita brasileiras e mundiais arroladas em Lapido Loureiro (1994), no entanto, percebe-se que as análises acima apenas diferem das de outras localidades pela ausência de Th, um dos maiores problemas ambientais da produção de terras raras e certamente um fator de desqualificação de diversas ocorrências, e uma enorme vantagem competitiva desse potencial minério.

O teor de Sr é elevado nas monazitas, média de 3,3\% do elemento, e a sua recuperação como subproduto deveria ser considerada como alternativa para agregar valor ao minério, dependendo, é claro, da viabilidade técnica e econômica. Não foram encontradas análises de Sr em monazitas, nas publicações consultadas.

Outro carreador de terras raras é a cerianita. A sua importância no minério silexítico é bem restrita, uma vez que sempre ocorre em partículas muito finas. A principal característica da cerianita, aliás, é que sempre se apresenta com secção circular, permitindo supor que é sempre esférica, e em dimensões raramente superiores a $1 \mu \mathrm{m}$, mas geralmente da ordem de $0,1 \mu \mathrm{m}$. A cerianita ocorre mais freqüentemente associada a monazita ou a minerais de $\mathrm{Fe}$, mas também pôde ser observada em quartzo. As imagens das Figuras 4.10 e 4.11 mostram a associação da cerianita com monazita e quartzo, e a da Figura 4.12 uma cerianita restrita a uma camada em particular da monazita, mais intercrescida com quartzo. 


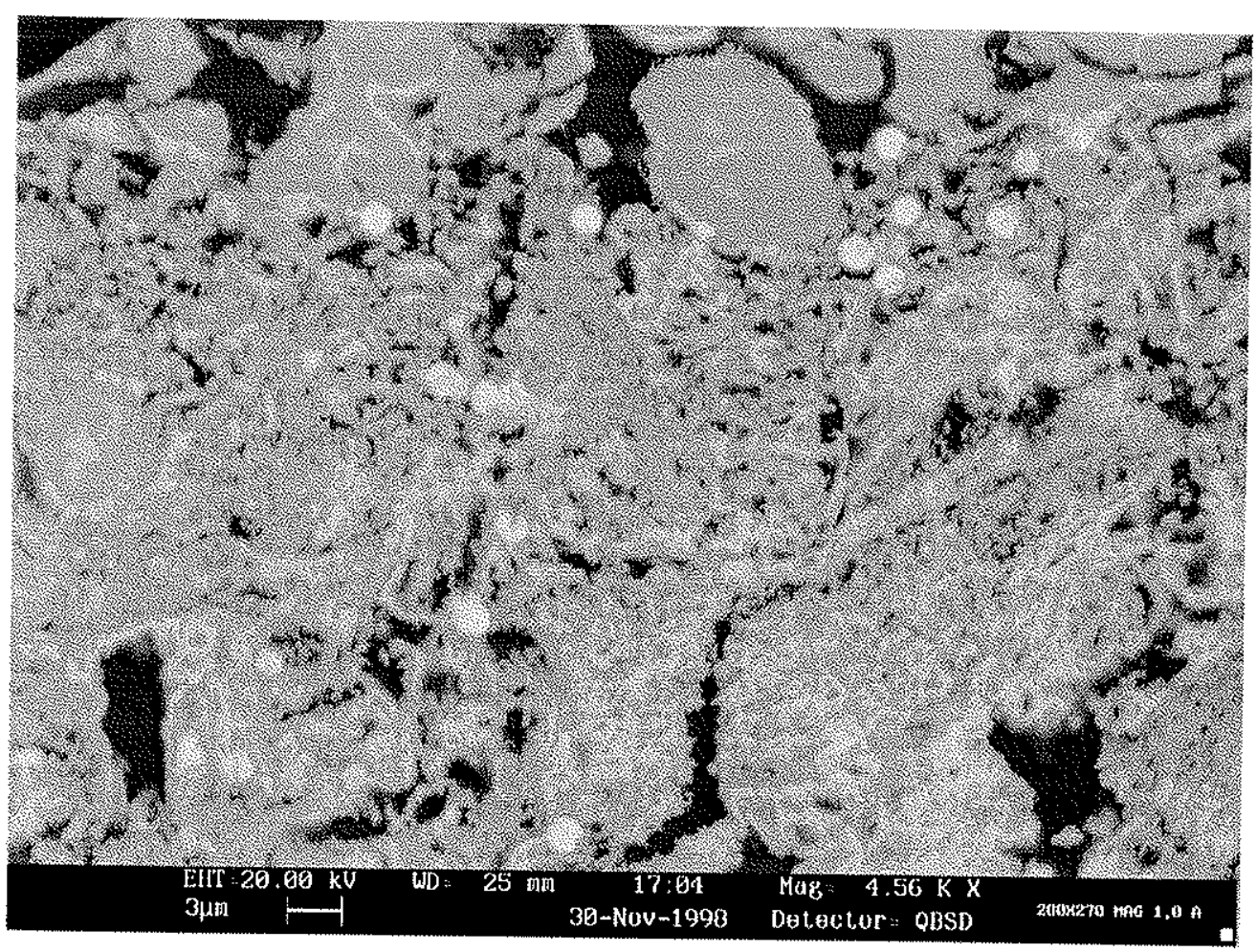

Figura 4.10 - Cerianita (círculos mas claros) dispersas em monazita (níveis de cinza intermediários) e quartzo. MEV/BSD.

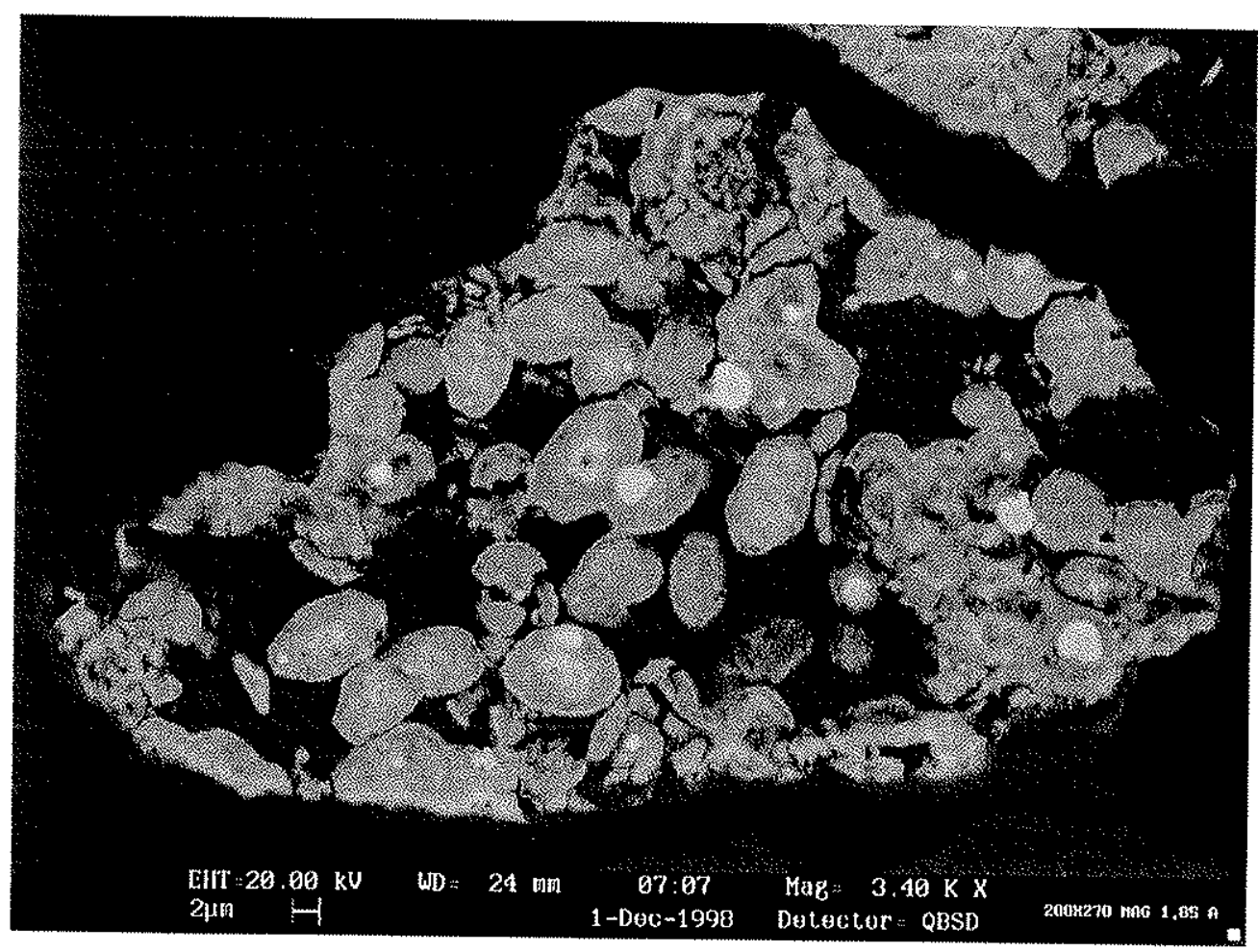

Figura 4.11 - Cerianita (circulos mais claros) associada preferencialmente à monazita (níveis de cinza intermediários), e quartzo. MEV/BSD. 


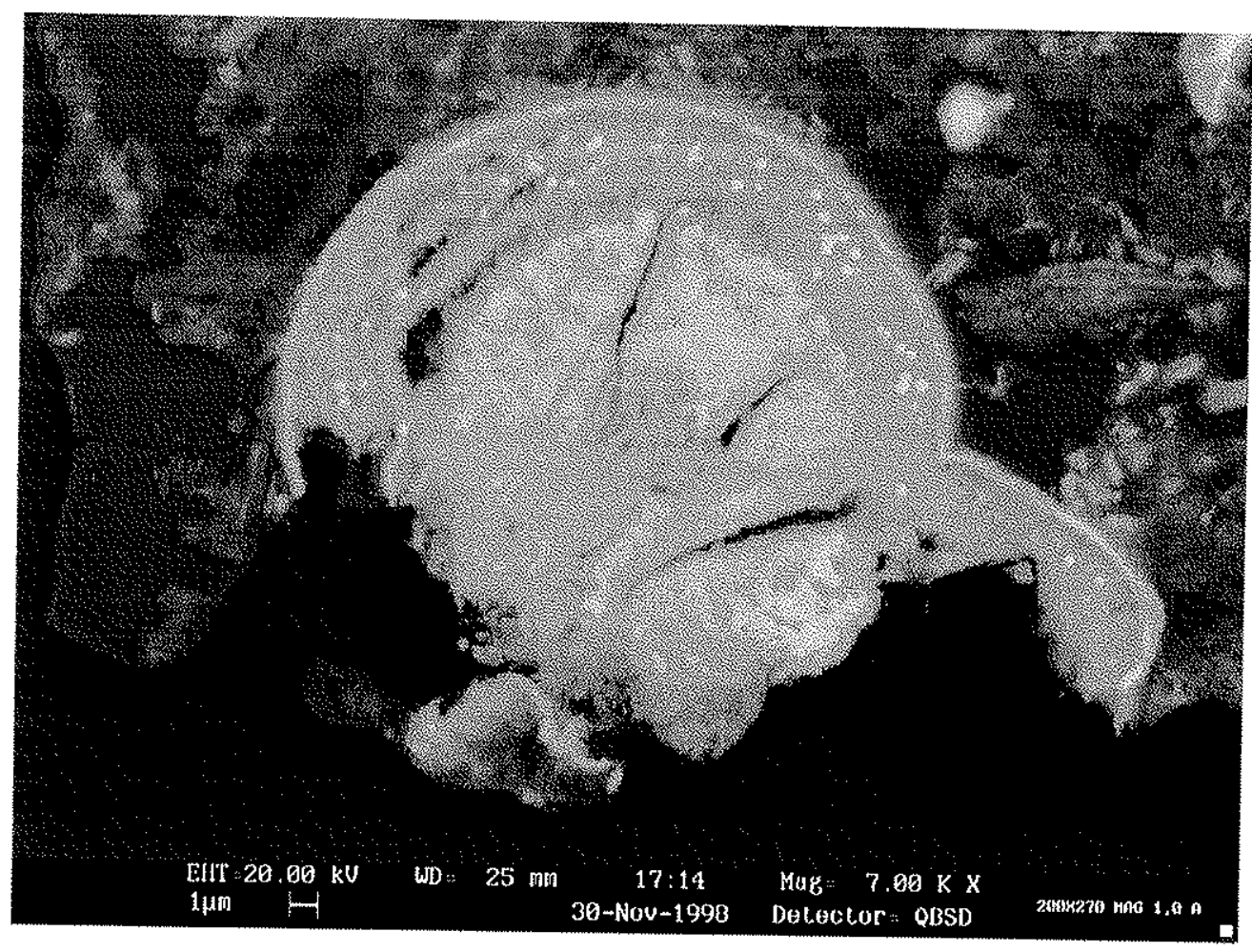

Figura 4.12 - Esferas submicrométricas de cerianita associadas preferencialmente a uma camada específica (mais escura) de monazita, mas também a minerais de Fe (centro, à direita). A partícula maior, no canto superior direito, é de barita. MEV/BSD.

As imagens das Figuras 4.13 e 4.14 mostram a associação da cerianita, submicrométrica, a óxidos/hidróxidos de $\mathrm{Fe}$, e a da Figura 4.15 a quartzo, monazita e hollandita. 


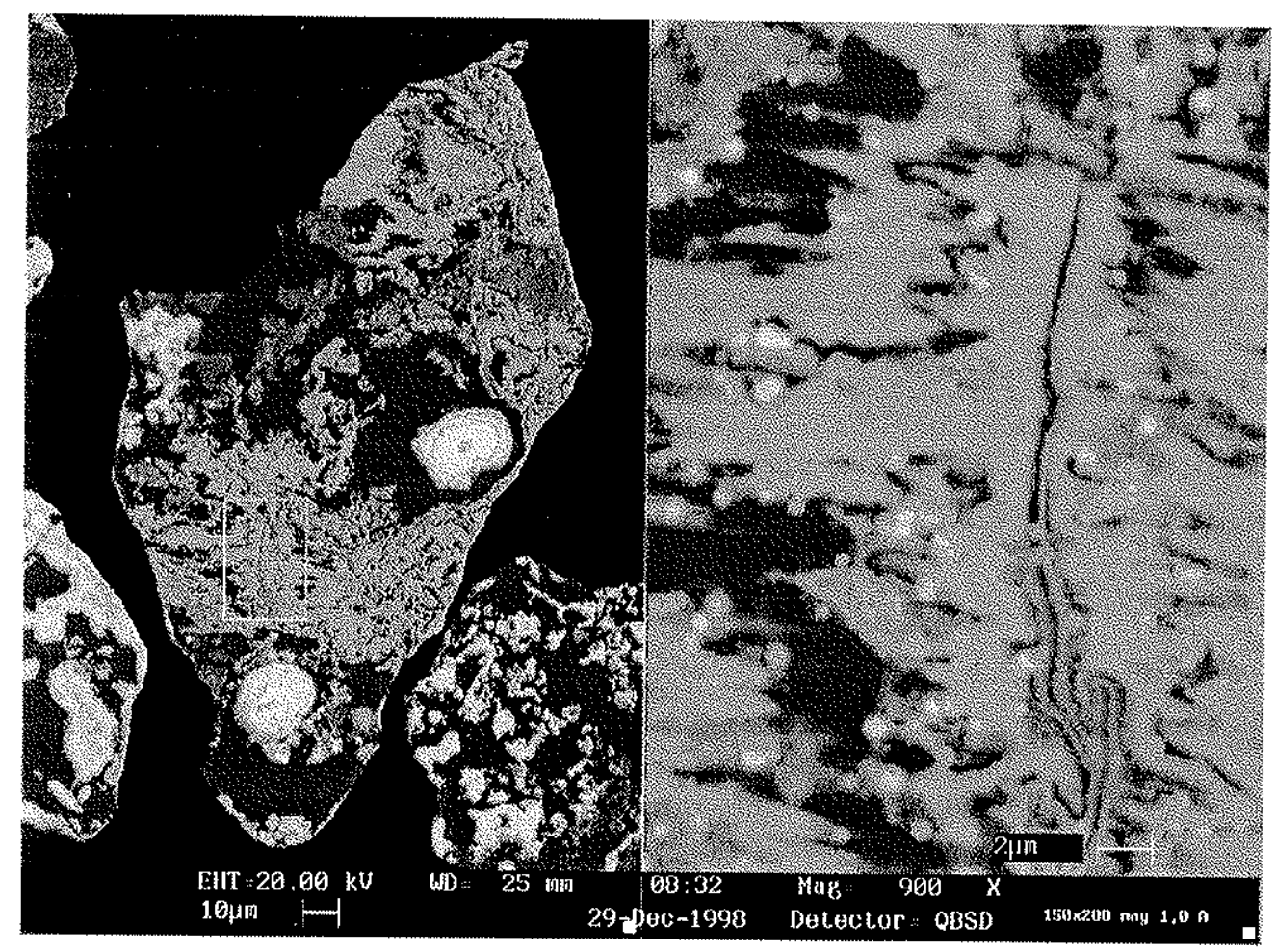

Figura 4.13 - Cerianita esférica muito fina associada e restrita a minerais de $\mathrm{Fe}$ aparentemente em dissolução, gerando estruturas do tipo "ghost", e quartzo com monazita esferoidal. MEV/BSD.

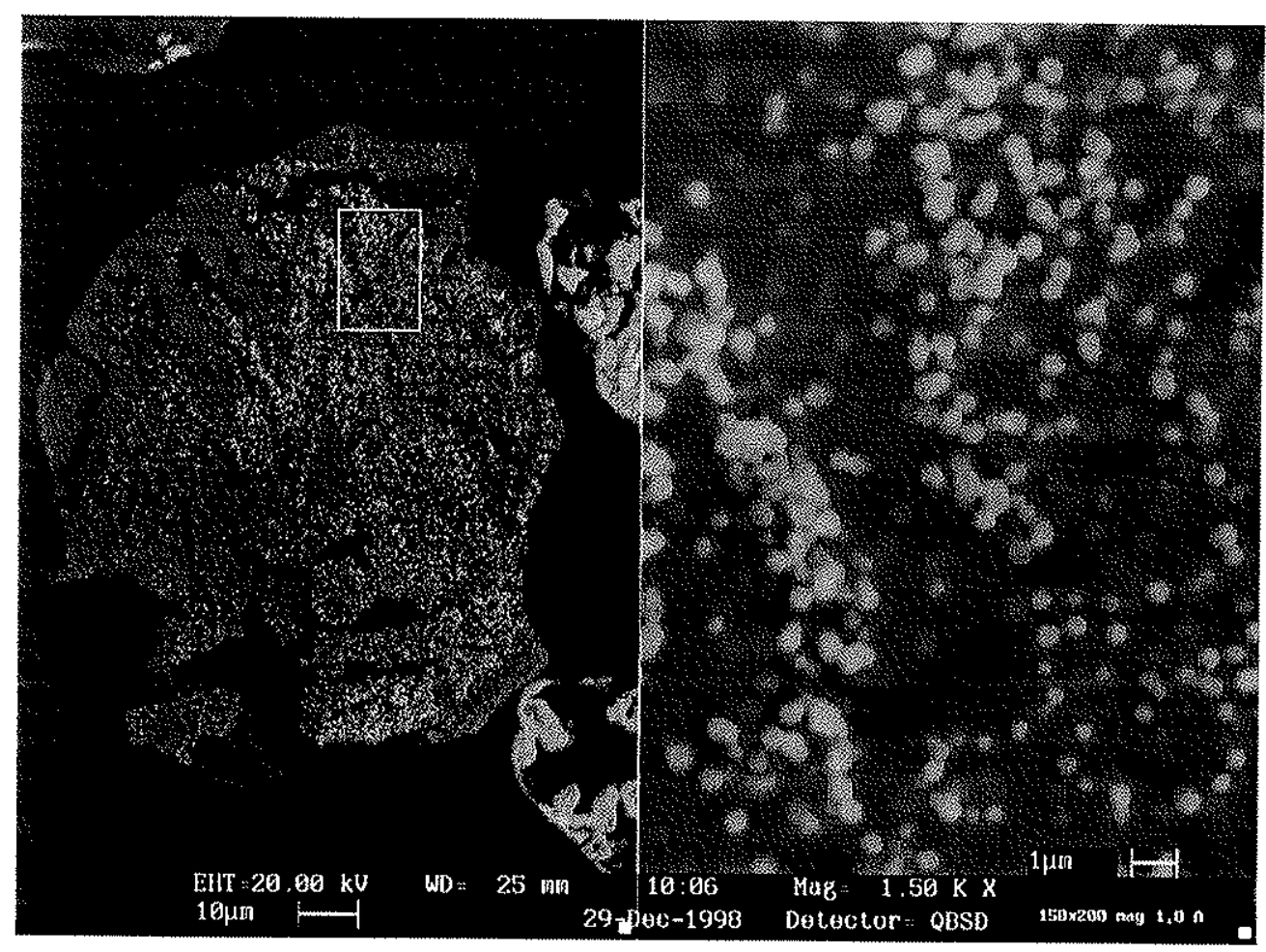

Figura 4.14 - Cerianita esférica extremamente fina associada e restrita a minerais de Fe, por sua vez intercrescidos com quartzo. MEV/BSD. 


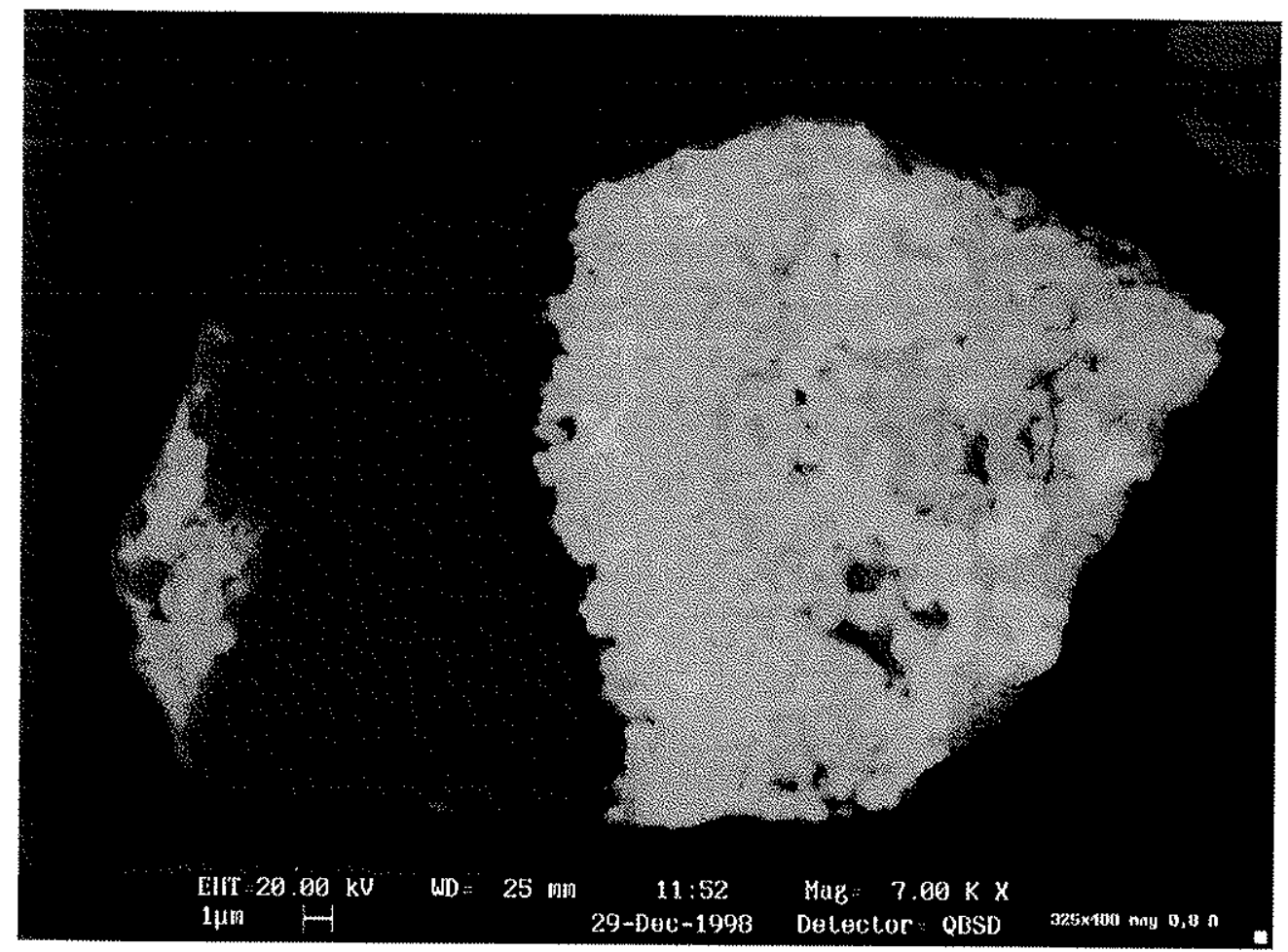

Figura 4.15 - Cerianita esférica muito fina entre quartzo (esquerda) e monazita (direita). Associada à cerianita, à sua direita, ocorre uma fase de nível de cinza intermediário entre cerianita e monazita, caracterizada como óxido de Mn e Ba. MEV/BSD.

A identificação da cerianita provém principalmente das análises de EDS, que mostram Ce como ETR que predomina largamente, e um pico de fósforo muito pequeno ou ausente. A dimensão das esferas de cerianita, no entanto, é um grande limitante na precisão da análise, ainda mais quando há uma forte associação com a monazita, que influencia as contagens de $P$ e das outras TR, além do próprio Ce. Quando associada aos minerais de $\mathrm{Fe}$, por outro lado, invariavelmente o tamanho das esferas é ainda menor, e a análise torna-se, portanto, mais imprecisa. Algumas parículas, no entanto, foram encontradas associadas exclusivamente a quartzo, pelo que pôde ser avaliado bidimensionalmente, e pôde-se obter, então, análises da cerianita pela subtração do quartzo, com resultados reproduzidos na Tabela 4.19. 
Tabela 4.19 - Análises quimicas pontuais (por EDS, \% em massa) de cerianitas de Catalão, recalculas após subtração de sílica.

\begin{tabular}{ccccccc}
\hline $\mathrm{O}$ & $\mathrm{P}$ & $\mathrm{Ca}$ & $\mathrm{Sr}$ & $\mathrm{La}$ & $\mathrm{Ce}$ & $\mathrm{Nd}$ \\
\hline 25,7 & 4,2 & 2,0 & 0,3 & 0,0 & 67,8 & 0,0 \\
25,0 & 8,0 & 2,2 & 1,6 & 6,4 & 55,7 & 1,1 \\
28,5 & 10,7 & 2,4 & 2,2 & 8,7 & 44,1 & 3,4 \\
27,6 & 10,4 & 2,2 & 2,5 & 8,7 & 45,5 & 3,0 \\
27,7 & 8,9 & 2,2 & 1,8 & 5,3 & 52,6 & 1,5 \\
\hline
\end{tabular}

Pode-se observar claramente nessas análises que provavelmente há monazita presente na cerianita, e que o teor de $\mathrm{Ca}, \mathrm{Sr}$, La e $\mathrm{Nd}$ acompanha o de $\mathrm{P}$, ou seja, esses elementos provavelmente estão no retículo de monazita, e não da cerianita. $A$ presença dessa cerianita, no entanto, ainda não pôde ser definitivamente provada, uma vez que os espectros de raios $X$ sugerem a sua presença, mas os seus picos mais imporłantes são próximos a picos de monazita e fluorapatita, e a quantidade é muito pequena para que os seus picos menores se destaquem do background.

Três minerais de ferro foram identificados por difração de raios $X$, magnetita, hematita e goethita, e mais uma mistura de óxidos/hidróxidos amorfos ou muito mal cristalizados, sempre contendo Si elevado nos espectros de EDS, chamada classicamente de limonita. Essas fases não podem ser identificadas a contento ao MEV/EDS, uma vez que o hidrogênio não é detectado. Quando uma fases anidra (magnetita e hematita) aparece na mesma imagem que uma fase hidratada (goethita $e$ limonita), é possivel inferir a presença de ambas, pela diferença no nível de cinza, mais escuro nas hidratadas pela presença do leve hidrogênio. Quando ocorre um pico expressivo de Si, da mesma forma, é possível inferir que se trata de limonita, mas sempre com muitas reservas, uma vez que silicio é extremamente comum e finamente disseminado nesse minério.

O modo de ocorrência mais comum de minerais de $\mathrm{Fe}$ é finamente disseminados no quartzo, numa trama muito fina que lembra bastante o mesmo intercrescimento também observado do quartzo com a monazita. A imagem da Figura 4.16 mostra uma vista geral, e a associação muito íntima de quartzo e minerais de $\mathrm{Fe}$ (e alguma monazita). O detalhe da Figura 4.17 mostra methor o intercrescimento a nível nanométrico entre ambos. 


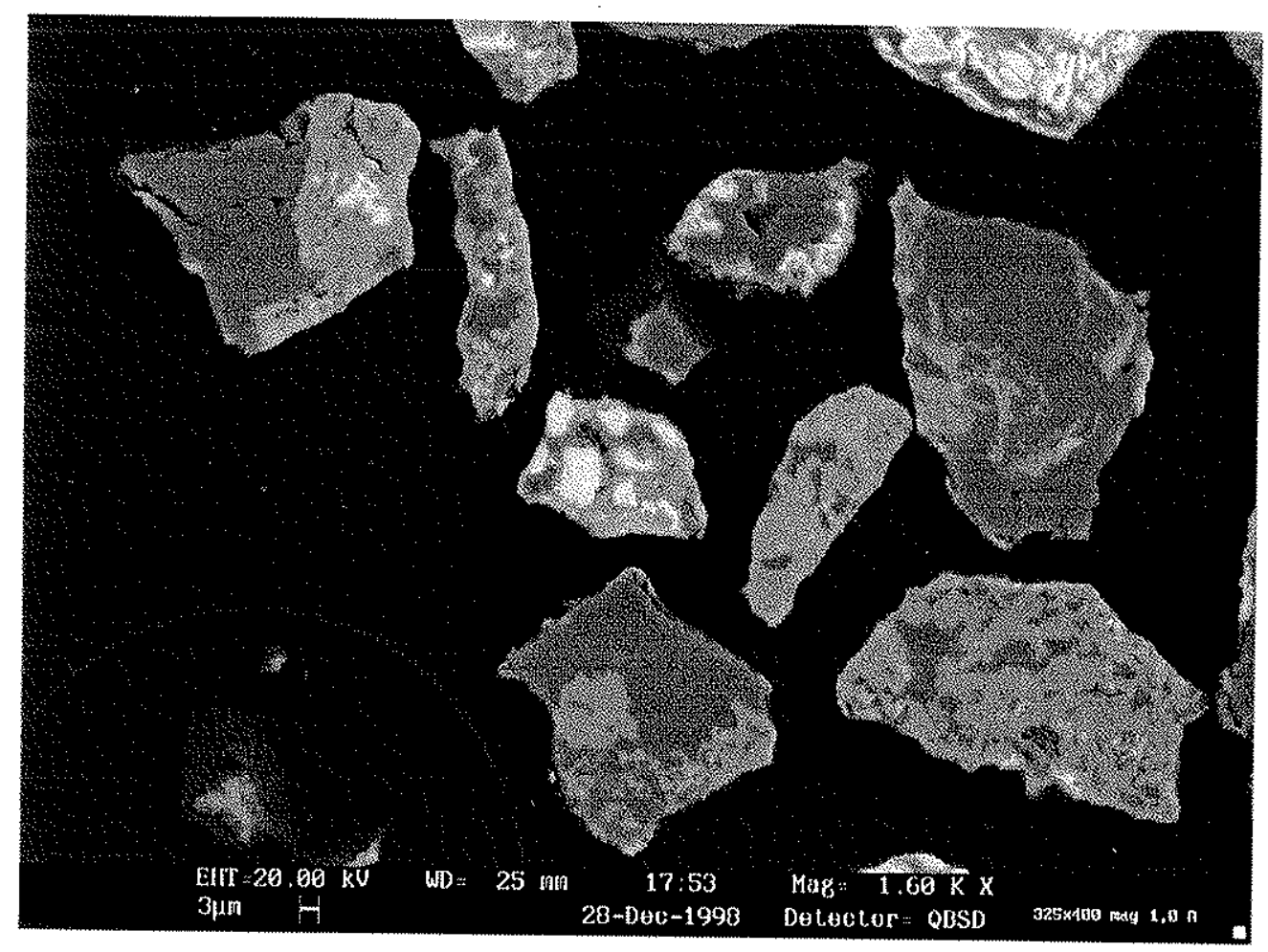

Figura 4.16 - Vista geral mostrando quartzo intercrescido com minerais de $\mathrm{Fe}$, em diferentes proporções, além de monazita. MEV/BSD.

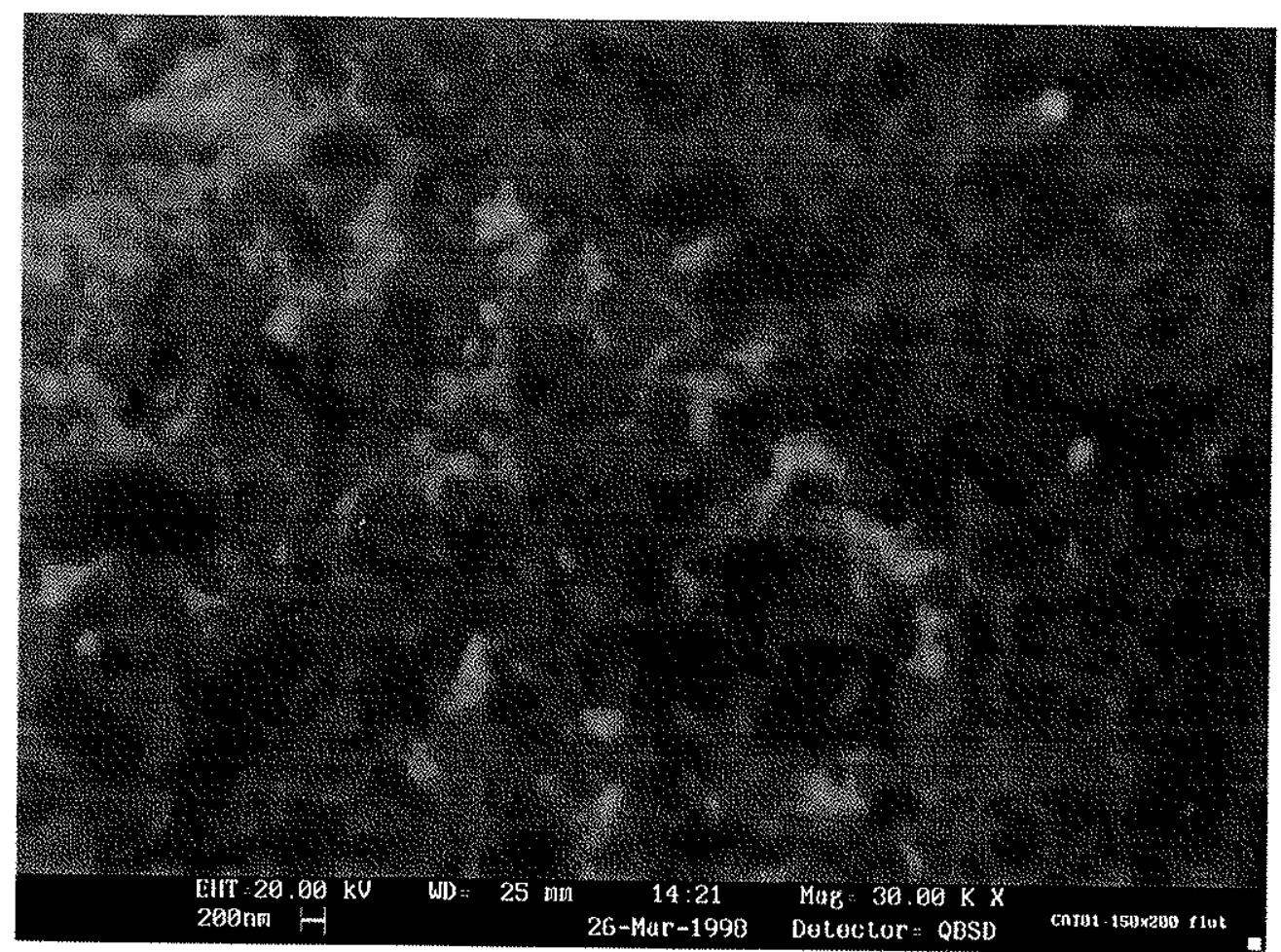

Figura 4.17 - Intercrescimento muito fino entre fase de Fe e quartzo. MEV/BSD. 
O contraste de níveis de cinza que permite inferir minerais de Fe hidratados e não hidratados está exemplificado na Figura 4.18. O detalhe da imagem também mostra a tendência da fase hidratada a formar agulhas. Essa mesma tendência também pode ser observada na fase ferruginosa na imagem da Figura 4.6 (embora não esteja claro se é hidratada ou não), substituindo pseudomorficamente um cristal hexagonal (possivelmente de apatita), e na Figura 4.19, abaixo.

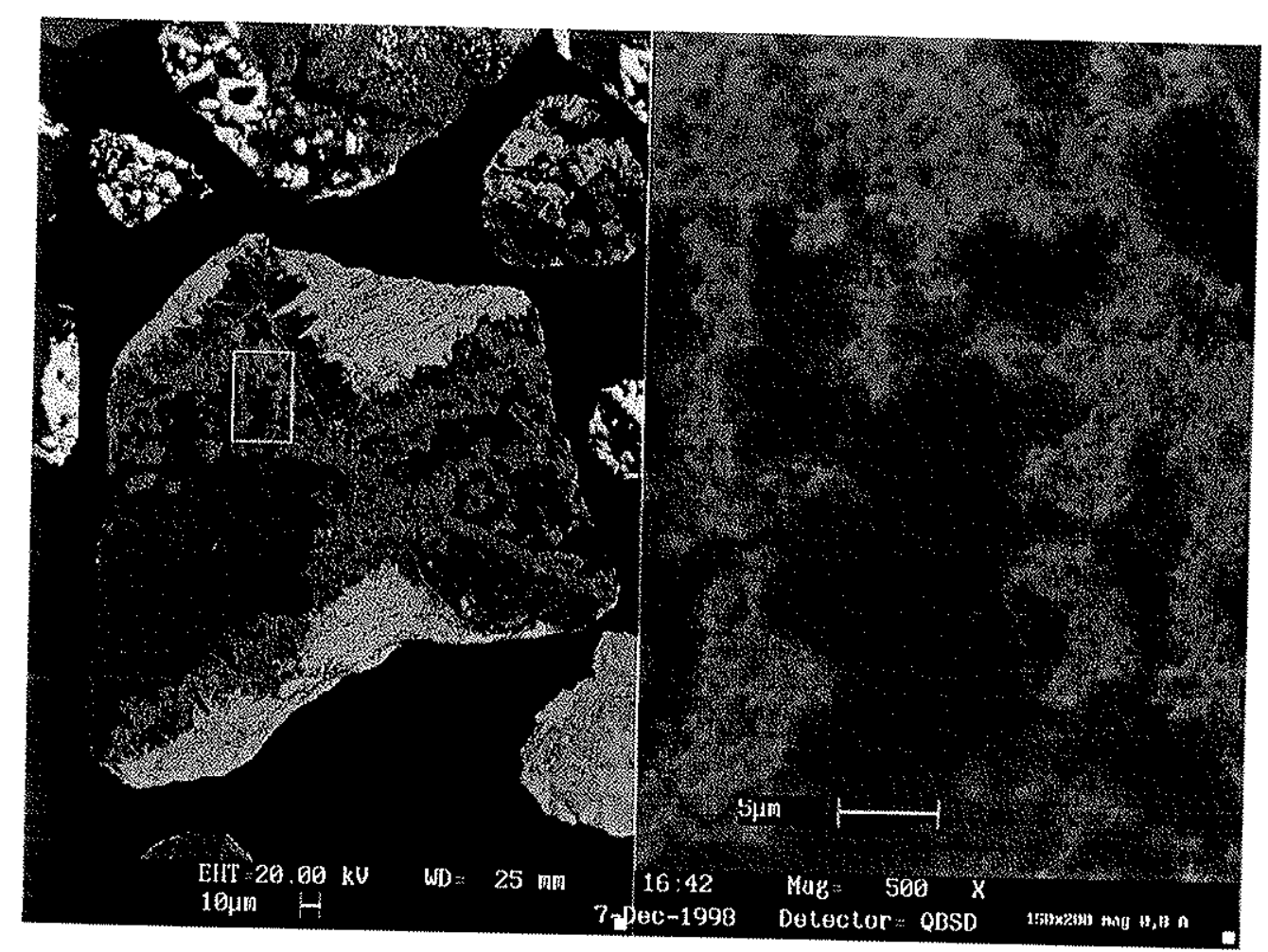

Figura 4.18 - Dois minerais de Fe distintos, óxido de Fe (hematita ou magnetita - mais claro) e óxido hidratado de Fe (goethita ou limonita - cinza médio), distinguíveis pelo seu nivel de cinza, intercrescidos com quartzo. O detalhe mostra o caráter acicular da fase provavelmente hidratada. MEV/BSD 


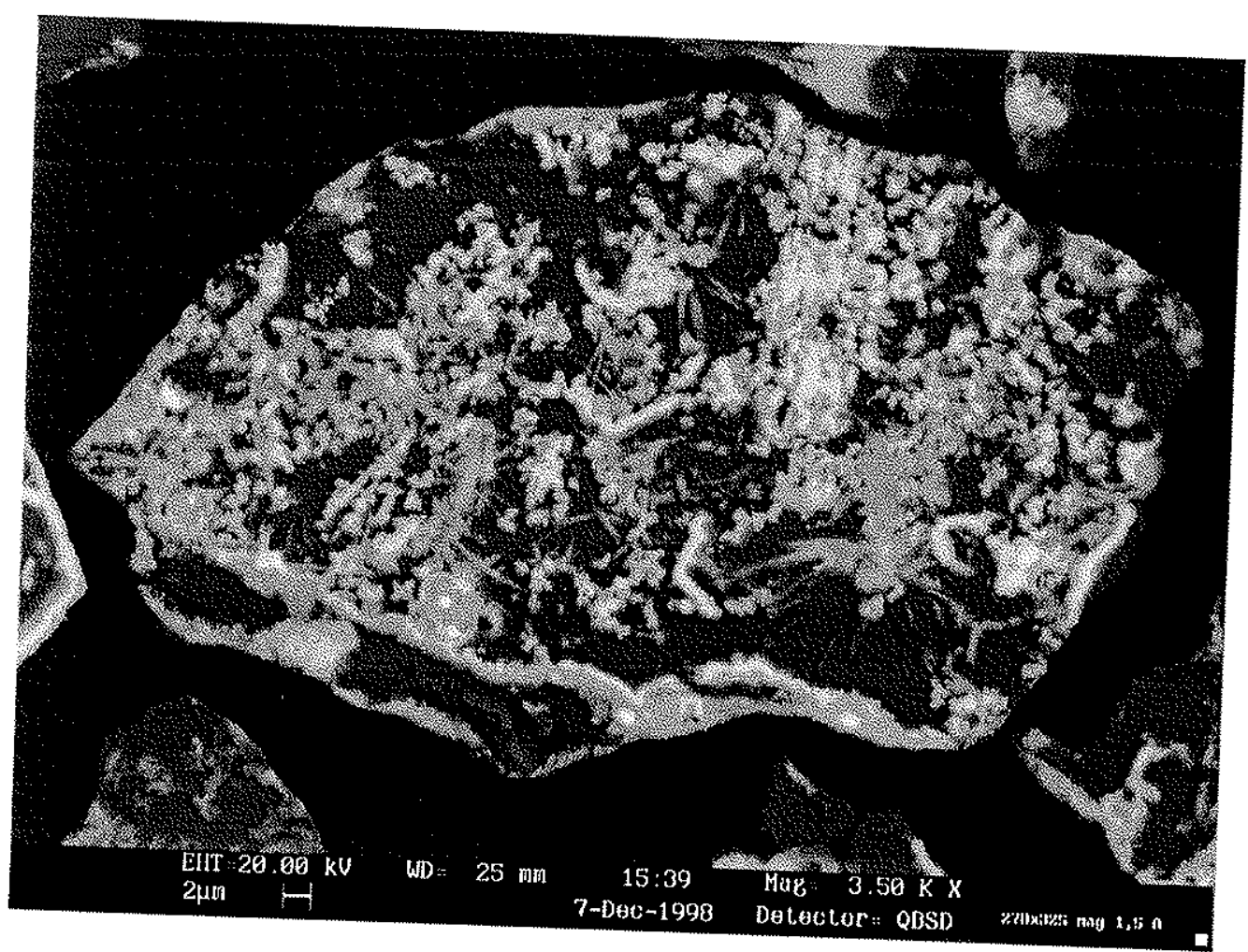

Figura 4.19 - Óxido/hidróxido de ferro acicular e monazita em quartzo. MEV/BSD.

Outros minerais observados foram barita, fluorapatita e hollandita, sempre em pequenas quantidades. Barita e fluorapatita são identificáveis também por difração de raios X. Um óxido de Mn e Ba foi identificado por MEV/EDS, e a difração não é conclusiva, uma vez que a quantidade é muito reduzida. As análises por DRX, no entanto, são muito mais indicativas de uma hollandita do que de outras fases contendo os mesmos elementos, como romanechita (uma vez que picos importantes deses minerais não puderam ser observados em regiões sem picos de outras fases), e portanto optou-se por, tentativamente, considerar que esse seja o mineral. Raros grãos de pirocloro (com $\mathrm{Pb}, \mathrm{TR}, \mathrm{Ti}$ e $\mathrm{Fe}$ ) e de mica, provável flogopita, também foram observados. Nas frações magnéticas ao imã de mão, puderam ser visualizados muitos fragmentos de Fe metálico contornados por capa de oxidação, certamente devidos ao intenso desgaste que esse minério, muito duro, provocou em britadores e moinhos durante a preparação da amostra. Vale registrar aqui que a britagem primária do minério silexítico foi responsável pela destruição parcial de um britador de mandíbulas. 


\section{Análise de Imagens}

A Tabela 4.20 apresenta o teor de ponto, linha e área de monazita do minério silexitico, como obtido pela análise das imagens. Apresenta também o teor de cabeça composto, em volume e massa, considerando as frações analisadas (de 105 a $20 \mu \mathrm{m}$ ) fechando em $100 \%$, ou seja, desprezando os finos, e uma estimativa de composição química da cabeça composta, considerando-se a composição estequiométrica da monazita (1 de monazita $=0,6 \mathrm{TR}_{2} \mathrm{O}_{3}$ ), agora incluindo os finos no balanço, com o teor de $13,30 \%$ de $\mathrm{TR}_{2} \mathrm{O}_{3}$, obtido por análise química. Para cálculo de volume para massa foram utilizadas as densidades 5,20 para monazita e 2,70 para a ganga. Esses cálculos servem basicamente para verificar se os procedimentos de análise de imagem introduziram algum erro grotesco, como segmentação errada ou eliminação de partes importantes da monazita, que teria como conseqüência um teor de monazita muito diferente do verificado pela análise química.

Tabela 4.20 - Teores de monazita de ponto, linha e área, medidos por análise de imagens, cabeça composta de monazita desconsiderando a fração fina, - $20 \mu \mathrm{m}$, e teor de $\mathrm{TR}_{2} \mathrm{O}_{3}$ de cabeça calculado a partir da monazita e da análise química da fração fina,
$-20 \mu \mathrm{m}$.

\begin{tabular}{lccc|ccc}
\hline & \multicolumn{3}{c|}{ Volume $(\%)$} & \multicolumn{3}{c}{ Massa (\%) } \\
\hline Fraçäo $(\mu \mathrm{m})$ & Pixel & Linear & Área & Pixel & Linear & Área \\
\hline $105 \times 74$ & 8,81 & 9,06 & 8,91 & 15,69 & 16,10 & 15,85 \\
$74 \times 53$ & 9,91 & 9,88 & 9,74 & 17,48 & 17,43 & 17,21 \\
$53 \times 44$ & 8,96 & 9,00 & 8,91 & 15,93 & 16,00 & 15,85 \\
$44 \times 37$ & 8,18 & 8,20 & 8,12 & 14,64 & 14,68 & 14,54 \\
$37 \times 20$ & 7,73 & 7,78 & 7,81 & 13,89 & 13,98 & 14,03 \\
\hline Composto & 8,77 & 8,87 & 8,77 & 15,61 & 15,77 & 15,62 \\
\hline TR $_{2} \mathrm{O}_{3}$ calculado + finos AQ & & 10,46 & 10,53 & 10,47 \\
\hline
\end{tabular}

Observa-se que há uma coerência muito boa entre os resultados de teores de ponto, linha e área em todas as medidas; teoricamente iguais, os valores tendem a diferir um pouco pois a metodologia de mediçâo de cada um é diferente. Além disso, o teor de $\mathrm{TR}_{2} \mathrm{O}_{3}$ calculado a partir da análise de imagens, e com balanço metalúrgico fechado com a análise química dos finos, é muito próximo ao teor de cabeça desse minério obtido por análises químicas convencionais, de 10,05\% (duplicata em 10,24\%). Essa concordância muito boa não valida a análise de imagem para determinação do 
grau de liberação, mas certamente é um forte indicativo de que a segmentação e todo o processamento das imagens até as medições não alteraram substancialmente as suas características.

A liberação linear aparente, obtida pela análise de imagens das 5 frações granulométricas do minério silexítico, está representada graficamente na Figura 4.20. Pela análise desse gráfico observa-se que a maior parte dos interceptos é de ganga, apenas, em todas as classes de tamanho de partícula. Pela observação do diagrama de liberação em área aparente da Figura 4.21, no entanto, pode ser observado que parte preponderante das partículas é mista, principalmente com até $10 \%$ (vol) de monazita, mas com uma distribuição uniformemente decrescente de aproximadamente $11 \%$ das partículas que contêm de 10 a $20 \%$ de monazita até ganga sem monazita, em todas as classes de tamanho.

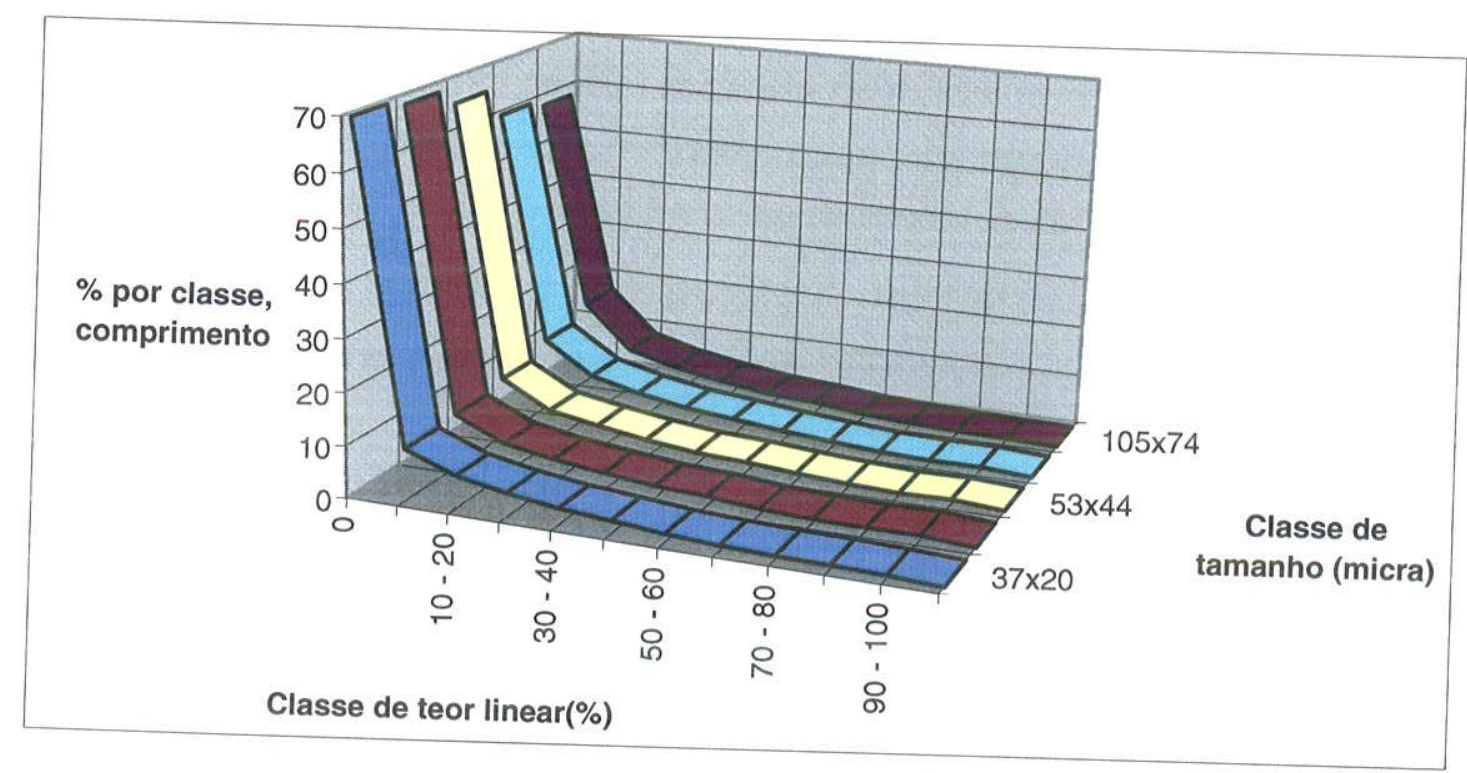
Figura 4.20 - Liberação linear aparente do minério silexítico, obtida pela análise de
imagens. Condicional por tamanho. 


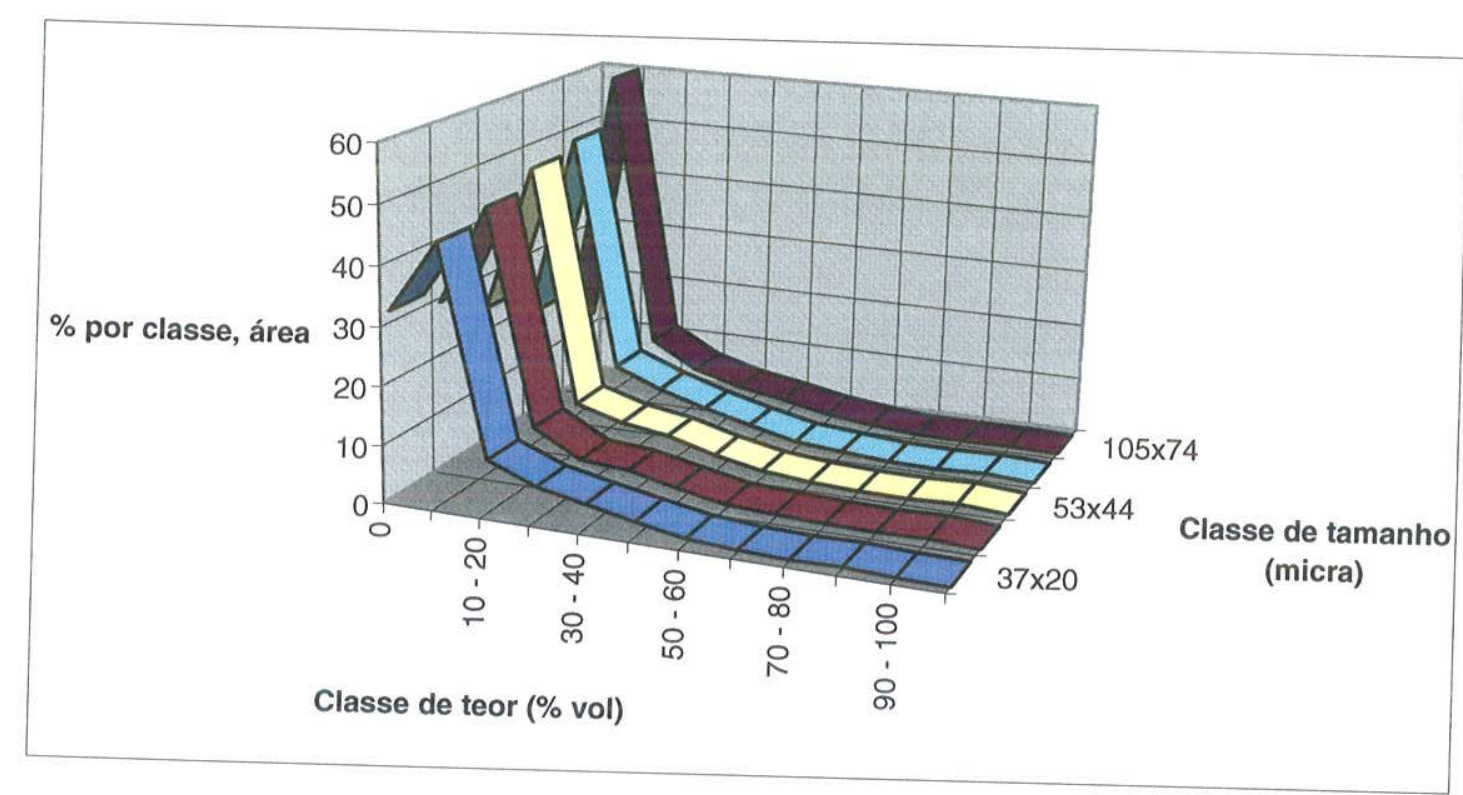
Figura 4.21- Liberação em área aparente do minério silexítico, obtida pela análise de
imagens. Condicional por tamanho.

A inversão estereológica foi processada a partir dos dados de liberação linear aparente, e não da liberação em área. Apesar das equações para inversão a partir dos dados em área serem facilmente deriváveis, há diversas razões para trabalhar com os dados lineares (King \& Schneider 1993): i) a medida de interceptos lineares pelo analisador de imagens é mais fácil, rápida, acurada e menos ambígua; ii) há uma base teórica mais sólida relacionando distribuição de interceptos lineares e textura mineral; iii) as distribuições de interceptos lineares em minérios não-quebrados são bem definidas e facilmente mensuráveis. O conceito de distribuição de área não é bem definido para a maioria das texturas minerais; iv) análise de área pode ser seriamente afetada por partículas que se tocam, mesmo que seja por um pixel apenas, uma vez que, apesar das boas rotinas de separação existentes, nenhuma é infalível em análise automatizada de imagens; v) as correções de moldura podem ser muito bem implementadas para interceptos lineares, mas não para áreas.

A análise das L-curves de Hansen plotadas com os dados do minério silexítico mostra que as frações mais grossas $(105 \times 74$ e $74 \times 53 \mu \mathrm{m})$ têm resultado melhor quando a inversão estereológica é processada com função de transformação Pargen com densidade de dispersão 10, enquanto as restantes apresentam melhor resultado com a função desenvolvida para dolomita/esfalerita alta resolução. Isso significa que a textura do minério muda com a escala observada, o que é esperado, uma vez que as 
texturas não são fractais. A Figura 4.22 exemplifica a seleção da função de transformação pelos diagramas de Hansen, no caso para a fração mais fina analisada, 20 a $37 \mu m(400 \times 635$ malhas $)$.

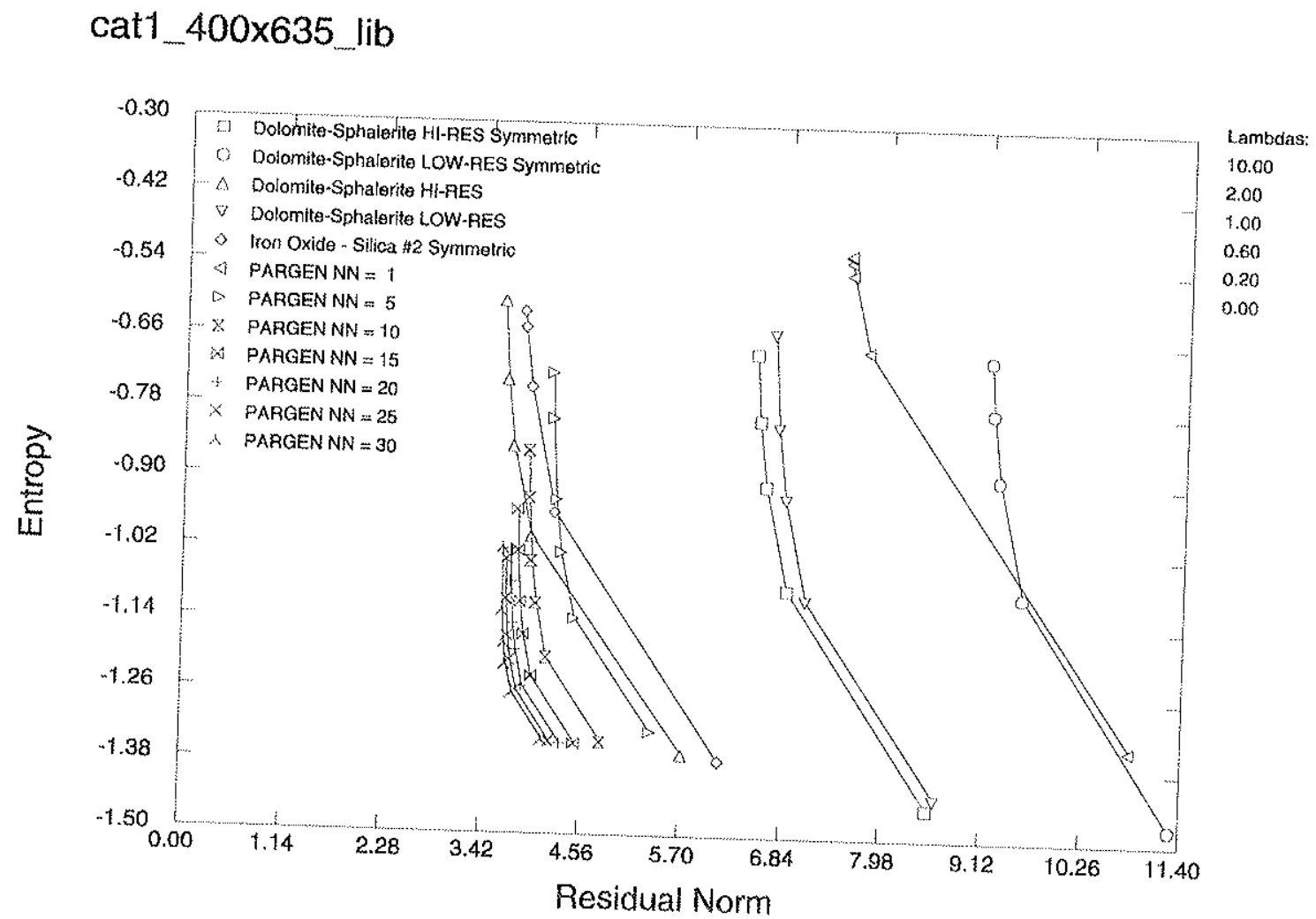

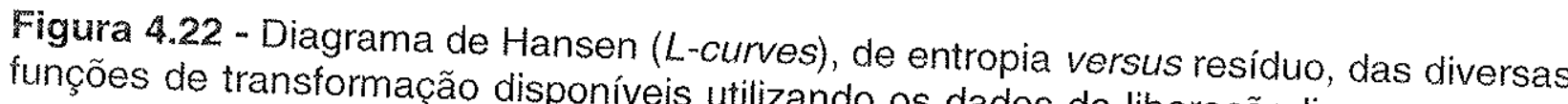
obtidos para a fração $37 \times 20 \mu \mathrm{m}$ do minério silexítico dados de liberação linear aparente selecionada dolomita-esfalerita de minério silexítico. Pode ser observado que a função entropia e resíduo.

A partir das funções de transformação selecionadas, os dados de liberação linear aparente puderam ser invertidos para liberação em volume, representada pelo
diagrama da Figura 4.23 . 


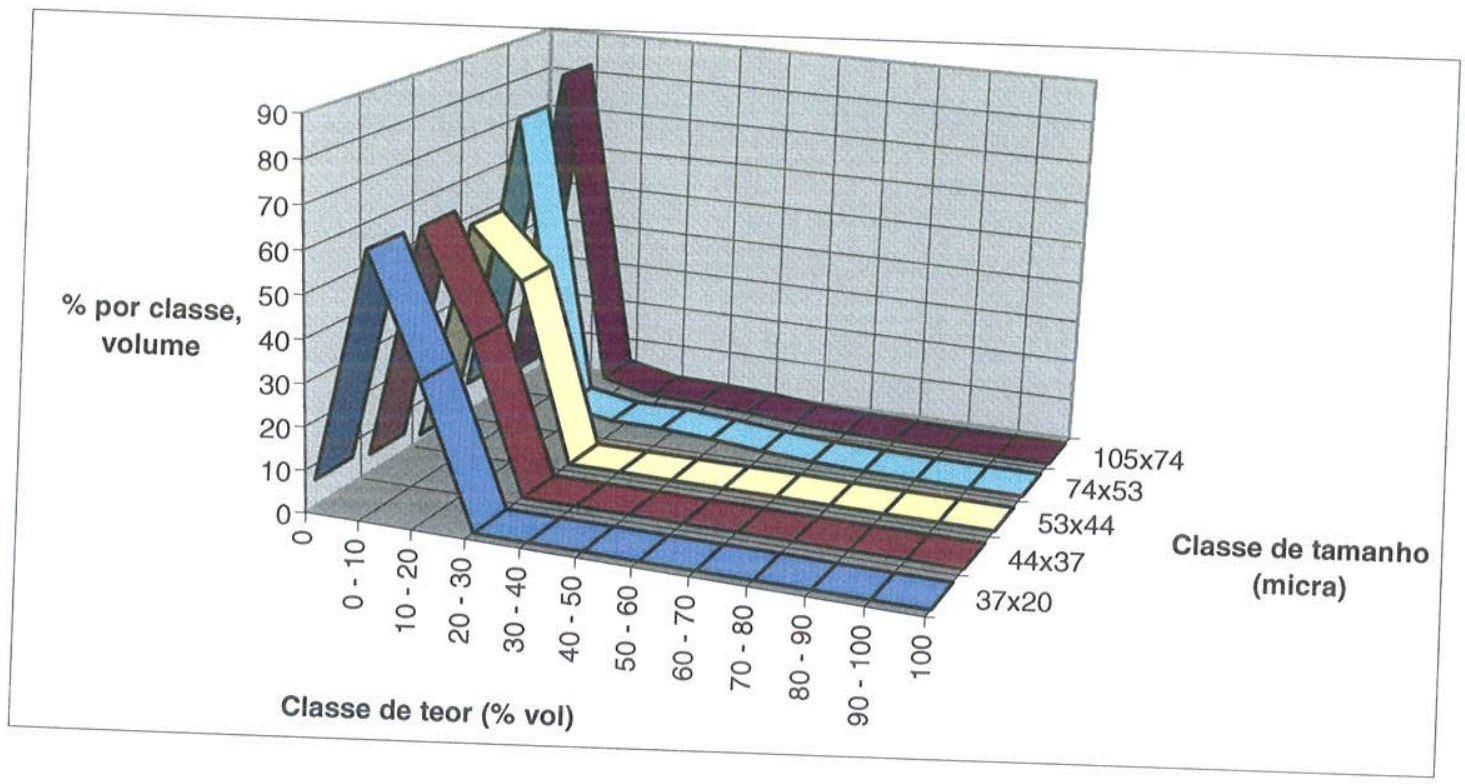

Figura 4.23 - Liberação em volume do minério silexítico, obtida pela análise de imagens, após correção estereológica. Condicional por tamanho.

Finalmente, o diagrama da Figura 4.24 apresenta os mesmos dados recalculados para massa, a partir das densidades presumidas para monazita $(5,20)$ e ganga $(2,70)$.

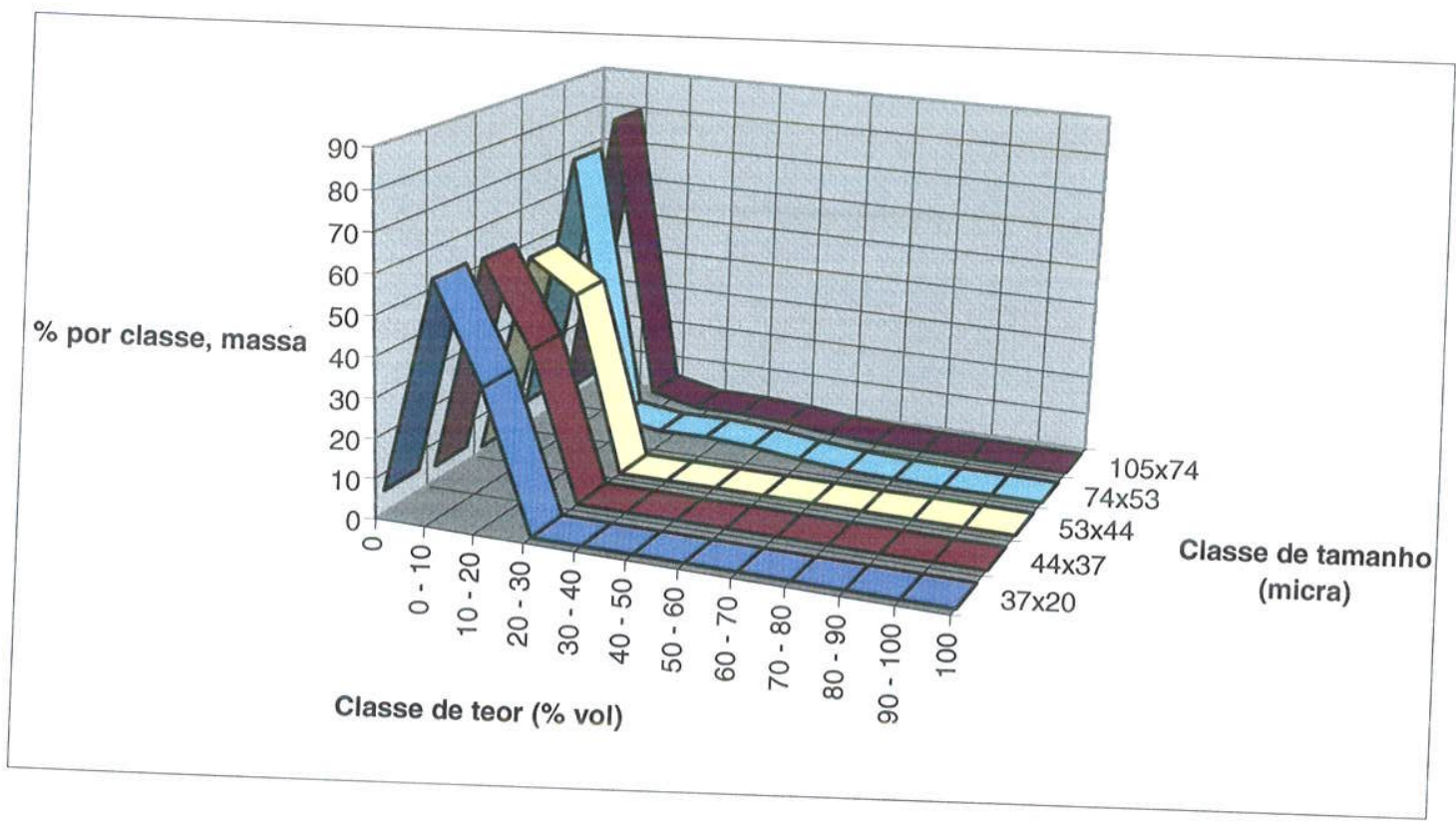
Figura 4.24 - Liberação em massa do minério silexítico, obtida pela análise de
imagens, após correção estereológica. Condicional por tamanho.

A análise dos diagramas de espectro de liberação em volume e massa, após correção estereológica, aponta para algumas propriedades muito interessantes do 
minério silexítico. A mais importante é a péssima liberação da monazita em relação à sua ganga. Nenhuma das classes de tamanho/teor com mais de $20 \%$ em volume de monazita contém mais de $10 \%$ das particulas em sua faixa granulométrica, independente dessa. A segunda caracteristica é a má liberação da ganga em relação à monazita: apesar de a quase totalidade das partículas conter entre 0 e $20 \%$ de monazita, e não mais, bem menos de 10\% contêm exclusivamente ganga. Essa feição já havia sido detectada na liberação aparente em área, e foi corretamente re.introduzida pela correção estereológica, uma vez que entre 58 e $70 \%$ (dependendo da granulometria) dos interceptos lineares são apenas de ganga. Além dos dados de liberação aparente em área, uma atenta observação ao MEV das partículas onde predomina ganga reaimente confirma a presença quase constante de pequenas quantidades de monazita, geralmente na superfície das partículas, como pode ser observado nas imagens das Figuras 4.25 e 4.26. Na imagem da Figura 4.25 observase uma camada mais substancial de monazita, de aproximadamente $2 \mu \mathrm{m}$, inclusive com hábito esferoidal reconhecivel em alguns lugares. Geralmente a camada é mais fina. A imagem da Figura 4.26 é uma das que foram utilizadas para análise de imagens, escolhida aleatoriamente, e novamente pode-se observar monazita superficial em quase todas as partículas onde predomina ganga.

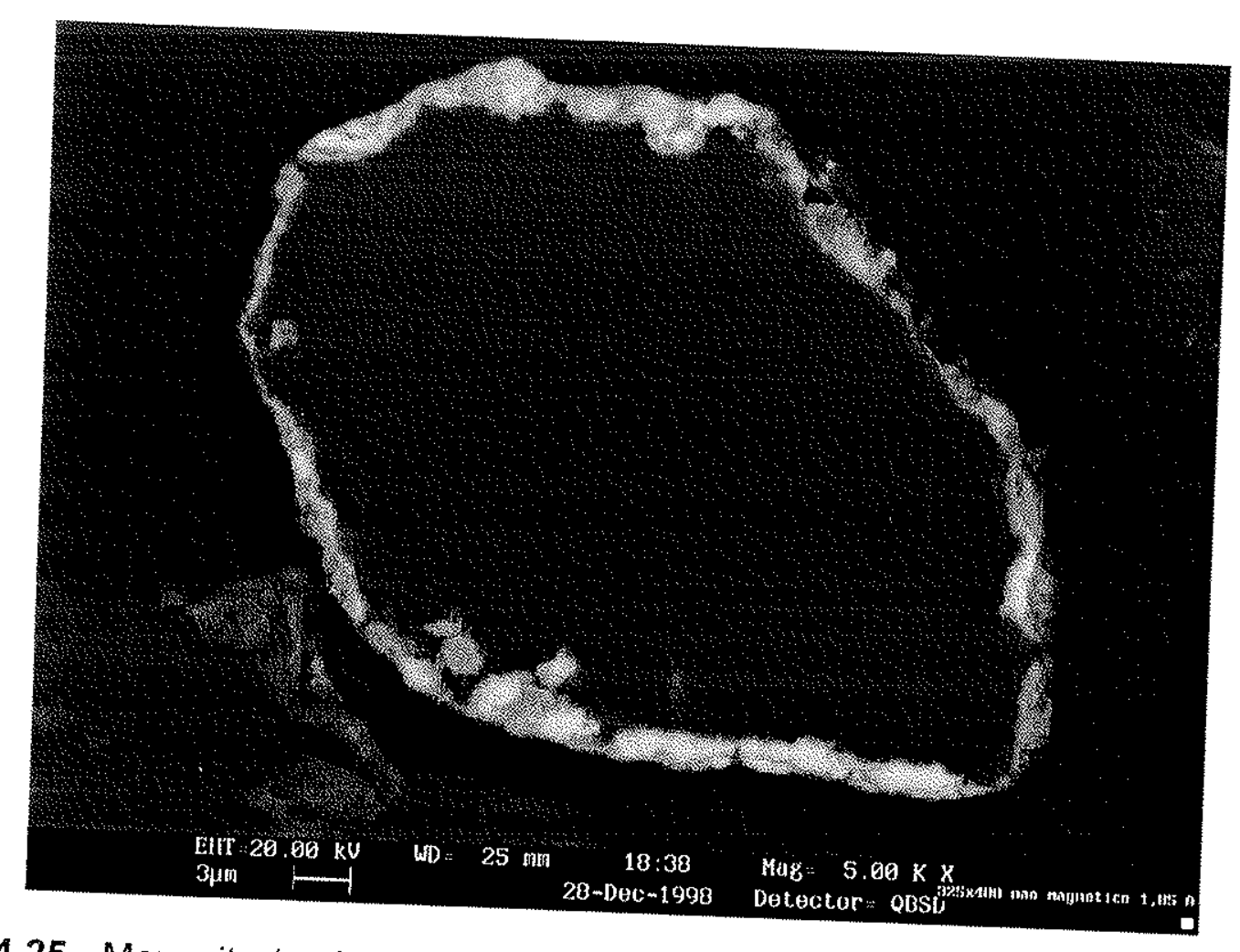

Figura 4.25 - Monazita (mais clara) na borda de grão de quartzo (MEV/BSD). 


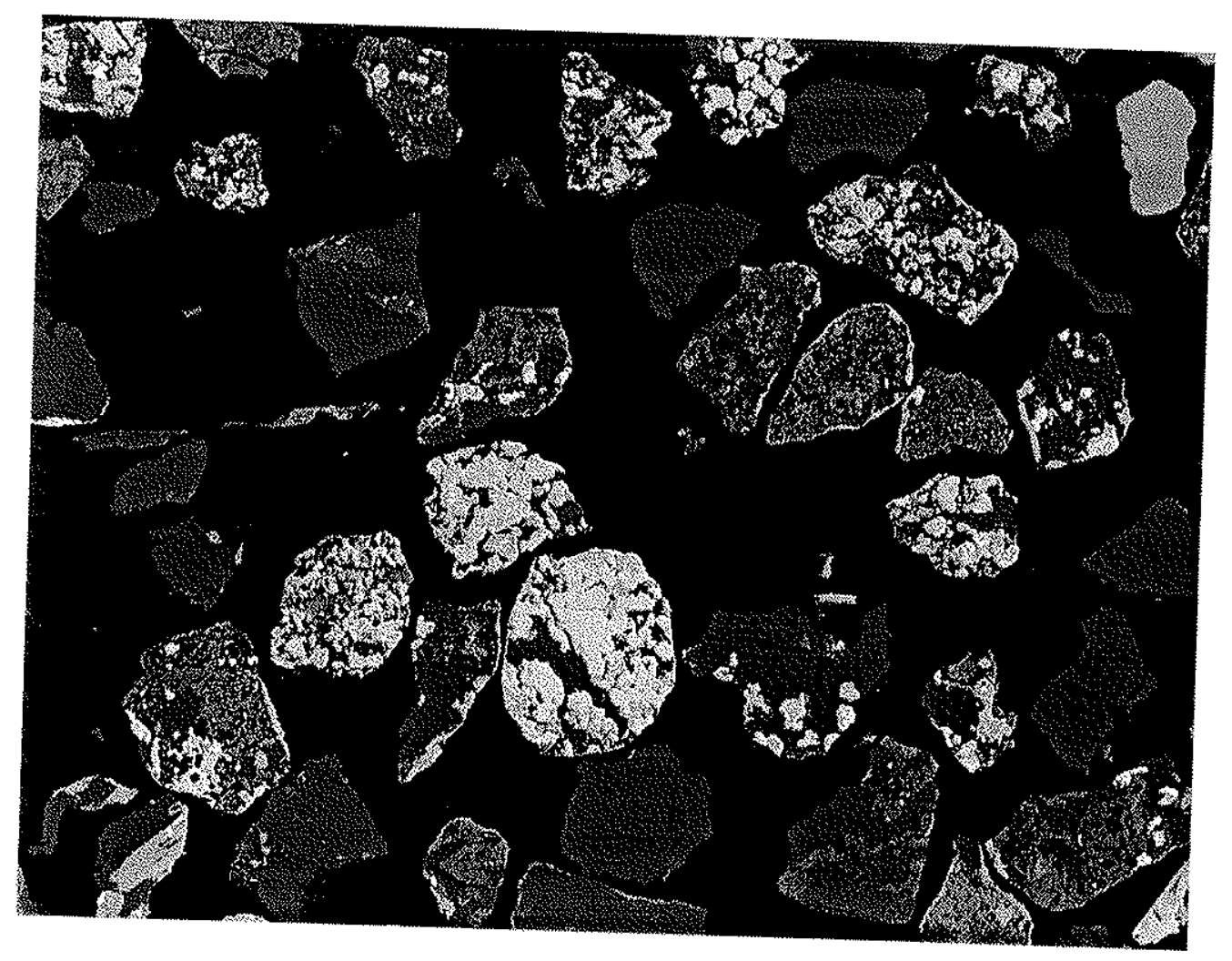

Figura 4.26 - Imagem utilizada para a análise de imagens (MEV/BSD), com quartzo (cinza escuro), monazita (cinza mais claro) e minerais de $\mathrm{Fe}$ (cinza intermediário). partículas, inclusive naquelas desena de delgados níveis de monazita na superfície das ganga.

O diagrama que representa a distribuição bivariada de tamanho e teor no minério silexítico está na Figura 4.27. Representa graficamente quanto da amostra total, em massa, tem determinado teor de monazita (em \% volume) e tamanho de partícula, e refere-se às condições de preparação dessa amostra, principalmente no que tange à cominuição (100\% abaixo de $105 \mu \mathrm{m}$, evitando a formação de finos). Usualmente, em estudos de caracterização tecnológica, seria apresentado o espectro de liberação natural do minério, mas o silexito é muito compacto e não apresenta liberação natural. A liberação em massa da fração fina foi assumida como sendo igual à da fração mais próxima a ela, $37 \times 20 \mu \mathrm{m}$. 


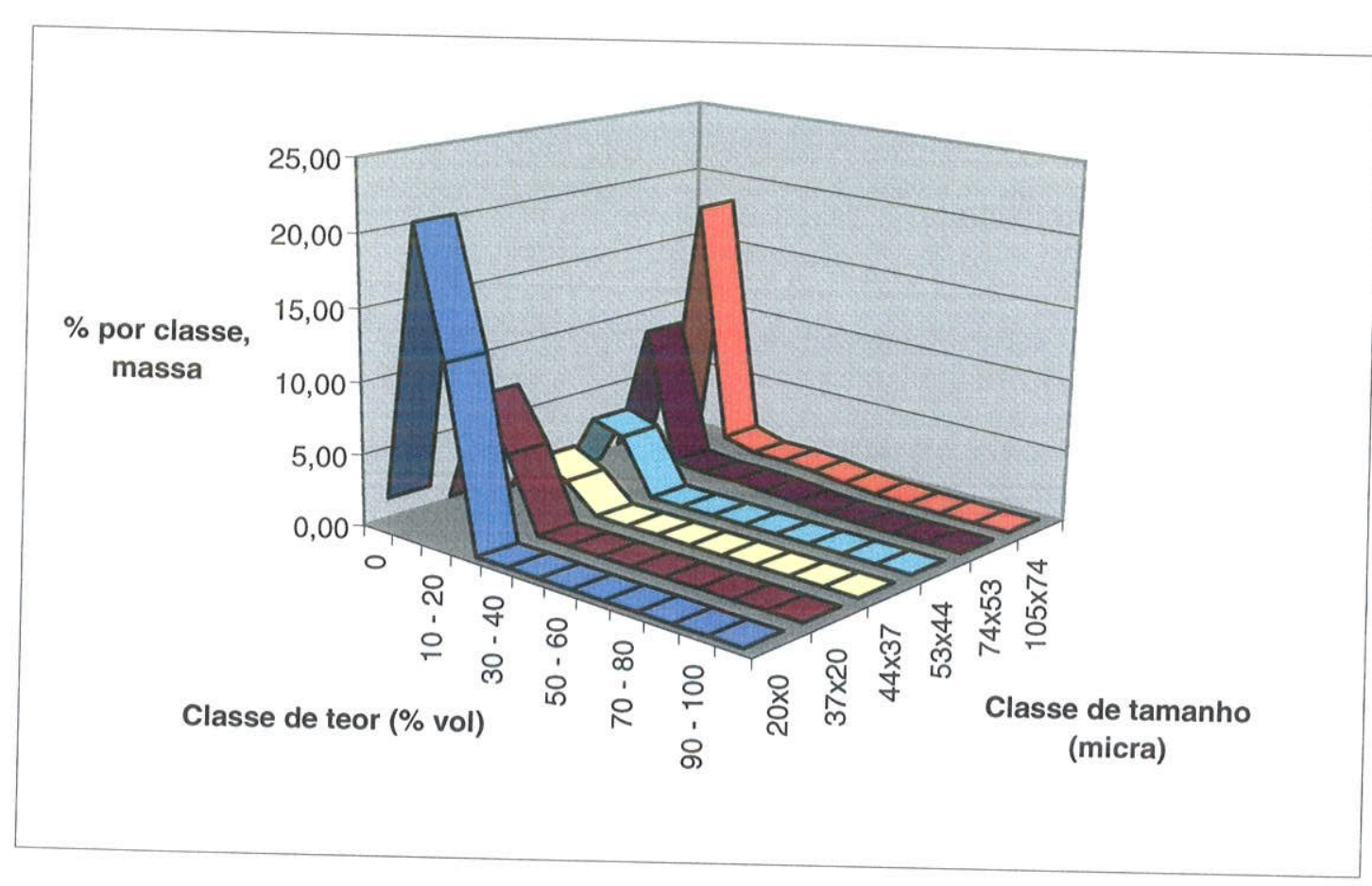

Figura 4.27 - Espectro de liberação, em massa, do minério silexítico. Distribuição bivariada teor/tamanho. Liberação em massa condicional por tamanho da fração mais fina $(-20 \mu \mathrm{m})$ assumida como igual à da fração granulométrica mais próxima.

Uma vez que esse diagrama depende da distribuição granulométrica da amostra, essa planilha pode ser utilizada para prever a mesma distribuição em diferentes condições de cominuição (e portanto de distribuição de tamanhos de partículas) da amostra. A limitação, nesse caso específico, é que a liberação da monazita absolutamente não foi atingida até $20 \mu \mathrm{m}$, de maneira que mesmo obtendose uma distribuição granulométrica muito mais fina para esse minério, a sua liberação, que deve ser melhor a partir de tamanhos de partícula menores, não será calculada apropriadamente. O óbvio seria dar continuidade aos estudos de liberação por análise de imagem até partículas muito mais finas; uma estimativa empírica, com base nas muitas imagens e observações de monazita efetuadas no decorrer desse trabalho, é que até $0,1 \mu \mathrm{m}$ possivelmente poder-se-ia atingir uma liberação razoável, mesmo que não total. Mas as dificuldades nesse sentido são muito grandes. Primeiramente, e essa talvez seja a maior dificuldade, é quase impossível obter uma fração granulométrica com tamanho de partícula bem delimitado abaixo de $20 \mu \mathrm{m}$; apesar de existirem peneiras especiais (até $5 \mu \mathrm{m}$ ), elas são extremamente delicadas, muito caras e com baixíssimo rendimento. $\mathrm{O}$ embutimento das partículas nessas frações, supondo-se que puderam ser geradas dentro das severas especificações necessárias, seria muito 
dificil, uma vez que sua molhabilidade não é boa, tendo como conseqüência partículas aglutinadas, em contato, que introduziriam um erro grande nas medições. A obtenção dessas imagens, por fim, seria outro desafio: apesar do MEV gerar excelentes imagens em aumentos compatíveis com o tamanho das partículas (como exemplo, uma fração de tamanho de partícula de 5 a $10 \mu \mathrm{m}$ requereria um aumento de 5.000 vezes, no MEV utilizado), o foco das imagens para aquisição automática não seria suficientemente bom para uma análise de imagem acurada, exigindo aquisição manual das imagens. Todos esses problemas poderiam ser enfrentados com alguma chance de êxito nos resultados, mas na prática teriam pouco sentido, uma vez que $20 \mu \mathrm{m}$ representa um limite para processamento físico de minérios para praticamente todas as operações unitárias, sem entrar nos aspectos econômicos de cominuição ultrafina de um minério extremamente duro e abrasivo como esse.

Em termos de aplicaçâo prática, os gráfico das Figuras 4.28 a 4.30, derivados da liberação bivariada, correlacionam a previsão de recuperação da monazita, o seu teor no concentrado e o descarte de massa associado, considerados os dados mais relevantes para processo. Esses diagramas prevêem separação ideal. Pelo gráfico da Figura 4.28 fica claro que o teor de monazita no minério é de aproximadamente $15 \%$, correspondente ao teor com recuperação de $100 \%$ da monazita. A essa recuperação é possível um descarte de massa muito pequeno, de menos de $5 \%$, como pode ser visto na Figura 4.29. Isso se deve ao número muito reduzido de partículas que contêm apenas ganga, Figura 4.27. Os diagramas das três figuras também deixam claro a péssima liberação da monazita; qualquer incremento no teor de monazita num eventual concentrado, ou maior descarte de massa no processo, implica em menor recuperação de monazita. Como exemplo, é possivel prever que um concentrado com teor de monazita da ordem de $40 \%$ só recupera por volta de $40 \%$ da monazita total, mas permite um descarte de massa da ordem de $85 \%$. Uma recuperação de monazita melhor, por exemplo $70 \%$, apesar de ainda permitir o descarte de mais de $50 \%$, implica num teor de monazita no concentrado de apenas $25 \%$. 


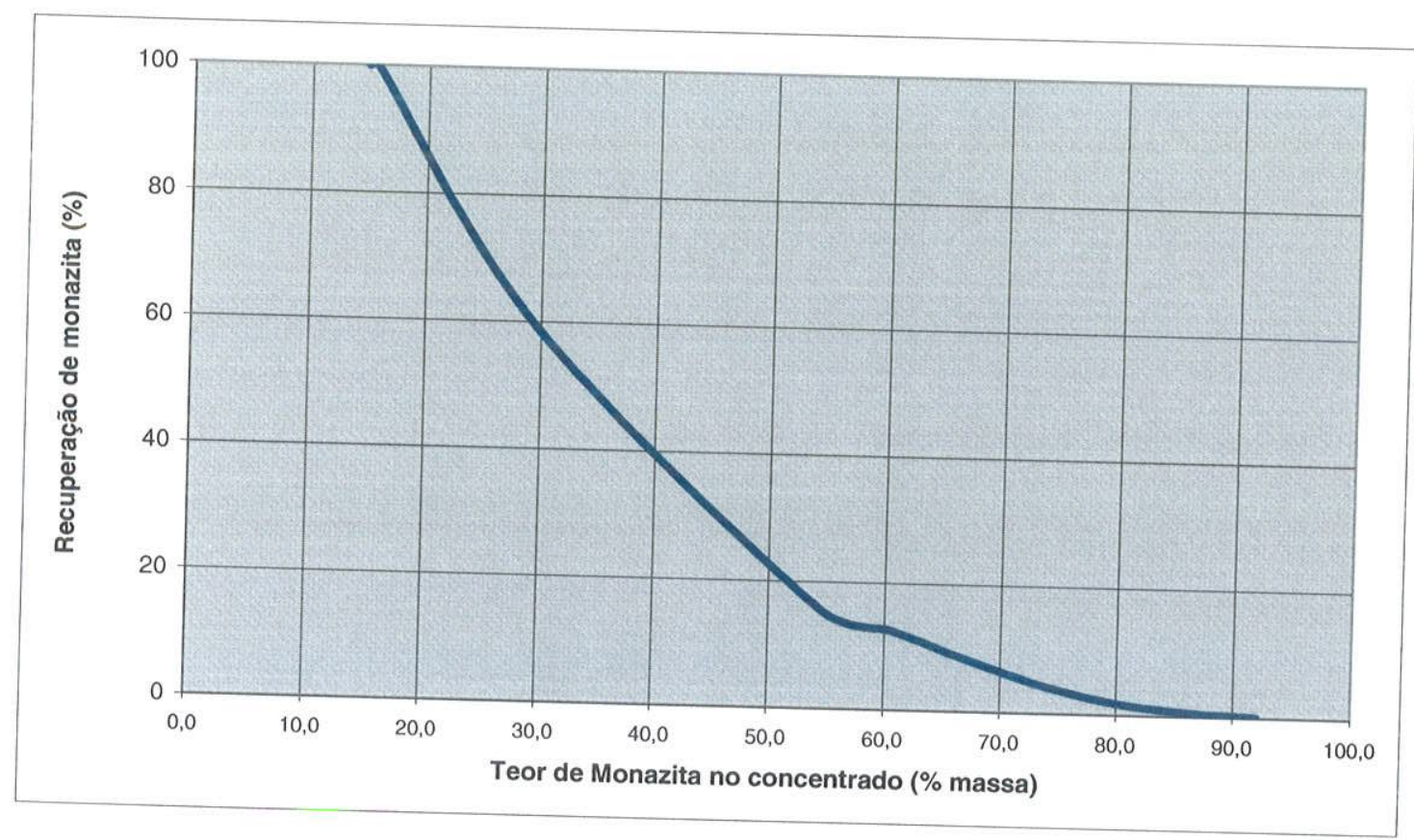
Figura 4.28 - Recuperação de monazita em função do teor de monazita no
concentrado. Minério silexítico.

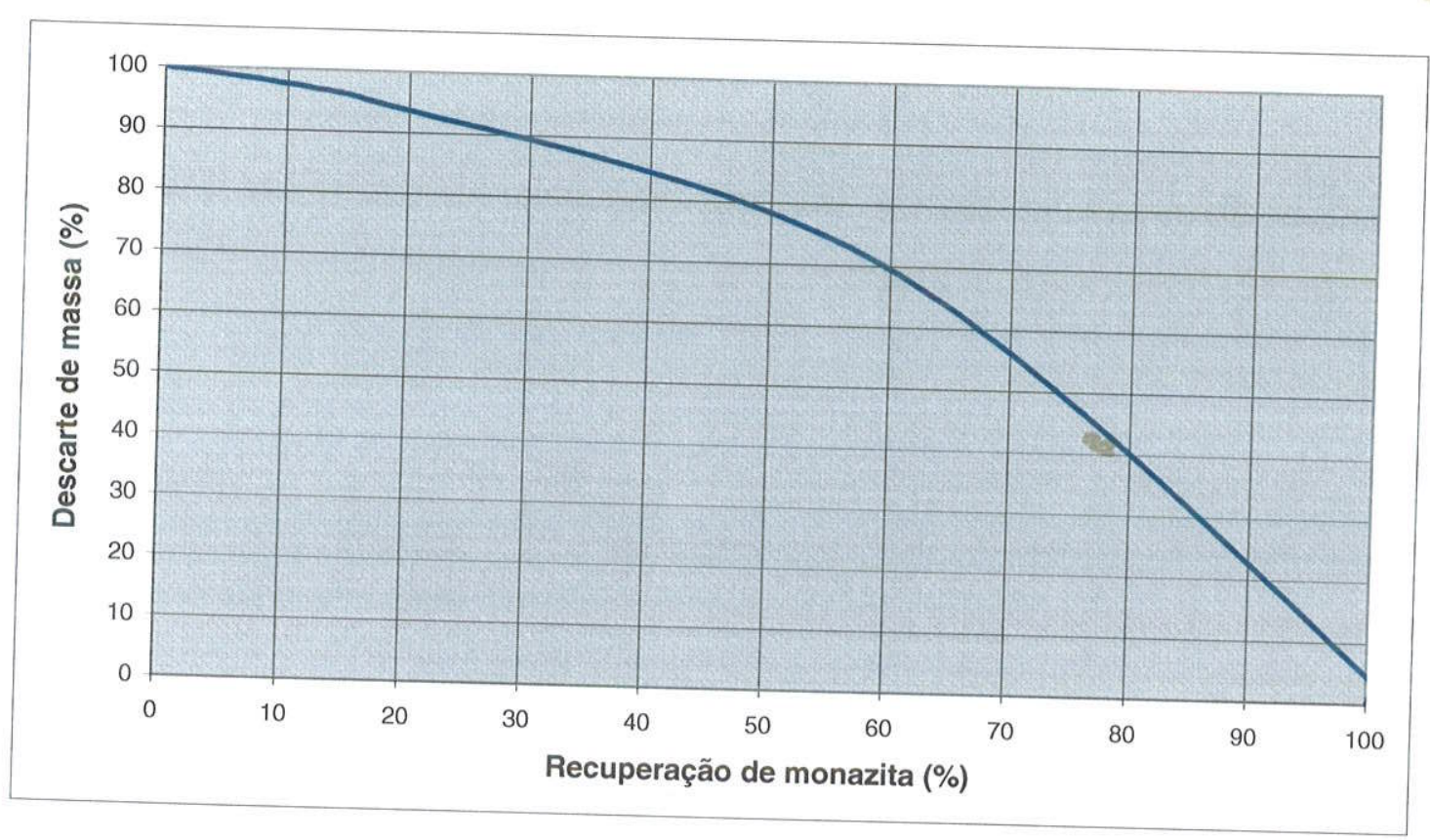

Figura 4.29 - Descarte de massa em função da recuperação de monazita. Minério
silexítico. 


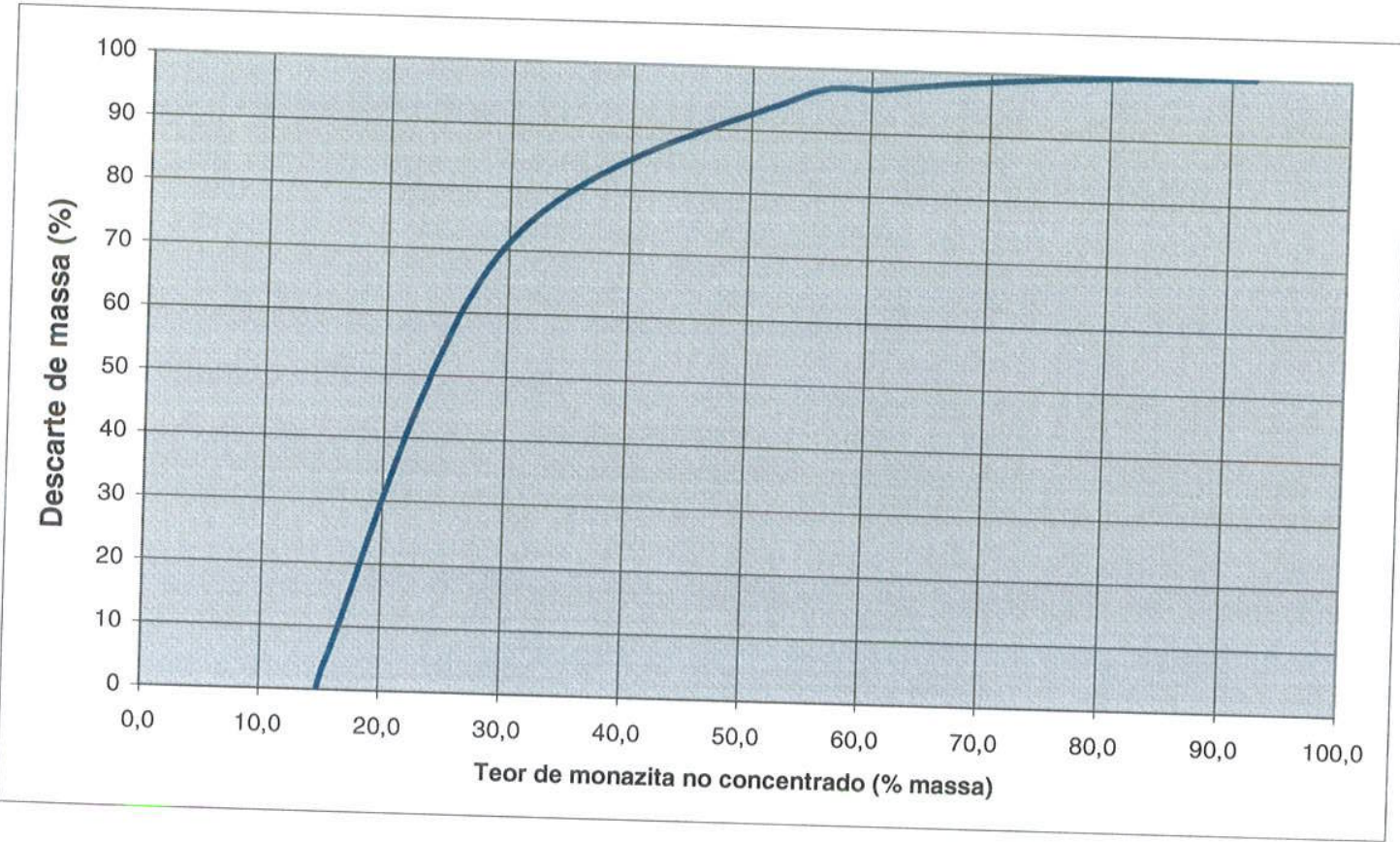

Figura 4.30 - Descarte de massa em função do teor de monazita no concentrado.
Minério silexítico. 


\section{Minério Laterítico}

A Tabela 4.21 apresenta a distribuição de tamanho de partícula do minério laterítico (100\% abaixo de $105 \mu \mathrm{m})$, e a Tabela 4.22 a distribuição em leves e pesados, em relação ao bromofórmio de densidade 2,89 .

Tabela 4.21 - Distribuição de tamanho de partículas do minério silexítico (\% massa).

\begin{tabular}{cccc}
\hline $\begin{array}{c}\text { Peneira } \\
(\mathrm{mm})\end{array}$ & Retido (\%) & $\begin{array}{c}\text { Retido } \\
\text { Acumulado (\%) }\end{array}$ & $\begin{array}{c}\text { Passante } \\
\text { Acumulado (\%) }\end{array}$ \\
\hline 0,074 & 11,26 & 11,26 & 88,74 \\
0,053 & 15,15 & 26,41 & 73,59 \\
0,044 & 9,36 & 35,77 & 64,23 \\
0,037 & 5,33 & 41,10 & 58,90 \\
0,020 & 15,38 & 56,48 & 43,52 \\
$-0,020$ & 43,52 & 100,00 & - \\
\hline
\end{tabular}

Tabela 4.22 - Distribuição por densidade, em relação ao bromofórmio (\% massa).

\begin{tabular}{ccc}
\hline Fração $(\mu \mathrm{m})$ & Flutuado & Afundado \\
\hline $105 \times 74$ & 35,61 & 64,39 \\
$74 \times 53$ & 36,97 & 63,03 \\
$53 \times 44$ & 13,87 & 86,13 \\
$44 \times 37$ & 1,50 & 98,50 \\
$37 \times 20$ & 0,04 & 99,96 \\
\hline
\end{tabular}

A Tabela 4.23 quantifica a separação por suscetibilidade magnética, e a Tabela 4.24 relaciona todas as frações e seus produtos à amostra de cabeça. As Tabelas 4.25 a 4.29 apresentam os resultados de análises químicas $\left(\mathrm{TR}_{2} \mathrm{O}_{3}\right.$ e $\mathrm{Fe}_{2} \mathrm{O}_{3}$ total) de todos os produtos com quantidade suficiente para análise, e quanto isso representa dentro da fração granulométrica e da amostra de cabeça, levando-se em conta os balanços da Tabelas 4.21 a 4.24 . Os totais por produto, fração e amostra de cada tabela referemse, respectivamente, ao medido na fração (granuloquimica), ao calculado pelas análises apresentadas na respectiva tabela e à contribuição da fração no cálculo da cabeça composta final. As Tabelas 4.30 e 4.31, por sua vez, organizam melhor esses 
dados, mostrando a distribuição de, respectivamente, $\mathrm{TR}_{2} \mathrm{O}_{3}$ e $\mathrm{Fe}_{2} \mathrm{O}_{3}$ de todo o minério laterítico. $\mathrm{O}$ teor de $\mathrm{TR}_{2} \mathrm{O}_{3}$ medido na amostra de cabeça do minério silexítico é de $8,39 \%$ (duplicata $8,43 \%$ ), e nos finos (abaixo de $0,020 \mathrm{~mm}$ ) é de $12,38 \%$ (duplicata $11,66 \%$ ), em massa. $\mathrm{Fe}_{2} \mathrm{O}_{3}$ foi medido como sendo $23,73 \%$ na amostra de cabeça e $24,79 \%$ nos finos.

Tabela 4.23 - Distribuição por suscetibilidade magnética das frações afundadas minério laterítico (\% em massa, condicional por tamanho).

\begin{tabular}{lccccc}
\hline Fração $(\mu \mathrm{m})$ & $105 \times 74$ & $74 \times 53$ & $53 \times 44$ & $44 \times 37$ & $37 \times 20$ \\
\hline Mag. Imã mão & 31,09 & 27,65 & 20,60 & 15,69 & 12,15 \\
Mag. 0,1 A & 3,19 & 7,07 & 0,54 & 1,49 & 2,61 \\
Mag. 0,3 A & 7,91 & 10,44 & 3,70 & 4,88 & 1,48 \\
Mag. 0,5 A & 9,04 & 12,87 & 14,55 & 18,53 & 11,01 \\
Mag. 0,8 A & 18,09 & 16,42 & 16,66 & 32,79 & 48,48 \\
Mag. 1,0 A & 7,67 & 6,06 & 12,12 & 11,56 & 2,37 \\
Mag. 1,5 A & 3,94 & 4,96 & 13,91 & 9,28 & 15,71 \\
Mag. 1,85 A & 2,72 & 4,52 & 5,71 & 3,46 & 0,32 \\
Não Mag. 1,85 A & 16,34 & 10,01 & 12,21 & 2,34 & 5,87 \\
\hline \multicolumn{1}{c}{ Total } & 100,0 & 100,0 & 100,0 & 100,0 & 100,0 \\
\hline
\end{tabular}

Tabela 4.24 - Distribuiçăo por densidade e por suscetibilidade magnética das frações acima de $20 \mu \mathrm{m}$, minério laterítico (\% em massa, em relação ao total da amostra). Fração $-20 \mu$ corresponde aos $43,52 \%$ restantes.

\begin{tabular}{|c|c|c|c|c|c|c|}
\hline $\begin{array}{c}\text { Fração } \\
(\mu \mathrm{m})\end{array}$ & $105 \times 74$ & $74 \times 53$ & $53 \times 44$ & $44 \times 37$ & $37 \times 20$ & Total \\
\hline Flutuado & 4,01 & 5,60 & 1,30 & 0,08 & 0,01 & 11,00 \\
\hline Af. Mag. Imã mão & 2,25 & 2,64 & 1,66 & 0,82 & 1,87 & 9,25 \\
\hline Af. Mag. 0,1 A & 0,23 & 0,68 & 0,04 & 0,08 & 0,40 & 1,43 \\
\hline Af. Mag. 0,3 A & 0,57 & 1,00 & 0,30 & 0,26 & 0,23 & 2,35 \\
\hline Af. Mag. 0,5 A & 0,66 & 1,23 & 1,17 & 0,97 & 1,69 & 5,72 \\
\hline Af. Mag. 0,8 A & 1,31 & 1,57 & 1,34 & 1,72 & 7,45 & 13,39 \\
\hline Af. Mag. 1,0 A & 0,56 & 0,58 & 0,98 & 0,61 & 0,36 & 3,08 \\
\hline Af. Mag. 1,5 A & 0,29 & 0,47 & 1,12 & 0,49 & 2,41 & 4,78 \\
\hline Af. Mag. 1,85 A & 0,20 & 0,43 & 0,46 & 0,18 & 0,05 & 1,32 \\
\hline Af. Não Mag. 1,85 A & 1,18 & 0,96 & 0,98 & 0,12 & 0,90 & 4,15 \\
\hline Total & 11,26 & 15,15 & 9,36 & 5,33 & 15,38 & 56,48 \\
\hline
\end{tabular}


Tabela 4.25 - Teor de $\mathrm{TR}_{2} \mathrm{O}_{3}$ e $\mathrm{Fe}_{2} \mathrm{O}_{3}$ (total), em \% por peso, na fração $105 \times 74 \mu \mathrm{m}$, e balanço de distribuiçäo dos elementos na fração e na amostra total.

\begin{tabular}{lcccccc}
\hline Produto & \multicolumn{3}{c}{$\mathrm{TR}_{2} \mathrm{O}_{3}$} & \multicolumn{4}{c}{$\mathrm{Fe}_{2} \mathrm{O}_{3}$} \\
& No produto & $\mathrm{Na} \mathrm{fração}$ & $\mathrm{Na}$ amostra & No produto & $\mathrm{Na}$ fração & Na amostra \\
\hline Flutuado & 1,54 & 0,55 & 0,06 & 4,55 & 1,62 & 0,18 \\
Ímã de Mão & 0,64 & 0,13 & 0,01 & 60,86 & 12,18 & 1,37 \\
0,1 A & 4,85 & 0,10 & 0,01 & 31,67 & 0,65 & 0,07 \\
0,3 A & 1,79 & 0,09 & 0,01 & 33,26 & 1,69 & 0,19 \\
0,5 A & 1,41 & 0,08 & 0,01 & 34,73 & 2,02 & 0,23 \\
0,8 A & 3,00 & 0,35 & 0,04 & 36,73 & 4,28 & 0,48 \\
1,0 A & 7,82 & 0,39 & 0,04 & 19,28 & 0,95 & 0,11 \\
1,5 A & 6,89 & 0,17 & 0,02 & 5,63 & 0,14 & 0,02 \\
1,85 A & 6,82 & 0,12 & 0,01 & 3,16 & 0,06 & 0,01 \\
Não-Magnético & 6,03 & 0,63 & 0,07 & 0,98 & 0,10 & 0,01 \\
\hline Total & 4,02 & 2,61 & 0,29 & 25,12 & 23,70 & 2,67 \\
\hline
\end{tabular}

Tabela 4.26 - Teor de $\mathrm{TR}_{2} \mathrm{O}_{3}$ e $\mathrm{Fe}_{2} \mathrm{O}_{3}$ (total), em \% por peso, na fraçăo $74 \times 53 \mu \mathrm{m}$, e balanço de distribuição dos elementos na fração e na amostra total.

\begin{tabular}{lccc|ccc}
\hline Produto & \multicolumn{3}{c|}{$\mathrm{TR}_{2} \mathrm{O}_{3}$} & & \multicolumn{3}{c}{$\mathrm{Fe}_{2} \mathrm{O}_{3}$} \\
& No produto & $\mathrm{Na}$ fração & $\mathrm{Na}$ amostra & No produto & $\mathrm{Na}$ fração & Na amostra \\
\hline Flutuado & 1,85 & 0,68 & 0,10 & 4,60 & 1,70 & 0,26 \\
Imã de Mão & 0,78 & 0,14 & 0,02 & 68,15 & 11,88 & 1,80 \\
0,1 A & 4,39 & 0,20 & 0,03 & 34,19 & 1,52 & 0,23 \\
0,3 A & 3,67 & 0,24 & 0,04 & 35,56 & 2,34 & 0,35 \\
0,5 A & 0,54 & 0,04 & 0,01 & 38,30 & 3,11 & 0,47 \\
0,8 A & 1,09 & 0,11 & 0,02 & 22,93 & 2,37 & 0,36 \\
1,0 A & 7,78 & 0,30 & 0,05 & 14,42 & 0,55 & 0,08 \\
1,5 A & 10,11 & 0,32 & 0,05 & 6,27 & 0,20 & 0,03 \\
1,85 A & 5,81 & 0,17 & 0,03 & 4,18 & 0,12 & 0,02 \\
Não-Magnético & 6,45 & 0,41 & 0,06 & 1,15 & 0,07 & 0,01 \\
\hline Total & 3,42 & 2,60 & 0,39 & 25,85 & 23,86 & 3,62 \\
\hline
\end{tabular}


Tabela 4.27 - Teor de $\mathrm{TR}_{2} \mathrm{O}_{3}$ e $\mathrm{Fe}_{2} \mathrm{O}_{3}$ (total), em \% por peso, na fração $53 \times 44 \mu \mathrm{m}$, e balanço de distribuição dos elementos na fração e na amostra total.

\begin{tabular}{lccc|ccc}
\hline Produto & \multicolumn{3}{c|}{$\mathrm{TR}_{2} \mathrm{O}_{3}$} & \multicolumn{3}{c}{$\mathrm{Fe}_{2} \mathrm{O}_{3}$} \\
& No produto & $\mathrm{Na}$ fração & $\mathrm{Na}$ amostra & No produto & $\mathrm{Na}$ fração & Na amostra \\
\hline Flutuado & 2,79 & 0,39 & 0,04 & 5,74 & 0,80 & 0,07 \\
Ímã de Mão & 0,92 & 0,16 & 0,02 & 63,39 & 11,25 & 1,05 \\
0,1 A & 1,69 & 0,01 & 0,00 & 31,44 & 0,15 & 0,01 \\
0,3 A & 1,79 & 0,06 & 0,01 & 35,56 & 1,13 & 0,11 \\
0,5 A & 2,09 & 0,26 & 0,02 & 26,74 & 3,35 & 0,31 \\
0,8 A & 4,26 & 0,61 & 0,06 & 24,56 & 3,52 & 0,33 \\
1,0 A & 7,70 & 0,80 & 0,08 & 13,26 & 1,38 & 0,13 \\
1,5 A & 9,88 & 1,18 & 0,11 & 5,53 & 0,66 & 0,06 \\
1,85 A & 6,68 & 0,33 & 0,03 & 4,22 & 0,21 & 0,02 \\
Não-Magnético & 6,91 & 0,73 & 0,07 & 1,59 & 0,17 & 0,02 \\
\hline Total & 3,99 & 4,53 & 0,42 & 21,95 & 22,62 & 2,12 \\
\hline
\end{tabular}

Tabela 4.28 - Teor de $\mathrm{TR}_{2} \mathrm{O}_{3}$ e $\mathrm{Fe}_{2} \mathrm{O}_{3}$ (total), em \% por peso, na fração $44 \times 37 \mu \mathrm{m}$, e balanço de distribuição dos elementos na fração e na amostra total.

\begin{tabular}{lccc|ccc}
\hline Produto & \multicolumn{3}{c}{$\mathrm{TR}_{2} \mathrm{O}_{3}$} & \multicolumn{3}{c}{$\mathrm{Fe}_{2} \mathrm{O}_{3}$} \\
& No produto & $\mathrm{Na}$ fração & $\mathrm{Na}$ amostra & No produto & $\mathrm{Na}$ fração & Na amostra \\
\hline Flutuado & 2,80 & 0,04 & 0,00 & 9,62 & 0,14 & 0,01 \\
Ímã de Mão & 1,28 & 0,20 & 0,01 & 58,48 & 9,03 & 0,48 \\
0,1 A & 5,16 & 0,08 & 0,00 & 33,45 & 0,49 & 0,03 \\
0,3 A & 3,13 & 0,15 & 0,01 & 32,92 & 1,58 & 0,08 \\
0,5 A & 4,15 & 0,76 & 0,04 & 19,52 & 3,56 & 0,19 \\
0,8 A & 5,56 & 1,80 & 0,10 & 13,19 & 4,26 & 0,23 \\
1,0 A & 6,17 & 0,70 & 0,04 & 11,66 & 1,33 & 0,07 \\
1,5 A & 6,15 & 0,56 & 0,03 & 5,58 & 0,51 & 0,03 \\
1,85 A & 5,23 & 0,18 & 0,01 & 5,82 & 0,20 & 0,01 \\
Não-Magnético & 2,61 & 0,06 & 0,00 & 4,22 & 0,10 & 0,01 \\
\hline Total & 4,44 & 4,52 & 0,24 & 25,12 & 21,21 & 1,13 \\
\hline
\end{tabular}


Tabela 4.29 - Teor de $\mathrm{TR}_{2} \mathrm{O}_{3}$ e $\mathrm{Fe}_{2} \mathrm{O}_{3}$ (total), em \% por peso, na fração $37 \times 20 \mu \mathrm{m}$ e dos finos $(-20 \mu \mathrm{m})$, e balanço de distribuiçăo dos elementos na fração e na amostra total.

\begin{tabular}{|c|c|c|c|c|c|c|}
\hline Produto & No produto & $\begin{array}{l}\mathrm{TR}_{2} \mathrm{O}_{3} \\
\mathrm{Na} \text { fração }\end{array}$ & $\mathrm{Na}$ amostra & No produto & $\begin{array}{l}\mathrm{Fe}_{2} \mathrm{O}_{3} \\
\mathrm{Na} \text { fração }\end{array}$ & $\mathrm{Na}$ amostra \\
\hline Flutuado & n.a. & 0,00 & 0,00 & n.a. & 0,00 & 0,00 \\
\hline Ímã de Mão & 0,95 & 0,12 & 0,02 & 44,30 & 5,38 & 0,83 \\
\hline $0,1 \mathrm{~A}$ & 3,94 & 0,10 & 0,02 & 31,66 & 0,83 & 0,13 \\
\hline $0,3 \mathrm{~A}$ & 3,08 & 0,05 & 0,01 & 31,03 & 0,46 & 0,07 \\
\hline $0,5 \mathrm{~A}$ & 3,48 & 0,38 & 0,06 & 33,23 & 3,66 & 0,56 \\
\hline $0,8 \mathrm{~A}$ & 8,07 & 3,91 & 0,60 & 17,16 & 8,32 & 1,28 \\
\hline $1,0 \mathrm{~A}$ & 9,62 & 0,23 & 0,03 & 7,46 & 0,18 & 0,03 \\
\hline $1,5 \mathrm{~A}$ & 7,02 & 1,10 & 0,17 & 3,69 & 0,58 & 0,09 \\
\hline $1,85 \mathrm{~A}$ & 5,25 & 0,02 & 0,00 & 1,89 & 0,01 & 0,00 \\
\hline Não-Magnético & 4,15 & 0,24 & 0,04 & 1,41 & 0,08 & 0,01 \\
\hline$-20 \mu \mathrm{m}$ & $12,38^{*}$ & $\cdots$ & 5,39 & 24,49 & $\overline{---}$ & 10,66 \\
\hline
\end{tabular}

Tabela 4.30 - Balanço metalúrgico $\left(\mathrm{TR}_{2} \mathrm{O}_{3}, \%\right.$ massa) para o minério laterítico, e distribuição por tamanho de partícula e densidade e/ou susceptibilidade magnética (negrito, \% em relação ao total da amostra, itálico, \% massa).

\begin{tabular}{lccccccccc}
\hline \multicolumn{1}{c}{ Fração $(\mu \mathrm{m})$} & $105 \times 74$ & $74 \times 53$ & $53 \times 44$ & $44 \times 37$ & $37 \times 20$ & -20 & Total & Distr. \\
\hline Flutuado & 0,06 & 0,10 & 0,04 & 0,00 & 0,00 & $\ldots-$ & 0,20 & 2,65 \\
Mag. Imâ mão & 0,01 & 0,02 & 0,02 & 0,01 & 0,02 & $\ldots$ & 0,08 & $\mathbf{1 , 0 2}$ \\
Mag. 0,1 A & 0,01 & 0,03 & 0,00 & 0,00 & 0,02 & $\ldots-$ & 0,06 & $\mathbf{0 , 8 0}$ \\
Mag. 0,3 A & 0,01 & 0,04 & 0,01 & 0,01 & 0,01 & $\ldots$ & 0,07 & $\mathbf{0 , 8 7}$ \\
Mag. 0,5 A & 0,01 & 0,01 & 0,02 & 0,04 & 0,06 & $\ldots-$ & 0,14 & $\mathbf{1 , 8 2}$ \\
Mag. 0,8 A & 0,04 & 0,02 & 0,06 & 0,10 & 0,60 & $\ldots$ & 0,81 & 10,54 \\
Mag. 1,0 A & 0,04 & 0,05 & 0,08 & 0,04 & 0,03 & $\ldots$ & 0,24 & $\mathbf{3 , 0 7}$ \\
Mag. 1,5 A & 0,02 & 0,05 & 0,11 & 0,03 & 0,17 & $\ldots$ & 0,38 & $\mathbf{4 , 9 1}$ \\
Mag. 1,85 A & 0,01 & 0,03 & 0,03 & 0,01 & 0,00 & $\ldots$ & 0,08 & $\mathbf{1 , 0 6}$ \\
Não Mag. 1,85 A & 0,07 & 0,06 & 0,07 & 0,00 & 0,04 & - & 0,24 & $\mathbf{3 , 1 4}$ \\
\hline \multicolumn{1}{c}{ Total } & 0,29 & 0,39 & 0,42 & 0,24 & 0,95 & 5,39 & 7,69 & $\mathbf{7 0 , 1 1}$ \\
\hline Distribuição & $\mathbf{3 , 8 3}$ & $\mathbf{5 , 1 2}$ & $\mathbf{5 , 5 2}$ & $\mathbf{3 , 1 3}$ & $\mathbf{1 2 , 2 9}$ & $\mathbf{7 0 , 1 1}$ & $\mathbf{1 0 0 , 0 0}$ & \\
\hline
\end{tabular}


Tabela 4.31 - Balanço metalúrgico $\left(\mathrm{Fe}_{2} \mathrm{O}_{3}, \%\right.$ massa) para o minério laterítico, e distribuição por tamanho de parícula e densidade e/ou susceptibilidade magnética (negrito, em relação ao total da amostra, itálico, \% massa).

\begin{tabular}{lcccccccc}
\hline \multicolumn{1}{c}{ Fração $(\mu \mathrm{m})$} & $105 \times 74$ & $74 \times 53$ & $53 \times 44$ & $44 \times 37$ & $37 \times 20$ & -20 & Total & Distr. \\
\hline Flutuado & 0,18 & 0,26 & 0,07 & 0,01 & 0,00 & - & 0,52 & $\mathbf{2 , 2 5}$ \\
Mag. Imã mão & 1,37 & 1,80 & 1,05 & 0,48 & 0,83 & -- & 5,53 & $\mathbf{2 3 , 8 6}$ \\
Mag. 0,1 A & 0,07 & 0,23 & 0,01 & 0,03 & 0,13 & -- & 0,47 & $\mathbf{2 , 0 3}$ \\
Mag. 0,3 A & 0,19 & 0,35 & 0,11 & 0,08 & 0,07 & - & 0,81 & $\mathbf{3 , 4 8}$ \\
Mag. 0,5 A & 0,23 & 0,47 & 0,31 & 0,19 & 0,56 & - & 1,76 & $\mathbf{7 , 6 1}$ \\
Mag. 0,8 A & 0,48 & 0,36 & 0,33 & 0,23 & 1,28 & - & 2,68 & $\mathbf{1 1 , 5 5}$ \\
Mag. 1,0 A & 0,11 & 0,08 & 0,13 & 0,07 & 0,03 & -- & 0,42 & $\mathbf{1 , 8 0}$ \\
Mag. 1,5 A & 0,02 & 0,03 & 0,06 & 0,03 & 0,09 & -- & 0,22 & $\mathbf{0 , 9 7}$ \\
Mag. 1,85 A & 0,01 & 0,02 & 0,02 & 0,01 & 0,00 & -- & 0,06 & $\mathbf{0 , 2 4}$ \\
Não Mag. 1,85 A & 0,01 & 0,01 & 0,02 & 0,01 & 0,01 & -- & 0,06 & $\mathbf{0 , 2 4}$ \\
\hline \multicolumn{1}{c}{ Total } & 2,67 & $\mathbf{3 , 6 2}$ & $\mathbf{2 , 1 2}$ & 1,13 & 3,00 & 10,66 & 23,19 & $\mathbf{4 5 , 9 7}$ \\
\hline Distribuição & $\mathbf{1 1 , 5 1}$ & $\mathbf{1 5 , 5 9}$ & $\mathbf{9 , 1 3}$ & $\mathbf{4 , 8 7}$ & $\mathbf{1 2 , 9 2}$ & $\mathbf{4 5 , 9 7}$ & $\mathbf{1 0 0 , 0 0}$ & \\
\hline
\end{tabular}

Observa-se que as terras raras nesse minério são distribuídas de acordo com a granulometria, mas que $70 \%$ do total concentram-se nos finos, equivalendo a $43,52 \%$ da massa. Outro acúmulo ocorre a 0,8 A, concentrando $10,54 \%$ dos OTR, e $13,39 \%$ da massa; na verdade, a maior parte de magnético a $0,8 \mathrm{~A}$ é obtido na fração $37 \times 20 \mu \mathrm{m}$, correspondendo a $7,45 \%$ da massa, mas com teor apenas pouco acima da amostra de cabeça, 8,07\%. Dessa forma, separação magnética não é eficiente para promover concentração de monazita, pelo menos até o bottom size de $20 \mu \mathrm{m}$. E à exceção do corte em $20 \mu \mathrm{m}$, também não ocorre concentração significativa por classe granulométrica, com a distribuição de teores de OTR repetindo a distribuição granulométrica, apesar de pequeno incremento em direção às partículas mais finas.

A mesma conclusão em relação à distribuição de teores e granulométrica pode ser aplicada ao $\mathrm{Fe}$, uma vez que a distribuição de teores de $\mathrm{Fe}_{2} \mathrm{O}_{3}$ praticamente repete a granulométrica, inclusive na fração $-20 \mu \mathrm{m}$. Observa-se, por outro lado, que é possivel concentrar quase $24 \%$ do $\mathrm{Fe}_{2} \mathrm{O}_{3}$ com separação magnética com imã de ferrite, e apenas $9,25 \%$ da massa total, equivalendo por sua vez a apenas $1,02 \%$ de perda de 
OTR. Separações magnéticas em campos mais intensos não promovem remoção de Fe eficaz, e geram perdas consideráveis de terras raras. A remoção maior, no entanto, é nas frações mais grossas, onde a magnetita se concentra, diminuindo consideravelmente com a granulometria.

As Tabelas 4.32 a 4.36 apresentam a mineralogia por fração/produto determinada por difração de raios $X$, apenas qualitativamente. $A$ ordem de enumeração dos minerais corresponde às quantidades obtidas pelo ajuste de escala durante a interpretação, simplesmente mudando a quantidade de cada fase até que visualmente todos os picos estivessem atendidos pelos padrões. Como a superposiçăo de picos é grande, o ruído näo foi subtraído, orientação preferencial não foi evitada ou modelada, entre outras razões, o scaling serve apenas para organizar de alguma forma os dados.

Vermiculita e hidrobiotita proporcionaram o melhor ajuste com os picos (muito provavelmente realçados por orientação preferencial) no início do espectro. No caso da vermiculita, o ajuste foi muito bom, e apenas o mineral aparece antes do devido na ordenaçâo das tabelas abaixo, uma vez que os outros picos além do de aproximadamente $14 \AA$ são bem menores, proporcionalmente (e sem considerar as superposiçōes). No caso da hidrobiotita, o ajuste geralmente foi bom (com as mesmas ressalvas em relação à orientação preferencial e seu posicionamento nas tabelas), mas às vezes os picos no inicio variam ligeiramente (até $0,3 \AA$ ) a sua posição. Como, no entanto, não foi identificada nenhuma fase melhor para interpretação (condizente também com observaçôes por MEV/EDS), principalmente do pico a aproximadamente $12 \AA$, considerou-se a hidrobiotita como representando um conjunto de interestratificados, e sem nenhum interesse maior dentro do escopo desse trabalho. A esperada flogopita nunca pôde ser identificada nessas amostras. 
Alguns produtos afundados não magnéticos a 1,85 A apresentam um pico razoavelmente intenso a $2,92 \AA$, que não resulta de nenhum dos outros minerais interpretados nesses difratogramas. Pela análise dessas frações ao MEV/EDS e pela interpretação dos espectros, assumiu-se que se trata de zirconolita, mesmo que o fit não seja perfeito. A outra possibilidade, pelas análises de DRX com suporte do MEV/EDS, seria a aeschynita-Nd, um mineral aparentemente mal estudado, segundo sua ficha ICDD (1996), e que também apresenta algumas incompatibilidades de composição química. O assunto será aprofundado mais à frente.

Tabela 4.32 - Composição mineralógica, conforme identificada por DRX, da fração $105 \times 74 \mu \mathrm{m}$.

\begin{tabular}{|c|c|}
\hline Produto & Mineralogia \\
\hline Flutuado & $\begin{array}{l}\text { Quartzo, hidrobiotita, goethita, monazita-Ce, fluorapatita, vermiculita, } \\
\text { gorceixita }\end{array}$ \\
\hline Imã de Mão & $\begin{array}{l}\text { Magnetita, hematita, quartzo, ilmenita, fluorapatita, goethita, monazita- } \\
\mathrm{Ce} \text {, gorceixita }\end{array}$ \\
\hline $0,1 \mathrm{~A}$ & $\begin{array}{l}\text { Ilmenita, fluorapatita, quartzo, goethita, anatásio, hematita, vermiculita, } \\
\text { monazita-Ce, gorceixita }\end{array}$ \\
\hline $0,3 \mathrm{~A}$ & $\begin{array}{l}\text { llmenita, goethita, fluorapatita, hematita, gorceixita, quartzo, monazita- } \\
\text { Ce, priderita, bariopirocloro }\end{array}$ \\
\hline $0,5 \mathrm{~A}$ & $\begin{array}{l}\text { Ilmenita, goethita, hematita, fluorapatita, priderita, gorceixita, quartzo, } \\
\text { monazita-Ce }\end{array}$ \\
\hline $0,8 \mathrm{~A}$ & $\begin{array}{l}\text { Goethita, ilmenita, quartzo, anatásio, fluorapatita, hematita, gorceixita, } \\
\text { priderita, barita, monazita-Ce }\end{array}$ \\
\hline $1,0 \mathrm{~A}$ & $\begin{array}{l}\text { Anatásio, goethita, gorceixita, fluorapatita, quartzo, monazita-Ce, } \\
\text { priderita, hematita, ilmenita }\end{array}$ \\
\hline $1,5 \mathrm{~A}$ & $\begin{array}{l}\text { Fluorapatita, quartzo, anatásio, monazitamCe, gorceixita, goethita, } \\
\text { priderita }\end{array}$ \\
\hline $1,85 \mathrm{~A}$ & $\begin{array}{l}\text { Fluorapatita, quartzo, anatásio, monazita-Ce, goethita, gorceixita, } \\
\text { priderita }\end{array}$ \\
\hline Não-Mag. & Fluorapatita, quartzo, monazita-Ce, gorceixita, priderita \\
\hline
\end{tabular}


Tabela 4.33 - Composição mineralógica, conforme identificada por DRX, da fração $74 \times 53 \mu \mathrm{m}$.

\begin{tabular}{|c|c|}
\hline Produto & Mineralogia \\
\hline Flutuado & $\begin{array}{l}\text { Quartzo, goethita, fluorapatita, hidrobiotita, monazita-Ce, vermiculita, } \\
\text { gorceixita }\end{array}$ \\
\hline Imã de Mão & $\begin{array}{l}\text { Magnetita, hematita, ilmenita, quartzo, goethita, fluorapatita, monazita- } \\
\mathrm{Ce} \text {, }\end{array}$ \\
\hline $0,1 \mathrm{~A}$ & $\begin{array}{l}\text { Fluorapatita, ilmenita, quartzo, hematita, monazita-Ce, gorceixita, } \\
\text { vermiculita }\end{array}$ \\
\hline $0,3 \mathrm{~A}$ & $\begin{array}{l}\text { Ilmenita, hematita, fluorapatita, goethita, quartzo, vermiculita, priderita, } \\
\text { gorceixita, anatásio, monazita-Ce }\end{array}$ \\
\hline $0,5 \mathrm{~A}$ & $\begin{array}{l}\text { IImenita, goethita, hematita, quartzo, fluorapatita, priderita, gorceixita, } \\
\text { bariopirocloro, monazita-Ce }\end{array}$ \\
\hline $0,8 \mathrm{~A}$ & $\begin{array}{l}\text { Fluorapatita, goethita, anatásio, quartzo, ilmenita, barita, priderita, } \\
\text { hematita, gorceixita, monazita-Ce, bariopirocloro }\end{array}$ \\
\hline $1,0 \mathrm{~A}$ & $\begin{array}{l}\text { Goethita, fluorapatita, anatásio, quartzo, gorceixita, monazita-Ce, } \\
\text { priderita, hematita, ilmenita }\end{array}$ \\
\hline $1,5 \mathrm{~A}$ & $\begin{array}{l}\text { Quartzo, fluorapatita, monazita-Ce, anatásio, gorceixita, goethita, } \\
\text { priderita, ilmenita }\end{array}$ \\
\hline $1,85 \mathrm{~A}$ & $\begin{array}{l}\text { Fluorapatita, quartzo, monazita-Ce, anatásio, gorceixita, goethita, } \\
\text { priderita }\end{array}$ \\
\hline Não-Mag. & Fluorapatita, quartzo, monazita-Ce, anatásio, gorceixita, zirconolita \\
\hline
\end{tabular}

Tabela 4.34 - Composição mineralógica, conforme identificada por DRX, da fração $53 \times 44 \mu \mathrm{m}$.

\begin{tabular}{|c|c|}
\hline Produto & Mineralogia \\
\hline Flutuado & $\begin{array}{l}\text { Quartzo, hidrobiotita, vermiculita, fluorapatita, goethita, monazita-Ce, } \\
\text { gorceixita }\end{array}$ \\
\hline Imã de Mão & $\begin{array}{l}\text { Magnetita, hematita, ilmenita, quartzo, goethita, fluorapatita, monazita- } \\
\text { Ce }\end{array}$ \\
\hline $0,1 \mathrm{~A}$ & $\begin{array}{l}\text { Quartzo, ilmenita, vermiculita, hematita, fluorapatita, goethita, magnetita, } \\
\text { hidrobiotita, gorceixita, monazitaw Ce, bariopirocloro }\end{array}$ \\
\hline $0,3 \mathrm{~A}$ & $\begin{array}{l}\text { I!menita, quartzo, vermiculita, fluorapatita, goethita, hematita, } \\
\text { hidrobiotita, monazita-Ce, priderita, gorceixita }\end{array}$ \\
\hline $0,5 \mathrm{~A}$ & $\begin{array}{l}\text { Quartzo, ilmenita, vermiculita, hidrobiotita, goethita, hematita, priderita, } \\
\text { fluorapatita, monazita-Ce, gorceixita }\end{array}$ \\
\hline $0,8 \mathrm{~A}$ & $\begin{array}{l}\text { Quartzo, vermiculita, goethita, ilmenita, hidrobiotita, fluorapatita, } \\
\text { priderita, monazita-Ce, gorceixita }\end{array}$ \\
\hline $1,0 \mathrm{~A}$ & $\begin{array}{l}\text { Quartzo, anatásio, vermiculita, goethita, fluorapatita, hidrobiotita, } \\
\text { monazita-Ce, gorceixita, priderita, ilmenita }\end{array}$ \\
\hline $1,5 \mathrm{~A}$ & $\begin{array}{l}\text { Quartzo, fluorapatita, monazita-Ce, anatásio, vermiculita, gorceixita, } \\
\text { goethita, hidrobiotita, priderita }\end{array}$ \\
\hline $1,85 \mathrm{~A}$ & $\begin{array}{l}\text { Quartzo, fluorapatita, vermiculita, monazita-Ce, anatásio, hidrobiotita, } \\
\text { gorceixita, goethita }\end{array}$ \\
\hline Não-Mag. & $\begin{array}{l}\text { Quartzo, fluorapatita, anatásio, monazita-Ce, barita, vermiculita, } \\
\text { hidrobiotita, gorceixita, goethita, zirconolita }\end{array}$ \\
\hline
\end{tabular}


Tabela 4.35 - Composição mineralógica, conforme identificada por DRX, da fração $44 \times 37 \mu \mathrm{m}$.

\begin{tabular}{|c|c|}
\hline Produto & Mineralogia \\
\hline Flutuado & $\begin{array}{l}\text { Quartzo, hidrobiotita, vermiculita, goethita, monazita-Ce, fluorapatita, } \\
\text { gorceixita }\end{array}$ \\
\hline Imã de Mão & $\begin{array}{l}\text { Magnetita, hematita, quartzo, ilmenita, goethita, fluorapatita, monazita- } \\
\mathrm{Ce}\end{array}$ \\
\hline $0,1 \mathrm{~A}$ & $\begin{array}{l}\text { Quartzo, ilmenita, hematita, vermiculita, fluorapatita, goethita, } \\
\text { hidrobiotita, magnetita, monazita-Ce, gorceixita, bariopirocloro }\end{array}$ \\
\hline $0,3 \mathrm{~A}$ & $\begin{array}{l}\text { Quartzo, ilmenita, goethita, vermiculita, fluorapatita, hematita, } \\
\text { hidrobiotita, monazita-Ce, priderita, gorceixita }\end{array}$ \\
\hline $0,5 \mathrm{~A}$ & $\begin{array}{l}\text { Quartzo, vermiculita, hidrobiotita, ilmenita, goethita, fluorapatita, } \\
\text { hematita, monazitamCe, priderita, gorceixita }\end{array}$ \\
\hline $0,8 \mathrm{~A}$ & $\begin{array}{l}\text { Quartzo, vermiculita, hidrobiotita, goethita, fluorapatita, monazita-Ce, } \\
\text { ilmenita, gorceixita, priderita }\end{array}$ \\
\hline $1,0 \mathrm{~A}$ & $\begin{array}{l}\text { Quartzo, vermiculita, fluorapatita, hidrobiotita, goethita, monazita-Ce, } \\
\text { anatásio, gorceixita, priderita, ilmenita }\end{array}$ \\
\hline $1,5 \mathrm{~A}$ & $\begin{array}{l}\text { Quartzo, fluorapatita, vermiculita, monazita- } \mathrm{Ce} \text {, goethita, hidrobiotita, } \\
\text { anatásio, gorceixita, priderita }\end{array}$ \\
\hline $1,85 \mathrm{~A}$ & Quartzo, fluorapatita, monazita-Ce, anatásio, gorceixita, goethita \\
\hline Não-Mag. & Quartzo, fluorapatita, anatásio, monazita-Ce, gorceixita, goethita \\
\hline
\end{tabular}

Tabela 4.36 - Composição mineralógica, conforme identificada por DRX, da fração $37 \times 20 \mu \mathrm{m}$, e dos finos $(-20 \mu \mathrm{m})$.

\begin{tabular}{|c|c|}
\hline Produto & Mineralogia \\
\hline Flutuado & $\begin{array}{l}\text { Quartzo, vermiculita, fluorapatita, goethita, hidrobiotita, anatásio, } \\
\text { monazita-Ce, gorceixita, priderita }\end{array}$ \\
\hline Imã de Mão & $\begin{array}{l}\text { Magnetita, hematita, ilmenita, quartzo, goethita, fluorapatita, monazita- } \\
\mathrm{Ce}\end{array}$ \\
\hline $0,1 \mathrm{~A}$ & $\begin{array}{l}\text { Quartzo, ilmenita, vermiculita, hidrobiotita, fluorapatita, goethita, } \\
\text { hematita, monazita-Ce, magnetita, gorceixita }\end{array}$ \\
\hline $0,3 \mathrm{~A}$ & $\begin{array}{l}\text { Ilmenita, quartzo, vermiculita, goethita, hematita, hidrobiotita, monazita- } \\
\mathrm{Ce} \text {, fluorapatita, gorceixita }\end{array}$ \\
\hline $0,5 \mathrm{~A}$ & $\begin{array}{l}\text { Quartzo, vermiculita, hidrobiotita, ilmenita, goethita, fluorapatita, } \\
\text { hematita, monazita-Ce, priderita, gorceixita }\end{array}$ \\
\hline $0,8 \mathrm{~A}$ & $\begin{array}{l}\text { Quartzo, vermiculita, goethita, hidrobiotita, monazita-Ce, fluorapatita, } \\
\text { anatásio, gorceixita, ilmenita, priderita }\end{array}$ \\
\hline $1,0 \mathrm{~A}$ & $\begin{array}{l}\text { Quartzo, vermiculita, hidrobiotita, anatásio, goethita, monazita-Ce, } \\
\text { fluorapatita, gorceixita, priderita, ilmenita }\end{array}$ \\
\hline $1,5 \mathrm{~A}$ & $\begin{array}{l}\text { Quartzo, fluorapatita, monazita-Ce, vermiculita, anatásio, hidrobiotita, } \\
\text { gorceixita, goethita, priderita }\end{array}$ \\
\hline $1,85 \mathrm{~A}$ & $\begin{array}{l}\text { Quartzo, fluorapatita, vermiculita, anatásio, monazita-Ce, hidrobiotita, } \\
\text { goethita, zirconolita, gorceixita }\end{array}$ \\
\hline Não-Mag. & Quartzo, fluorapatita, monazita-Ce, vermiculita, anatásio, gorceixita \\
\hline$-20 \mu \mathrm{m}$ & $\begin{array}{l}\text { Quartzo, goethita, monazita-Ce, hematita, vermiculita, fluorap } \\
\text { ilmenita, hidrobiotita, anatásio, priderita, gorceixita }\end{array}$ \\
\hline
\end{tabular}


Assim como no minério silexítico, monazita é o carreador de terras raras mais importante. Em termos de forma de ocorrência, ela ainda ocorre em esferóides dispersos na matriz de quartzo, mas essa já é uma forma de ocorrência mais rara. Geralmente a monazita é maciça, apesar de muito porosa. Essa porosidade pode, inclusive, ser responsável pelo baixo fechamento de análises químicas pontuais, como já foi aventado por Pereira (1995). Um exemplo mais extremo dessa porosidade está na imagem da Figura 4.31, e uma monazita porosa muito fina na 4.32. Na Figura 4.33, observa-se a passagem de um esferóide de monazita para o tipo maciço e poroso. Esse tipo de transformação não é comum.

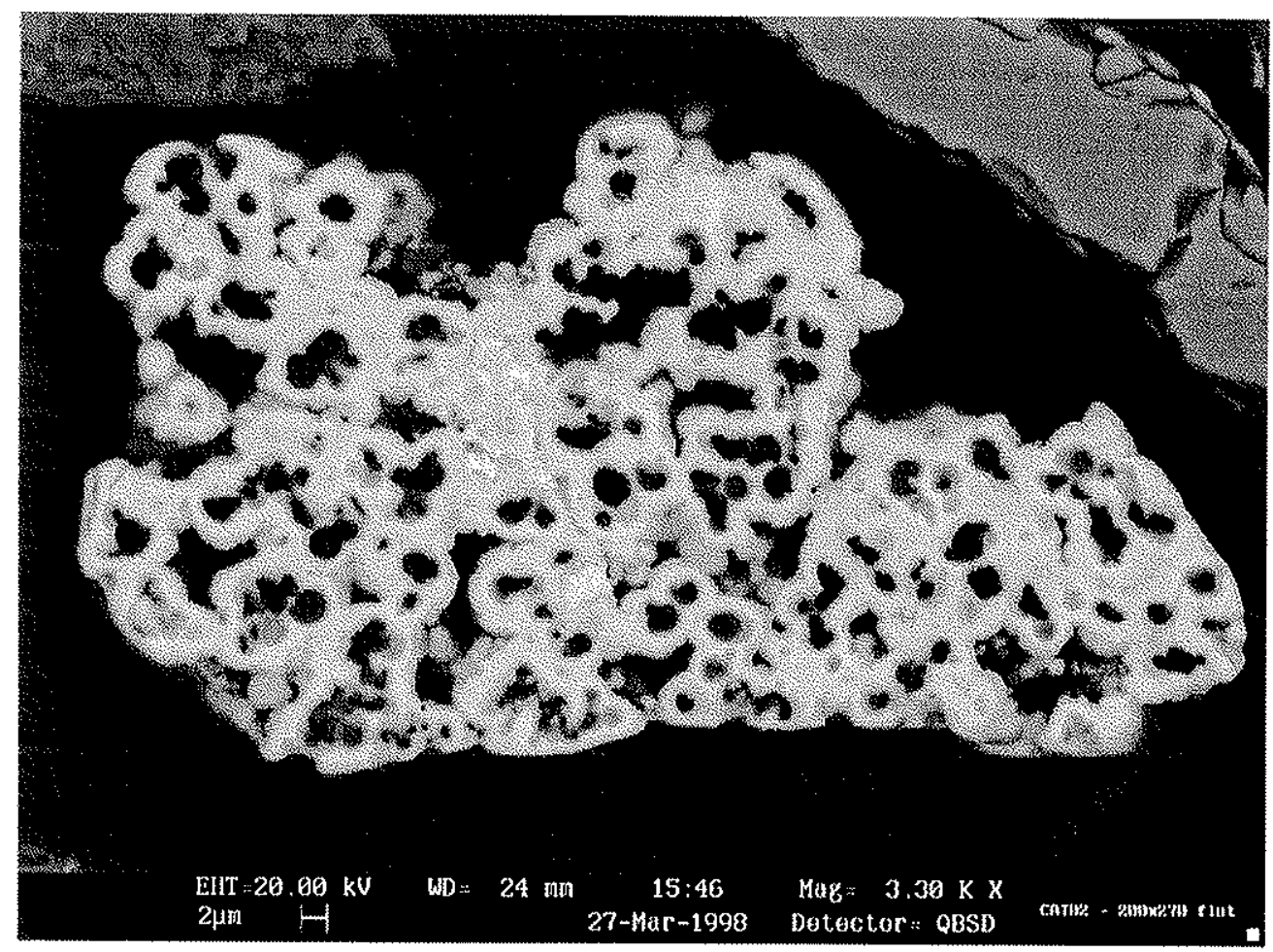

Figura 4.31 - Monazita extremamente porosa. Região mais clara ao centro do grão apresenta alto teor de $\mathrm{Ce}, \mathrm{Ba}$ e $\mathrm{Mn}$ (MEV/BSD). 


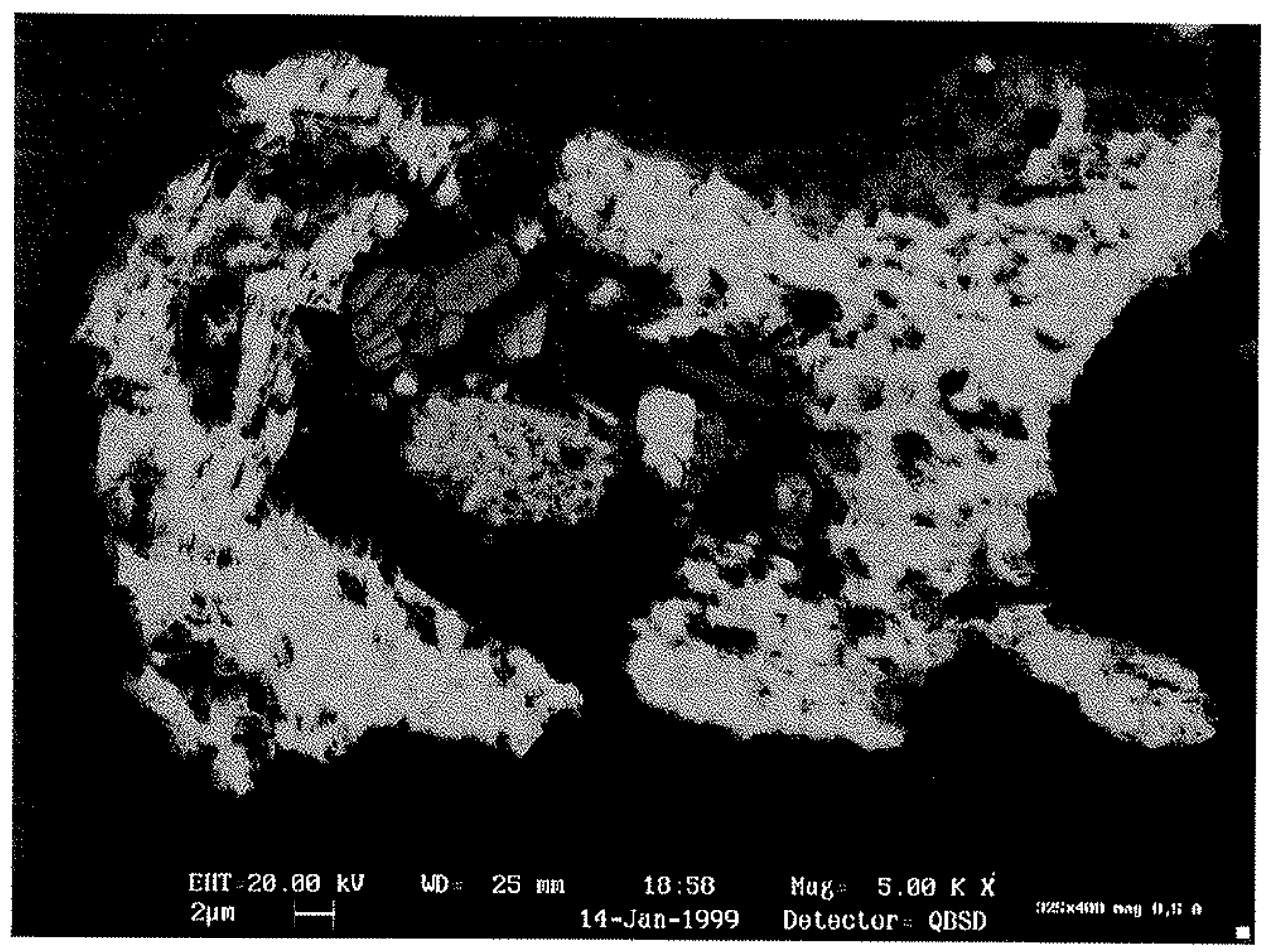

Figura 4.32 - Monazita acicular porosa muito fina (MEV/BSD).

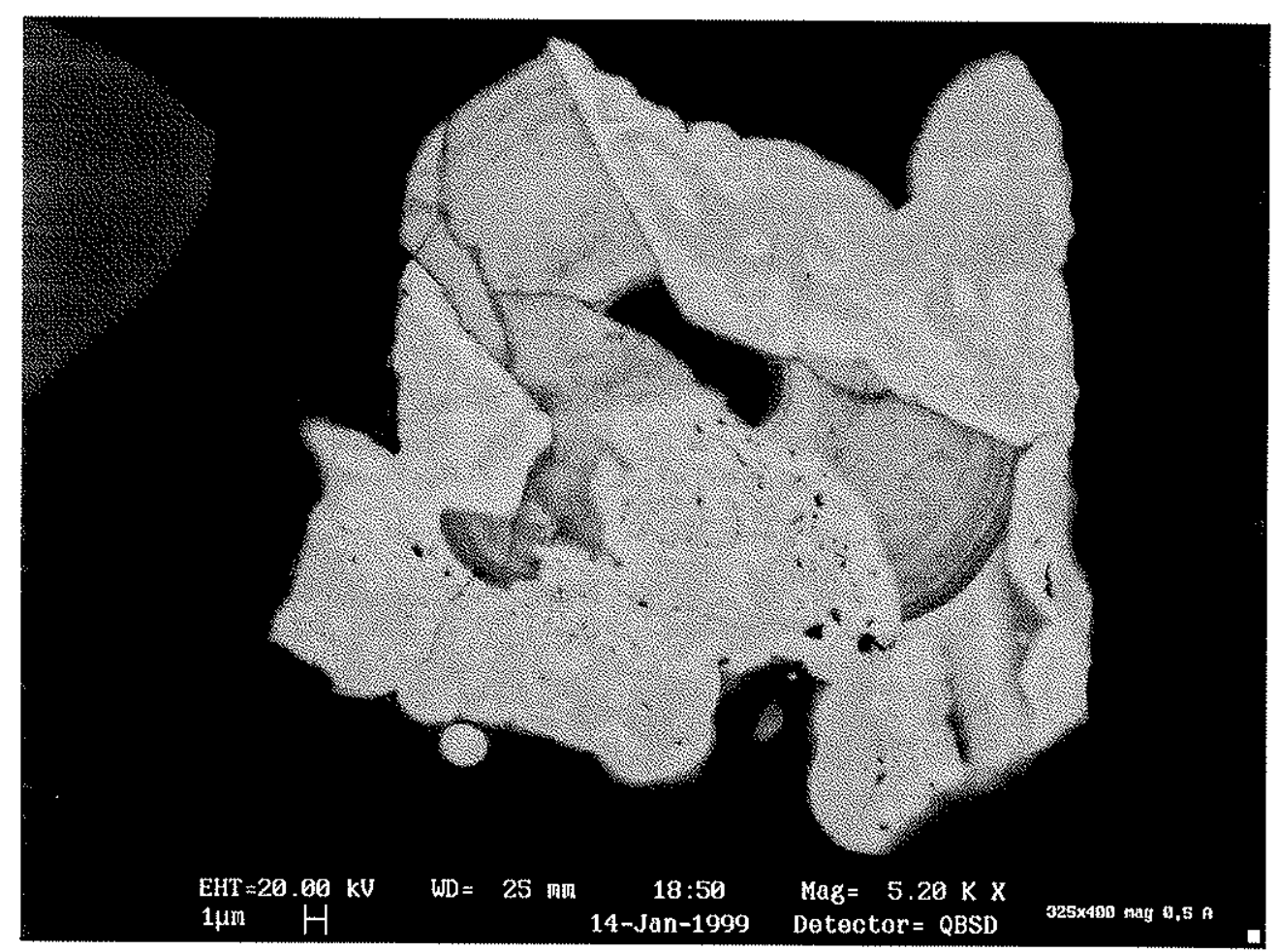

Figura 4.33 - Intercrescimento (ou transformação) de monazita esferoidal para o tipo maciço poroso (MEV/BSD). 
A monazita associa-se a diversos outros minerais da paragênese encontrada no minério laterítico. As associações mais comuns, no entanto, são com apatita, gorceixita e com as fases ferruginosas. As imagens das Figuras 4.34 e 4.35 mostram duas interessantes associações com apatita. No caso da imagem da Figura 4.34, a monazita é nitidamente posterior à apatita mais escura, e anterior e/ou concomitante à mais clara. As dimensões da monazita, nesse caso específico, são da ordem de um $\mu \mathrm{m}$, mas geralmente foram observadas bem menores. Esse seria um exemplo de como uma microanálise de apatita poderia acusar teores mais elevados de ETR pela presença de monazita, se a imagem utilizada para direcionar o feixe não for acurada o suficiente para a sua distinção. $\mathrm{Na}$ imagem da Figura 4.35, observa-se o que se assemelha a um cristal de monazita aparentemente tabular, apesar de muito corroído e quebrado, envolto em apatita.

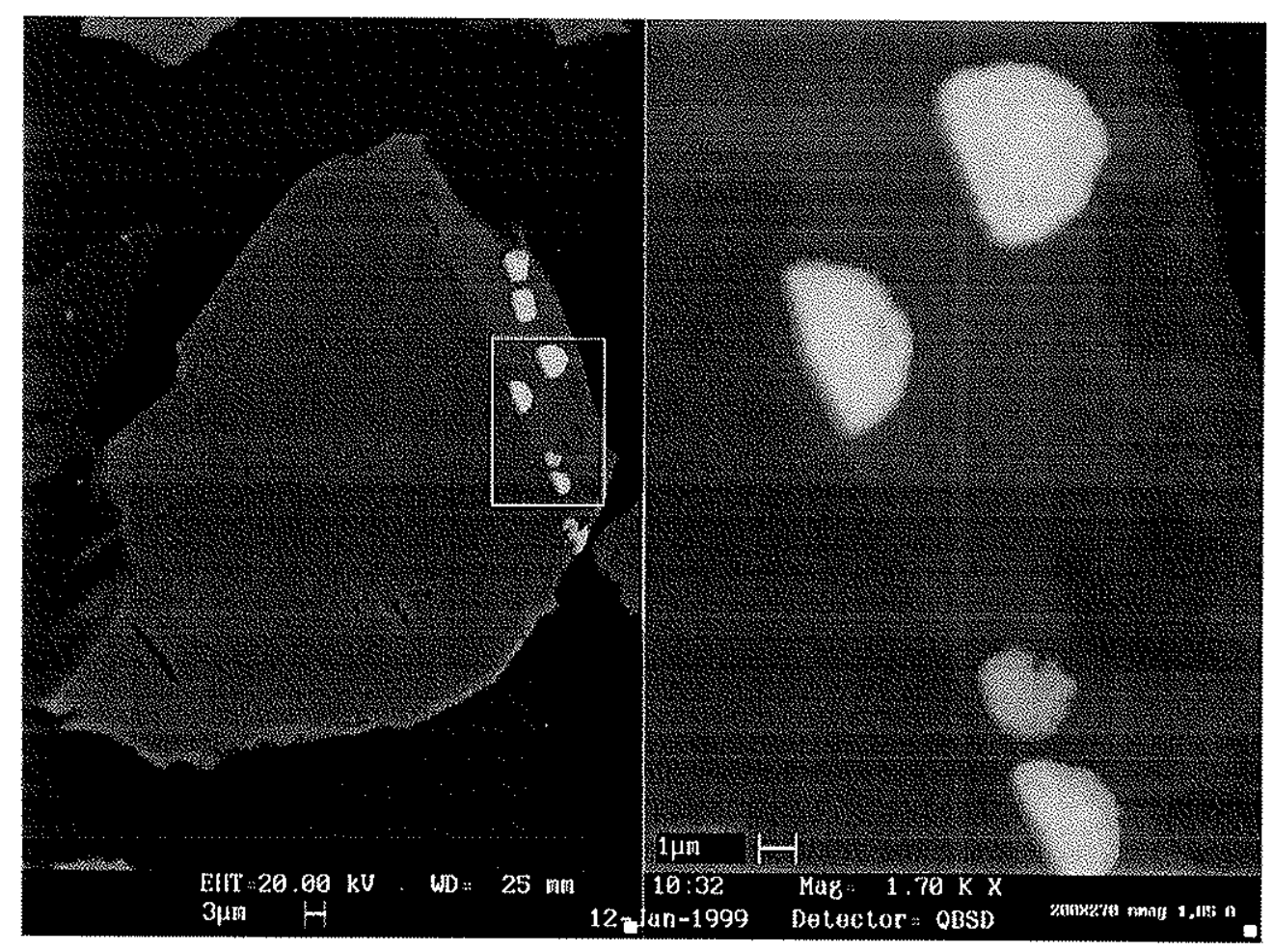

Figura 4.34 - Monazita muito fina no limite entre dois tipos de apatita, com níveis de cinza distintos (MEV/BSD). 


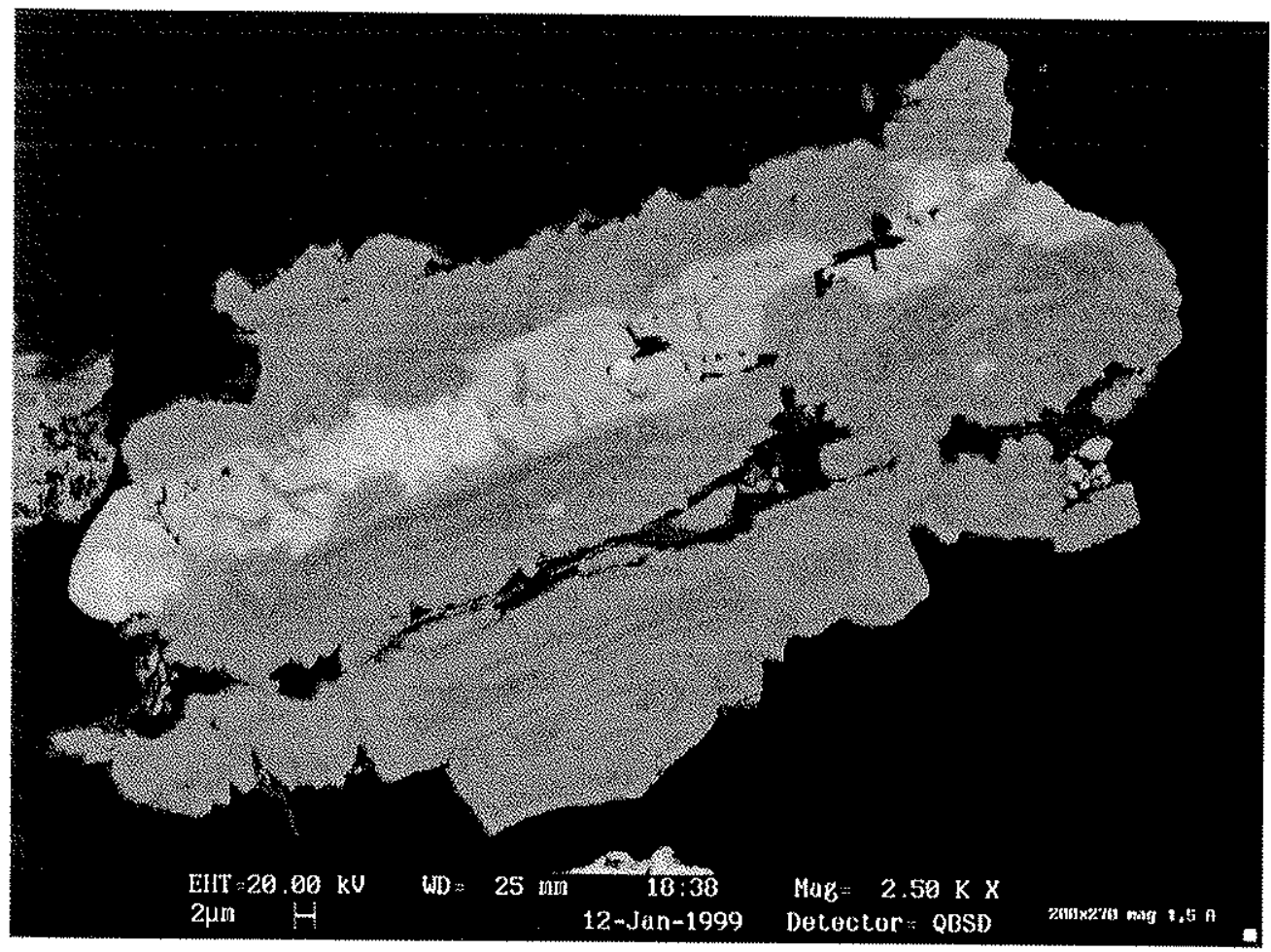

Figura 4.35 - Cristal aparentemente tabular de monazita, bastante corroído, em apatita. (MEV/BSD).

Nas imagens das Figura 4.36 e 4.37 observa-se a associação da monazita com gorceixita. 


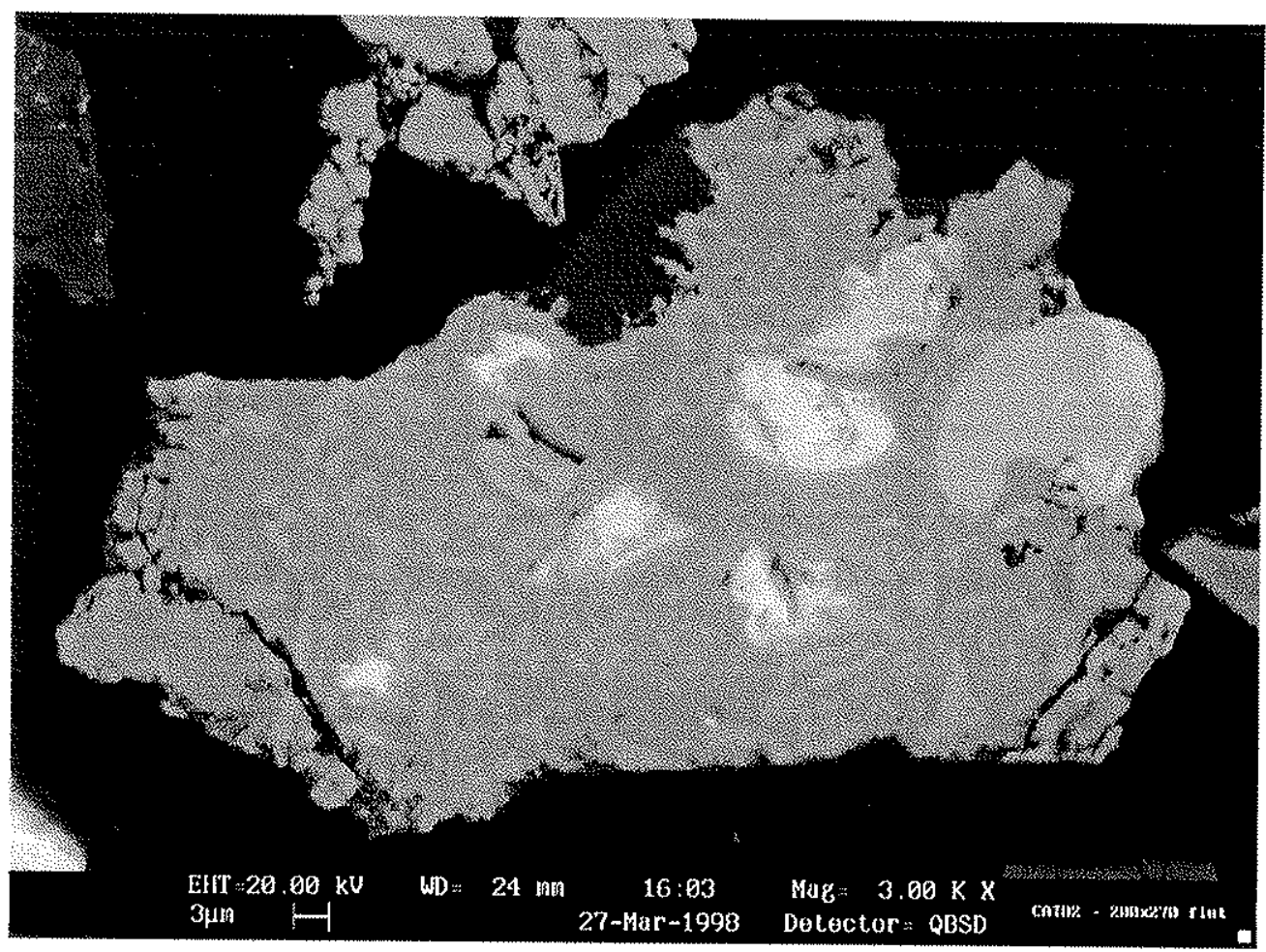

Figura 4.36 - Inclusões de monazita (mais clara) em gorceixita (cinza mais escuro), com inclusões de óxidos/hidróxidos de $\mathrm{Fe}$ (cinza médio), que permeiam a gorceixita. MEV/BSD.

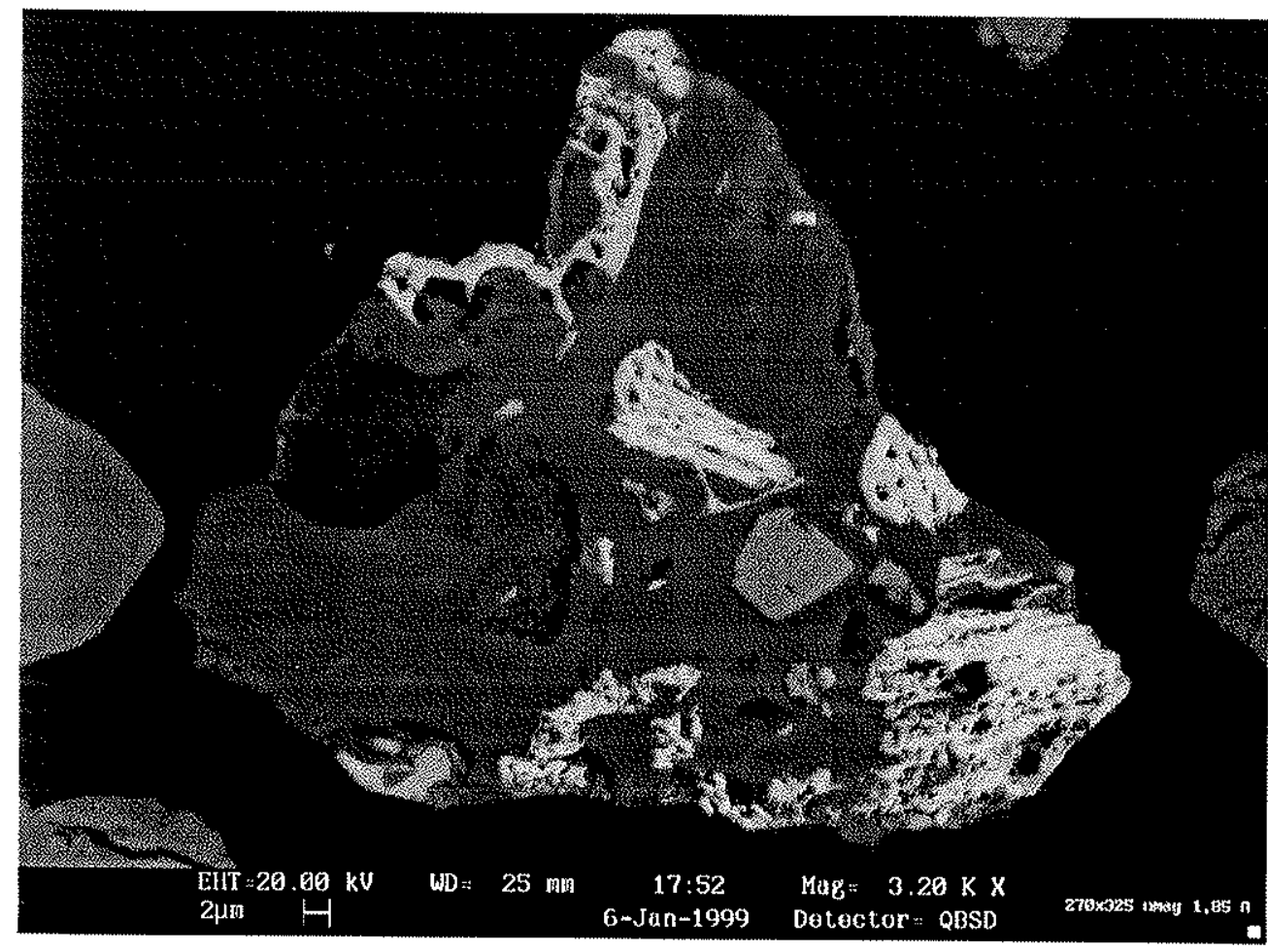

Fïgura 4.37 - Inclusões de monazita maciça e porosa (mais clara) em gorceixita (cinza mais escuro), além de óxido de Fe, provável magnetita (cinza médio). MEV/BSD. 
A outra associação comum da monazita é com os óxidos/hidróxidos de Fe, indistintamente, como pode ser observado na imagem da Figura 4.38. A análise dos restos do provável cristal com formas bem definidas, que deve ter sido arrancado durante o polimento, indica um bariopirocloro com alto teor de $\mathrm{Pb}$. Outro exemplo está na Figura 4.39, com associação de monazita esferoidal a óxidos/hidróxidos de Fe de aspecto esquelético.

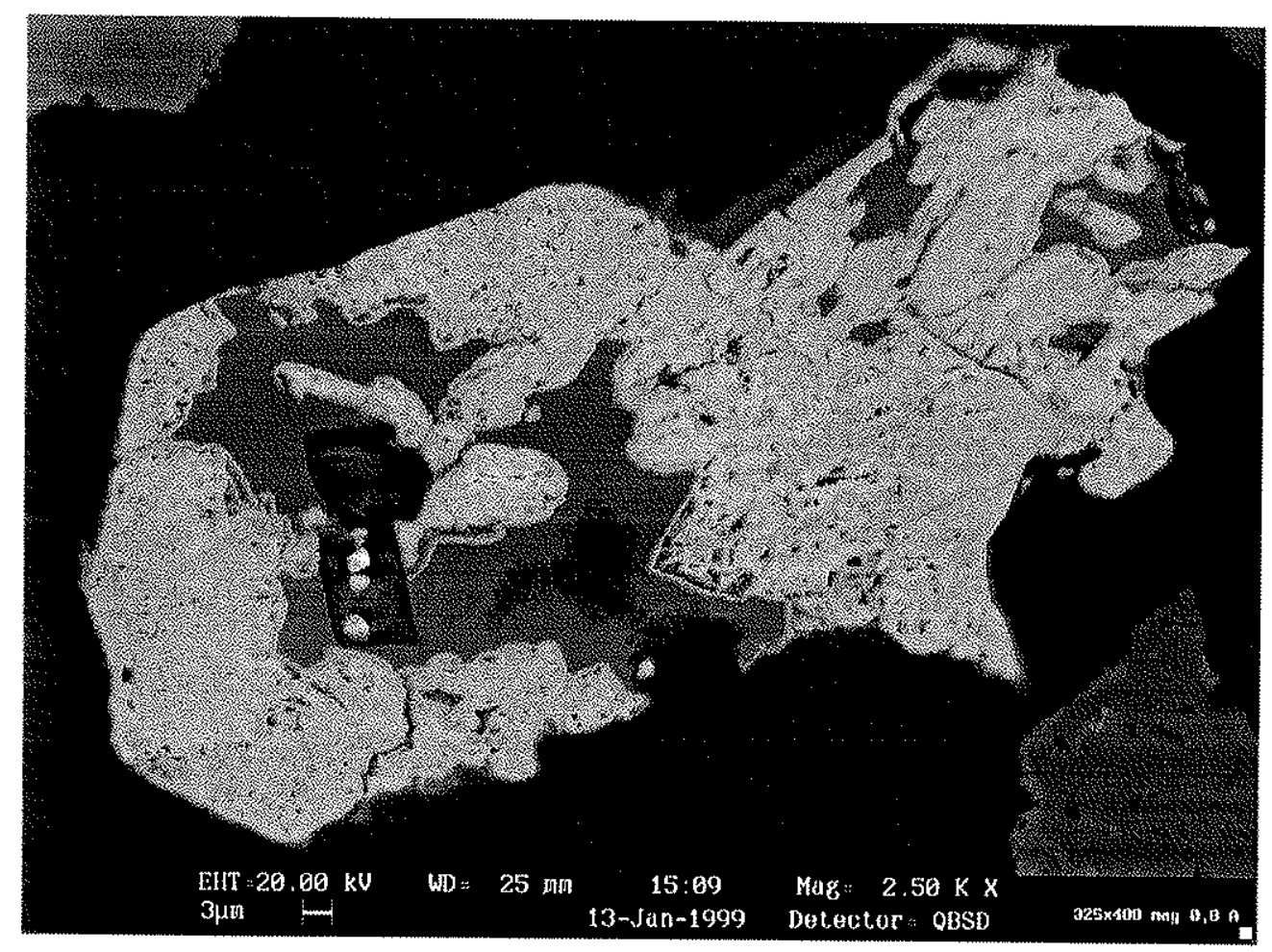

Figura 4.38 - Intercrescimento da monazita porosa com óxidos/hidróxidos de Fe, inclusive com hábito acicular, como pode ser observado na cavidade interna. Restos de cristal possivelmente arrancado durante polimento acusam bariopirocloro com alto $\mathrm{Pb}$. MEV/BSD. 


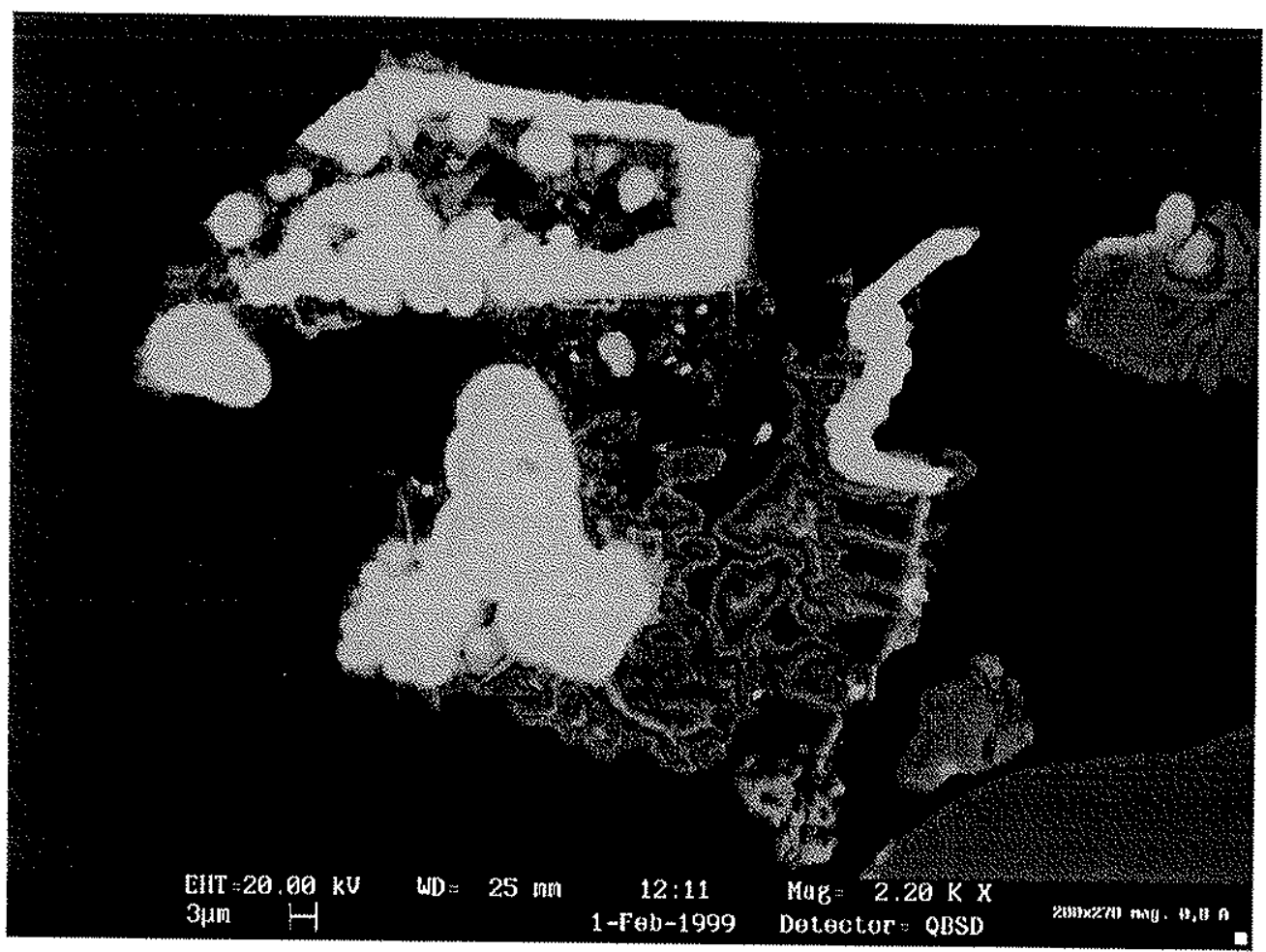

Figura 4.39 - Monazita esferoidal em óxido/hidróxido de Fe de aspecto esquelético. MEV/BSD.

A Figura 4.40 ilustra associação com ilmenita.

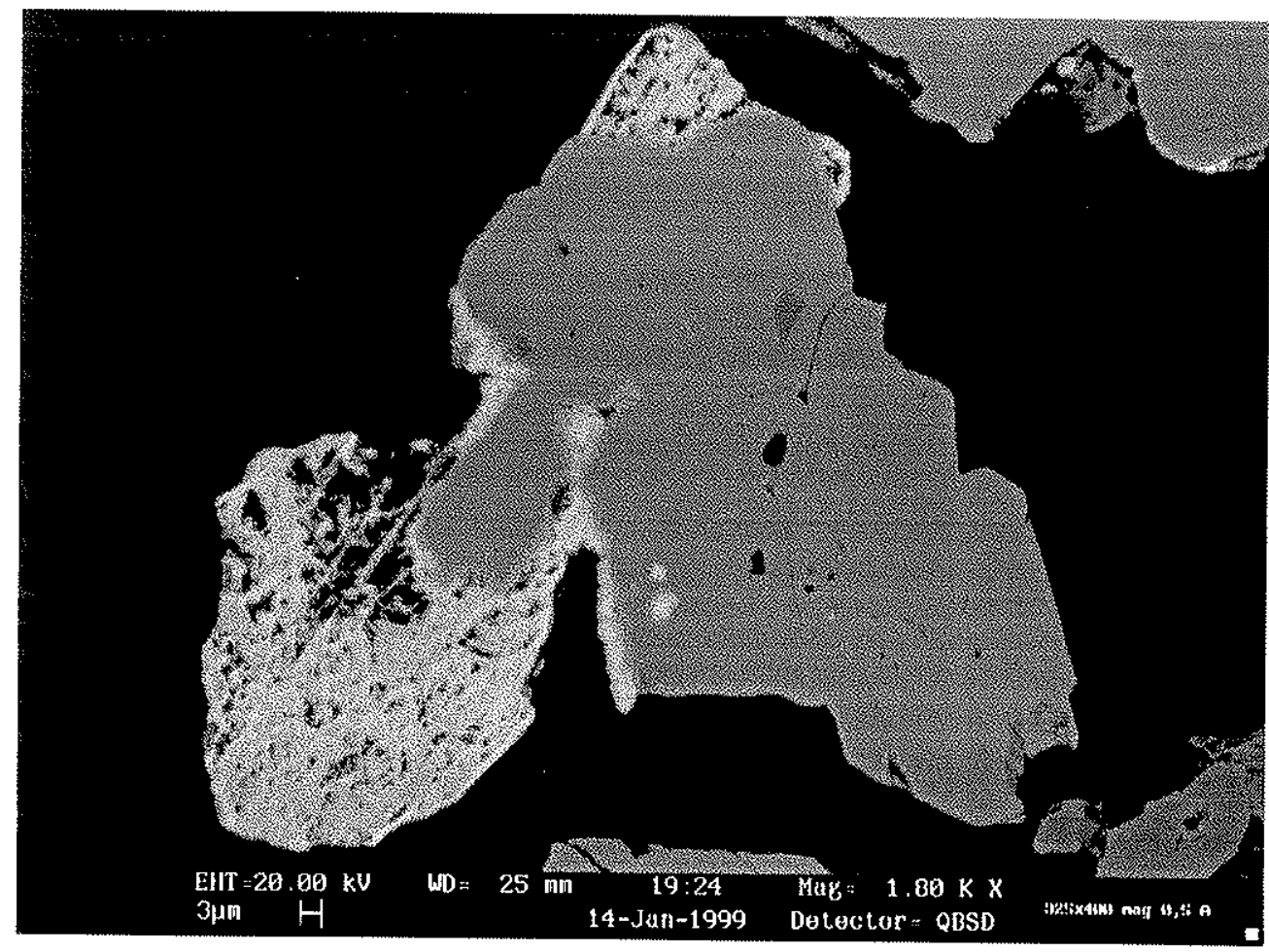

Figura 4.40 - Monazita porosa associada à ilmenita (MEV/BSD). 
Nas monazitas do minério laterítico também ocorrem diferenças consideráveis nos niveis de cinza do mineral. A feição desses níveis de cinza contrastantes, no entanto, difere dos esferóides com níveis concêntricos observados no silexito, e geralmente são bandas ou porções de niveis de cinza diferentes intercrescidos, como pode ser visto nas imagens das Figuras 4.41 e 4.42 , ou monazita de gerações nitidamente diferentes, como na Figura 4.43.

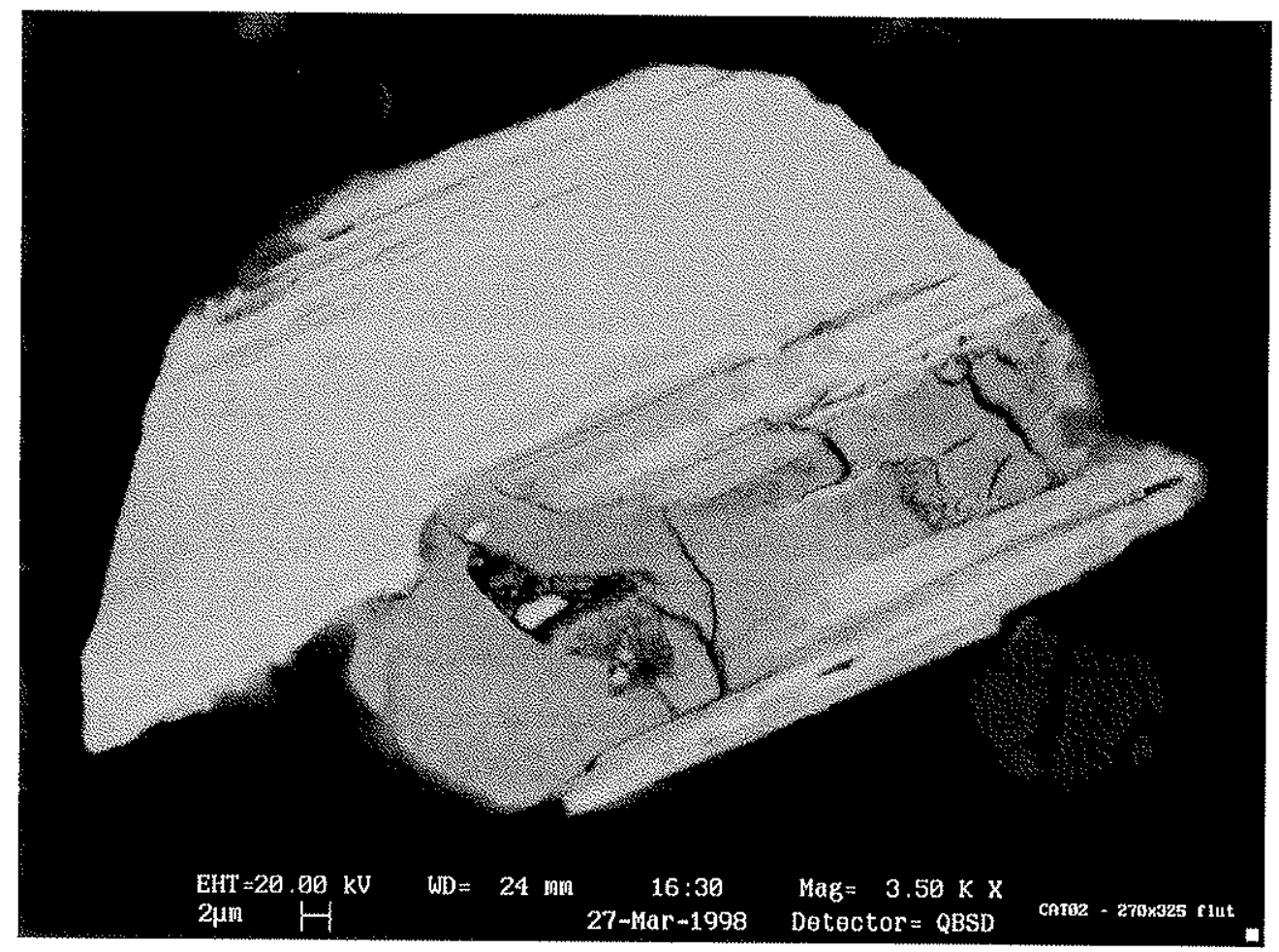

Figura 4.41 - Monazita com niveis de cinza muito discrepantes intercrescidos. MEV/BSD. 


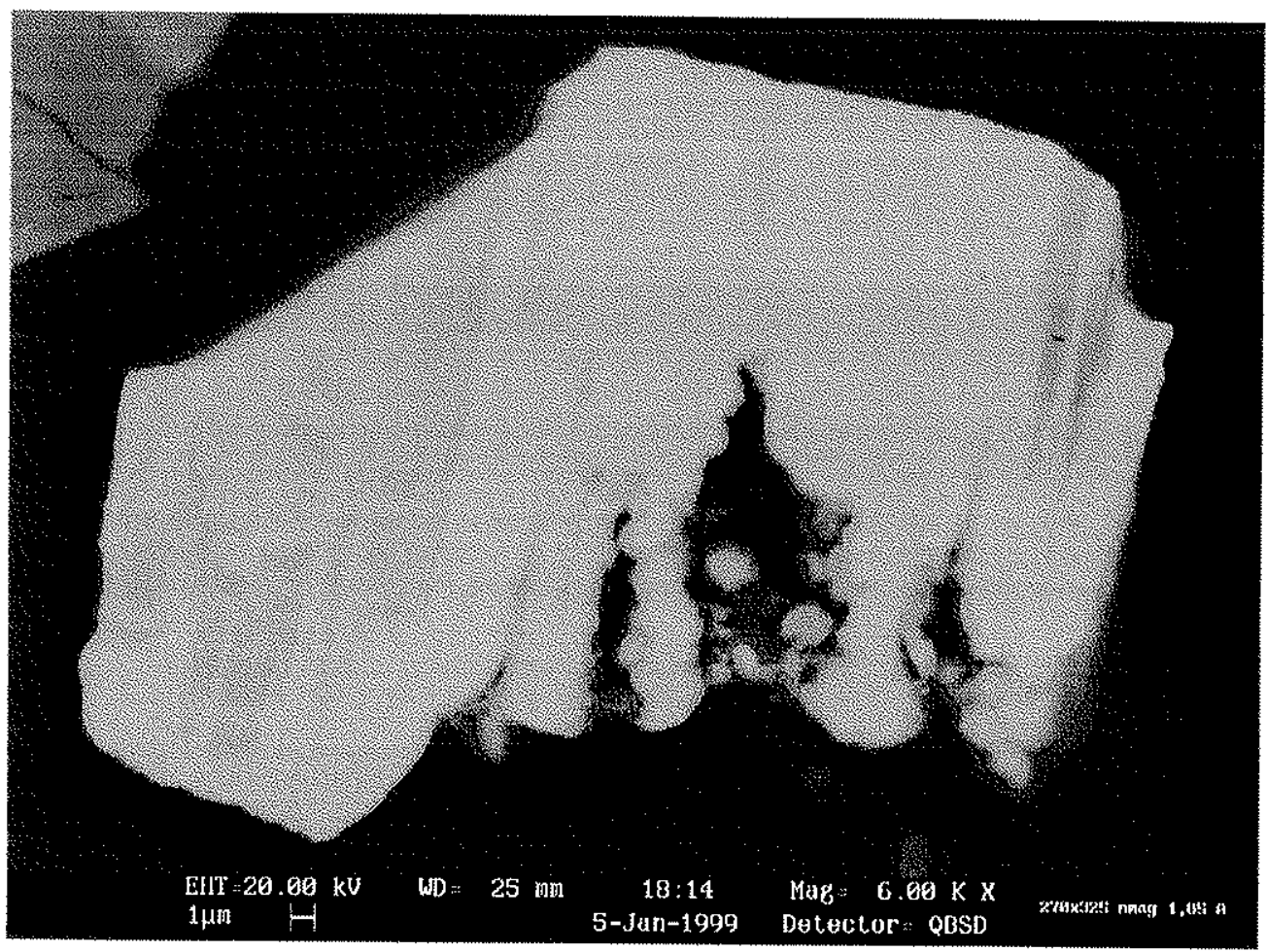

Figura 4.42 - Monazita com niveis de cinza muito discrepantes intercrescidos. MEV/BSD.

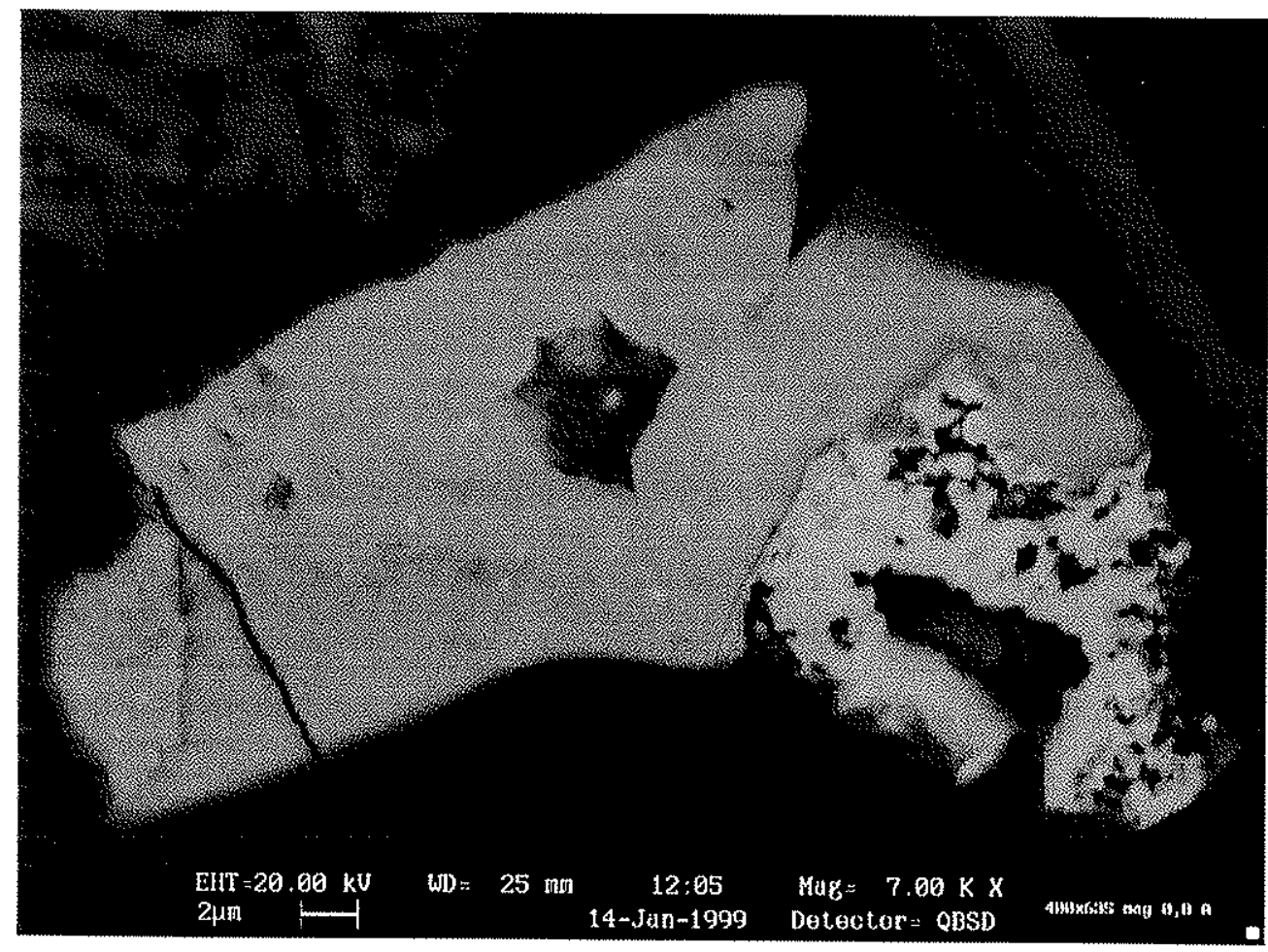

Figura 4.43 - Monazita com níveis de cinza muito discrepantes, possivelmente de diferentes gerações. MEV/BSD. 
Infelizmente os dados de análise por EDS não são conclusivos a respeito da diferença do nivel de cinza. As análises de seis pares de monazita com grandes contrastes, incluindo os das imagens acima, estão na Tabela 4.37.

Tabela 4.37 - Análises comparativas de regiões mais claras e escuras de quatro grãos de monazita (\% por peso), recalculadas para $100 \%$.

\begin{tabular}{lccccccccc}
\hline & $\mathrm{O}$ & $\mathrm{Si}$ & $\mathrm{P}$ & $\mathrm{Ca}$ & $\mathrm{Sr}$ & $\mathrm{La}$ & $\mathrm{Ce}$ & $\mathrm{Nd}$ & $\Sigma \mathrm{ETR}$ \\
\hline Par A, clara & 28,13 & 0,27 & 16,20 & 2,73 & 2,83 & 15,62 & 27,96 & 6,26 & 49,84 \\
Par A, escura & 28,79 & 0,13 & 16,61 & 2,57 & 3,18 & 14,60 & 27,26 & 6,86 & 48,72 \\
Par B, clara & 31,00 & 0,25 & 14,95 & 2,62 & 3,79 & 18,48 & 24,75 & 4,16 & 47,39 \\
Par B, escura & 30,28 & 0,21 & 16,02 & 2,58 & 3,15 & 18,47 & 24,32 & 4,98 & 47,76 \\
Par C, clara & 34,51 & 0,29 & 15,04 & 2,34 & 3,54 & 16,45 & 24,40 & 3,43 & 44,27 \\
Par C, escura & 31,35 & 0,42 & 16,40 & 2,68 & 3,27 & 11,86 & 26,10 & 7,91 & 45,88 \\
Par D, clara & 31,96 & 0,38 & 12,56 & 1,36 & 3,70 & 17,68 & 27,17 & 5,19 & 50,04 \\
Par D, escura & 30,46 & 0,36 & 15,41 & 2,62 & 3,07 & 17,56 & 25,78 & 4,74 & 48,08 \\
Par E, clara & 30,88 & 0,11 & 15,47 & 2,58 & 3,41 & 14,41 & 25,60 & 7,54 & 47,55 \\
Par E, escura & 27,13 & 0,12 & 16,63 & 2,35 & 3,00 & $15,71,26,88$ & 8,18 & 50,77 \\
Par F, clara & 31,24 & 0,12 & 15,45 & 2,21 & 3,50 & 16,24 & 25,82 & 5,43 & 47,48 \\
Par F, escura & 29,97 & 0,14 & 16,11 & 2,18 & 3,11 & 13,96 & 27,28 & $7,24,48,48$ \\
\hline Média claros & 31,29 & 0,23 & 14,95 & 2,31 & 3,46 & 16,48 & 25,95 & 5,34 & \\
Média escuros & $29,66,0,23$ & 16,20 & 2,50 & $3,13,15,36$ & 26,27 & 6,65 & \\
\hline Média & 30,48 & 0,23 & 15,57 & 2,40 & 3,30 & 15,92 & 26,11 & 5,99 & \\
\hline
\end{tabular}

A comparação dos valores das análises não sugere nenhuma razão óbvia para a diferença dos níveis de cinza, apesar de permitir especulações sobre substituições de $\mathrm{Ca}$ por $\mathrm{Sr}$, mais pesado, ou variações na distribuição das terras raras. Essas flutuações, no entanto, são relativamente pequenas, nem sempre sistemáticas, e dificilmente poderiam explicar tal disparidade. Outra possibilidade seria intercrescimento nanométrico com fases mais leves, como pôde ser concluído para o minério silexítico, mas não com quartzo, uma vez que as análises de sílica estão na Tabela 4.37, e não dão margem a essa conclusão. Poder-se-ia especular a respeito de carbonato (por exemplo, calcita), ou mesmo flúor-carbonato do tipo bastnäsita (o flúor foi medido e é sempre baixo, apesar de limitaçöes do EDS para quantificação desse elemento), mas a difração de raios $X$ nunca acusou nenhum dos dois. Da mesma 
forma, a presença simultânea de monazita e rabdofânio não encontra respaldo nas análises de oxigênio acima, nem rabdofânio foi detectado por difração de raios $X$. Rabdofânio e bastnäsita, assim como outros possiveis carreadores de ETR, foram sistematicamente pesquisados nos difratogramas.

A análise dos resultados de EDS, por outro lado, reafirma a composição da monazita do Córrego do Garimpo, em Catalão, uma vez que os resultados são muito similares em ambos os tipos de minério pesquisados até então (comparar com Tabela 4.18 das análise de monazita do minério silexítico), como pode ser verificado na Tabela 4.38, abaixo.

Tabela 4.38 - Análises de EDS de monazita (\% massa), recalculadas para 100\%. Valores médios na última linha, em negrito.

\begin{tabular}{ccccccccc}
\hline $\mathrm{O}$ & $\mathrm{Si}$ & $\mathrm{P}$ & $\mathrm{Ca}$ & $\mathrm{Sr}$ & $\mathrm{La}$ & $\mathrm{Ce}$ & $\mathrm{Nd}$ & $\Sigma \mathrm{ETR}$ \\
\hline 28,1 & 0,3 & 16,2 & 2,7 & 2,8 & 15,6 & 28,0 & 6,3 & 49,8 \\
28,8 & 0,1 & 16,6 & 2,6 & 3,2 & 14,6 & 27,3 & 6,9 & 48,7 \\
29,1 & 0,1 & 15,9 & 2,3 & 3,4 & 12,0 & 27,7 & 9,5 & 49,2 \\
31,0 & 0,2 & 14,9 & 2,6 & 3,8 & 18,5 & 24,8 & 4,2 & 47,4 \\
30,3 & 0,2 & 16,0 & 2,6 & 3,2 & 18,5 & 24,3 & 5,0 & 47,8 \\
31,8 & 0,1 & 15,0 & 2,1 & 3,6 & 19,1 & 24,9 & 3,4 & 47,5 \\
34,5 & 0,3 & 15,0 & 2,3 & 3,5 & 16,4 & 24,4 & 3,4 & 44,3 \\
31,4 & 0,4 & 16,4 & 2,7 & 3,3 & 11,9 & 26,1 & 7,9 & 45,9 \\
32,0 & 0,4 & 12,6 & 1,4 & 3,7 & 17,7 & 27,2 & 5,2 & 50,0 \\
30,5 & 0,4 & 15,4 & 2,6 & 3,1 & 17,6 & 25,8 & 4,7 & 48,1 \\
30,9 & 0,1 & 15,5 & 2,6 & 3,4 & 14,4 & 25,6 & 7,5 & 47,5 \\
27,1 & 0,1 & 16,6 & 2,4 & 3,0 & 15,7 & 26,9 & 8,2 & 50,8 \\
30,4 & 0,1 & 15,7 & 2,2 & 3,5 & 18,4 & 25,3 & 4,4 & 48,1 \\
31,2 & 0,1 & 15,5 & 2,2 & 3,5 & 16,2 & 25,8 & 5,4 & 47,5 \\
30,0 & 0,1 & 16,1 & 2,2 & 3,1 & 14,0 & 27,3 & 7,2 & 48,5 \\
33,9 & 0,1 & 15,8 & 2,4 & 3,2 & 14,7 & 24,1 & 5,8 & 44,6 \\
31,1 & 0,0 & 15,9 & 2,5 & 3,4 & 16,1 & 25,3 & 5,7 & 47,2 \\
30,3 & 0,2 & 16,5 & 2,6 & 2,8 & 12,9 & 27,4 & 7,2 & 47,5 \\
32,7 & 0,1 & 15,1 & 2,6 & 3,7 & 17,7 & 23,0 & 5,0 & 45,7 \\
32,7 & 0,2 & 15,6 & 2,5 & 3,5 & 16,3 & 24,7 & 4,6 & 45,6 \\
29,8 & 0,1 & 15,7 & 2,4 & 3,6 & 18,8 & 26,1 & 3,4 & 48,3 \\
31,4 & 0,1 & 15,2 & 2,6 & 3,5 & 17,8 & 25,4 & 4,0 & 47,2 \\
32,2 & 0,1 & 15,7 & 2,4 & 3,0 & 15,9 & 25,1 & 5,5 & 46,6 \\
\hline 30,9 & $\mathbf{0 , 2}$ & $\mathbf{1 5 , 6}$ & $\mathbf{2 , 4}$ & $\mathbf{3 , 3}$ & $\mathbf{1 6 , 1}$ & $\mathbf{2 5 , 8}$ & $\mathbf{5 , 7}$ & $\mathbf{4 7 , 6}$ \\
\hline
\end{tabular}


O total de ETR nas monazitas é bem constante, variando de 45 a $50 \%$ em massa, a grosso modo. O Sr também é elevado, com média das 23 análises de $3,3 \%, 0$ que, novamente, induz a considerar sua recuperação como subproduto. Em termos de óxidos de terras raras, o total médio é da ordem de $57 \%$, o que é superior às análises de monazita separada manualmente de Imbernon (1993), mas na análise da autora os óxidos de La e Ce praticamente se equivalem $(21,7$ a $22,5 \%$ ), enquanto que nas análises acima o óxido de cério predomina largamente (20,3 a 33,7\%), apesar de existirem análises com distribuição mais balanceada. Além de uma indubitável variação nas composições de monazita, essa diferença também é devida ao recálculo das análises para $100 \%$, e provavelmente a alguma imprecisão maior das análises por EDS. O mesmo poderia ser também inferido para duas análises por ICP de "fosfatos secundários" de Pereira (1995), com teor de ETR total de 40,4 e 52,7\% (que devem ser monazita, a primeira impura, pelos teores de ETR), mas com La representando por volta de metade dos elementos. Os valores estão em perfeita concordância, no entanto, com análises de monazita de diferentes depósitos, brasileiros e de outros países, apresentadas por Lapido Loureiro (1994), inclusive teor e distribuição das terras raras. Não foram encontradas análises de $\mathrm{Sr}$ em monazitas, nas referências consultadas.

Apesar de esferas muito pequenas (da ordem de frações de micrômetros), que se supõe sejam cerianitas, terem sido identificadas em algumas amostras, exclusivamente ao MEV, esse mineral tem uma importância muito menor do que no minério silexítico, como carreador de ETR.

A apatita provavelmente é o segundo carreador mais importante das terras raras no minério laterítico, pela sua abundância e pelo teor. As terras raras ocorrem de duas formas na apatita, como inclusões micro- a submicrométricas de monazita (como visto 
na imagem da Figura 4.34, e na 4.44, abaixo) e como terras raras que se supõe no retículo cristalino da apatita, uma vez que nesse caso não são observáveis fases discretas até o limite da resolução disponivel (por volta de $100 \mathrm{~nm}$ ). A Tabela 4.39 apresenta microanálises por EDS, não recalculadas, de apatitas, incluindo análises dos ETR e de Sr. As diferenças nos niveis de cinza observáveis nas imagens devem-se a variações tanto no teor de Sr quanto de ETR.

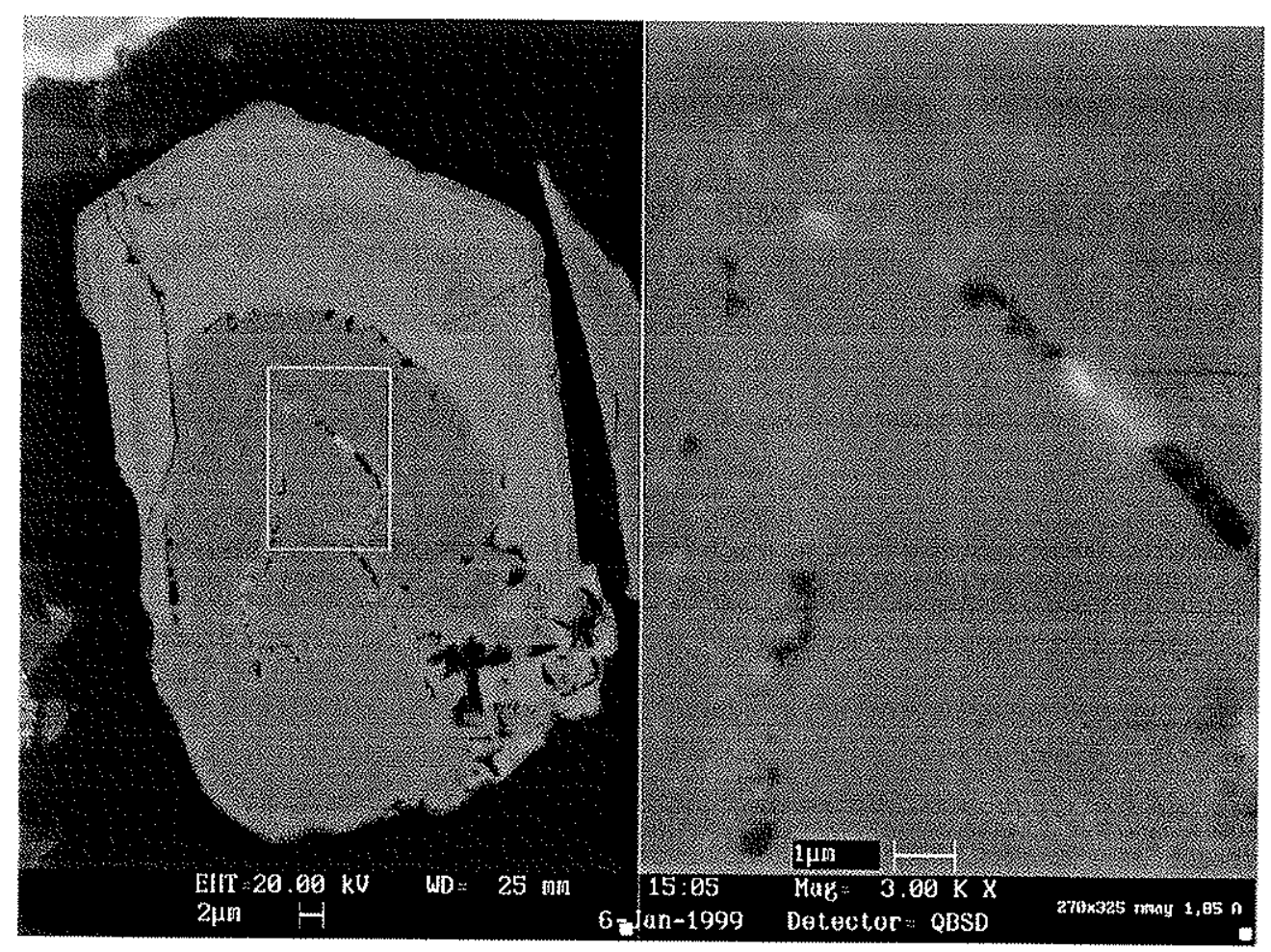

Figura 4.44 - Inclusões de monazita muito fina em apatita com diferentes níveis de cinza. MEV/BSD. 
Tabela 4.39 - Análises de EDS de apatita (\% massa). Valores médios na última linha, em negrito.

\begin{tabular}{ccccccccccc}
\hline $\mathrm{O}$ & $\mathrm{F}$ & $\mathrm{Si}$ & $\mathrm{P}$ & $\mathrm{Ca}$ & $\mathrm{Sr}$ & $\mathrm{La}$ & $\mathrm{Ce}$ & $\mathrm{Nd}$ & Total & $\Sigma \mathrm{ETR}$ \\
\hline 31,16 & 15,04 & 0,15 & 15,48 & 33,65 & 3,50 & $-0,03$ & 0,88 & 0,67 & 100,72 & 1,51 \\
39,14 & 6,81 & 0,22 & 18,82 & 37,23 & 0,80 & 0,15 & $-0,10$ & 0,21 & 103,35 & 0,26 \\
29,48 & 9,12 & 0,03 & 16,86 & 37,12 & 4,48 & 0,48 & 0,60 & $-0,07$ & 98,09 & 1,00 \\
38,33 & 3,49 & 0,49 & 19,49 & 38,55 & 1,35 & 0,71 & 0,88 & 0,18 & 103,47 & 1,77 \\
30,05 & 9,21 & $-0,01$ & 17,12 & 33,79 & 7,97 & 0,03 & 0,27 & 0,35 & 98,82 & 0,64 \\
35,47 & 9,50 & 0,13 & 17,92 & 36,37 & 3,88 & 0,10 & 0,20 & 0,28 & 103,97 & 0,58 \\
32,25 & 8,70 & 0,02 & 17,35 & 34,84 & 6,76 & 0,24 & 1,00 & 0,14 & 101,44 & 1,37 \\
38,80 & 5,79 & 0,18 & 19,66 & 38,90 & 0,97 & 0,39 & 0,52 & 0,33 & 105,64 & 1,24 \\
35,94 & 8,10 & 0,10 & 17,66 & 38,17 & 0,49 & 0,10 & 0,27 & $-0,06$ & 101,70 & 0,30 \\
34,41 & 10,05 & 0,07 & 16,85 & 32,49 & 9,09 & 0,35 & 0,64 & 0,77 & 104,76 & 1,76 \\
32,49 & 11,04 & 0,05 & 16,54 & 32,02 & 7,52 & 0,36 & 1,13 & 0,38 & 101,58 & 1,87 \\
37,61 & 7,44 & 0,39 & 18,78 & 37,32 & 1,39 & 0,39 & 0,59 & 0,21 & 104,10 & 1,19 \\
39,44 & 6,13 & 0,20 & 19,71 & 37,93 & 1,34 & 0,45 & 0,61 & 0,03 & 105,88 & 1,08 \\
31,95 & 8,92 & $-0,07$ & 16,65 & 32,94 & 6,07 & 0,71 & 1,24 & 0,75 & 99,24 & 2,70 \\
37,84 & 4,75 & 0,12 & 19,94 & 38,08 & 1,09 & 0,13 & 0,59 & 0,00 & 102,66 & 0,72 \\
32,23 & 9,26 & 0,07 & 16,83 & 34,00 & 7,06 & 0,18 & 1,03 & 0,54 & 101,54 & 1,75 \\
40,78 & $\mathbf{4} 21$ & 0,03 & 19,17 & 36,28 & 1,05 & $-0,04$ & $-0,08$ & 0,24 & 101,64 & 0,11 \\
$\mathbf{2 8 , 9 6}$ & 8,72 & 0,02 & 15,86 & 33,22 & 6,92 & 0,35 & 0,28 & 0,00 & 94,43 & 0,63 \\
36,25 & 10,23 & 0,02 & 16,92 & 31,72 & 7,82 & 0,52 & 1,23 & 0,60 & 105,35 & 2,35 \\
\hline $\mathbf{3 4 , 8 7}$ & $\mathbf{8 , 2 4}$ & $\mathbf{0 , 1 2}$ & $\mathbf{1 7 , 7 7}$ & $\mathbf{3 5 , 5 1}$ & $\mathbf{4 , 1 9}$ & $\mathbf{0 , 2 9}$ & $\mathbf{0 , 6 2}$ & $\mathbf{0 , 2 9}$ & & $\mathbf{1 , 2 0}$ \\
\hline
\end{tabular}

Essas análises por EDS apresentam um problema crônico (e clássico) de superestimar $F$, e por essa razão apresentam-se os dados não recalculados para óxidos. Por outro lado, o fósforo é ligeiramente inferior ao esperado.

Observa-se que os teores de ETR variam bastante entre os pontos analisados. La varia de 0 a $0,7 \%$, Ce de 0 a $1,24 \%$, e $\mathrm{Nd}$ de 0 a $0,77 \%$, que se reflete na soma desses elementos, variando de 0,11 a $2,7 \%$. A média do teor total de ETR, de 1,2\%, no entanto, é expressiva, considerando-se a sua recuperação como subproduto. Todos esses teores são bem superiores às médias obtidas, por exemplo, por Pereira (1995), Imbernon et al. (1994) e Lenharo (1994), representando aproximadamente o dobro do obtido em todos esses trabalhos. Mas estão dentro da variação de composição apresentada pelos autores. O conteúdo de Sr nessas apatitas é surpreendentemente alto, superando os $9 \%$ em alguma análise, resultando numa média de $4,2 \%$ do elemento, apesar das também grandes flutuações no seu teor. A média obtida no 
minério do Córrego do Garimpo equivale ao quádruplo do obtido por Pereira (1995), e situa-se a quase $1,5 \%$ de SrO acima do valor máximo que mediu. Uma vez que as análises provavelmente estão boas para esses elementos (uma vez que as análises de monazita estão dentro do esperado), conclui-se que tanto ETR quanto Sr estão muito enriquecidos também na apatita na área do Córrego do Garimpo, conclusão bastante lógica para as terras raras, mas até certo ponto surpreendente no caso do Sr. Por outro lado, o teor de Sr também é muito alto na monazita, e foi encontrada estroncianita e dolomita com alto Sr no minério carbonatítico subjacente.

Outros minerais carreadores de terras raras foram detectados no minério laterítico, mas com importância reduzida pelo baixo teor dos elementos e pela pequena quantidade do mineral no minério. A sua descrição mais detalhada se justifica porque potencialmente podem ter interesse como produto ou subproduto num eventual processo que pode ser instalado para o minério, ou porque podem ser mais abundantes e/ou mais interessantes para recuperação em outras porções do maciço alcalino-carbonatítico, principalmente se for considerada a grande variabilidade dos tipos litológicos que se encontram.

O primeiro a ser citado é o pirocloro, que é explotado no maciço pela Mineração Catalão de Goiás SA. Esse mineral (na verdade, são diversos minerais associados) já foi estudado por diversos autores, e com grande detalhamento por Sant'Agostino (1996). O pirocloro mais comum é sempre o bariopirocloro, mas também variedades com alto $\mathrm{Pb}, \mathrm{Ti}, \mathrm{Ce}$ e Ca puderam ser identificadas, e com certa freqüência diversas variedades estão associadas. Na imagem da Figura 4.45 mostra-se um grão composto por pirocloro rico em $\mathrm{Ba}$ (mais escuro) e em $\mathrm{Ti}$, $\mathrm{Ce}$ e $\mathrm{Ca}$ (mais claro), e na Figura 4.46 uma variedade rica em $\mathrm{Ba}$ e $\mathrm{Pb}$. $\mathrm{Na}$ imagem da Figura 4.47, um bariopirocloro com inclusões de ilmenita, gorceixita, quartzo e monazita, esta de hábito esferoidal, no 
detalhe. Algumas análises por EDS, inclusive dos pirocloros ilustrados nas imagens, estão reproduzidas na Tabela 4.40.

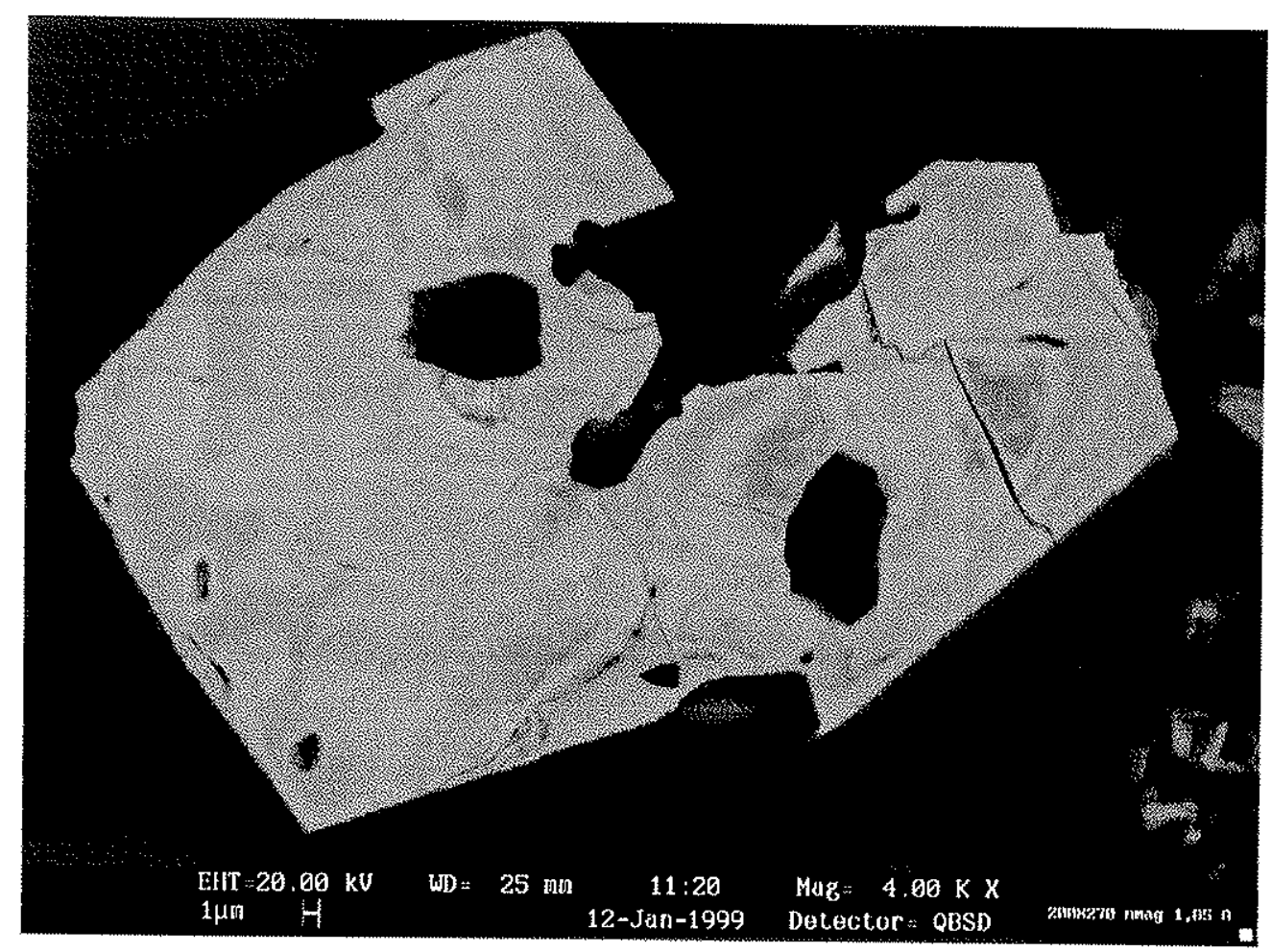

Figura 4.45 - Grão de pirocloro com duas composições, bariopirocloro (mais escuro), e outra variedade rica em Ti, $\mathrm{Ca}$ e Ce (mais clara). MEV/BSD. 


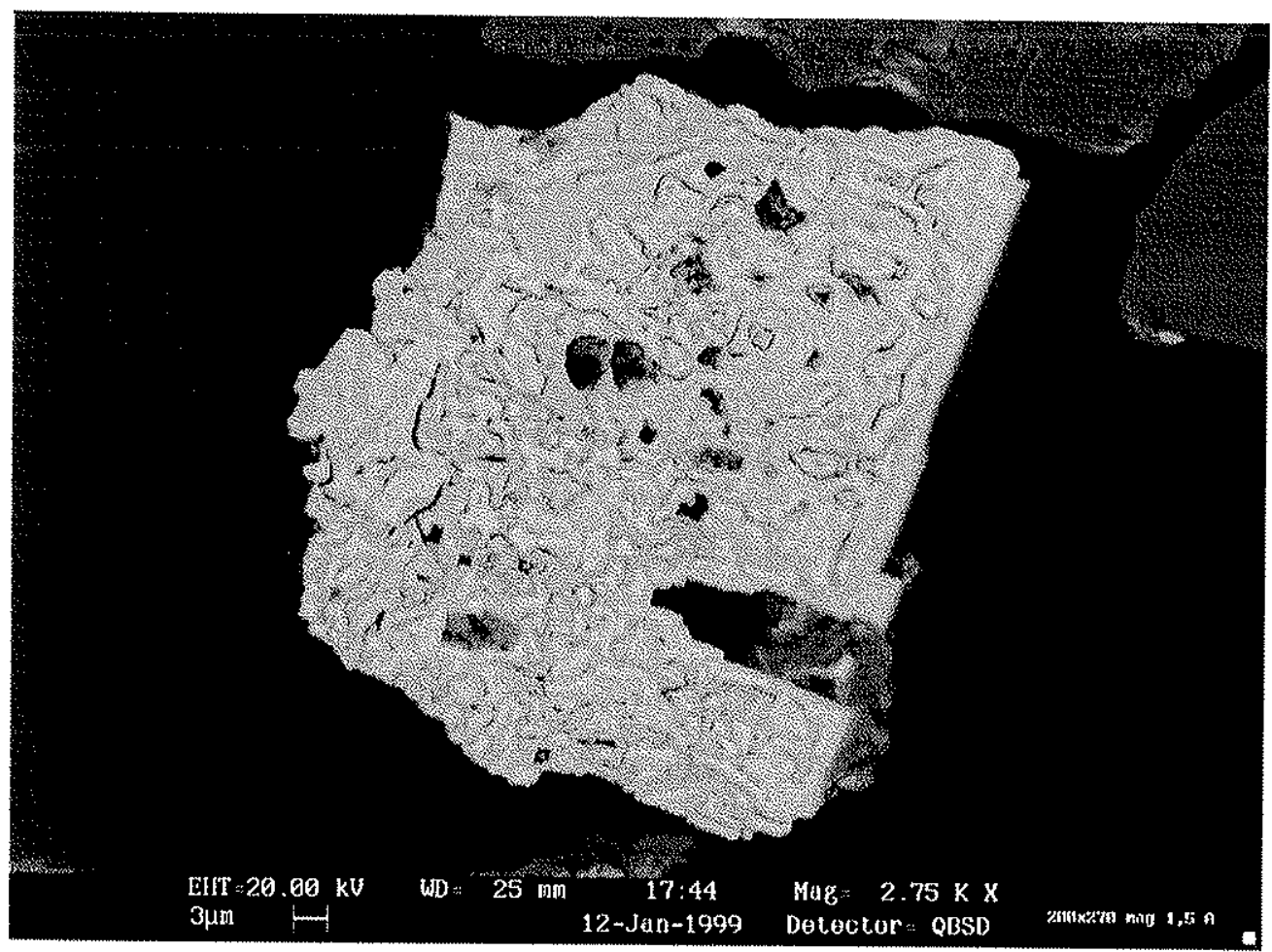

Figura 4.46 - Pirocloro rico em $\mathrm{Pb}$ e $\mathrm{Ba}$. MEV/BSD.

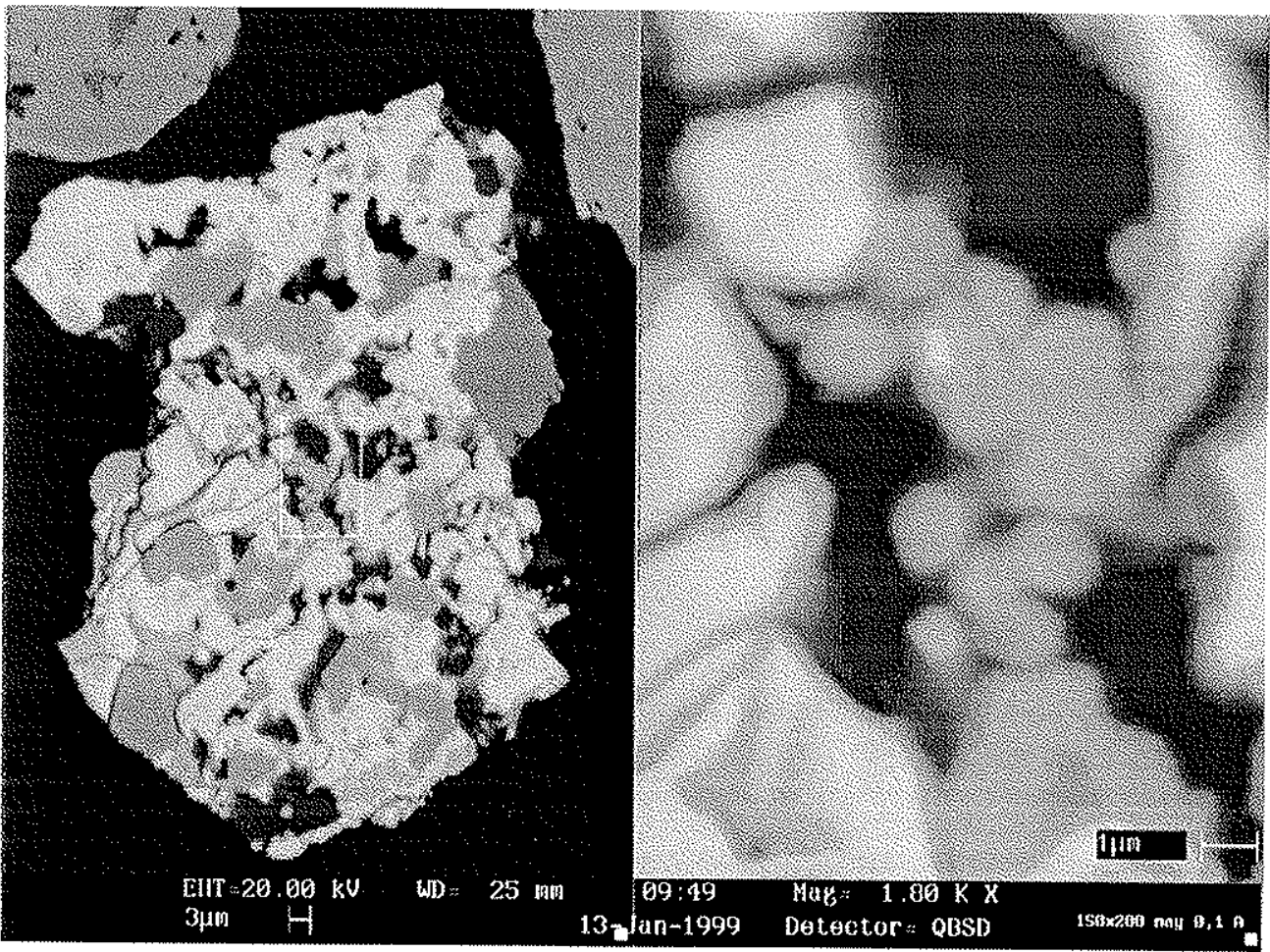

Figura 4.47 - Bariopirocloro (branco) com inclusões grandes de ilmenita, gorceixita (centro, à direita), quartzo (cinza escuro, dispersas), e monazita (no detalhe). MEV/BSD. 
Tabela 4.40 - Composição de alguns pirocloros contendo ETR identificados no minério laterítico (EDS, \% em massa).

\begin{tabular}{|c|c|c|c|c|c|c|c|c|}
\hline & $\begin{array}{l}\text { Fig. } 4.43 \\
\text { escuro }\end{array}$ & $\begin{array}{l}\text { g. } 4.45 \\
\text { claro }\end{array}$ & g. 4. & & & & & \\
\hline $\mathrm{CaO}$ & 0,32 & 8,86 & 0,23 & 0,07 & 1,05 & 0,63 & 0,44 & 8,58 \\
\hline $\mathrm{TiO}_{2}$ & 2,35 & 2,80 & 2,26 & 1,70 & 3,32 & 2,27 & 3,06 & 2,96 \\
\hline $\mathrm{Fe}_{2} \mathrm{O}_{3}$ & 0,60 & 1,10 & 1,38 & 0,82 & 2,65 & 1,71 & 1,16 & 0,37 \\
\hline SrO & 1,09 & 2,86 & 0,29 & 0,08 & 0,00 & 0,00 & 0,00 & 0,71 \\
\hline $\mathrm{Nb}_{2} \mathrm{O}_{5}$ & 65,87 & 71,92 & 59,31 & 59,18 & 49,83 & 49,48 & 59,96 & 63,81 \\
\hline $\mathrm{BaO}$ & 10,62 & 0,73 & 4,09 & 3,47 & 0,00 & 3,62 & 11,04 & 0,07 \\
\hline $\mathrm{CeO}_{2}$ & 4,59 & 3,84 & 3,68 & 1,89 & 4,53 & 1,99 & 2,72 & 3,44 \\
\hline $\mathrm{Nd}_{2} \mathrm{O}_{3}$ & 1,96 & 1,28 & 1,27 & 0,00 & 0,15 & 0,00 & 0,00 & 1,13 \\
\hline $\mathrm{Ta}_{2} \mathrm{O}_{5}$ & 0,00 & 0,00 & 0,00 & 0,00 & 1,50 & 0,00 & 3,63 & 1,92 \\
\hline $\mathrm{PbO}$ & 6,61 & 0,00 & 23,22 & 34,09 & 32,45 & 29,15 & 11,85 & 0,00 \\
\hline $\mathrm{ThO}_{2}$ & 0,00 & 0,00 & 0,29 & 0,00 & 0,00 & 0,54 & 0,26 & 1,74 \\
\hline $\mathrm{UO}_{2}$ & 0,14 & 0,04 & 1,17 & 0,51 & 1,46 & 1,18 & 0,00 & 0,00 \\
\hline Total & 94,15 & 93,44 & 97,19 & 101,80 & 96,94 & 90,57 & 94,12 & 84,73 \\
\hline$\Sigma$ OTR & 6,55 & 5,12 & 4,95 & 1,89 & 4,67 & 1,99 & 2,72 & 4,57 \\
\hline
\end{tabular}

Não há uma correlação óbvia do teor de ETR no pirocloro com a sua composição de elementos maiores, e nem os dados a permitem, uma vez que o objetivo do trabalho são as terras raras, e as análises foram executadas sempre que os ETR puderam ser identificados no mineral. Observa-se, no entanto, que o teor pode ser considerável, acima de $6 \%$ em óxidos. As análises estão em boa concordância com o apresentado, por exemplo, por Sant'Agostino (1996), inclusive dados seus oriundos da bibliografia, e com dados de Pereira (1995).

Apesar do pirocloro de Catalăo I ser explotado comercialmente pela Mineração Catalão de Goiás, as terras raras não são recuperadas, estando encapsuladas no resíduo do tratamento aluminotérmico. Esse rejeito não é processado, apesar de composto basicamente por metais de valor comercial, pelo seu alto teor em Th, esse sem mercado e de manuseio progressivamente mais restrito e complicado (e caro) à medida que a sua concentração cresce.

Outro carreador ainda não está devidamente identificado. Trata-se de um óxido de $\mathrm{Zr}$, Ti e $\mathrm{Ca}$ que foi identificado com relativa facilidade em diversas frações do 
minério. Depois de uma série de análises ao MEV, descobriu-se que existia uma dualidade, tendo-se, na verdade dois óxidos de $\mathrm{Zr}, \mathrm{Ca}, \mathrm{e} \mathrm{Ti}$ diferentes, que com freqüência coexistem. A partir dos dados de EDS foram facilmente separadas as duas fases, uma vez que a composição varia muito, a começar pelo teor de zircônio, 25-30\% em uma e por volta de $50 \%$ na outra. A identificação precisa de quais são os minerais detectados, no entanto, é mais difícil, inclusive por difração de raios X. Um pico em aproximadamente $2,92 \AA$, presente em alguns espectros de material afundado não magnético a 1,85 A e que não é atribuivel a nenhuma das outras fases identificadas por difração, foi tentativamente associado a essas fases. Com a composição obtida pelas análises de EDS, o mineral que permite melhor fitting com o espectro é a zirconolita, apesar da respectiva ficha (ICDD 1996) fornecer uma análise de $\mathrm{Nb}_{2} \mathrm{O}_{5}$ acima de $15 \%$, e as fases identificadas apresentarem uma média de aproximadamente $3,3 \%$ do óxido (podendo chegar a 10\%). Foi então assumido, com as devidas ressalvas quanto à imprecisão da identificação, que a fase que contém por volta de 25 a $30 \%$ de Zr é a zirconolita. A segunda fase, que contém por volta de $15 \%$ de $\mathrm{Zr}$, pode ser uma calzirtita ou uma tazheranita. Considerando-se, no entanto, que não há informações cristalográficas sobre essa fase (assumindo-se que o pico a 2,92 $\AA$ comentado seja devido à zirconolita), que a tazheranita, segundo a sua ficha (22-540, ICDD 1996), é uma estrutura defeituosa da calzirtita, e que esse mineral já foi descrito antes (por exemplo, Sant'Agostino 1996), assumimos que essa fase é uma calzirtita, com as mesmas reservas quanto à precisão de sua identificação da zirconolita.

As imagens das Figuras 4.48 e 4.49 mostram a coexistência de zirconolita e calzirtita, bastante comum. No caso da imagem da Figura 4.49, ocorre ainda uma inclusão mais clara, com teor considerável de Th, cuja análise está na Tabela 4.41. 
Pode ser, inclusive, uma monazita, excepcionalmente com alto Th e Sr também muito elevado.

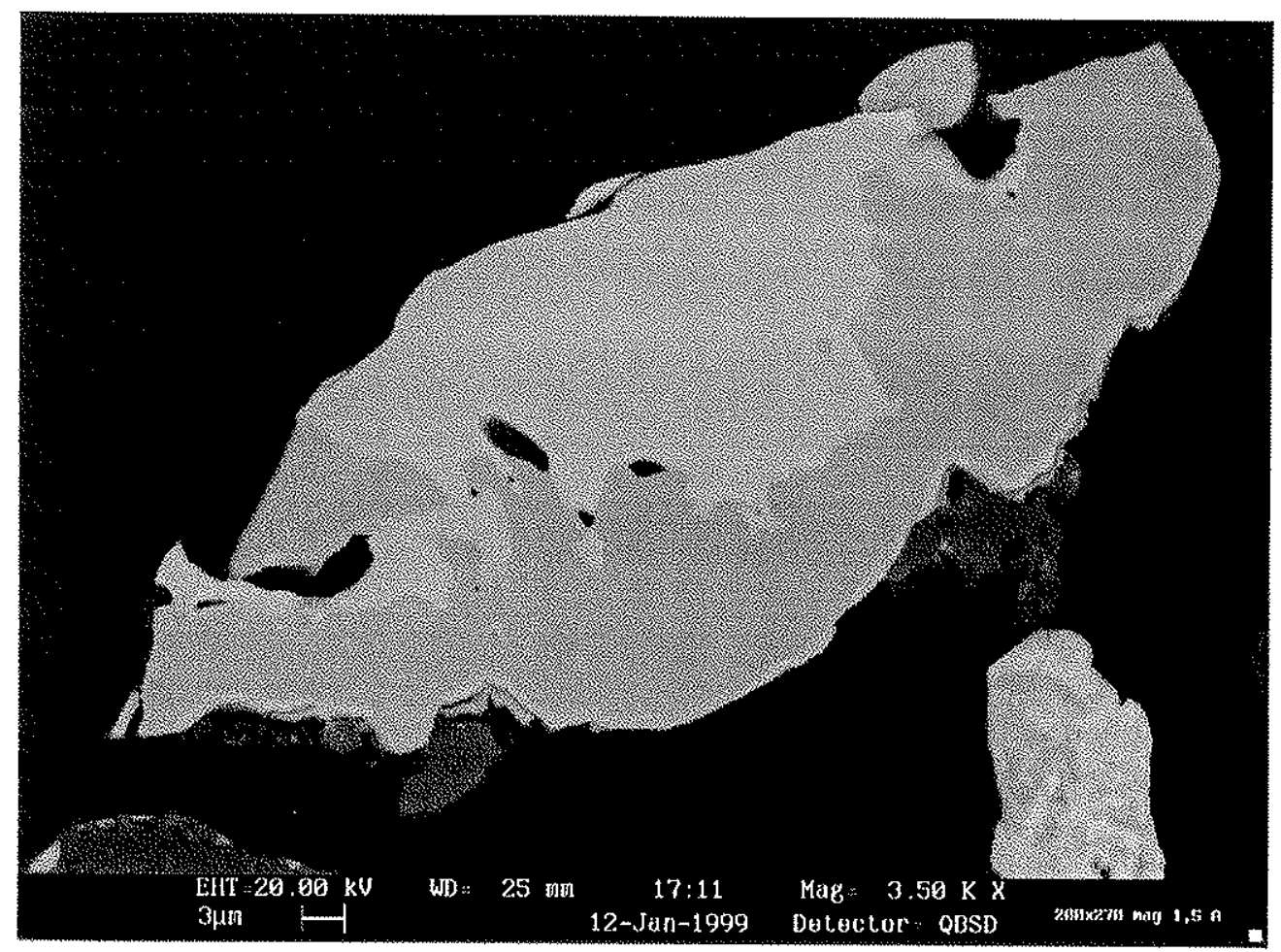

Figura 4.48 - Intercrescimento de zirconolita (mais escura) e calzirtita (mais clara). MEV/BSD. 


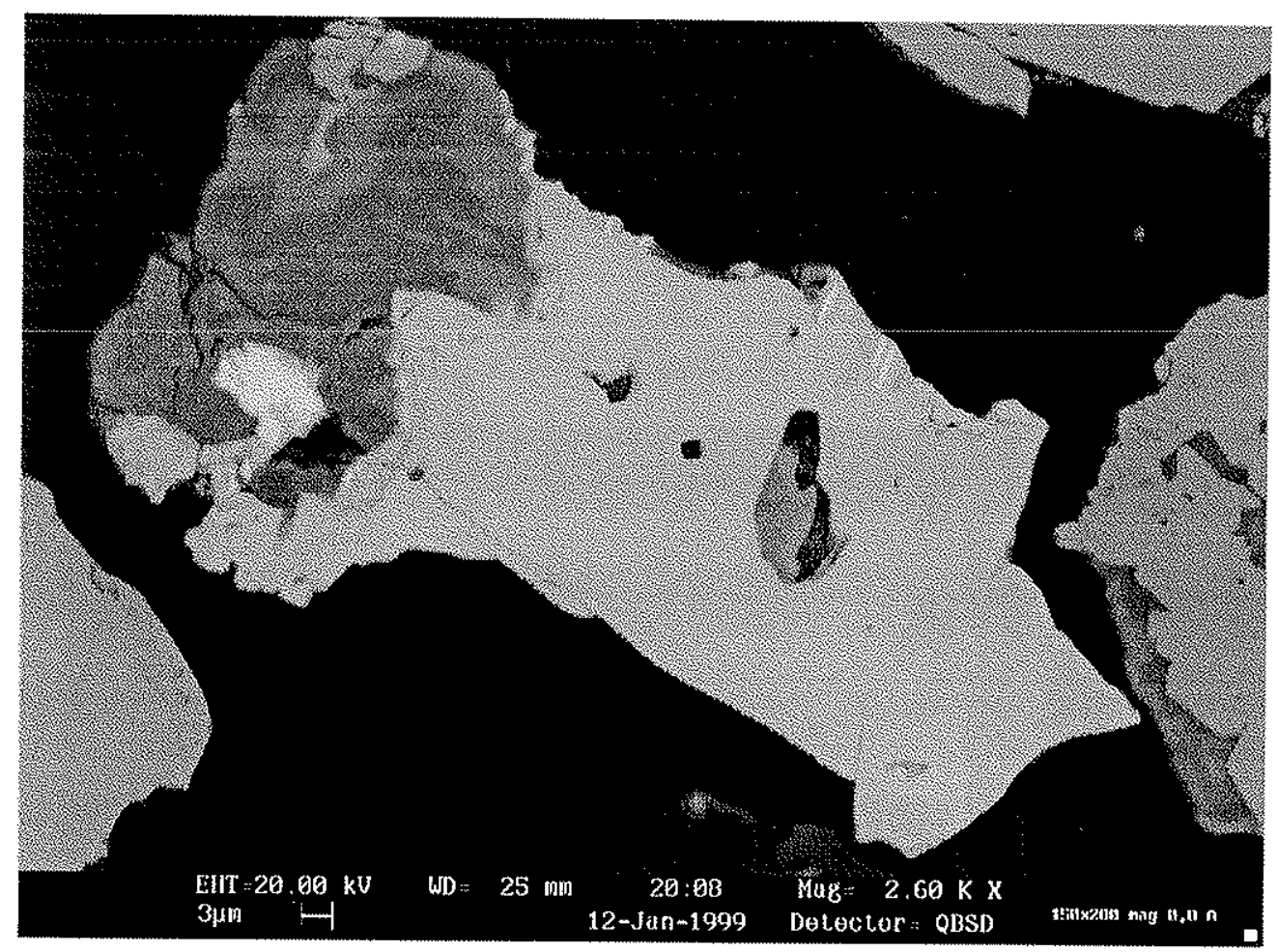

Figura 4.49 - Grão com calzirtita (cinza intermediário claro) predominante, com zirconolita (cinza médio mais escuro), e gorceixita (cinza escuro, parte superior), por sua vez contendo uma inclusão de mineral com alto Th (branco), e ilmenita (inclusão mais escura na carzirtita). MEV/BSD.

Tabela 4.41 - Composição da inclusão rica em Th, mais clara, da imagem da Figura 4.49 (EDS, \% em massa, recalculado para $100 \%$ ).

\begin{tabular}{lr}
$\mathrm{P}_{2} \mathrm{O}_{5}$ & 29,20 \\
$\mathrm{CaO}$ & 7,99 \\
$\mathrm{TiO}_{2}$ & 0,71 \\
$\mathrm{Fe}_{2} \mathrm{O}_{3}$ & 0,80 \\
$\mathrm{SrO}$ & 11,31 \\
$\mathrm{BaO}$ & 2,76 \\
$\mathrm{La}_{2} \mathrm{O}_{3}$ & 1,69 \\
$\mathrm{CeO}_{2}$ & 17,29 \\
$\mathrm{Nd}_{2} \mathrm{O}_{3}$ & 17,21 \\
$\mathrm{ThO}_{2}$ & 11,04 \\
\hline
\end{tabular}

A zirconolita apresenta teores mais elevados de terras raras, apesar de variáveis. A Tabela 4.42 apresenta análises por EDS de diversos grãos de zirconolita. 
Tabela 4.42 - Composição de grãos de zirconolita (EDS, \% em massa). Última coluna, em negrito, apresenta a média das análises.

\begin{tabular}{ccccccccccccc}
\hline $\mathrm{MgO}$ & 0,38 & 0,16 & 0,46 & 0,00 & 0,00 & 0,00 & 0,00 & 0,00 & 0,00 & 0,00 & $\mathbf{0 , 1 0}$ \\
$\mathrm{CaO}$ & 9,33 & 9,26 & 10,64 & 13,40 & 10,21 & 11,31 & 12,90 & 11,84 & 13,34 & 13,23 & $\mathbf{1 1 , 5 5}$ \\
$\mathrm{Sc}_{2} \mathrm{O}_{3}$ & 0,00 & 0,00 & 0,00 & 0,06 & 0,25 & 0,12 & 0,24 & 0,00 & 0,00 & 0,00 & $\mathbf{0 , 0 7}$ \\
$\mathrm{TiO}_{2}$ & 27,12 & 27,49 & 26,23 & 31,85 & 31,73 & 34,70 & 35,89 & 34,89 & 37,14 & 36,60 & $\mathbf{3 2 , 3 6}$ \\
$\mathrm{Fe}_{2} \mathrm{O}_{3}$ & 6,91 & 7,27 & 7,16 & 6,18 & 6,97 & 6,19 & 5,37 & 5,97 & 4,87 & 4,53 & $\mathbf{6 , 1 4}$ \\
$\mathrm{ZrO}_{2}$ & 33,02 & 32,34 & 33,57 & 35,14 & 36,42 & 36,51 & 37,27 & 36,97 & 36,90 & 38,61 & $\mathbf{3 5 , 6 7}$ \\
$\mathrm{Nb}_{2} \mathrm{O}_{5}$ & 2,64 & 4,73 & 9,83 & 6,84 & 3,55 & 2,89 & 0,00 & 3,55 & 2,11 & 3,03 & $\mathbf{3 , 9 2}$ \\
$\mathrm{CeO}_{2}$ & 5,96 & 4,22 & 2,15 & 1,50 & 4,25 & 2,66 & 2,08 & 2,38 & 1,46 & 2,04 & $\mathbf{2 , 8 7}$ \\
$\mathrm{Nd}_{2} \mathrm{O}_{3}$ & 3,33 & 2,14 & 1,85 & 1,59 & 2,82 & 3,10 & 2,17 & 1,97 & 1,88 & 1,08 & $\mathbf{2 , 1 9}$ \\
$\mathrm{HfO}_{2}$ & 0,00 & 0,00 & 0,00 & 0,65 & 1,00 & 0,74 & 0,79 & 0,29 & 0,00 & 0,00 & $\mathbf{0 , 3 5}$ \\
$\mathrm{ThO}_{2}$ & 1,11 & 0,64 & 1,81 & 0,00 & 0,00 & 0,00 & 0,00 & 0,00 & 0,00 & 0,00 & $\mathbf{0 , 3 6}$ \\
$\mathrm{UO}_{2}$ & 0,00 & 0,00 & 0,00 & 0,88 & 0,00 & 0,00 & 0,00 & 0,00 & 0,00 & 0,00 & $\mathbf{0 , 0 9}$ \\
\hline ¿ OTR & 9,30 & 6,36 & 4,00 & 3,09 & 7,07 & 5,76 & 4,25 & 4,35 & 3,34 & 3,13 & $\mathbf{5 , 0 6}$ \\
$\mathrm{Total}_{2}$ & 89,82 & 88,25 & 93,70 & 98,10 & 97,20 & 98,21 & 96,70 & 97,86 & 97,71 & 99,12 & $\mathbf{9 5 , 6 7}$ \\
\hline
\end{tabular}

Nos teores de OTR variando de 3 a quase 10\%, estão incluidos também os resultados das análises de Sc. Esse elemento está presente em pequenas quantidades (até $0,25 \%$ do seu óxido), mas tem um altíssimo valor de mercado, agregando bastante valor a um eventual concentrado. Por outro lado, a presença constante de Th, embora em pequenas quantidades, representa sempre um problema. U foi encontrado em apenas uma análise. É interessante notar que o La nunca foi identificado nas análises de zirconolita.

Mais uma vez, esses dados estão em boa concordância com as análises apresentadas por Pereira (1995), mas algumas diferenças são notáveis, O Th medido nesse trabalho é sistematicamente muito inferior ao medido por Pereira (1995) (desconsiderando-se três das suas análises com alto Th e baixo $\mathrm{Ca}$, provavelmente porque se trata de outra fase), geralmente superior a $3 \%$, enquanto as análises nesse trabalho apontam para uma variação de 0 a $1,8 \%$. Os OTR também são mais abundantes nas medidas de Pereira (1995), geralmente acima de $8 \%$ (excluindo-se as três amostras que não são de zirconolita), contra uma média de aproximadamente 5\% desse trabalho. As análises também apresentaram discrepâncias com aquelas 
apresentadas por Sant'Agostino (1996). Embora o teor médio de $\mathrm{Nb}$ mais elevado sugira comparação com a sua niobozirconolita, a análise desse mineral apresentada pela autora tem baixo teor de $\mathrm{CaO}$ e de cátions em geral. Talvez um eventual estado de preservação melhor da zirconolita da região do Córrego do Garimpo tenha permitido uma análise mais segura do mineral, pois, à exceção do teor de $\mathrm{Nb}$, a composição se aproxima muito do estabelecido na sua ficha de DRX (ICDD 1996). Dessa forma optoum se por não chamar a fase identificada de niobozirconolita, uma vez que a zirconolita fichada tem teor de $\mathrm{Nb}$ muito maior do que o encontrado aqui.

A associação da zirconolita à gorceixita é comum. Pode ser observada nas imagens das Figuras 4.50 e 4.51 , na primeira como pequena inclusão de zirconolita em gorceixita (e ilmenita), e na segunda como intercrescimento das fases, contendo ainda restos de baddeleyita e um pequeno cristal de bariopirocloro.

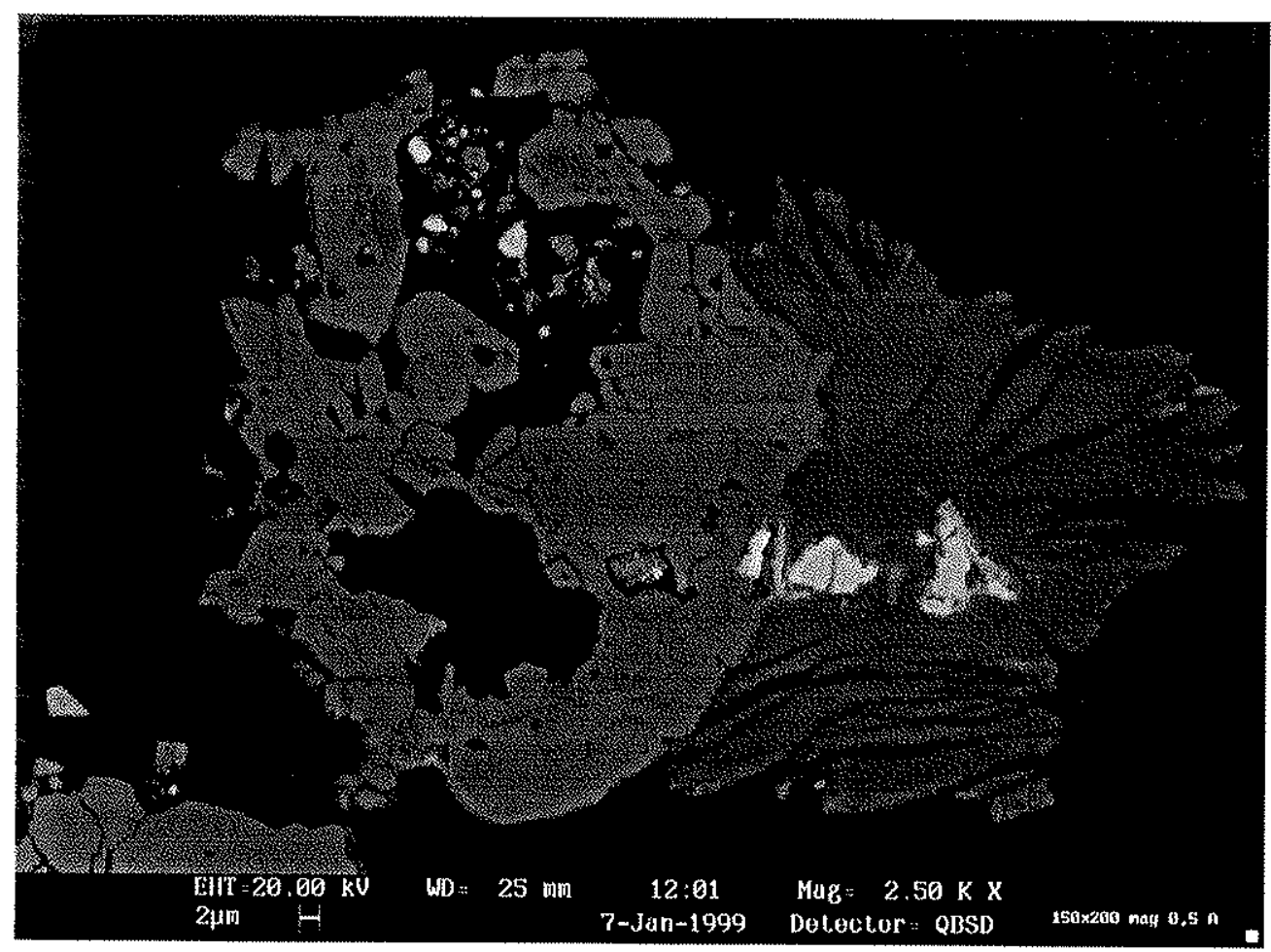

Figura 4.50 - Pequena inclusão de zirconolita (mais clara) em gorceixita (mais escura) e em ilmenita (cinza médio). MEV/BSD. 


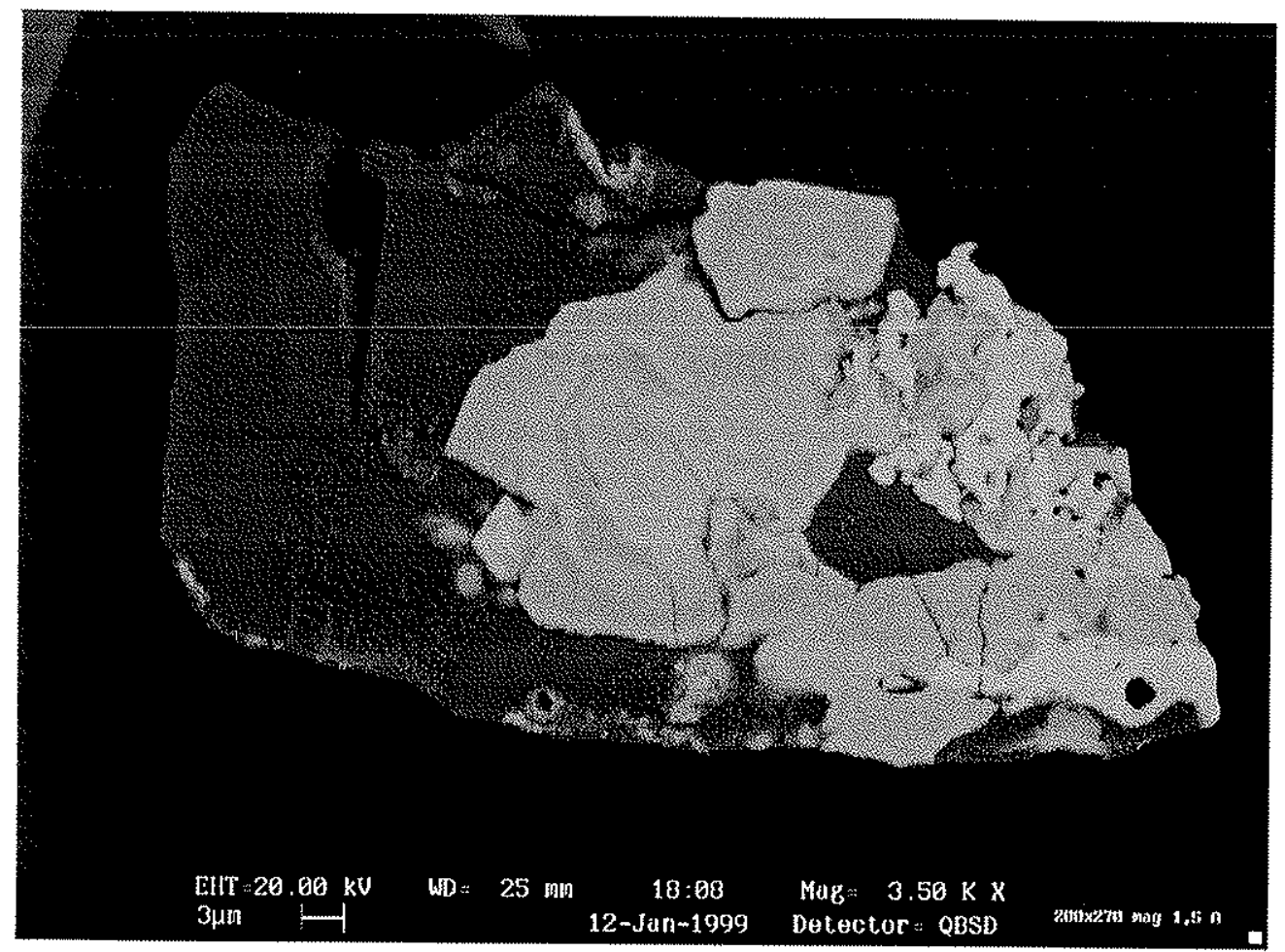

Figura 4.51 - Intercrescimento de zirconolita (cinza médio) e gorceixita (mais escura), contendo ainda restos de baddeleyita corroída (cinza bem claro, à direita) e um cristal pequeno de bariopirocloro (claro, entre zirconolita e gorceixita, centro à esquerda). MEV/BSD.

É comum também que a zirconolita se apresente em cristais zonados; apesar dos domínios mais escuros terem dimensões no limite da área analisada pelo detector de EDS, aparentemente o teor de $\mathrm{Zr}$ maior ou menor condiciona o nivel de cinza, respectivamente, mais claro e mais escuro. Na imagem da Figura 4.52 observa-se um cristal zonado de zirconolita, novamente associado a gorceixita e bariopirocloro, e na imagem da Figura 4.53 pedaços de um cristal zonado de zirconolita associado a apatita e quartzo. 


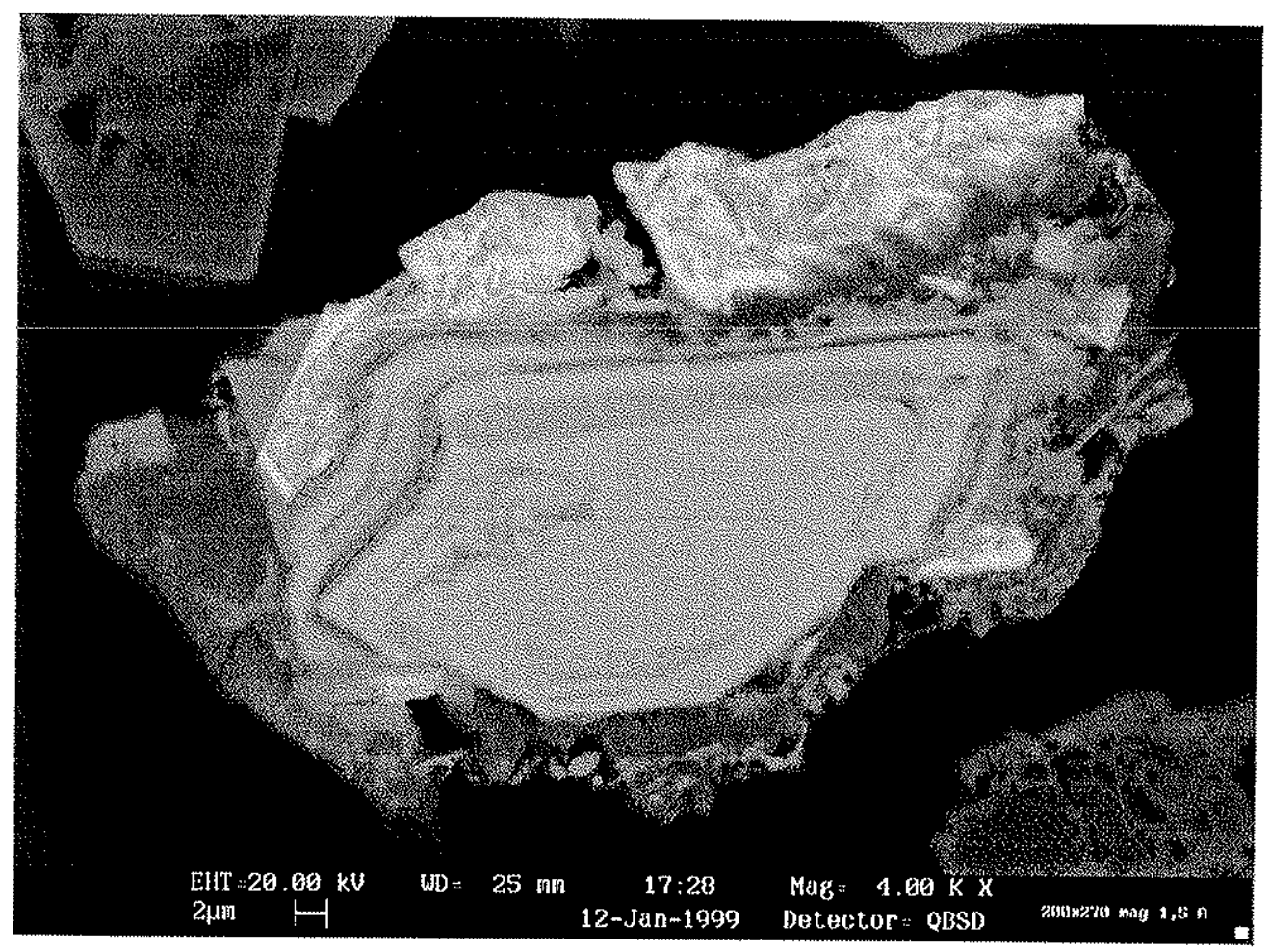

Figura 4.52 - Zirconolita zonada (cinza médio) associada a gorceixita (mais escura) e bariopirocloro (mais claro). MEV/BSD.

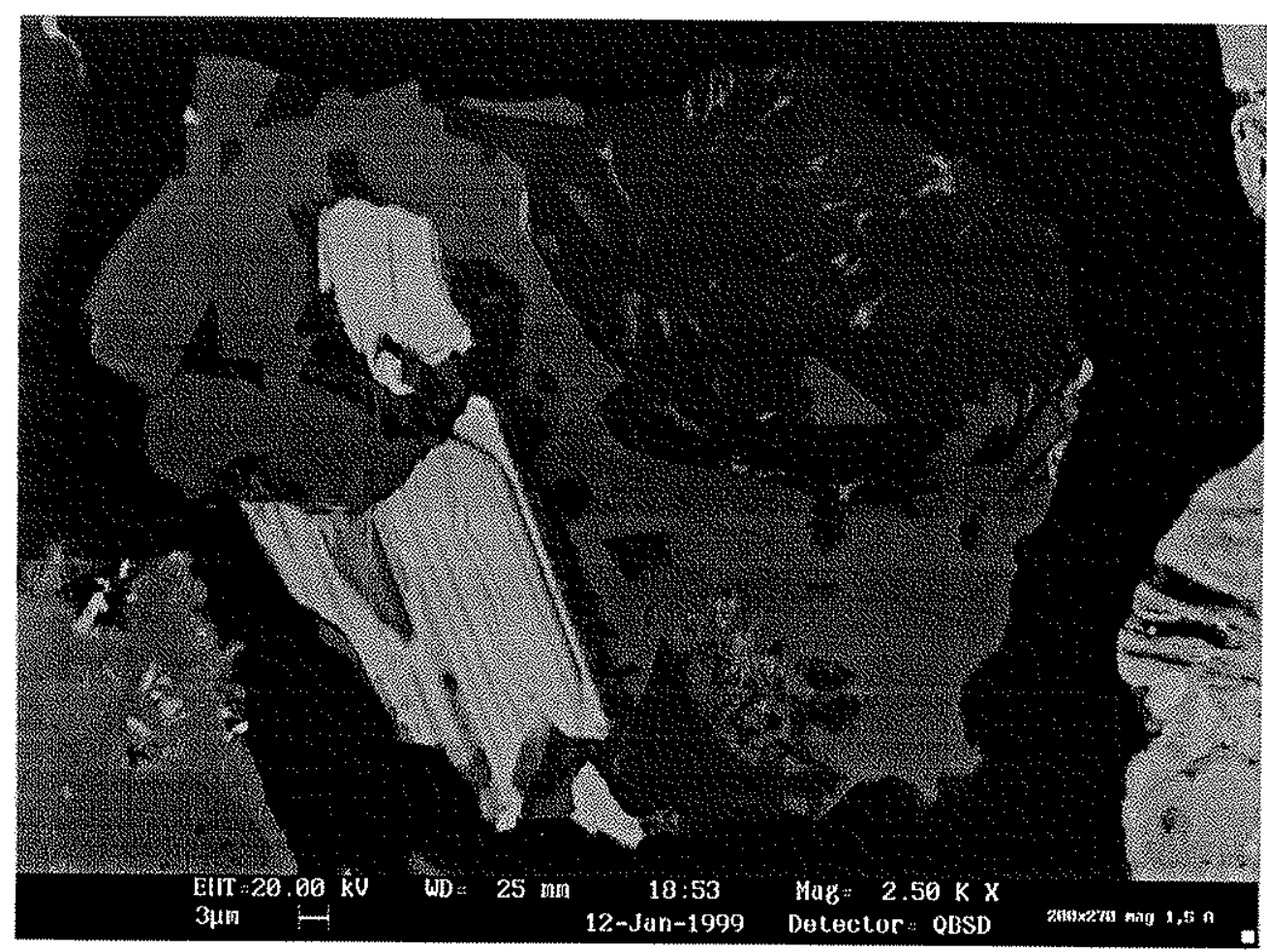

Figura 4.53 - Zirconolita zonada (mais clara) associada a apatita (cinza médio) e quartzo (mais escuro). MEV/BSD. 
Baddeleyita também foi observada nesse minério, e também é carreadora de ETR, mas contém apenas Sc como terra rara. Como já foi dito antes, Sc é um elemento de altíssimo valor no mercado, o que tornaria a recuperação desse mineral altamente interessante, se a sua presença no minério não fosse limitada a curiosidade mineralógica. No entanto, como também já foi dito, outras áreas no mesmo complexo podem ter uma concentração maior de baddeleyita, e então a presença de Sc é mais um dado importante para nortear pesquisas e investimentos.

Não é possível estabelecer associações preferenciais da baddeleyita, uma vez que ela ocorre associada a praticamente toda a assembléia mineralógica encontrada. Da mesma forma, ela pode ocorrer como restos aparentemente corroídos, como na Figura 4.51, acima, e na imagem da Figura 4.54, ou como cristais aparentemente bem formados, como nas imagens das Figuras 4.55 e 4.56

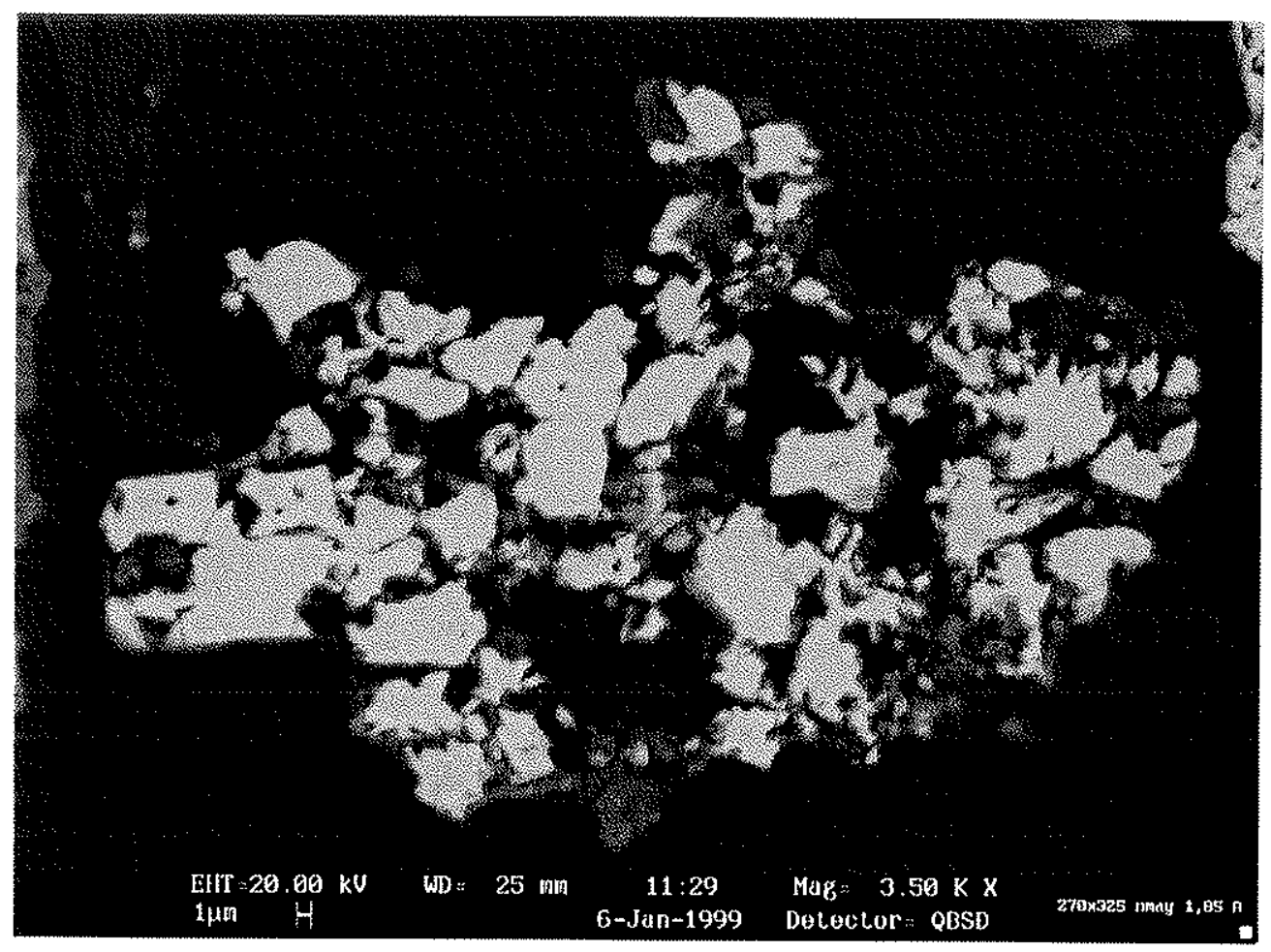

Figura 4.54 - Baddeleyita fina, aparentemente restos de um cristal maior corroido. MEV/BSD. 


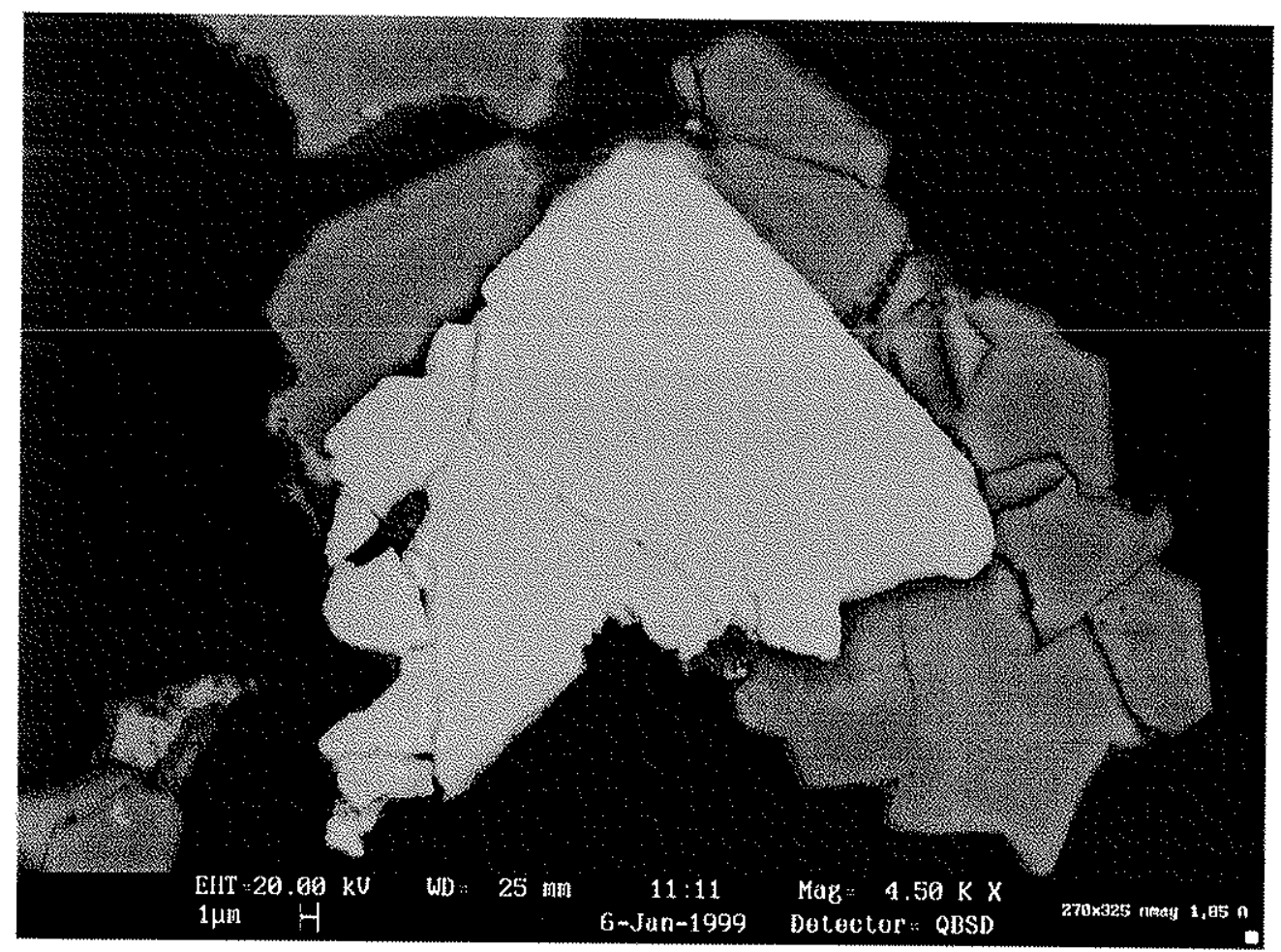

Figura 4.55 - Baddeleyita aparentemente bem cristalizada associada a apatita. MEV/BSD.

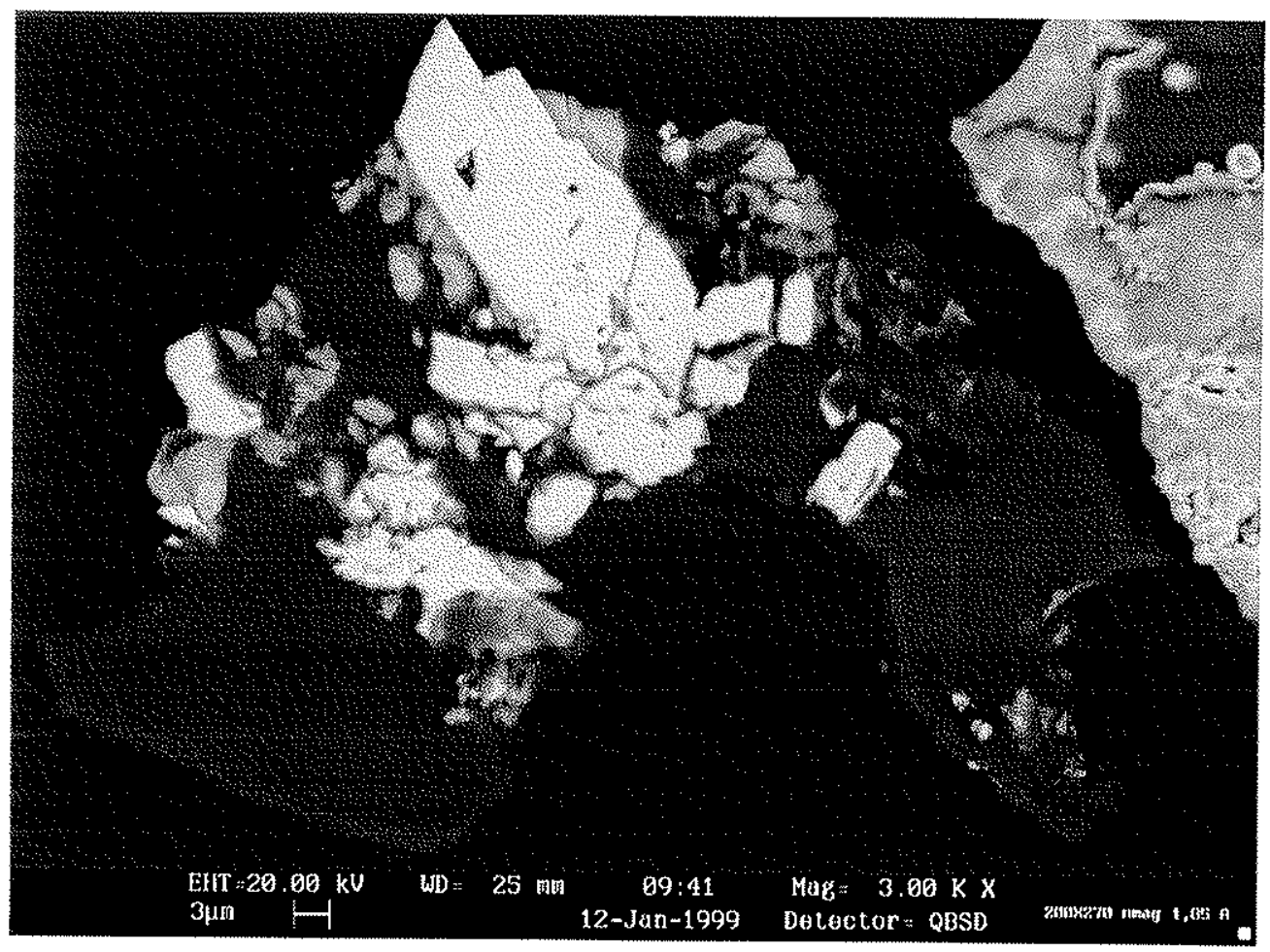

Figura 4.56 - Baddeleyita (branco) em cristal bem formado, além de fragmentos menores, em quartzo (cinza escuro), contendo também monazita (cinza médio). MEV/BSD. 
Os resultados de algumas análises por EDS de baddeleyita estão na Tabela 4.43. O teor de Sc (em óxido) varia muito, atingindo 1,5\%. Háfnio, que sempre acompanha $Z$ r, também está presente em teores relativamente elevados, atingindo quase $2,5 \%$ de seu óxido.

Tabela 4.43 - Composição de alguns grãos de baddeleyita do minério laterítico (EDS, $\%$ em massa, recalculado para $100 \%$ ). Média na última coluna, em negrito.

\begin{tabular}{lcccccc}
\hline $\mathrm{Sc}_{2} \mathrm{O}_{3}$ & 1,49 & 1,47 & 0,30 & 0,82 & 0,04 & $\mathbf{0 , 8 2}$ \\
$\mathrm{TiO}_{2}$ & 0,97 & 0,00 & 0,30 & 0,65 & 0,24 & $\mathbf{0 , 4 3}$ \\
$\mathrm{Fe}_{2} \mathrm{O}_{3}$ & 0,89 & 0,00 & 0,17 & 0,94 & 0,31 & $\mathbf{0 , 4 6}$ \\
$\mathrm{ZrO}_{2}$ & 95,23 & 98,53 & 96,74 & 92,62 & 97,43 & $\mathbf{9 6 , 1 1}$ \\
$\mathrm{Nb}_{2} \mathrm{O}_{5}$ & 0,00 & 0,00 & 0,58 & 2,57 & 0,00 & $\mathbf{0 , 6 3}$ \\
$\mathrm{HfO}_{2}$ & 1,43 & 0,00 & 1,90 & 2,40 & 1,98 & $\mathbf{1 , 5 4}$ \\
\hline
\end{tabular}

A última fase carreadora de terras raras, e que portanto é descrita com detalhamento maior, é a gorceixita. A composição da gorceixita varia um pouco, principalmente em termos de seu conteúdo em bário, estrôncio e cálcio (ou seja, seus membros gorceixita, goyazita e crandallita), mas o bário sempre predomina largamente, e gorceixita contendo exclusivamente bário é a mais comum. Uma gorceixita com variação maior na sua composição pode ser observada na imagem da Figura 4.57, e as duas composições, assim como outras duas em outros grãos, estão na Tabela 4.44. 


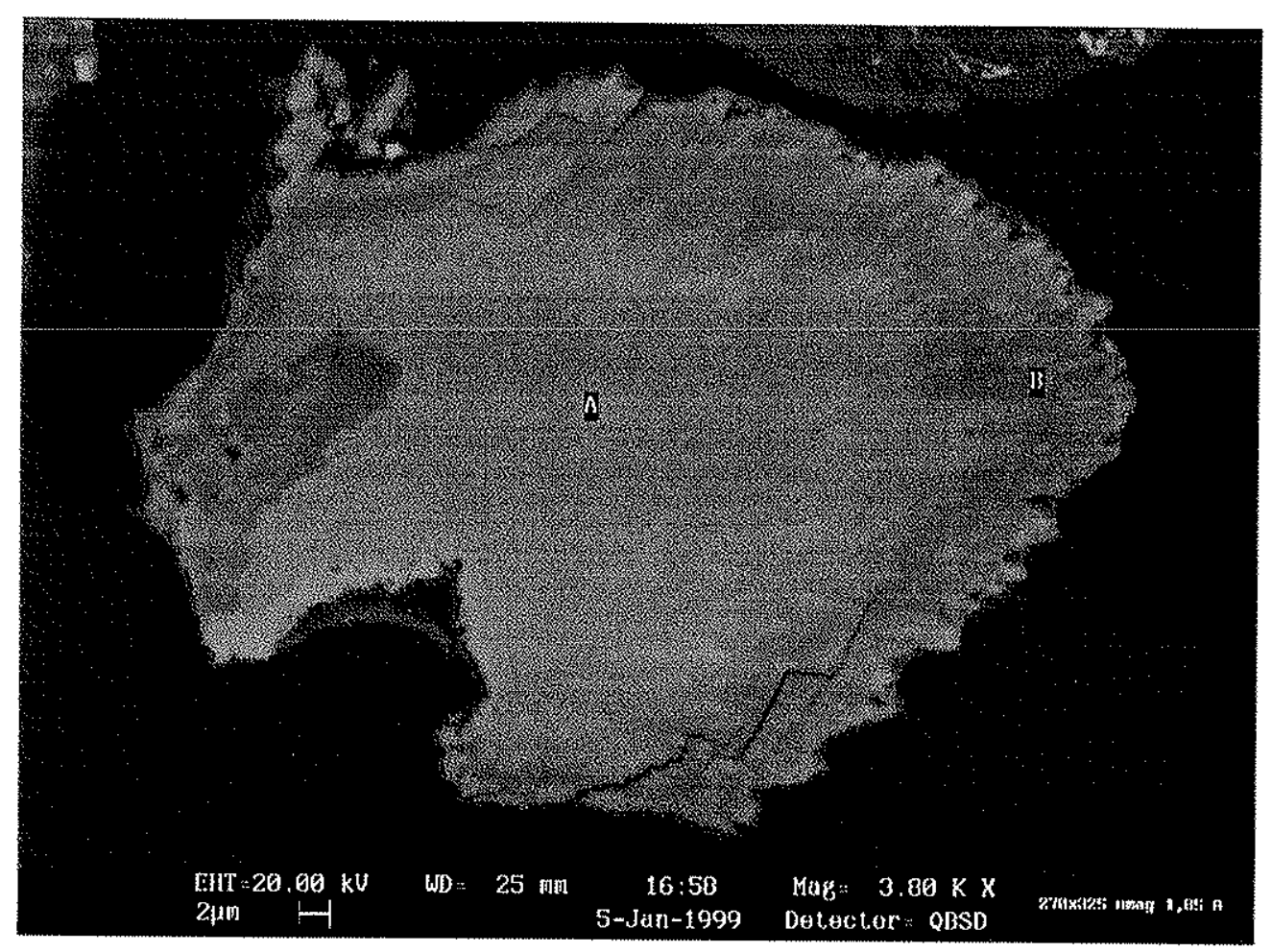

Figura 4.57 - Gorceixita com variação de composição entre seu centro (ponto A) e sua borda (ponto B), e com inclusão de cristal de apatita (à esquerda). MEV/BSD.

Tabela 4.44 - Composição química de alguns grãos de gorceixita (incluindo os pontos A e B da Figura 4.55), dados de EDS (\% em massa, recalculados para 100\%).

\begin{tabular}{|c|c|c|c|c|}
\hline \multicolumn{5}{|c|}{ Ponto A Ponto B } \\
\hline $\mathrm{O}$ & 46,03 & 46,94 & 46,82 & 44,57 \\
\hline $\mathrm{Al}$ & 15,73 & 16,60 & 13,76 & 13,90 \\
\hline Si & 0,24 & 0,20 & 0,26 & 0,17 \\
\hline$P$ & 13,09 & 13,38 & 12,67 & 12,70 \\
\hline $\mathrm{Ca}$ & 1,76 & 2,53 & 1,42 & 1,60 \\
\hline $\mathrm{Fe}$ & 0,63 & 0,43 & 3,46 & 3,61 \\
\hline $\mathrm{Sr}$ & 1,08 & 3,45 & 0,90 & 1,03 \\
\hline $\mathrm{Ba}$ & 19,83 & 15,20 & 20,12 & 20,97 \\
\hline $\mathrm{Ce}$ & 0,17 & 0,33 & 0,59 & 1,44 \\
\hline $\mathrm{Nd}$ & 1,42 & 0,94 & 0,00 & 0,00 \\
\hline$\sum$ ETR & 1,60 & 1,26 & 0,59 & 1,44 \\
\hline
\end{tabular}

O teor de ETR na gorceixita, como foi dito, varia bastante, mas nunca é alto. A gorceixita é um mineral que torna as terras raras indisponiveis para processamento, uma vez que o mineral nunca poderá gerar um concentrado com teores úteis para extração, sendo portanto deletério ao processo, da mesma forma que faz com o fósforo 
(o tosfato não-apatítico no processamento de apatita geralmente está na crandallita). Dessa forma, o baixo teor de ETR na gorceixita, e a ausência de florencita, são positivos do ponto de vista de processamento de ETR.

Duas feições são ainda muito típicas de gorceixita nesse minério. A gorceixita, com muita freqüência, apresenta-se cortada pelas folhas de minerais micáceos, vermiculita ou hidrobiotita, e provavelmente cresceu dentro do mineral, uma vez que as folhas estão afastadas pela sua presença. A imagem da Figura 4.58 ilustra isso. Além disso, é muito comum a sua associação intima com óxidos/hidróxidos de Fe, como pode ser visto na imageım da Figura 4.59. Como essa associação é muito fina, é possivel que nem sempre a trama de óxidos/hidróxidos seja perceptível, e análises de gorceixita poderiam indicar um conteúdo de $\mathrm{Fe}$ que na verdade é de outra fase, intimamente associada. As duas últimas análises de gorceixita da Tabela 4.44, acusando por volta de $3,5 \%$ do elemento, até poderiam, hipoteticamente, ser enquadradas nessa situação. 


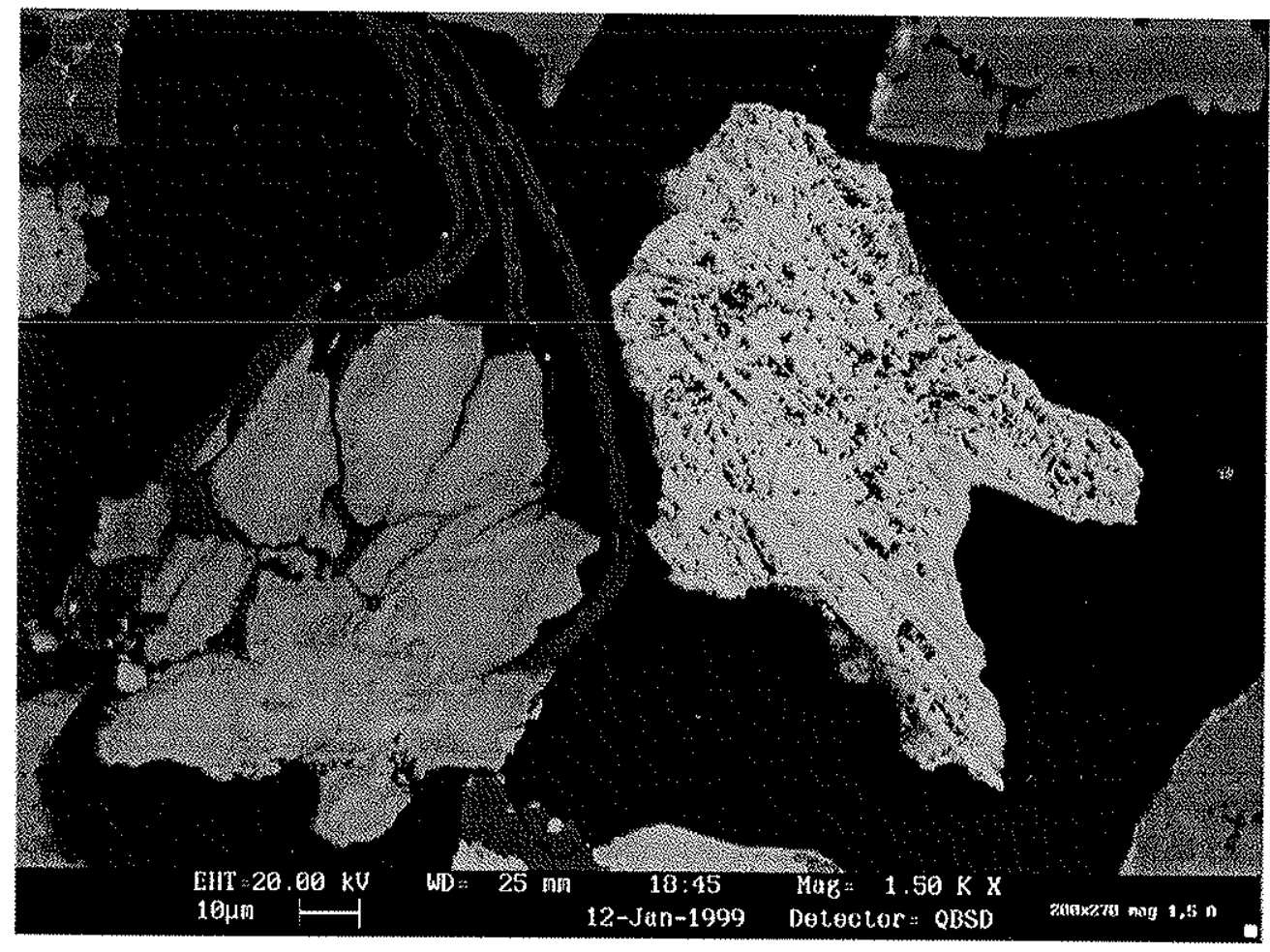

Figura 4.58 - Gorceixita dentro das folhas de hidrobiotita, ao lado de monazita maciça e predominantemente porosa. MEV/BSD.

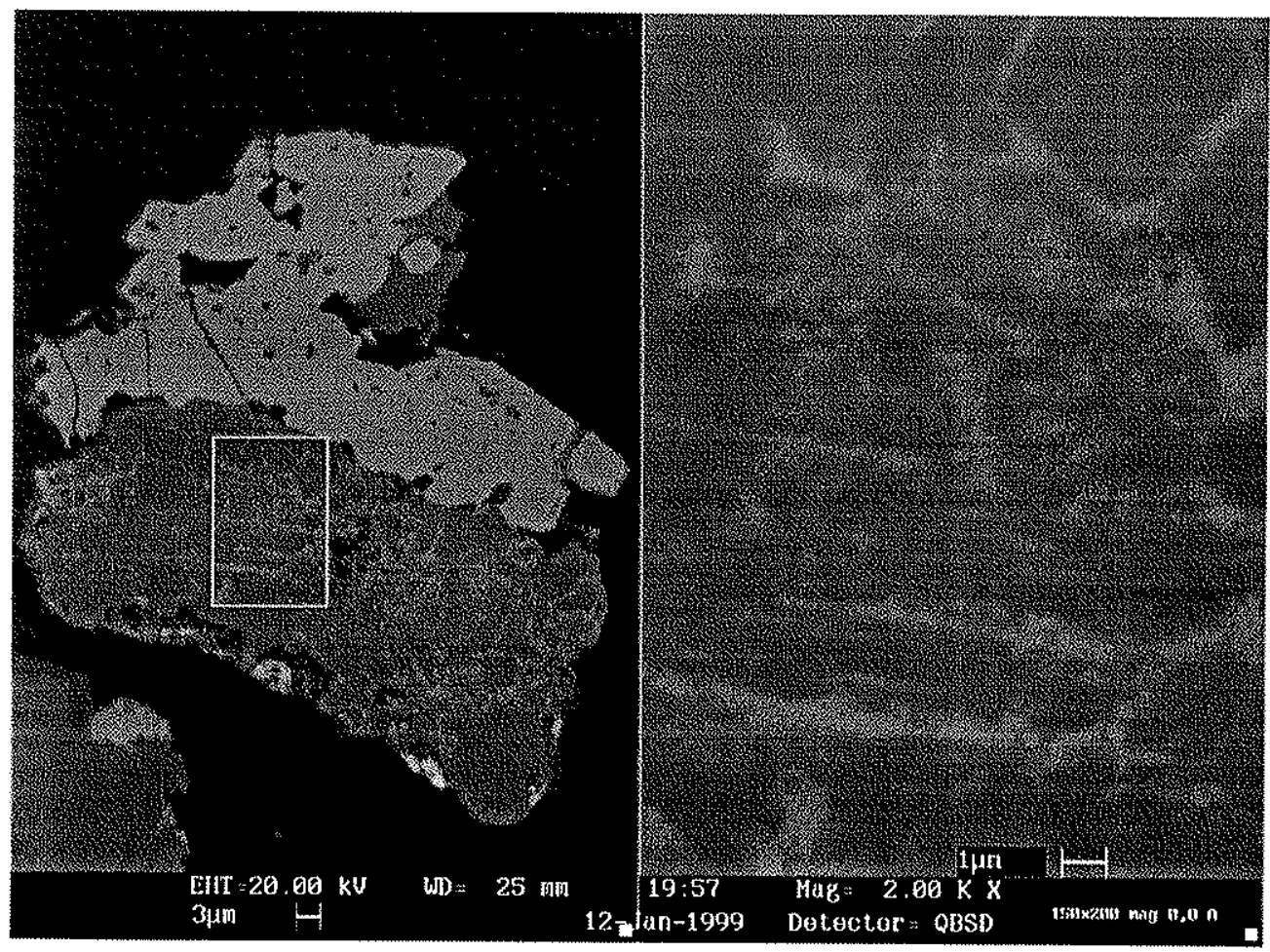

Figura 4.59 - Gorceixita (cinza escuro) permeada por finíssima trama de óxido/hidróxido de Fe, e ilmenita (cinza mais claro). MEV/BSD. 
A composição de diversos grãos de calzirtita está na Tabela 4.45. O teor de terras raras é realmente baixo, e apenas $\mathrm{Ce}$ e Sc foram detectados, e ainda assim em poucas amostras e baixa concentração. O teor de zircônio, por outro lado, é muito alto.

Tabela 4.45 - Composição de diversos grãos de calzirtita (EDS, \% massa).

\begin{tabular}{ccccccccc}
\hline $\mathrm{CaO}$ & $\mathrm{Sc}_{2} \mathrm{O}_{3}$ & $\mathrm{TiO}_{2}$ & $\mathrm{Fe}_{2} \mathrm{O}_{3}$ & $\mathrm{ZrO}_{2}$ & $\mathrm{Nb}_{2} \mathrm{O}_{5}$ & $\mathrm{CeO}_{2}$ & $\mathrm{HfO}_{2}$ & Total \\
\hline 11,94 & 0,00 & 15,77 & 1,09 & 69,54 & 0,00 & 0,27 & 0,00 & 98,61 \\
11,35 & 0,28 & 15,08 & 1,02 & 68,62 & 2,41 & 0,00 & 0,00 & 98,76 \\
11,65 & 0,20 & 14,55 & 1,65 & 69,52 & 0,00 & 0,00 & 0,00 & 97,57 \\
11,60 & 0,00 & 16,10 & 0,93 & 69,83 & 1,35 & 0,00 & 0,77 & 100,70 \\
11,63 & 0,00 & 16,28 & 0,67 & 69,43 & 0,00 & 0,07 & 1,18 & 99,25 \\
11,55 & 0,04 & 15,96 & 0,67 & 68,78 & 1,96 & 0,00 & 0,87 & 99,83 \\
11,60 & 0,00 & 16,71 & 0,98 & 69,08 & 1,77 & 0,00 & 0,93 & 102,28 \\
11,80 & 0,00 & 16,38 & 0,73 & 69,34 & 2,21 & 0,00 & 0,35 & 100,81 \\
11,90 & 0,00 & 16,32 & 0,65 & 69,61 & 1,56 & 0,00 & 0,00 & 100,03 \\
11,65 & 0,17 & 16,38 & 0,35 & 70,33 & 0,58 & 0,00 & 0,00 & 99,46 \\
11,61 & 0,08 & 15,62 & 0,70 & 70,31 & 1,12 & 0,00 & 0,41 & 99,85 \\
11,05 & 0,00 & 17,13 & 0,74 & 69,49 & 0,00 & 0,18 & 0,00 & 98,60 \\
11,92 & 0,00 & 17,06 & 0,90 & 70,53 & 0,24 & 0,00 & 0,00 & 100,65 \\
11,26 & 0,27 & 16,13 & 0,60 & 69,92 & 1,82 & 0,00 & 0,00 & 100,00 \\
\hline $\mathbf{1 1 , 6 1}$ & $\mathbf{0 , 0 8}$ & $\mathbf{1 6 , 1 1}$ & $\mathbf{0 , 8 4}$ & $\mathbf{6 9 , 6 0}$ & $\mathbf{1 , 0 7}$ & $\mathbf{0 , 0 4}$ & $\mathbf{0 , 3 2}$ & $\mathbf{9 9 , 7 4}$ \\
\hline
\end{tabular}

As imagens das Figuras 4.60 e 4.61 mostram a associação da calzirtita com bariopirocloro e com gorceixita. 


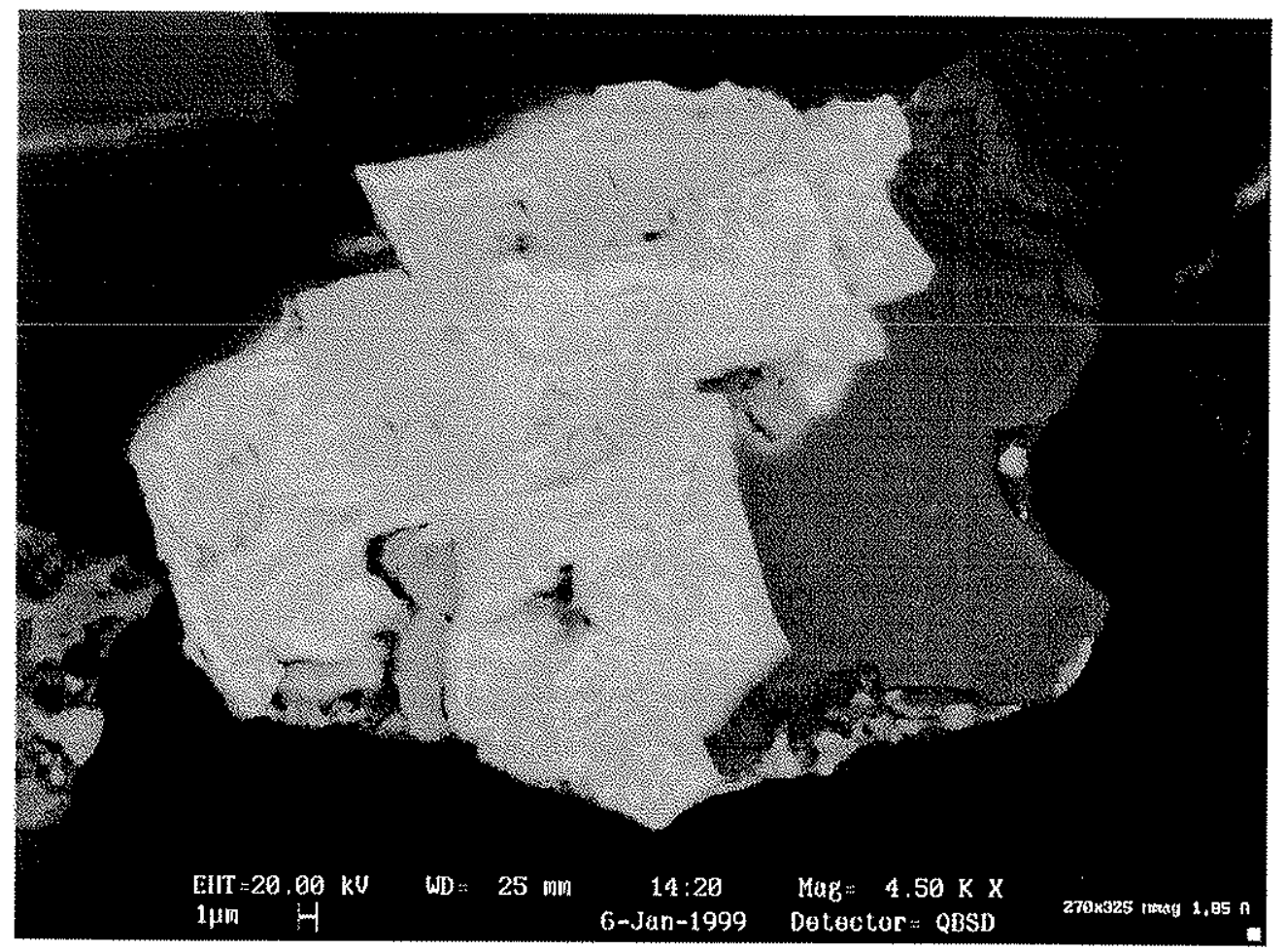

Figura 4.60 - Calzirtita (cinza intermediário) sobre bariopirocloro, e gorceixita (cinza escuro). MEV/BSD.

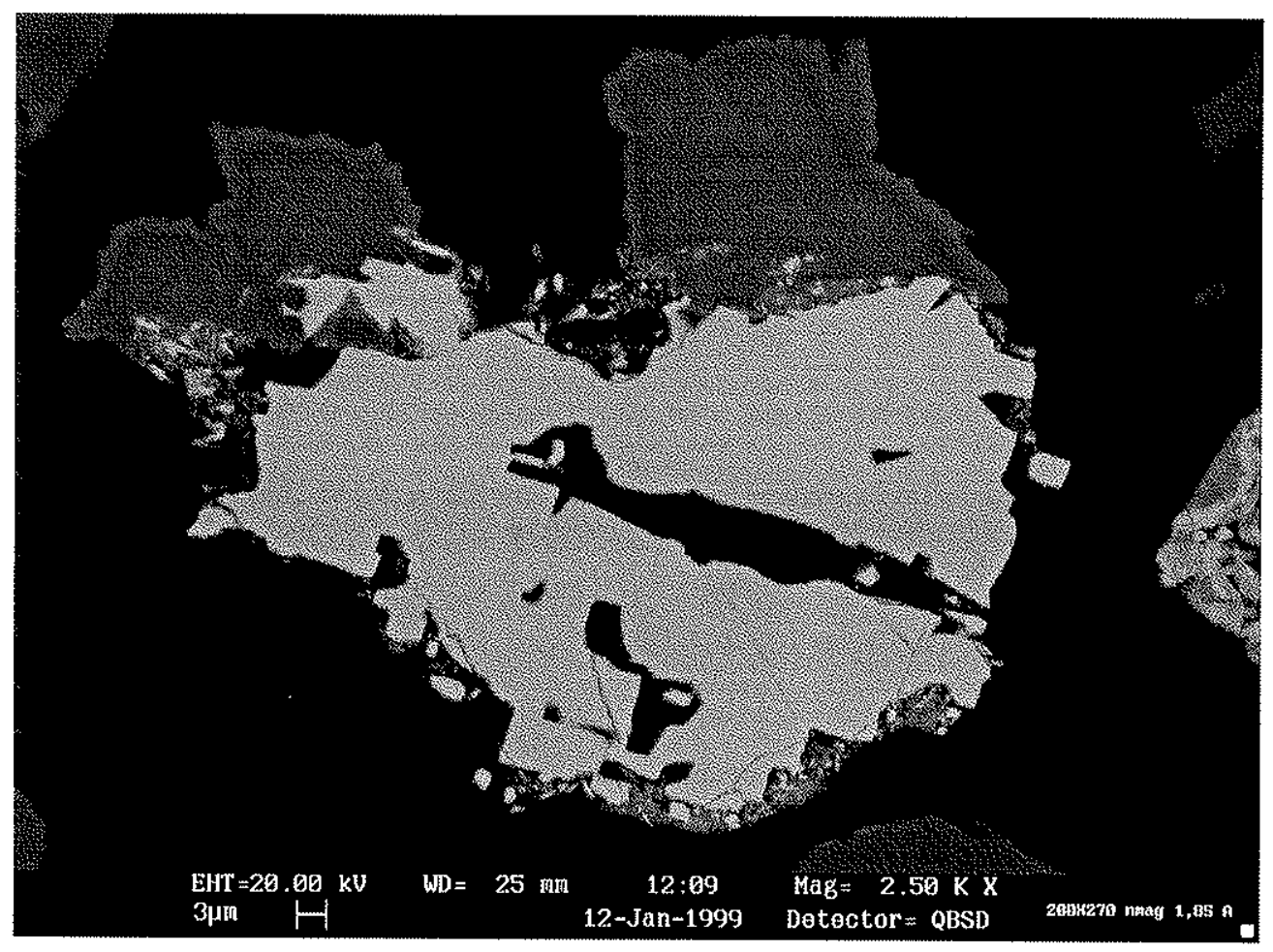

Figura 4.61 - Associação da calzirtita com gorceixita (mais escura). MEV/BSD. 
Foram descritos até aqui os minerais carreadores de ETR, desde o principal, monazita, até a gorceixita, que contém poucas terras raras e é, do ponto de vista do processamento, indesejável. Os minerais que não são portadores de terras raras, e que foram identificados por difração de raios $X$, são quartzo, ilmenita, goethita, hematita, priderita, anatásio, hidrobiotita, vermiculita e magnetita.

A ilmenita é um mineral comum no minério, e foi visto com freqüência em imagens anteriores. A composição de dois grãos de ilmenita foi medida, e os resultados estão na Tabela 4.46. Na imagem da Figura 4.62 pode ser observado um cristal bem formado de ilmenita, com mudanças de composição de seu núcleo, visualmente mais preservado, para as bordas. Análises qualitativas indicam que a composição do núcleo apresenta alto teor de $\mathrm{Mn}$ e, obviamente, $\mathrm{Fe}$ e $\mathrm{Ti}$, mas com redução drástica de $\mathrm{Mn}$, e depois de $\mathrm{Fe}$, em direção às bordas. Nas bordas, aumenta o teor de $\mathrm{Nb}$. Possivelmente trata-se da passagem de ilmenita para ilmenorutilo, apesar de ilmenorutilo não ter sido identificado por difração de raios $X$.

Tabela 4.46 - Composição de dois grãos de ilmenita (EDS, \% em massa, recalculado para $100 \%$ ).

\begin{tabular}{lcc}
\hline $\mathrm{MgO}$ & 1,07 & 0,46 \\
$\mathrm{TiO}_{2}$ & 51,07 & 51,06 \\
$\mathrm{MnO}$ & 5,25 & 5,22 \\
$\mathrm{Fe}_{2} \mathrm{O}_{3}$ & 42,61 & 41,22 \\
$\mathrm{ZrO}_{2}$ & 0,00 & 0,19 \\
$\mathrm{Nb}_{2} \mathrm{O}_{5}$ & 0,00 & 1,85 \\
\hline
\end{tabular}




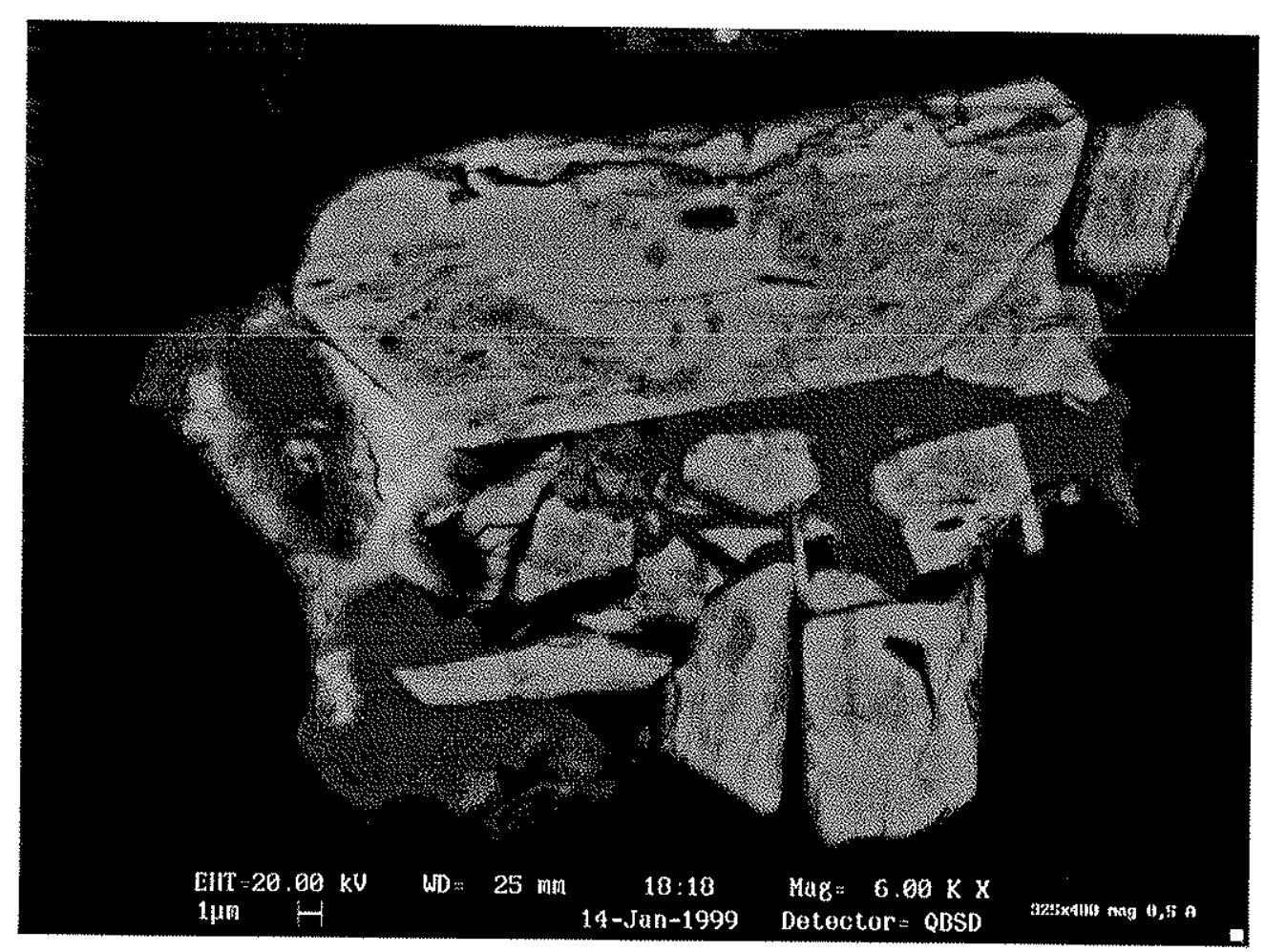

Figura 4.62 - Cristal bem formado de ilmenita, mais fragmentos, cimentados por apatita. No cristal melhor formado, observa-se passagem de ilmenita no centro, tipica no minério com alto $\mathrm{Mn}$, para fases com baixo $\mathrm{Mn}$ e perda de $\mathrm{Fe}$ em direção às bordas, terminando com Nb mais elevado na borda do grão (provável passagem para ilmenorutilo). MEV/BSD.

Óxido de Ti é uma fase razoavelmente comum no minério. A partir dos resultados da difração de raios $X$, que só identificou anatásio, optou-se por considerar todo o óxido de Ti encontrado ao MEV também como anatásio. O hábito do anatásio é sempre de cristais aciculares/lenticulares, lembrado "grãos de arroz", como pode ser visto na imagem da Figura 4.63. Além do hábito característico, o anatásio apresenta também uma composição bastante constante, como pode ser visto na Tabela 4.47 , contendo sempre Fe e $\mathrm{Nb}$, e esporadicamente $\mathrm{Zr}$. 


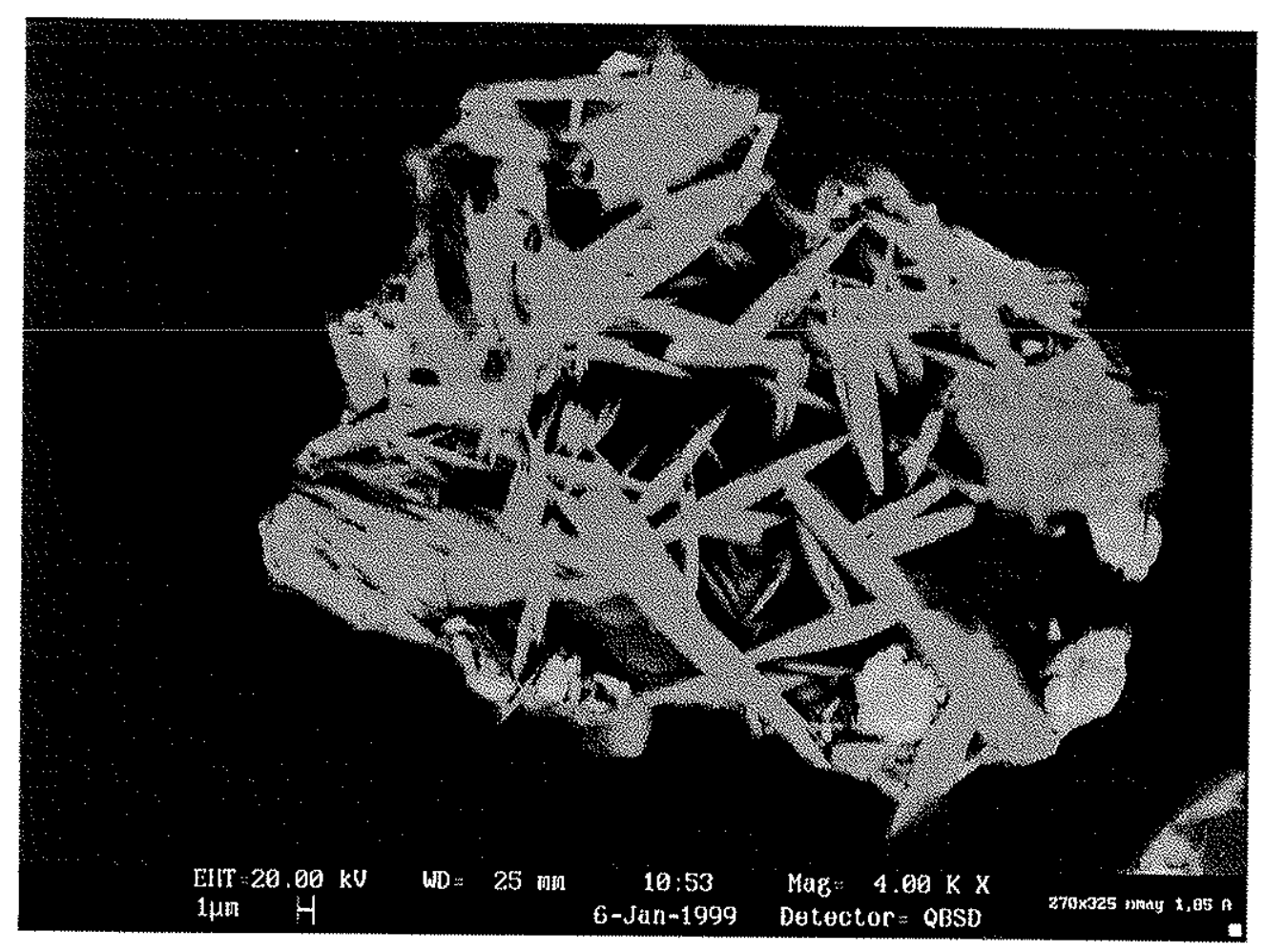

Figura 4.63 - Cristais aciculares/lenticulares de anatásio, em arranjo com alta porosidade, e alguma monazita associada (mais clara). MEV/BSD.

Tabela 4.47 - Composição de anatásio, determinada por EDS (\% massa, recalculada para $100 \%$ ).

\begin{tabular}{lcccc}
$\mathrm{TiO}_{2}$ & 91,36 & 92,47 & 92,62 & 93,47 \\
$\mathrm{Fe}_{2} \mathrm{O}_{3}$ & 2,72 & 3,58 & 1,03 & 1,61 \\
$\mathrm{ZrO}_{2}$ & 2,25 & 0,00 & 2,58 & 0,73 \\
$\mathrm{Nb}_{2} \mathrm{O}_{5}$ & 3,67 & 3,95 & 3,78 & 4,19 \\
\hline
\end{tabular}

A associação mais comum do anatásio é com quartzo, como pode ser visto na imagem da Figura 4.64. A decomposição da priderita aparentemente pode gerar anatásio, como pode ser observado na imagem da Figura 4.65, representando outra associação relativamente comum, quando há priderita. 


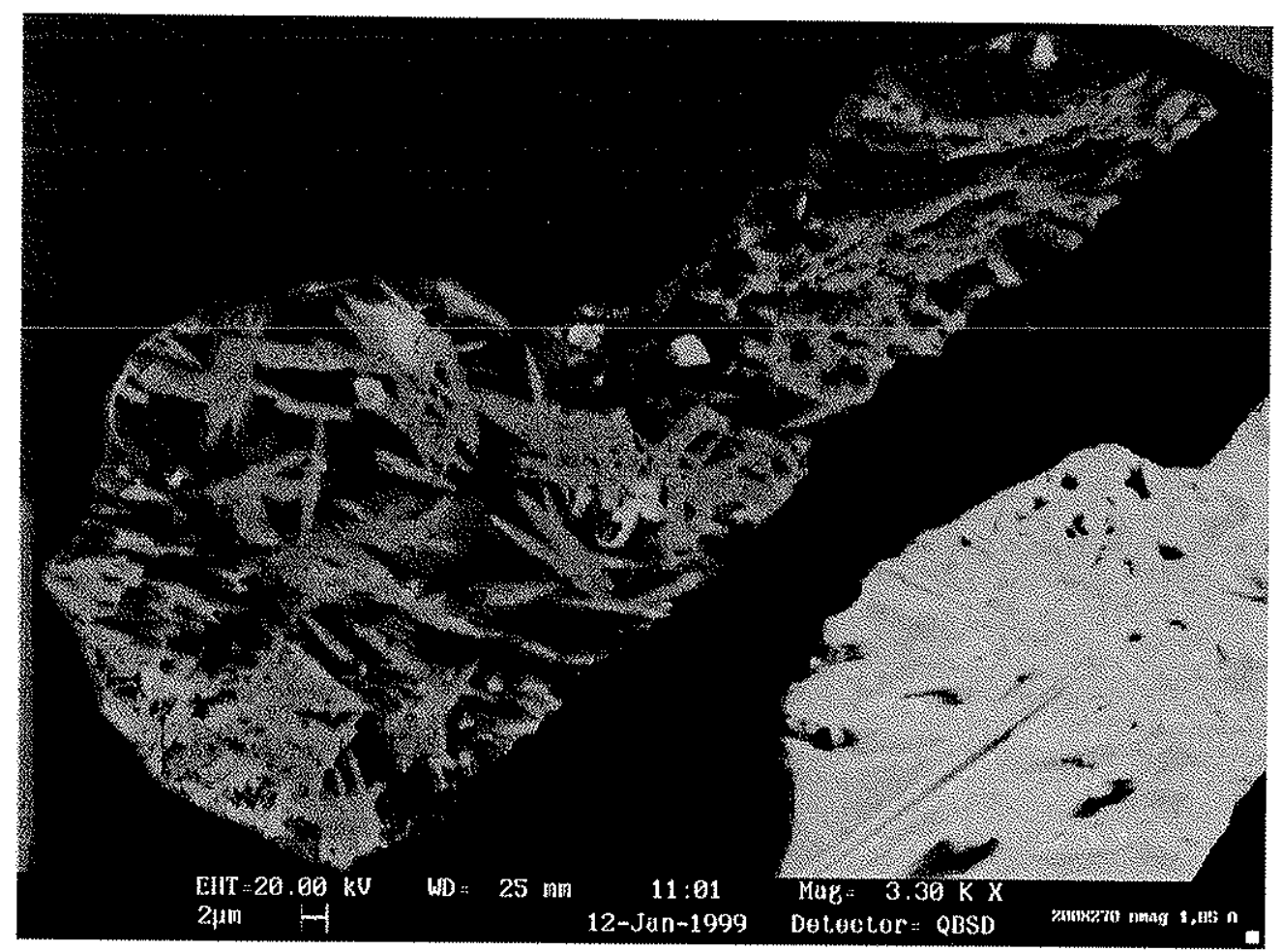

Figura 4.64 - Cristais aciculares/lenticulares de anatásio em quartzo, ao lado de grão de monazita porosa (mais clara). MEV/BSD.

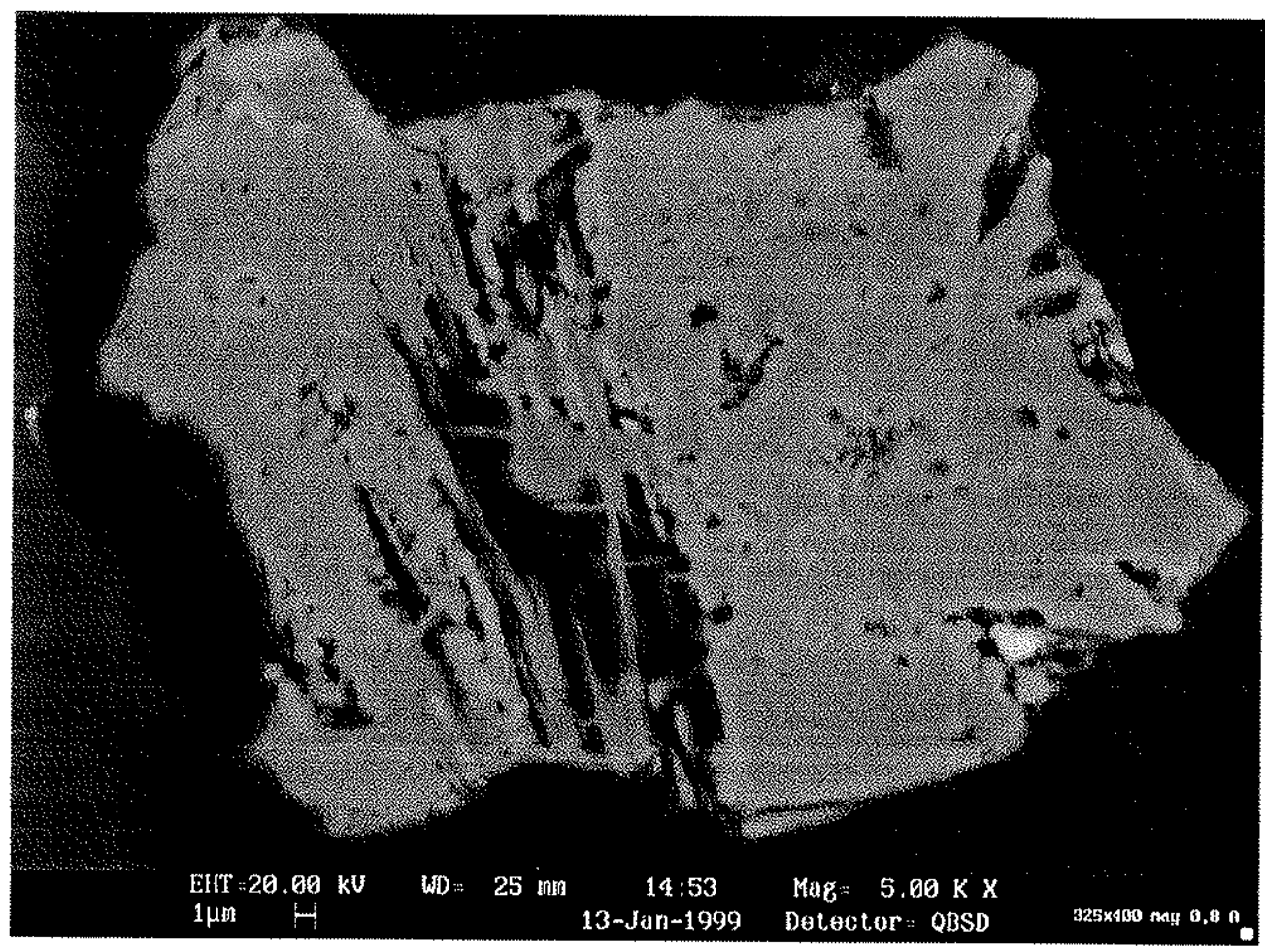

Figura 4.65 - Cristais aciculares/lenticulares de anatásio, aparentemente restando da dissolução da faixa central de um cristal de priderita. MEV/BSD. 
A priderita é um acessório comum no minério laterítico. A sua identificação foi mais difícil, no início, pela completa ausência de $\mathrm{Ba}$ em todos os grãos que foram analisados, ao contrário do que estabelecem a bibliografia (Gaspar et al. 1994) e a ficha de difração de raios X (ICDD 1996). Algumas análises químicas pontuais por EDS estão reproduzidas na Tabela 4.48. A média das análises (sem recálculo) fornece uma fórmula estrutural da priderita $\mathrm{K}_{1,33}(\mathrm{Ti}, \mathrm{V}, \mathrm{Cr}, \mathrm{Fe}, \mathrm{Nb})_{8,1} \mathrm{O}_{16}$, que é exatamente a fórmula apresentada na ficha 6-296 (ICDD 1996). Como pode ser observado na Tabela 4.48, o teor de Sc e Zr é muito baixo, e esses elementos foram excluídos da fórmula estrutural, mas como são elementos de maior valor agregado devem ser lembrados. A mesma ficha também estabelece que priderita sintética exclusivamente potássica fornece padrão de difração idêntico ao do mineral contendo $\mathrm{Ba}$, de maneira que um melhor refinamento dos dados (incluindo análises por microssonda, mais confiáveis) pode definir um novo mineral, em Catalão, uma vez que a identificação por DRX também pode ser muito boa.

Tabela 4.48 - Composição química de priderita (EDS, \% massa, não recalculado).

\begin{tabular}{lccc}
\hline $\mathrm{K}_{2} \mathrm{O}$ & 8,55 & 8,34 & 9,34 \\
$\mathrm{Sc}_{2} \mathrm{O}_{3}$ & 0,20 & 0,00 & 0,00 \\
$\mathrm{TiO}_{2}$ & 78,65 & 80,21 & 79,22 \\
$\mathrm{~V}_{2} \mathrm{O}_{3}$ & 0,00 & 1,53 & 0,00 \\
$\mathrm{Cr}_{2} \mathrm{O}_{3}$ & 0,00 & 1,58 & 0,00 \\
$\mathrm{Fe}_{2} \mathrm{O}_{3}$ & 9,90 & 8,77 & 9,64 \\
$\mathrm{ZrO}_{2}$ & 0,26 & 0,00 & 0,26 \\
$\mathrm{Nb}_{2} \mathrm{O}_{5}$ & 1,28 & 0,00 & 0,97 \\
\hline Total & 98,83 & 100,42 & 99,44 \\
\hline
\end{tabular}

A priderita geralmente aparece como cristais com as bordas corroídas, mas foi possivel encontrar um cristal aparentemente bem formado, como pode ser observado na imagem da Figura 4.66. Uma das associações preferenciais da priderita, com anatásio que possivelmente dela se origina, já foi ilustrada na imagem da Figura 4.65, 
acima. A priderita pode ser observada com praticamente todos os minerais presentes no minério. As imagens das Figuras 4.67 e 4.68 mostram associação, respectivamente, com monazita e com ilmenita, apatita e monazita.

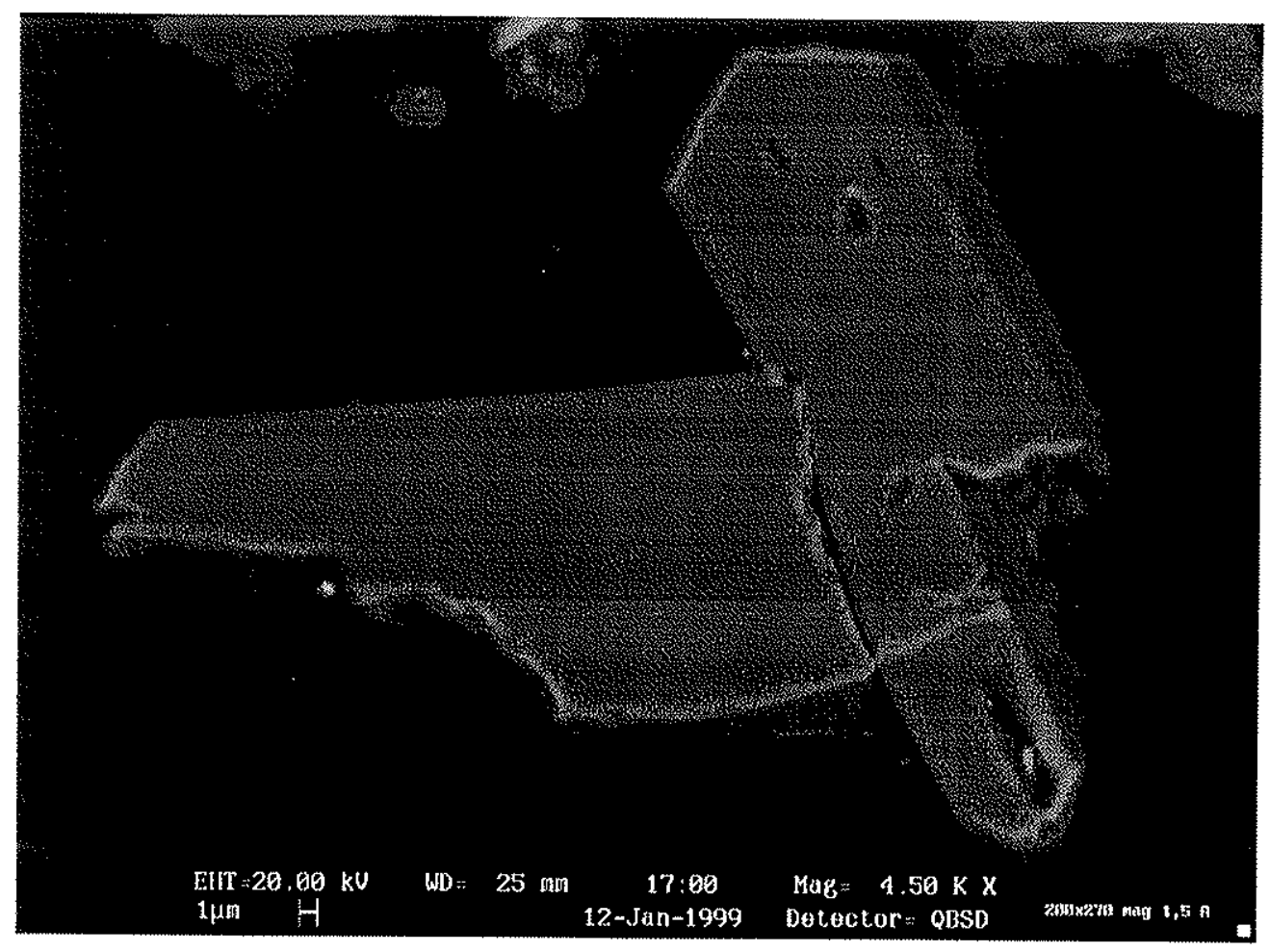

Figura 4.66 - Cristal aparentemente bem formado de priderita. MEV/BSD. 


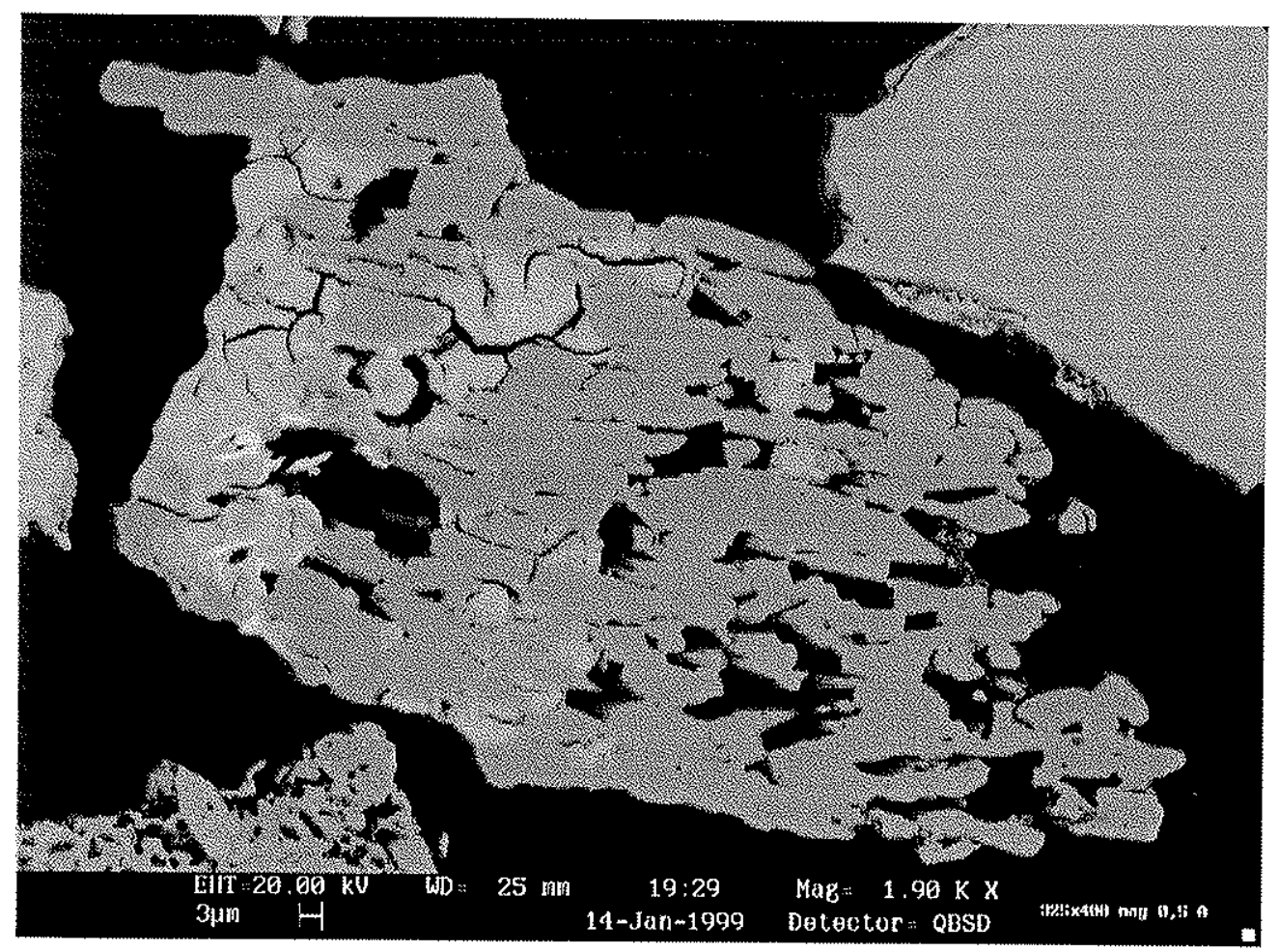

Figura 4.67 m Cristal bastante corroído de priderita, com inclusões de monazita (mais clara). MEV/BSD.

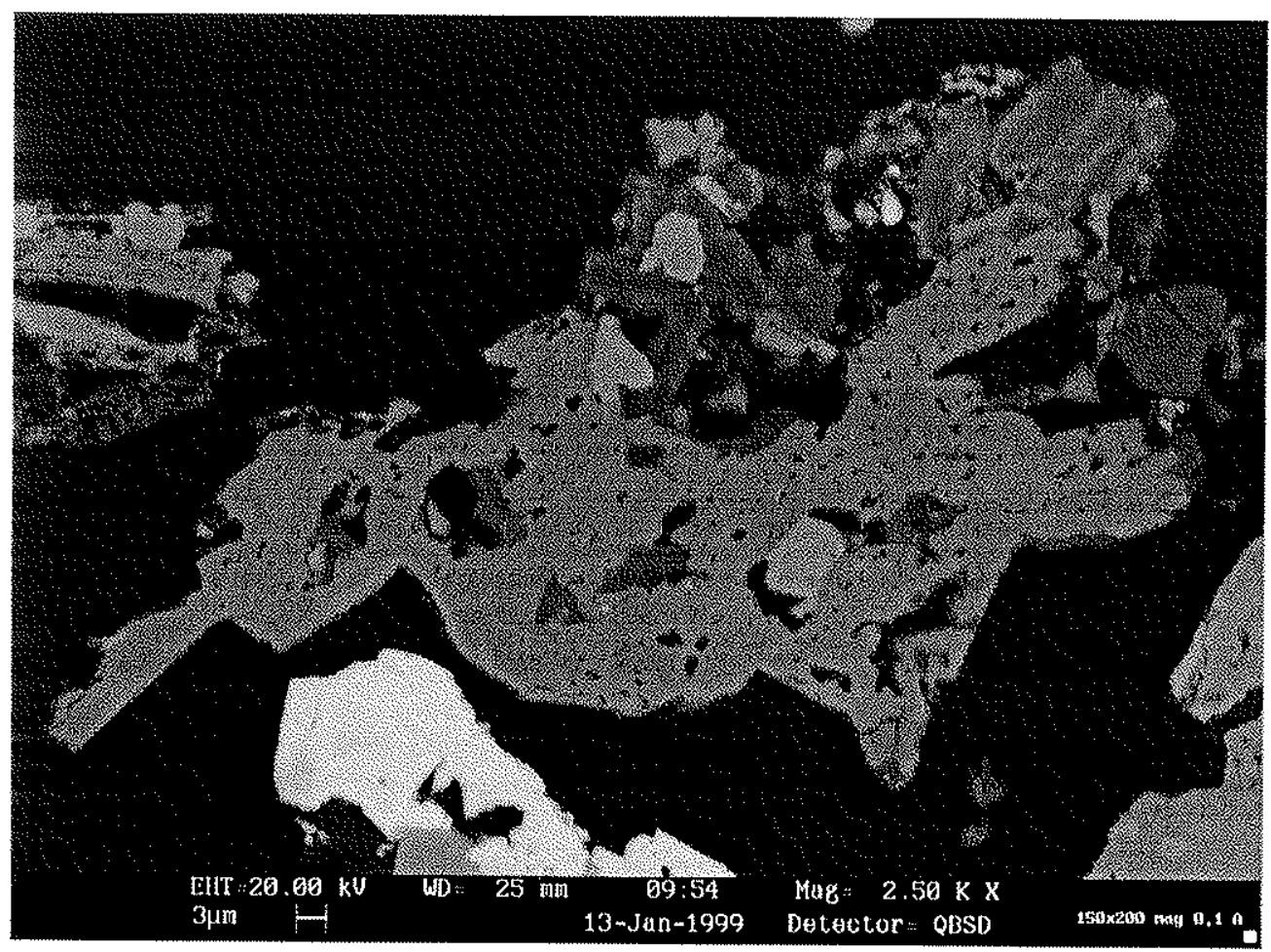

Figura 4.68 - Cristal de priderita com inclusões de ilmenita (mais clara) e apatita (mais escura), além de uma pequena de monazita (branca). MEV/BSD. 
A única feição mais interessante da magnetita é o seu eventual intercrescimento com ilmenita, provavelmente na forma de exsoluções de ilmenita que crescem respeitando planos cristalográficos da magnetita hospedeira. A imagem da Figura 4.69 ilustra essa exsoluções.

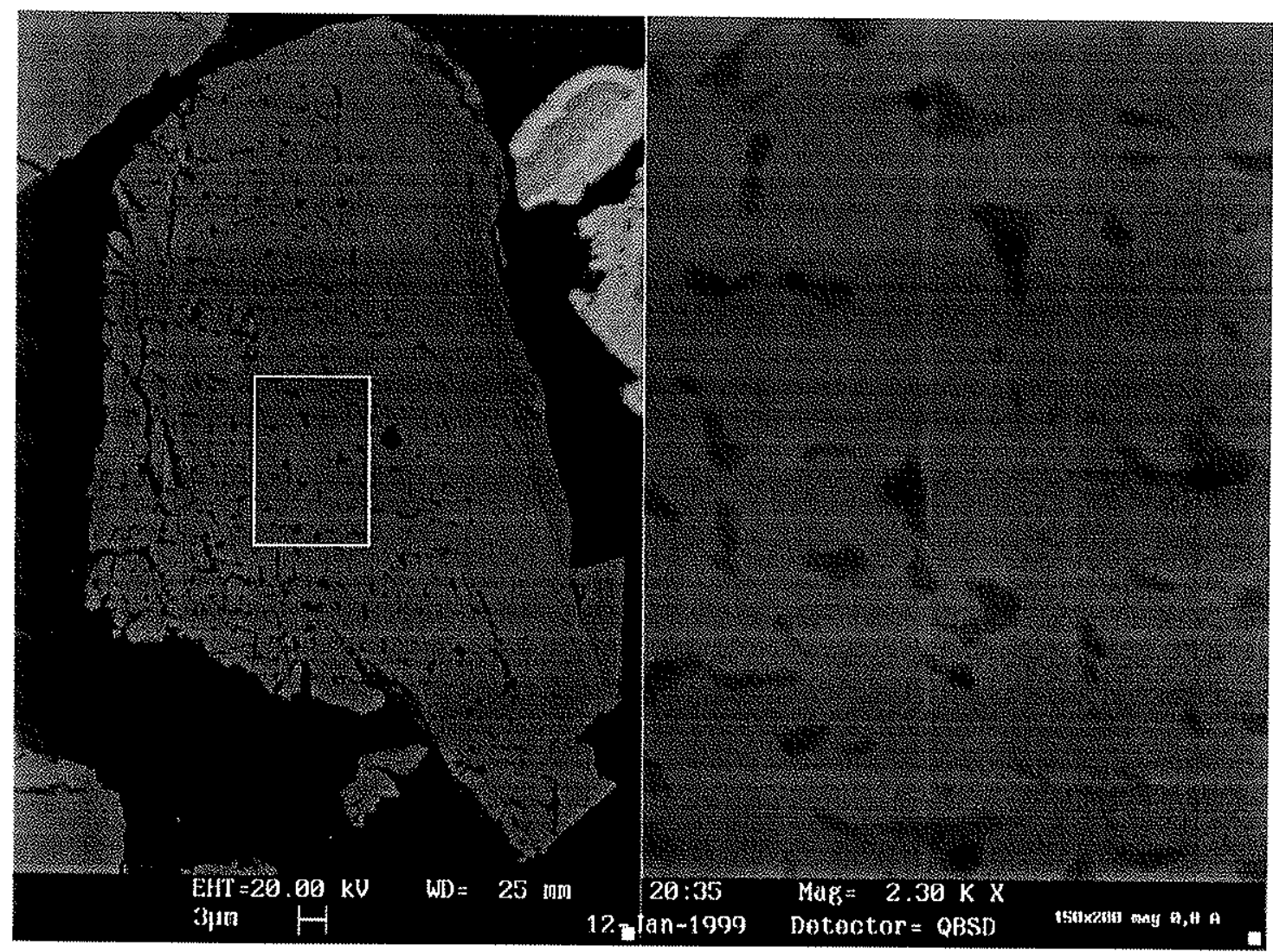

Figura 4.69 - Magnetita com exsoluções de ilmenita, mais escuras, inclusive no detalhe. À direita do grão ilmenita maciça em contato com porção da magnetita sem as exsoluções, podendo significar migração e concentração da ilmenita. MEV/BSD.

Vermiculita e o que foi identificado, de maneira mais genérica, como hidrobiotita, não são separáveis visualmente ao MEV, e o critério é a presença de $\mathrm{K}_{2} \mathrm{O}$ na mica ou não, indicando que se trata, respectivamente, de hidrobiotita ou de vermiculita. Ambos os minerais estão sempre intensamente associados a fases ferruginosas, mais especificamente ao que se considera óxidos/hidróxidos de $\mathrm{Fe}$ amorfos ou mal cristalizados (limonita). É muito freqüente o crescimento de gorceixita dentro das folhas 
das micas, como já foi explicitado anteriormente. A composição de algumas hidrobiotitas e de algumas vermiculitas está na Tabela 4.49, e a associação/substituição de micas por óxidos/hidróxidos de $\mathrm{Fe}$, além de associação com gorceixita, está nas imagens das Figuras 4.70, 4.71 e 4.72. Observam-se diversos estágios de evolução, desde a cristalização de minerais de Fe entre os planos até a substituição total da mica por óxido/hidróxido de $\mathrm{Fe}$.

Tabela 4.49 - Composição química de algumas hidrobiotitas e vermiculita (EDS, \% massa).

\begin{tabular}{lccccc}
\hline & Hidrobiotita & Hidrobiotita & Vermiculita & Vermiculita & Vermiculita \\
\hline $\mathrm{O}$ & 43,52 & 45,98 & 43,84 & 45,67 & 37,34 \\
$\mathrm{Na}$ & 0,65 & 0,37 & 0,09 & 0,00 & 0,00 \\
$\mathrm{Mg}$ & 14,77 & 13,88 & 14,99 & 16,51 & 2,51 \\
$\mathrm{Al}$ & 5,27 & 8,38 & 8,98 & 8,40 & 13,31 \\
$\mathrm{Si}$ & 19,80 & 17,20 & 18,30 & 16,25 & 16,12 \\
$\mathrm{~K}$ & 4,76 & 4,37 & 0,00 & 0,01 & 0,00 \\
$\mathrm{Ca}$ & 0,57 & 0,28 & 0,47 & 0,42 & 0,05 \\
$\mathrm{Ti}$ & 5,90 & 0,68 & 2,42 & 0,00 & 0,00 \\
$\mathrm{Fe}$ & 0,00 & 5,99 & 0,00 & 3,91 & 2,26 \\
\hline Total & 95,24 & 97,13 & 89,08 & 91,17 & 71,59 \\
\hline
\end{tabular}

A qualidade da última análise à direita (correspondente à vermiculita da imagem da Figura 4.71) aparentemente deixa a desejar, mas provavelmente a porosidade entre as folhas de mica é que provoca o baixo fechamento; o forte decréscimo no teor de $\mathrm{Mg}$ também sugere a possibilidade de caulinização dessa mica, restando da composição original apenas $\mathrm{Si}, \mathrm{Al}$ e $\mathrm{O}$, apesar de caolinita nunca ter sido detectada por difração de raios $\mathrm{X}$. 


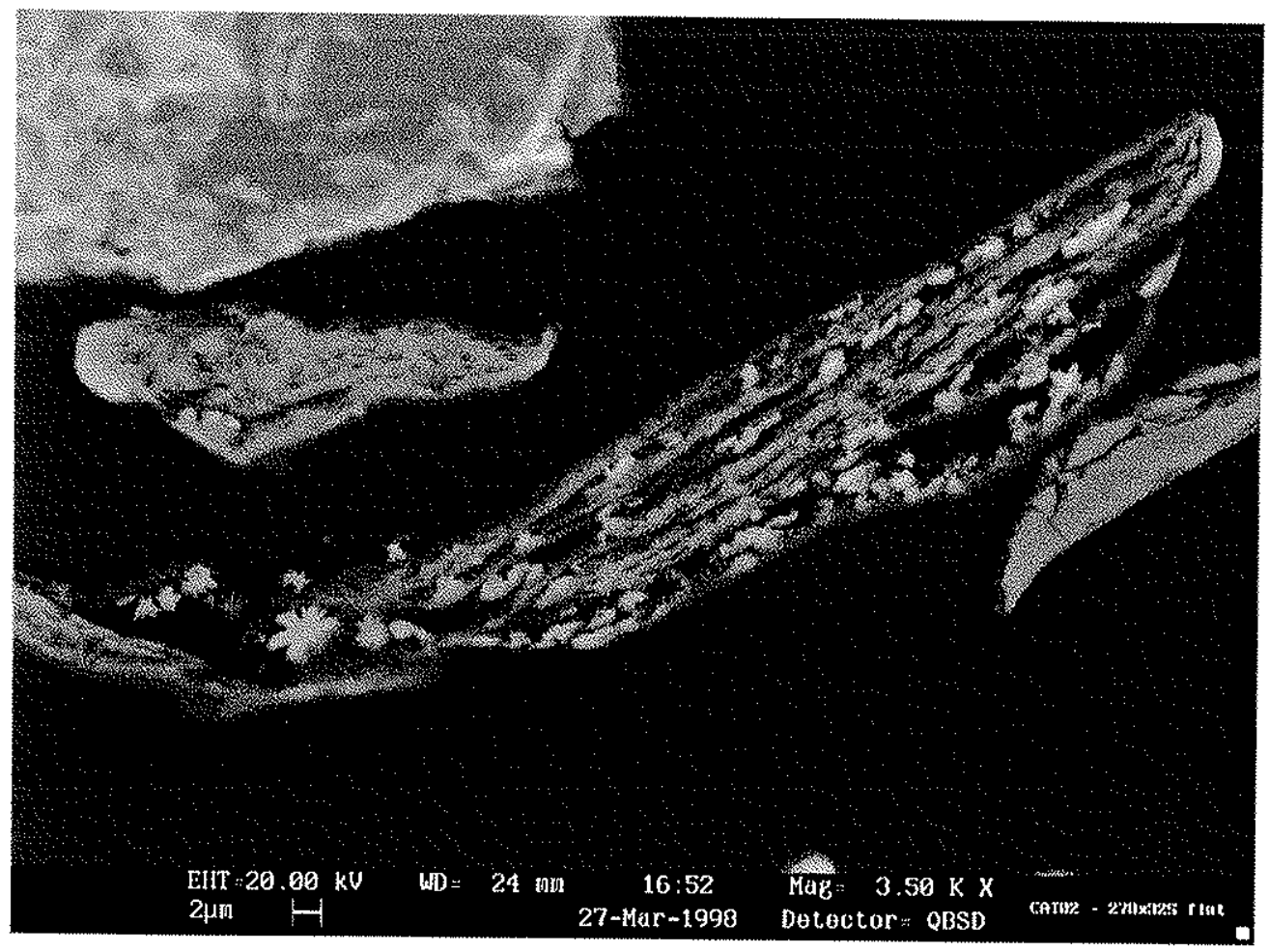

Figura 4.70 - Formação de cristais aciculares de óxido/hidróxido de Fe entre as folhas de vermiculita. Hidrobiotita logo acima, à esquerda. MRV/BSD.

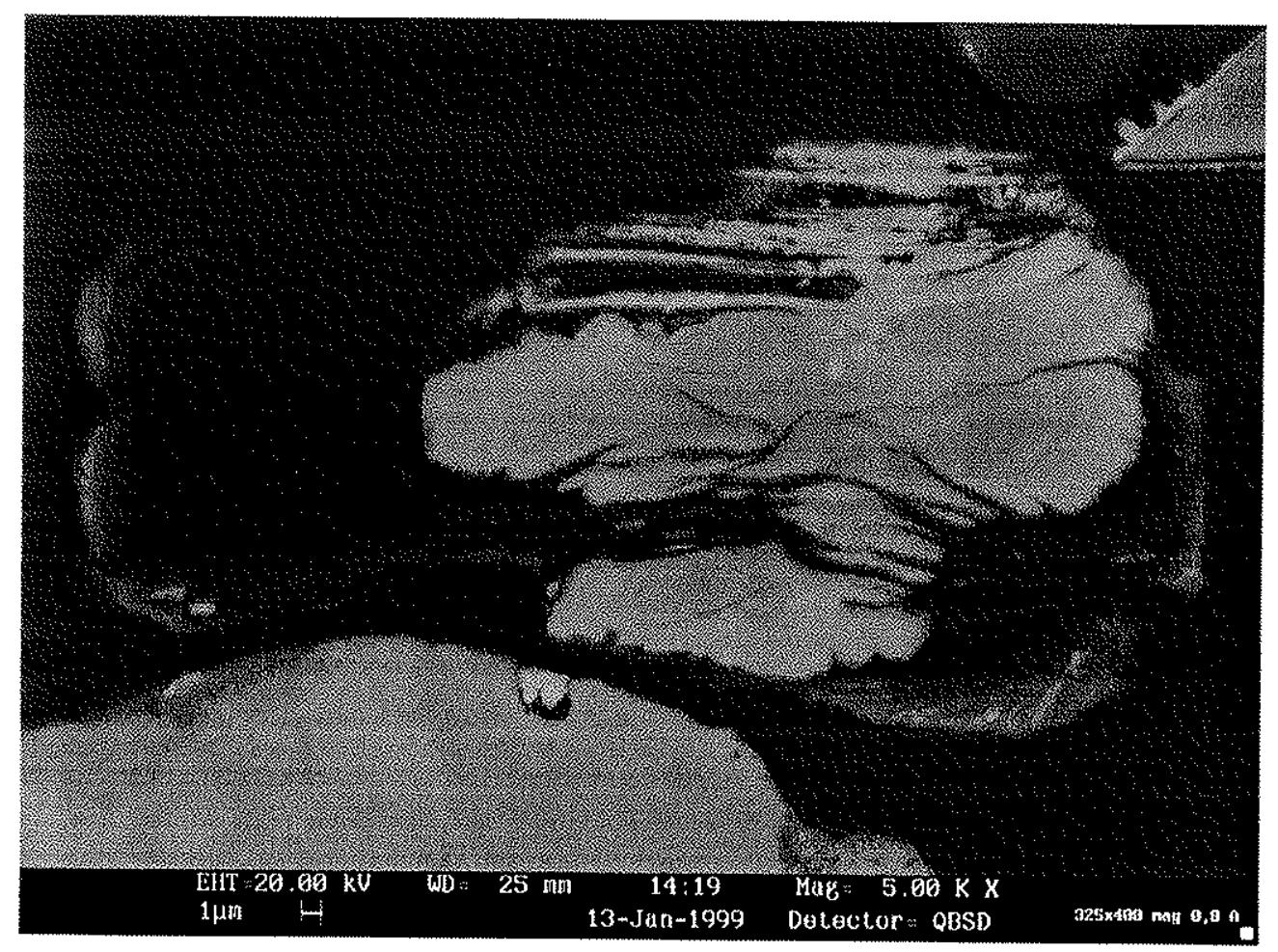

Figura 4.71 - Crescimento de gorceixita entre as folhas de vermiculita, já substituida por óxidos/hidróxidos de $\mathrm{Fe}$, na parte superior. MEV/BSD. 


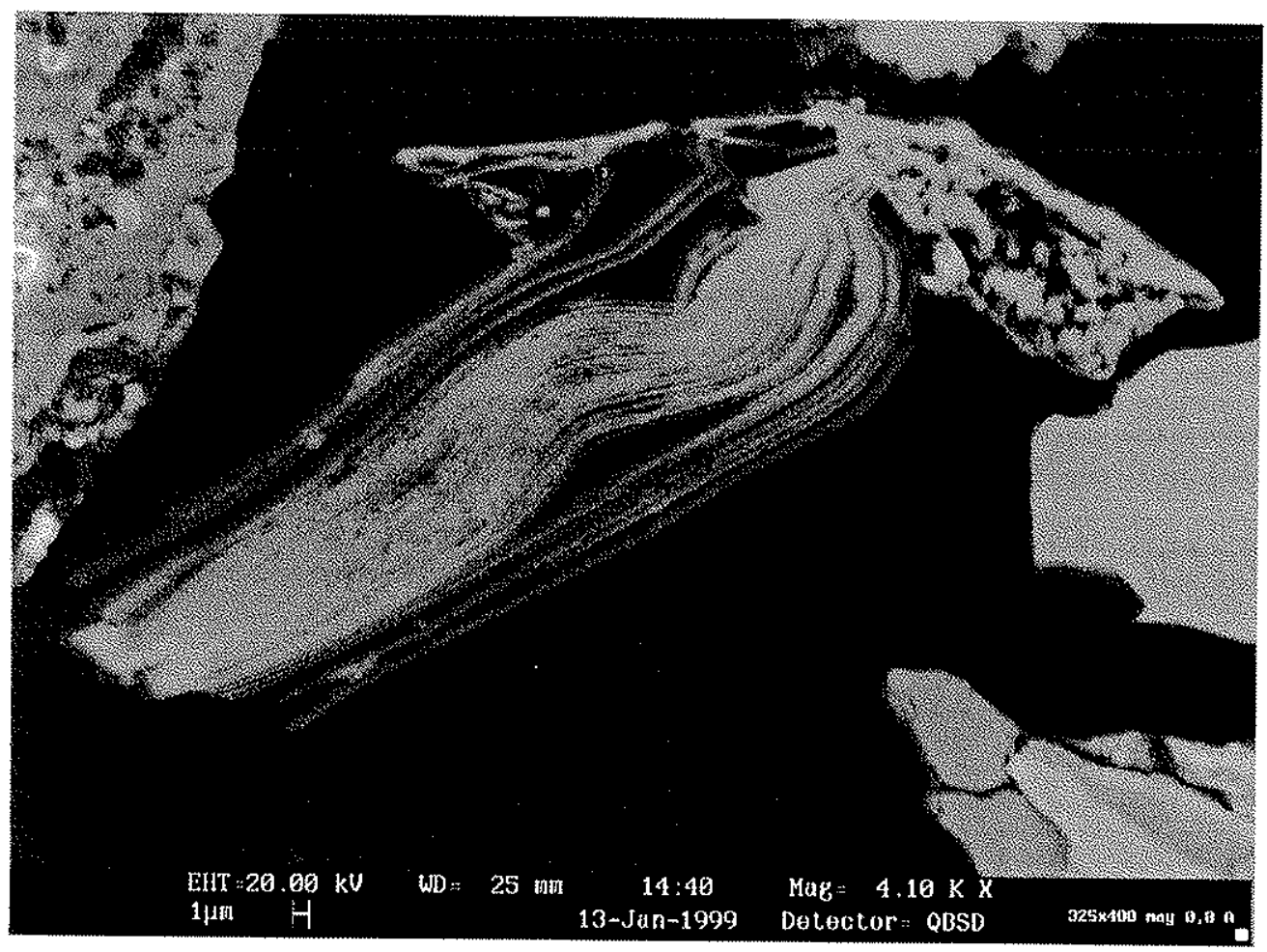

Figura 4.72 - Substituição total das folhas de mica por óxidos/hidróxidos de Fe. MEV/BSD.

O óxido/hidróxido de Fe também age como cimento entre grãos de todas as composiçōes, piorando sobremaneira a sua liberação, como pode ser observado na imagem da Figura 4.73. 


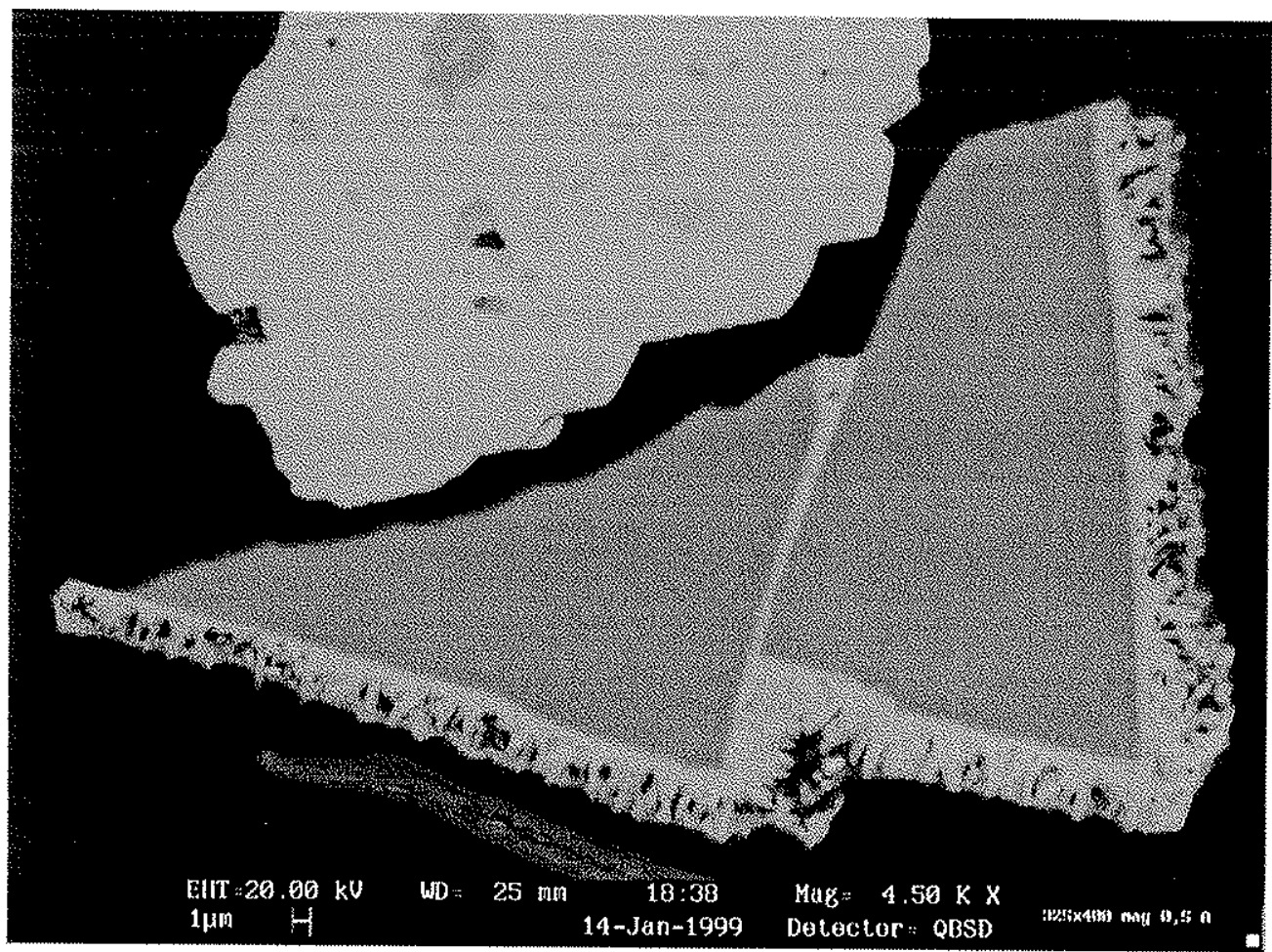

Figura 4.73 - Cristais de apatita soldados por óxido/hidróxido de Fe, formando cristais aciculares. MEV/BSD. 


\section{Análise de Imagens}

A Tabela 4.50 apresenta o teor de ponto, linha e área de monazita do minério laterítico, como obtido pela análise das imagens. Apresenta também o teor de cabeça composto, em volume e massa, considerando as frações analisadas (de 105 a $20 \mu \mathrm{m}$ ) fechando em $100 \%$, ou seja, desprezando os finos, e uma estimativa de composição química da cabeça composta, considerando-se a composição estequiométrica da monazita ( 1 de monazita $=0,6 \mathrm{TR}_{2} \mathrm{O}_{3}$ ), agora incluindo os finos no balanço, com o teor de $12,38 \%$ de $\mathrm{TR}_{2} \mathrm{O}_{3}$, obtido por análise química. Para cálculo de volume para massa foram utilizadas as densidades 5,20 para monazita e 3,50 para a ganga. Esses cálculos servem basicamente para verificar se os procedimentos de análise de imagem introduziram algum erro grotesco, como segmentação errada ou eliminação de partes importantes da monazita, que teria como conseqüência um teor de monazita muito diferente do verificado pela análise química.

Tabela 4.50 - Teores de monazita de ponto, linha e área, medidos por análise de imagens, cabeça composta de monazita desconsiderando a fração fina, $-20 \mu \mathrm{m}$, e teor de $\mathrm{TR}_{2} \mathrm{O}_{3}$ de cabeça calculado a partir da monazita e da análise química da fração fina, $-20 \mu \mathrm{m}$.

\begin{tabular}{lccr|rrr} 
& \multicolumn{3}{c|}{ Volume (\%) } & \multicolumn{3}{c}{ Massa (\%) } \\
\hline Fração $(\mu \mathrm{m})$ & Pixel & Linear & Área & Pixel & Linear & Area \\
\hline $105 \times 74$ & 2,78 & 2,83 & 2,7 & 4,08 & 4,15 & 3,96 \\
$74 \times 53$ & 2,55 & 2,47 & 2,54 & 3,74 & 3,63 & 3,73 \\
$53 \times 44$ & 3,18 & 3,11 & 3,25 & 4,65 & 4,55 & 4,75 \\
$44 \times 37$ & 4,49 & 4,53 & 4,53 & 6,53 & 6,59 & 6,59 \\
$37 \times 20$ & 6,57 & 6,44 & 6,17 & 9,46 & 9,28 & 8,90 \\
\hline Composto & 3,98 & 3,92 & 3,87 & 5,78 & 5,70 & 5,62 \\
\hline TR $_{2} \mathrm{O}_{3}$ calculado + finos AQ (\% massa) & 7,35 & 7,32 & 7,29 \\
\hline
\end{tabular}

Observa-se que há uma coerência muito boa entre os resultados de teores de ponto, linha e área em todas as medidas, como já era esperado. No caso do minério 
laterítico o teor de $\mathrm{TR}_{2} \mathrm{O}_{3}$ calculado a partir da monazita avaliada pela análise de imagens, e com balanço metalúrgico fechado com a análise química dos finos, difere em mais de $1 \%$ do teor de cabeça desse minério obtido por análises químicas convencionais, de $8,39 \%$, representando uma diferença de $12 \%$, aproximadamente. Parte dessa diferença deve ser devida aos outros carreadores de ETR, particularmente apatita, que não foi quantificada pela análise de imagem. Considerando-se, no entanto, que o teor médio de ETR medido nas apatitas é de 1,2\%, e que apatita certamente não perfaz mais de $80 \%$ do minério, uma parcela dessa diferença pode ser devida ao processamento das imagens, uma vez que há uma certa superposição dos picos de monazita com os de óxidos de $\mathrm{Fe}$, nos histogramas utilizados para segmentação. A perda de monazita foi preferida à sua super-estimativa, uma vez que incluir os óxidos de Fe nos procedimentos de cálculo de espectro de liberação da monazita certamente incluiria uma textura muito diferente daquela da monazita, e poderia comprometer todo o procedimento.

A liberação linear aparente, obtida pela análise de imagens das 5 frações granulométricas do minério laterítico, está representada graficamente na Figura 4.74. Pela análise desse gráfico observa-se que os interceptos apenas de ganga perfazem mais de $80 \%$ em todas as classes granulométricas, e que para as partículas maiores do que $37 \mu \mathrm{m}$ são $90 \%$ ou mais. 


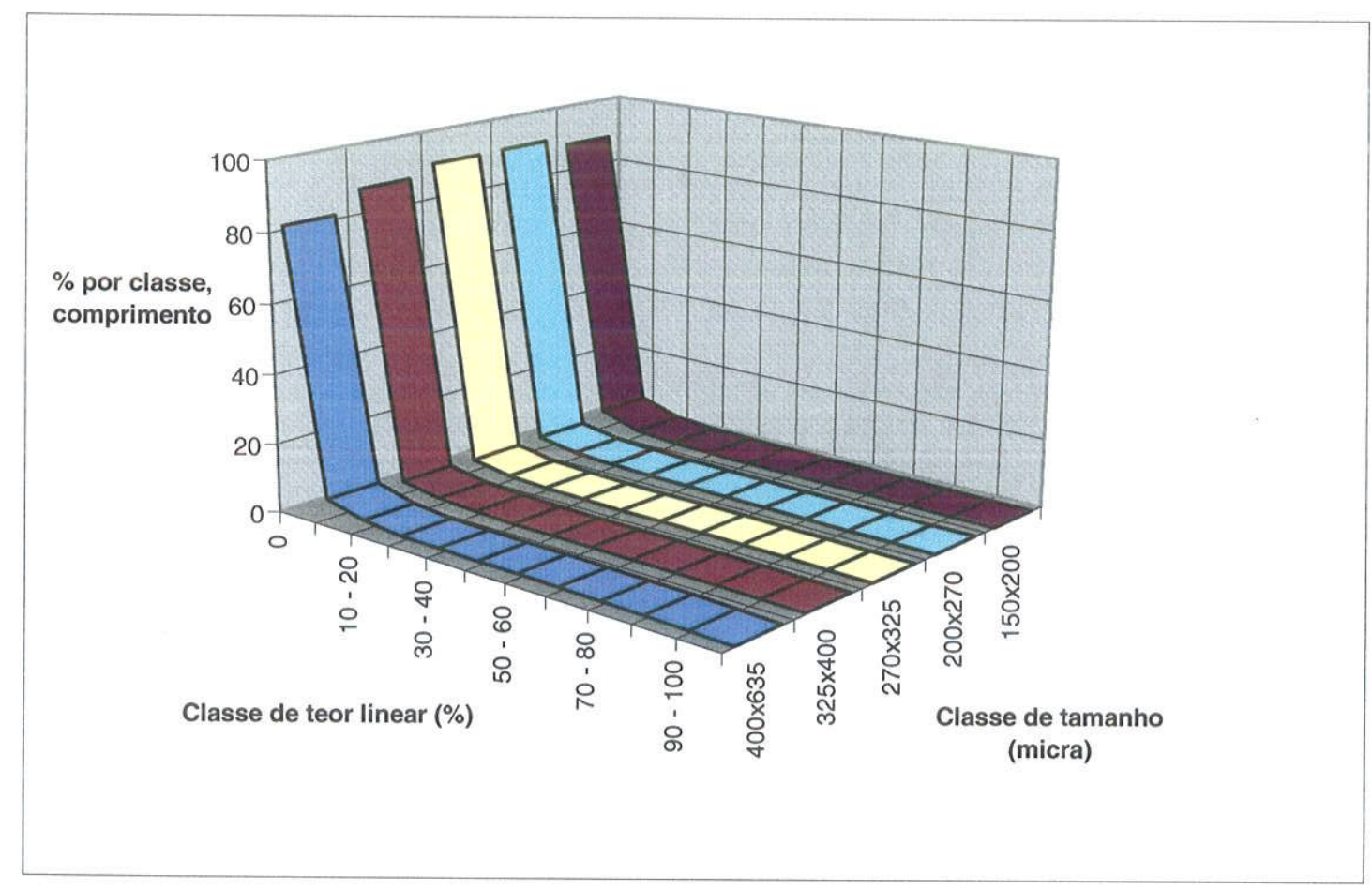

Figura 4.74 - Liberação linear aparente do minério laterítico, obtida pela análise de imagens. Condicional por tamanho.

Pela observação do diagrama de liberação em área aparente da Figura 4.75, pode ser observado que a liberação da monazita de sua ganga é má, mas que a ganga também não está liberada da monazita. A liberação da ganga em relação à monazita, no entanto, melhora visualmente com o decréscimo da granulometria, não atingindo, no entanto, boa liberação. 


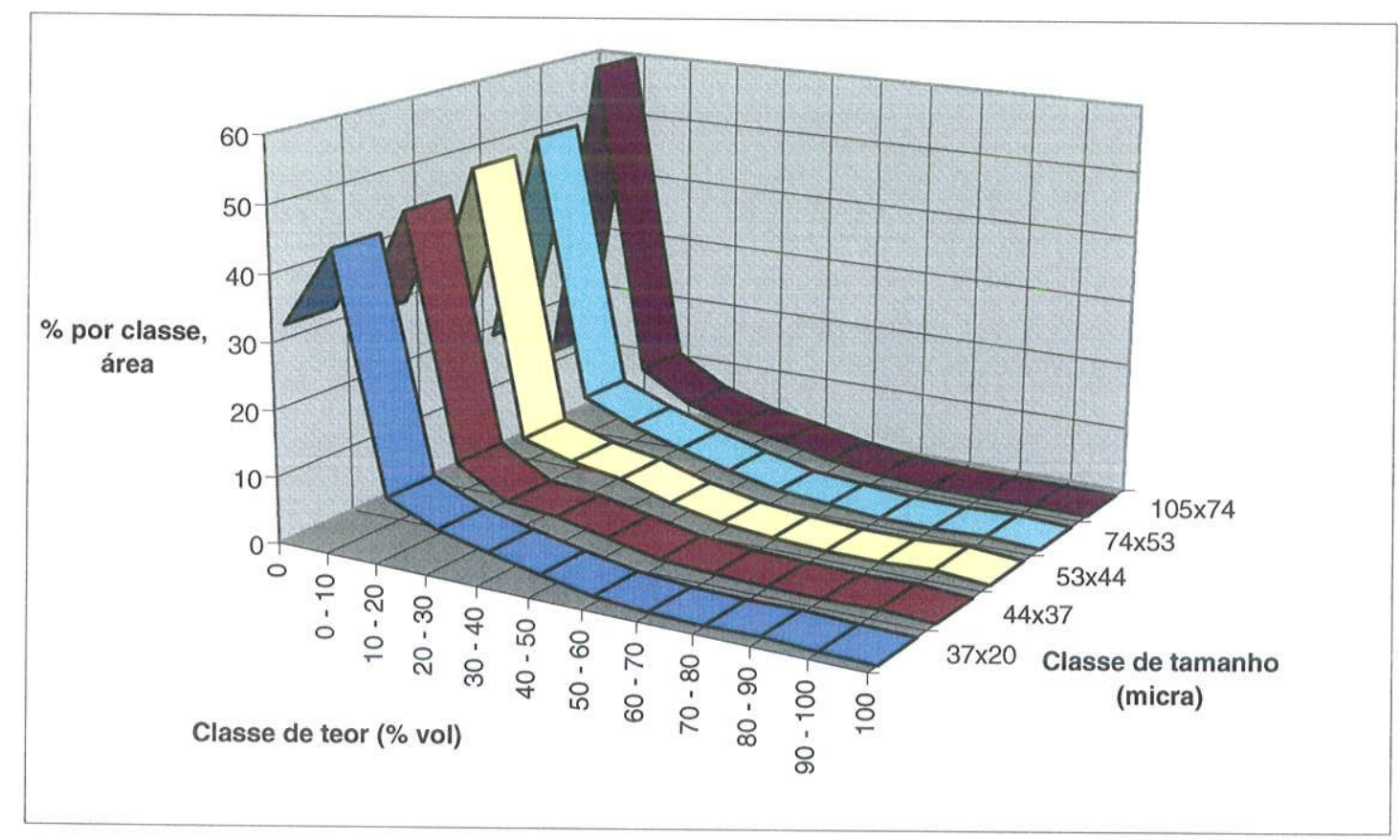

Figura 4.75 - Liberação em área aparente do minério laterítico, obtida pela análise de imagens. Condicional por tamanho.

A inversão estereológica foi processada a partir dos dados de liberação linear aparente, e não da liberação em área, por razões já arroladas anteriormente.

A análise das L-curves de Hansen plotadas com os dados do minério silexítico mostra que todas as frações têm resultado melhor quando a inversão estereológica é processada com função desenvolvida para dolomita/esfalerita alta resolução. A Figura 4.76 exemplifica a seleção da função de transformação pelo diagrama de Hansen, no caso para a fração mais fina, $37 \times 20 \mu \mathrm{m}$. 
cat2 $400 \times 635$ lib

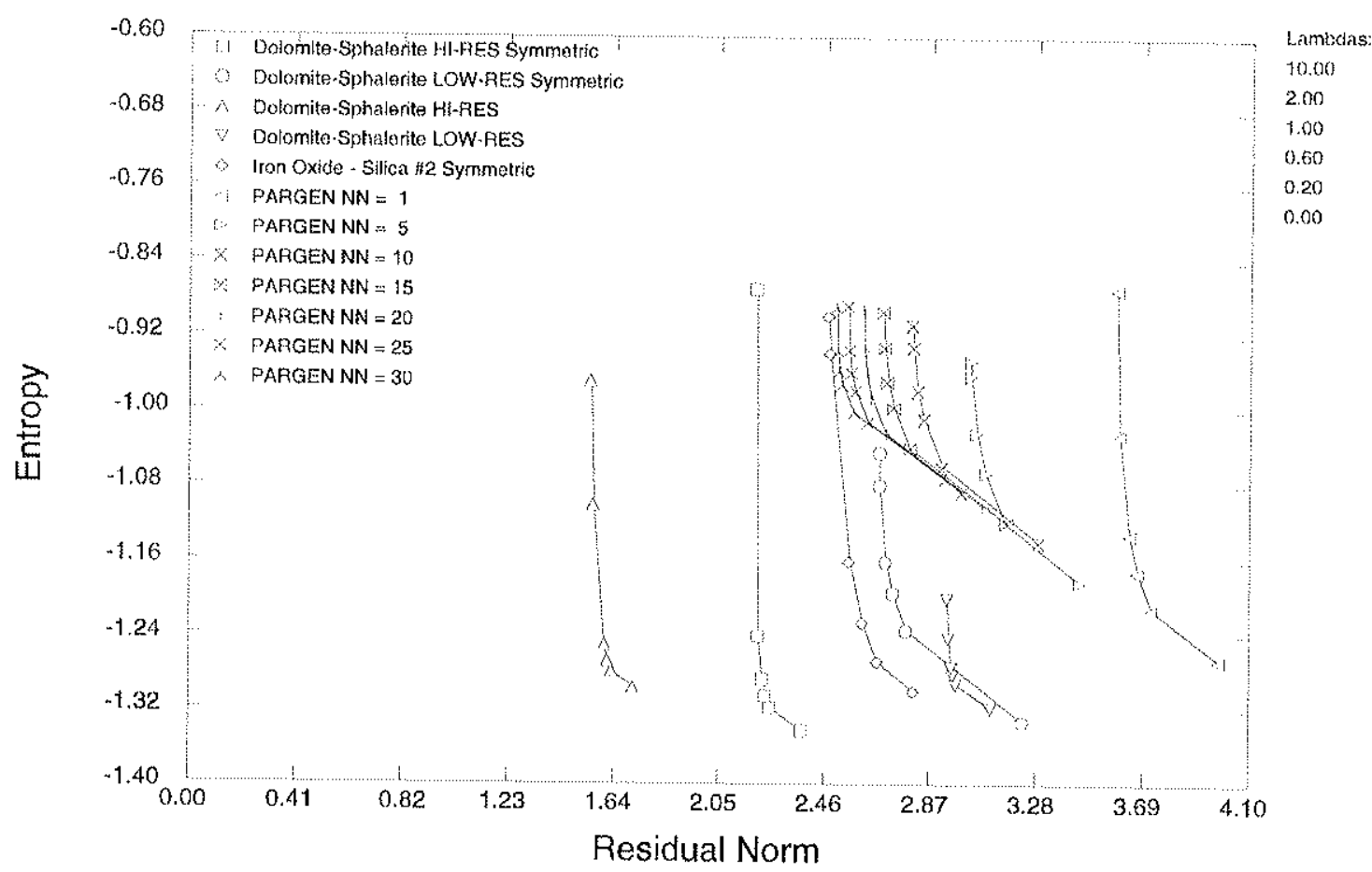

Figura 4.76 - L- curve de Hansen para os dados de intercepto linear obtidos por análise de imagem para a fração mais fina do minério laterítico, $37 \times 20 \mu \mathrm{m}$, onde se observa que a função de transformação dolomita-esfalerita alta resolução apresenta o menor resíduo e um módulo da entropia muito similar às curvas, de resíduo muito superior.

A partir da função de transformação selecionada, os dados de liberaçäo linear aparente puderam ser invertidos para liberação em volume, representada pelo diagrama da Figura 4.77. 


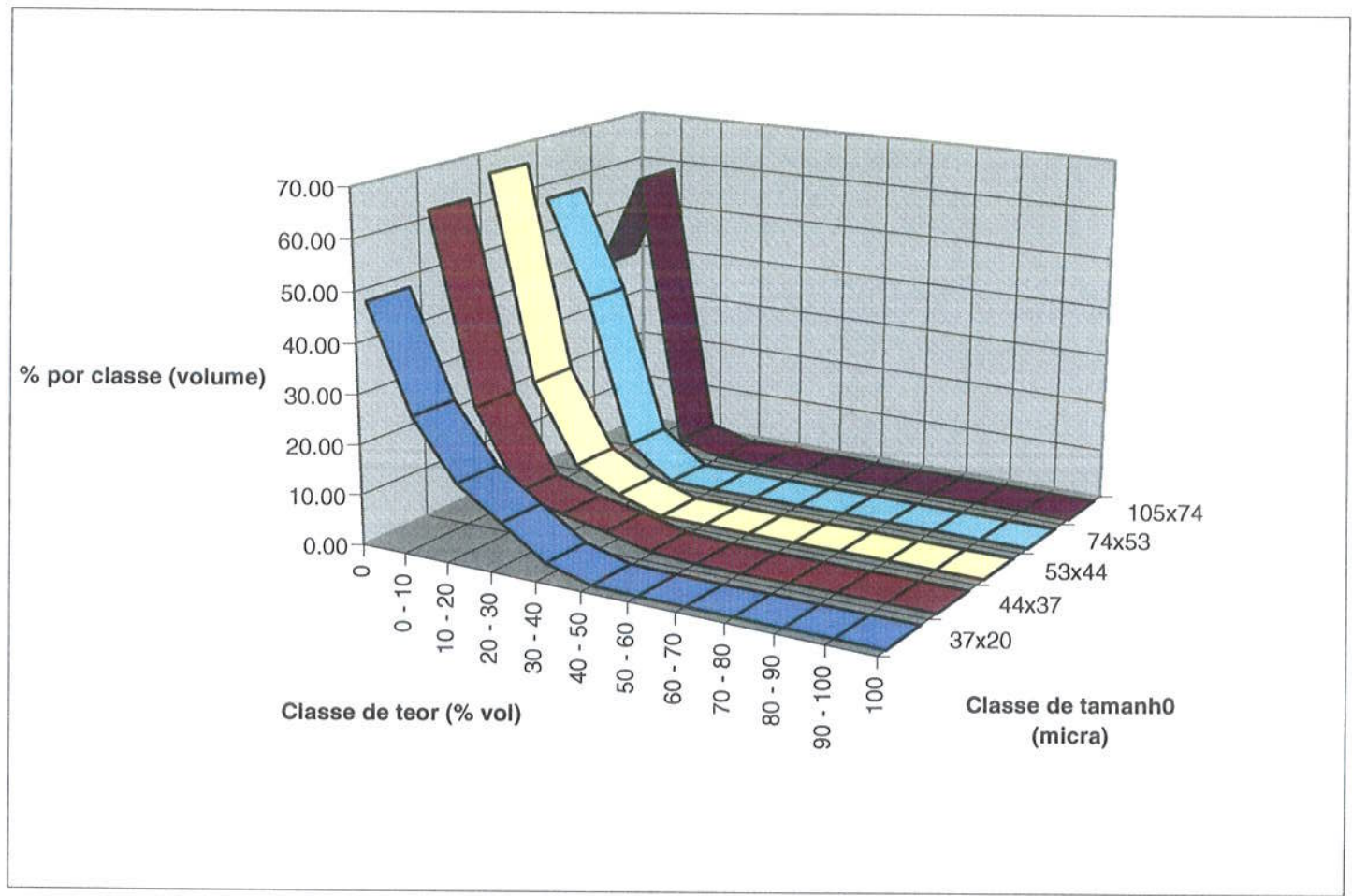

Figura 4.77 - Liberação em volume do minério laterítico, obtida pela análise de imagens, após correção estereológica. Condicional por tamanho.

Finalmente, o diagrama da Figura 4.78 apresenta os mesmos dados recalculados para massa, a partir das densidades presumidas para monazita e ganga (respectivamente 5,20 e 3,50). 


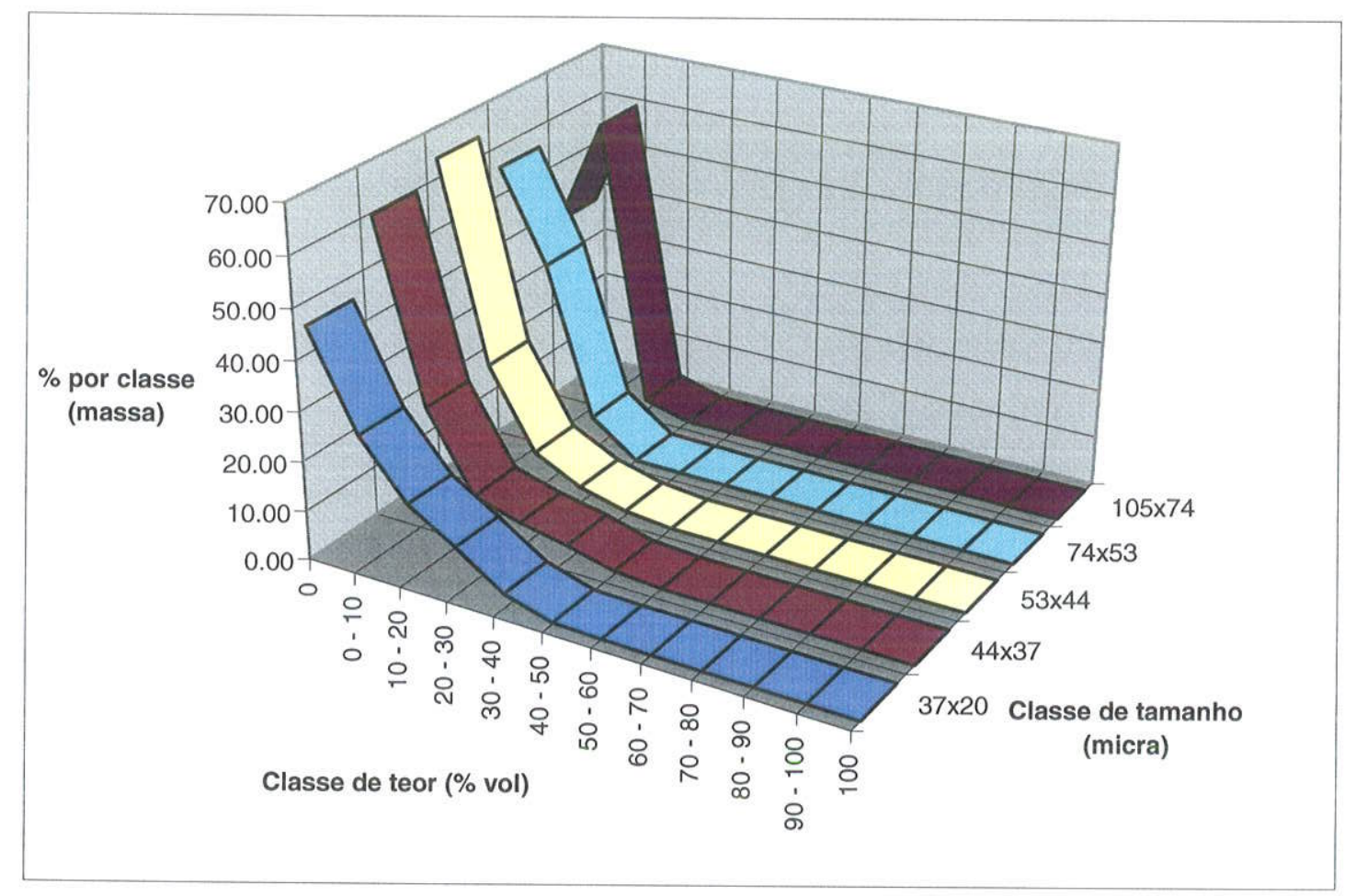

Figura 4.78 - Liberação em massa do minério laterítico, obtida pela análise de imagens, após correção estereológica. Condicional por tamanho.

A correção estereológica modificou profundamente os espectros de liberação aparente. A não-liberação da ganga foi minimizada, e apenas na fração mais grossa as partículas não liberadas de ganga superam as liberadas. Como a função utilizada para transformação desses dados foi a mesma para todos os tamanhos de partícula, a função efetuou as correções utilizando as informações contidas na distribuição de interceptos lineares.

O diagrama que representa a distribuição bivariada de tamanho e teor, ou de liberação natural da monazita no minério laterítico, está na Figura 4.79. Representa graficamente quanto da amostra de cabeça, em massa, tem determinado teor e tamanho de partícula. A liberação em massa da fração fina foi assumida como sendo igual à da fração mais próxima a ela, 37x20 $\mu \mathrm{m}$. 


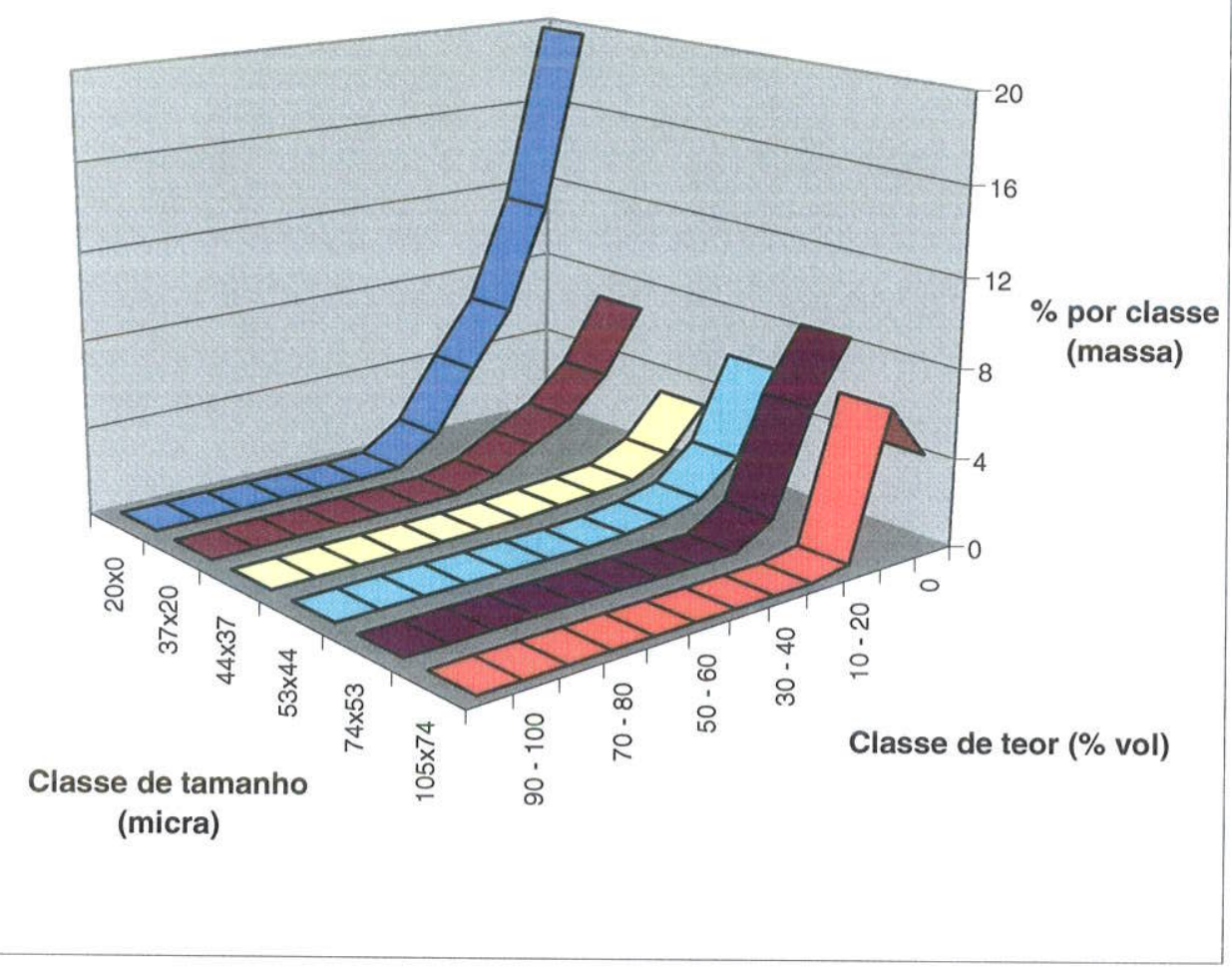

Figura 4.79- Espectro de liberação natural, em massa, do minério laterítico. Distribuição bivariada teor/tamanho. Liberação em massa condicional por tamanho da fração mais fina $(-20 \mu \mathrm{m})$ igual à da fração granulométrica mais próxima (37x20 $\mu \mathrm{m})$.

A influência da distribuição de tamanho de partículas fica clara com a grande quantidade de partículas exclusivamente de ganga, na fração mais fina, que advém, além da distribuição condicional por tamanho da fração, da grande quantidade de finos no minério, $43,52 \%$.

Mais uma vez a liberação da monazita absolutamente não foi atingida até $20 \mu \mathrm{m}$, e a extrapolação da distribuição condicional por tamanho da fração 37x20 para os finos deve estar introduzindo uma imprecisão grande nos cálculos de liberação, uma vez que a referida distribuição condicional não prevê partículas com mais de 50\% de monazita, que obviamente devem ocorrer em algum tamanho, mesmo que muito menor. $\mathrm{E}$ mais uma vez os problemas muito grandes para medir a liberação de partículas mais finas podem ser citados: é quase impossível obter uma fração granulométrica com faixa de 
tamanho de partícula estreita e bem definida abaixo de $20 \mu \mathrm{m}$; o embutimento das partículas nessas frações, supondo-se que puderam ser geradas dentro das especificações severas necessárias, seria muito difícil, uma vez que sua molhabilidade não é boa; o foco das imagens obtidas ao MEV para aquisição automática não seria suficientemente bom para uma análise de imagem acurada, exigindo aquisição manual das imagens. Por fim, a utilidade de se prever liberação abaixo de $20 \mu \mathrm{m}$, onde a quase totalidade dos métodos de concentração não são mais eficientes, não justifica os enormes transtornos e as incertezas que o método gera.

Os gráficos das Figuras 4.80 a 4.82 são o produto final do cálculo de espectro de liberação pela análise de imagens. São os diagramas que correlacionam o teor de monazita esperado no concentrado, a recuperação de monazita nesse concentrado, e o descarte de massa no rejeito de uma operação de separação hipotética, onde se supõe separação perfeita.

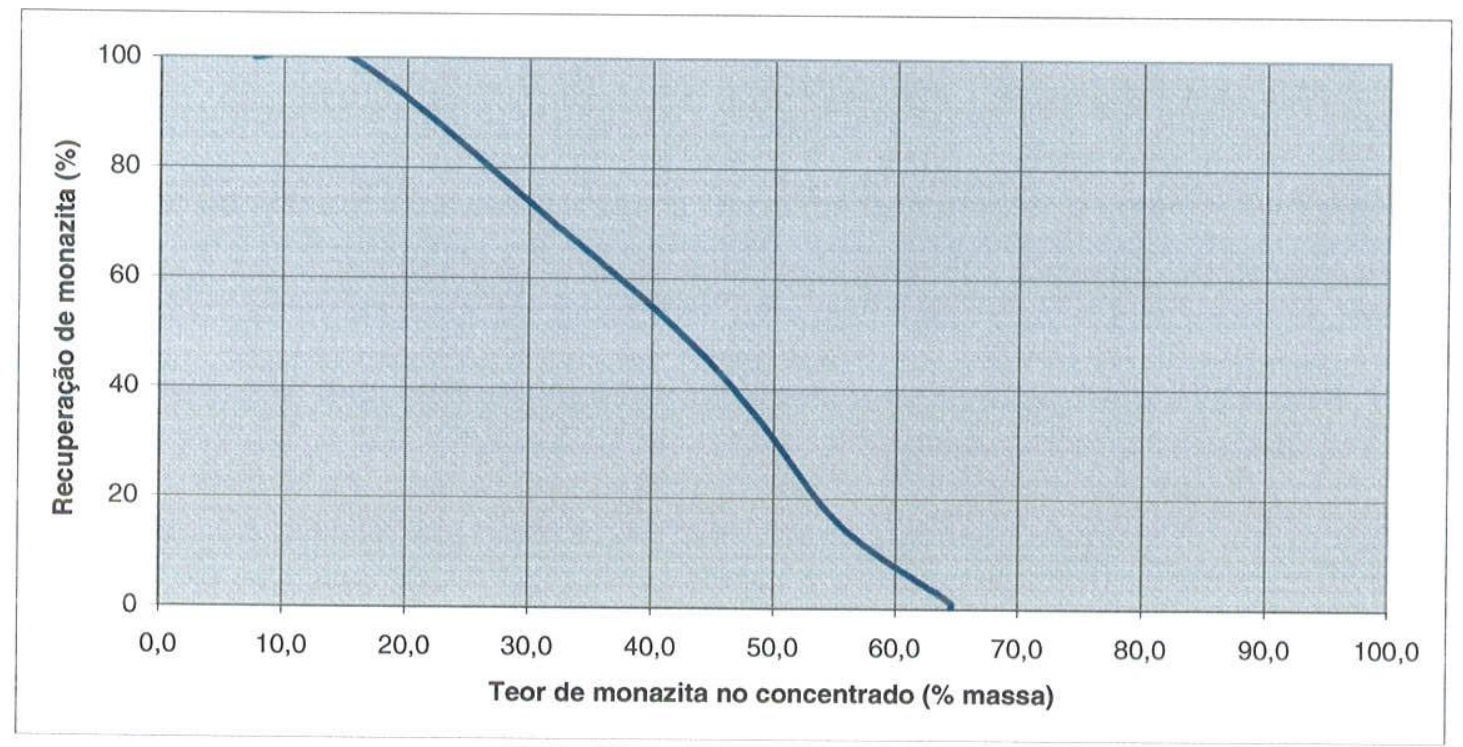

Figura 4.80 - Previsão de recuperação total da monazita em função do teor de monazita no concentrado. Minério laterítico. 


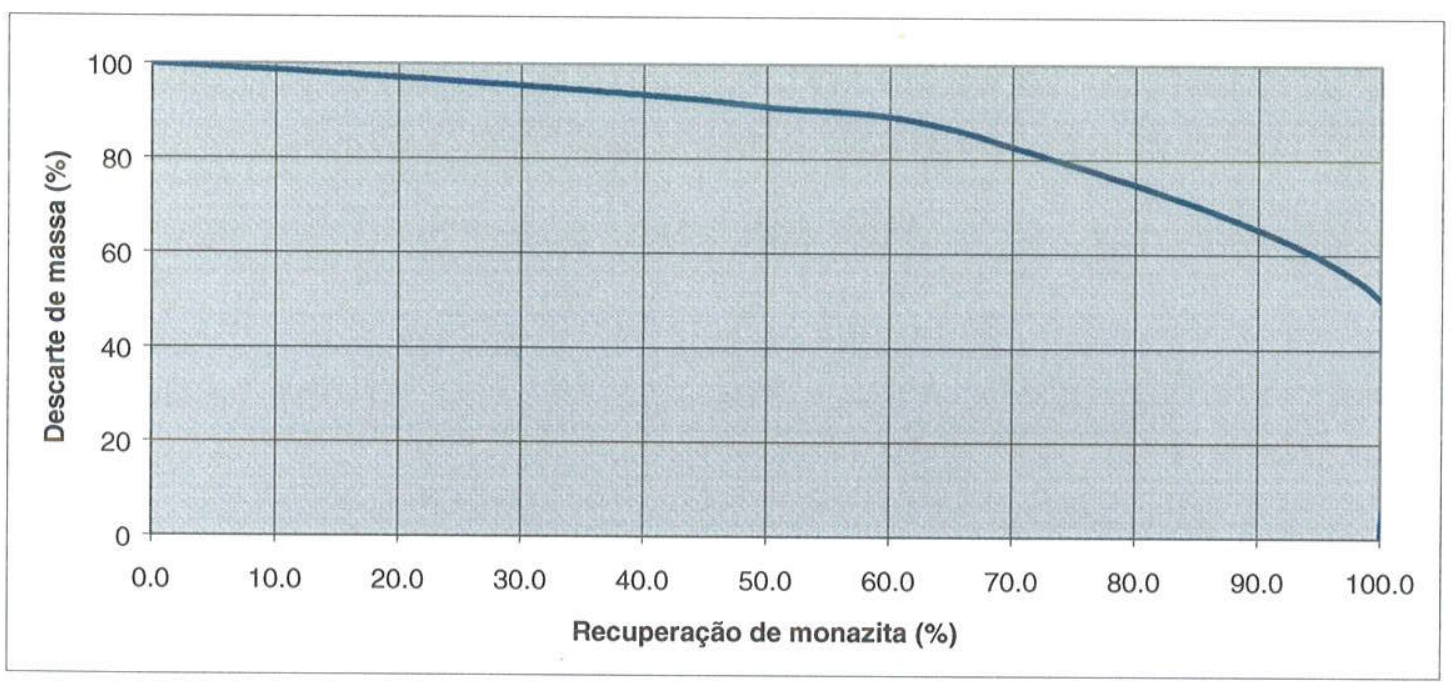

Figura 4.81 - Previsão de descarte de massa no rejeito em função da recuperação da monazita no concentrado. Minério laterítico.

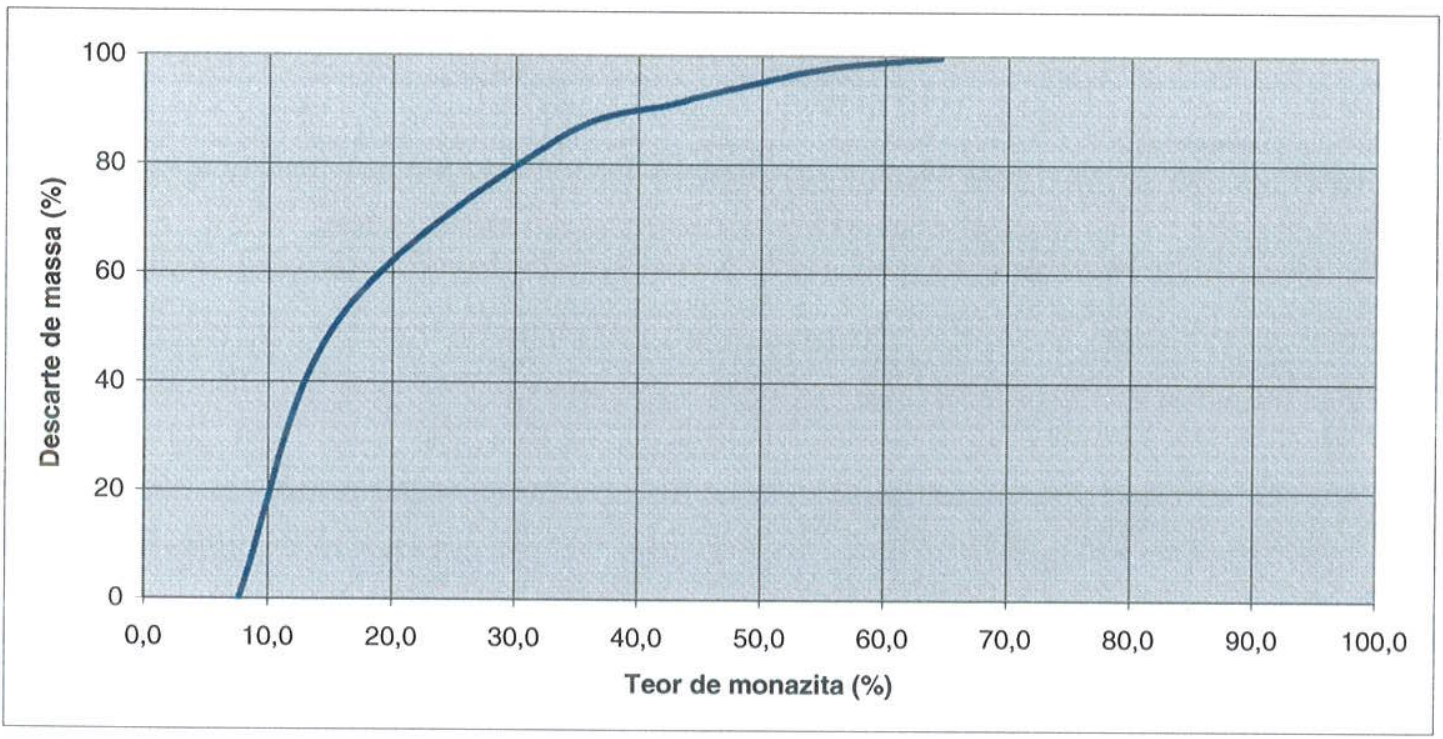

Figura 4.82 - Previsão de descarte de massa no rejeito em função do teor de monazita no concentrado. Minério laterítico.

O teor de monazita da amostra foi calculado em 7,62\%, utilizando-se a soma de todos os teores projetados, em massa (calculada multiplicando o teor em volume pela média em massa do teor da classe), para todas as classes de teor/tamanho. Do diagrama da Figura 4.80 depreende-se que o teor de monazita num eventual concentrado pode variar de 7,62\% até aproximadamente $65 \%$. Observa-se na Figura 
4.81 que é possível descartar $50 \%$ da massa, aproximadamente, sem perdas de monazita. Isso advém do fato de aproximadamente $50 \%$ das partículas estarem na classe de teor 0 , ou seja, ganga liberada, como pode ser observado nos dados de liberação bivariante da Figura 4.79. Dessa forma, o descarte de $50 \%$ da massa poderia promover um incremento de teor de 7,6 a $15,4 \%$ de monazita, sem nenhuma perda. A partir de então, qualquer melhoria no teor do concentrado, e consequentemente descarte de massa adicional, promove uma menor recuperação da monazita no concentrado. A título de exemplo, um concentrado contendo em torno de $50 \%$ de monazita, ainda muito inferior ao obtido atualmente a partir de areias de praias ou cordöes litorâneos, acarretaria numa recuperação de pouco mais de $30 \%$ do total dos OTR, mas permitiria um descarte de massa da ordem de $95 \%$. A mesma relação também pode ser observada no diagrama 4.81. Por outro lado, se for desejado uma recuperação de, por exemplo, $70 \%$ da monazita, isso significa um descarte de pouco mais de $80 \%$ da massa, e um teor de monazita no concentrado inferior a $35 \%$. Essas projeções quantificam a péssima liberação da monazita e a traduzem para os parâmetros de eventual processo. 


\section{Minério Carbonatítico}

As análises do minério carbonatítico, por uma questão inclusive de representatividade da amostra, restringem-se a uma difração de raios $X$, uma análise do segmento embutido e polido ao MEV/EDS e à previsão de liberação por análise de imagem.

A amostra de carbonatito analisada contém $6,64 \%$ de $\mathrm{TR}_{2} \mathrm{O}_{3}$ e $3,56 \%$ de $\mathrm{Fe}_{2} \mathrm{O}_{3}$.

A assembléia mineralógica identificada por difração de raios $X$ é magnesita, dolomita, monazita-Ce, estroncianita, clinoenstatita, pirita e isokita. Adicionalmente, ainda foram detectados, por MEV/EDS, galena, esfalerita, pirocloro, barita e ilmenita.

O único carreador de terras raras importante identificado nessa amostra é a monazita, uma vez que os carbonatos e a clinoenstatita não acusaram esses elementos.

De um ponto de vista geral, a monazita mantém no minério carbonatítico uma característica que também apresenta nos outros dois tipos de minérios: é fina, mas apresenta aglomerados desses fragmentos mais finos gerando concentrações maiores. Essa propriedade the confere uma textura que varia com a escala de observação, como poderá ser quantificado mais à frente. A monazita geralmente se apresenta em secções hexagonais, e com certa freqüência oca na direção do maior eixo do prisma, que the confere a aparência de canaleta quando seccionado ao longo, como pode ser observado nas imagens das Figuras 4.83 e 4.84 


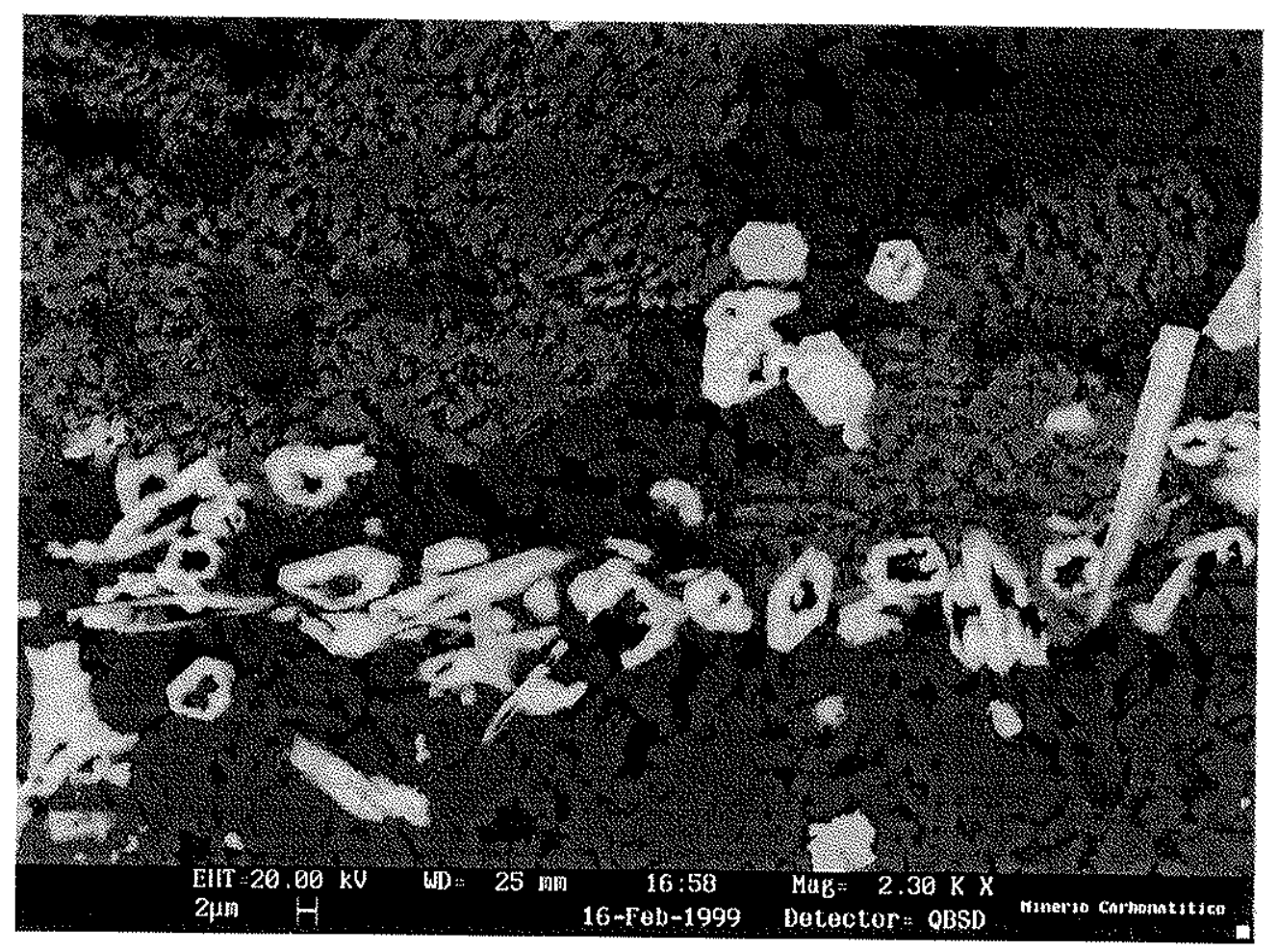

Figura 4.83 - Monazita de secção hexagonal e com um tubo interno, que the confere aspecto de calha ao ser seccionada (mais clara), sobre matriz carbonática de dolomita (cinza médio) e magnesita (cinza escuro). MEV/BSD.

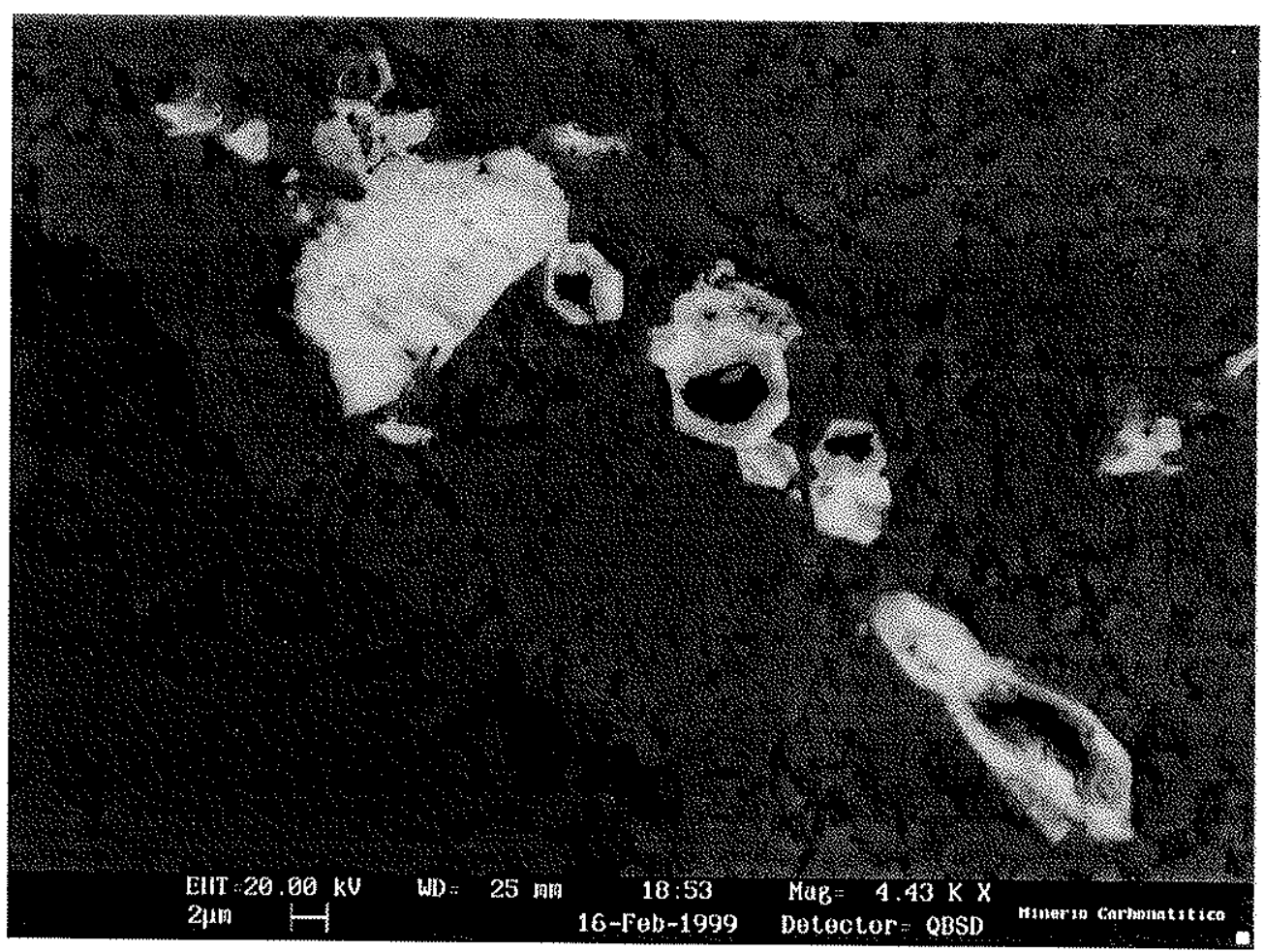

Figura 4.84 - Monazita de secção hexagonal (mais clara), sobre matriz carbonática de dolomita (cinza médio) e magnesita (cinza escuro). MEV/BSD. 
A monazita de secção hexagonal não havia sido observada anteriormente, mas uma feição similar e intermediária entre os hexágonos ocos vistos nas imagens acima e os esferóides concêntricos típicos do minério silexítico foram observados no carbonatito, como pode ser conferido na imagem da Figura 4.85. A semelhança é apenas morfológica, uma vez que os teores de Si nessas monazitas situam-se no limite de detecção do EDS utilizado.

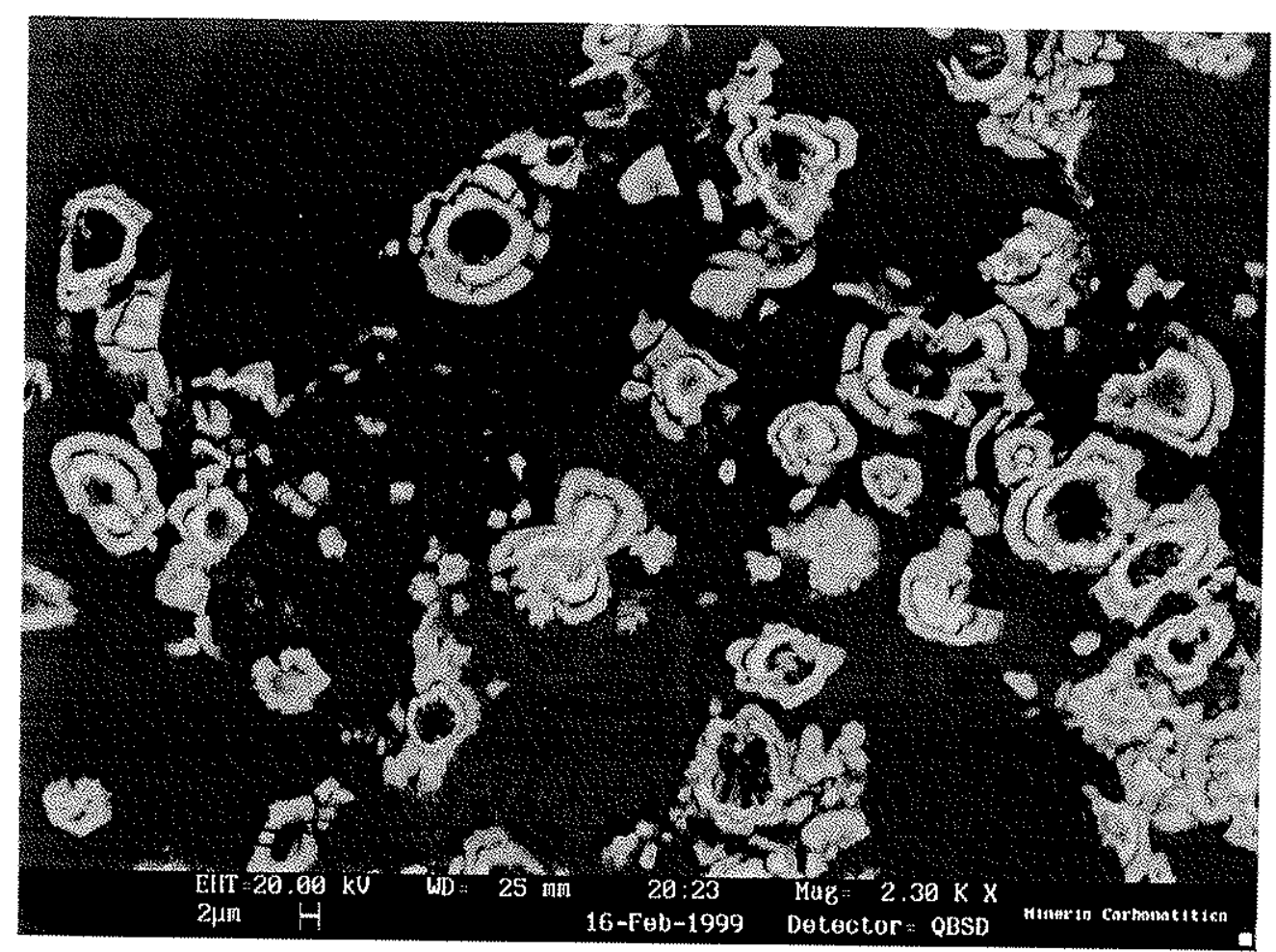

Figura 4.85 - Monazita esferoidal com niveis concêntricos (mais clara) e isokita esferoidal fibrosa (cinza médio), sobre matriz carbonática de dolomita (cinza médio), magnesita (cinza escuro rugoso) e clinoenstatita (cinza escuro liso). MEV/BSD.

Um grande aglomerado desses fragmentos e cristais de monazita finos, pode ser observado na Figura 4.86, em matriz de dolomita e magnesita. 


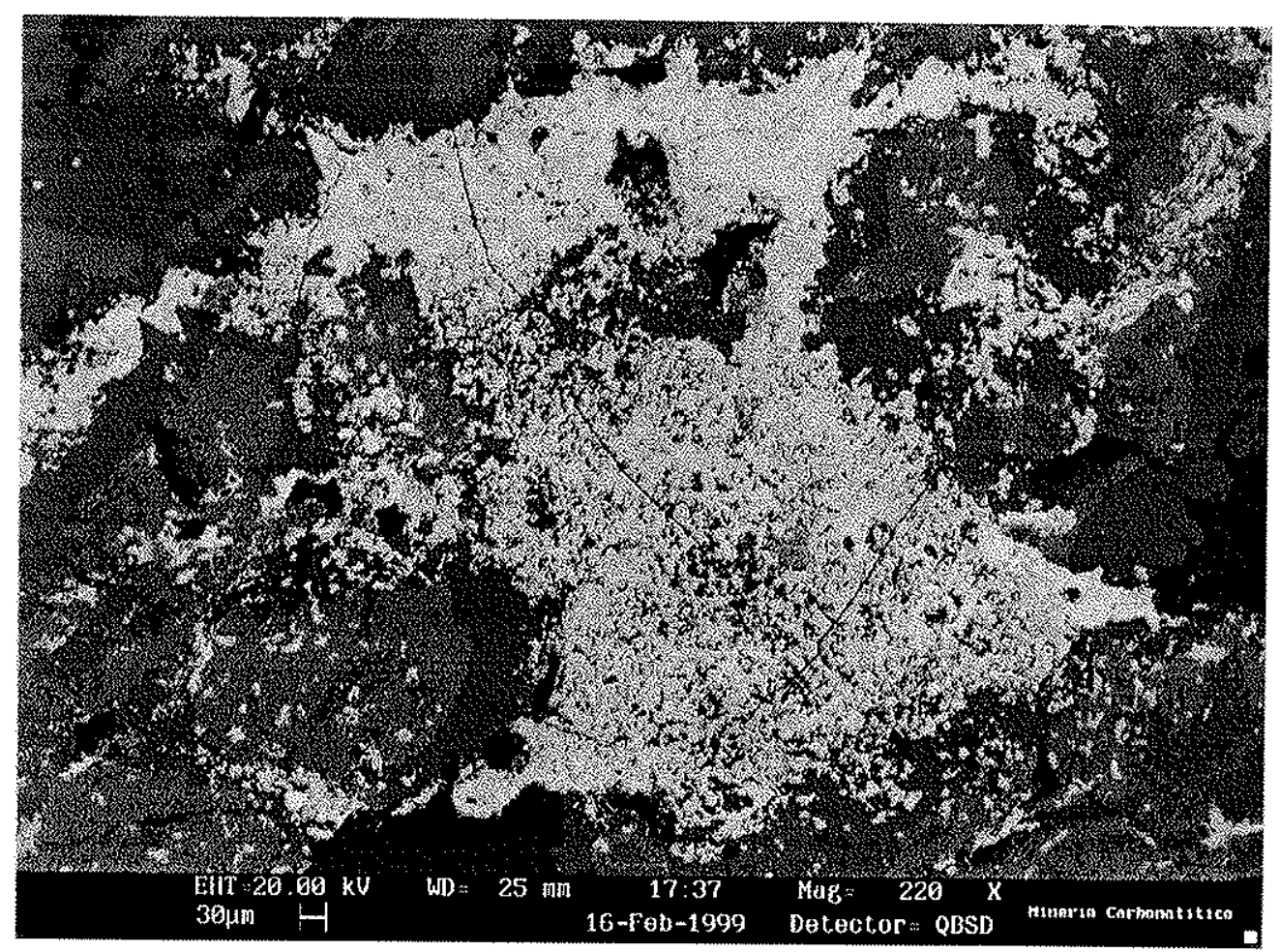

Figura 4.86 - Aglomerado de monazita (mais clara), sobre matriz carbonática de dolomita (cinza médio) e magnesita (cinza escuro). MEV/BSD.

Mais raramente a monazita pode ser vermiforme, como pode ser observado na imagem da Figura 4.87 


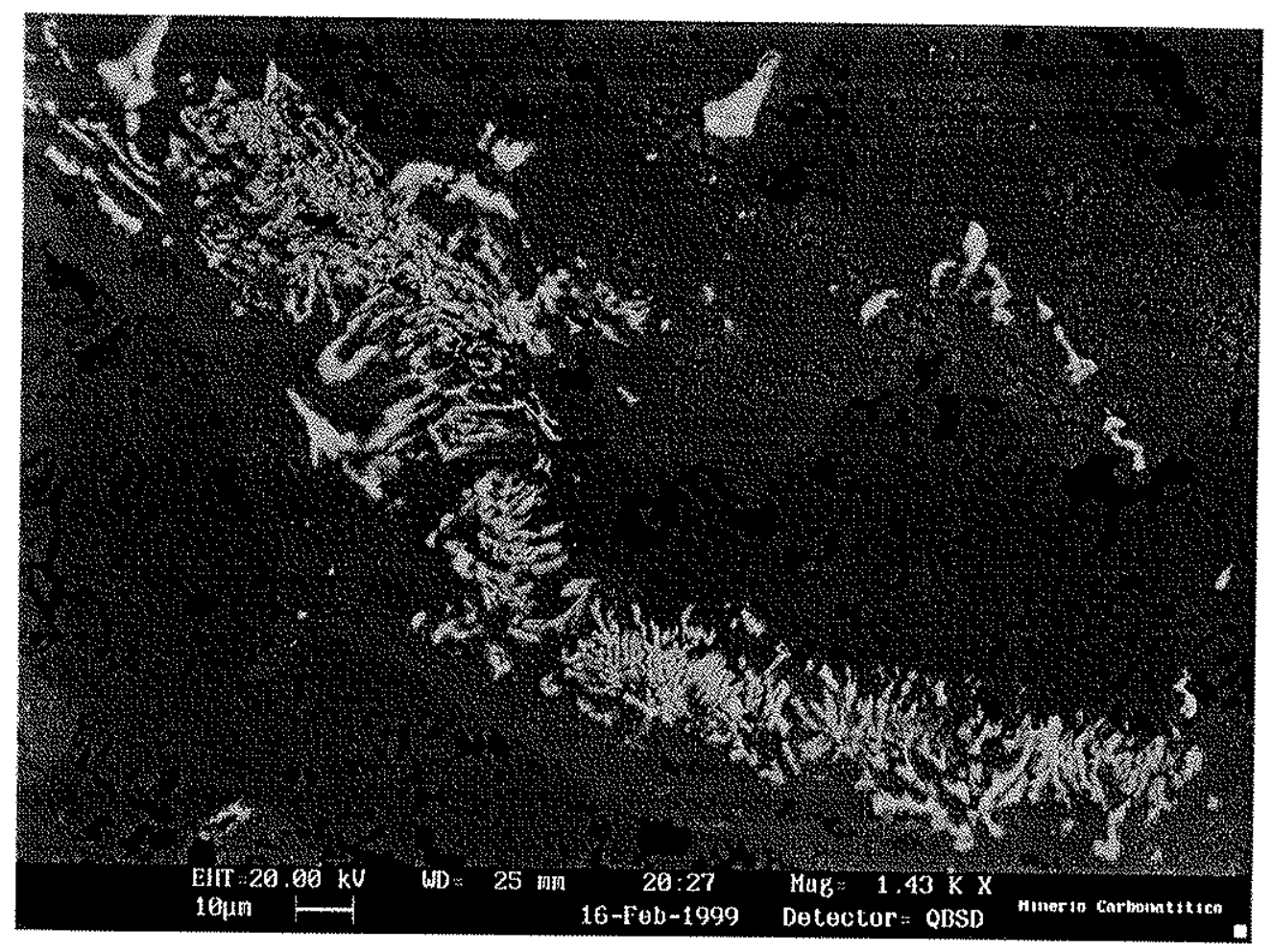

Figura 4.87 - Monazita vermiforme (mais clara), em dolomita (cinza médio) e magnesita (cinza escuro). MEV/BSD.

A composição da monazita no minério carbonatítico é muito semelhante à medida nos minérios silexítico e laterítico. A Tabela 4.51 fornece os dados obtidos por EDS em 8 fragmentos de monazita.

Tabela 4.51 - Composições químicas de monazitas no carbonatito. Medidas (EDS, \% em massa) recalculadas após subtração de Si. Média em negrito na última linha.

\begin{tabular}{|c|c|c|c|c|c|c|c|}
\hline $\mathrm{O}$ & $P$ & $\mathrm{Ca}$ & $\mathrm{Sr}$ & $\mathrm{La}$ & $\mathrm{Ce}$ & $\mathrm{Nd}$ & $\Sigma$ ETR \\
\hline 28,2 & 15,5 & 2,0 & 4,7 & 15,4 & 27,9 & 6,3 & 49,6 \\
\hline 26,7 & 16,3 & 2,1 & 4,5 & 15,0 & 28,3 & 7,0 & 50,4 \\
\hline 29,8 & 15,7 & 1,8 & 4,4 & 13,6 & 27,4 & 7,3 & 48,3 \\
\hline 29,7 & 15,1 & 2,0 & 4,6 & 13,1 & 27,6 & 7,9 & 48,5 \\
\hline 28,4 & 15,1 & 1,6 & 4,0 & 20,0 & 26,6 & 4,3 & 50,9 \\
\hline 30,1 & 15,1 & 1,6 & 4,7 & 19,4 & 25,0 & 4,2 & 48,5 \\
\hline 26,0 & 15,5 & 1,8 & 4,5 & 19,5 & 27,3 & 5,4 & 52,2 \\
\hline 29,5 & 15,2 & 1,9 & 4,7 & 17,6 & 26,3 & 4,8 & 48,7 \\
\hline 28,5 & 15,4 & 1,8 & 4,5 & 16,7 & 27,1 & 5,9 & 49,7 \\
\hline
\end{tabular}

Silício foi subtraído, mas nunca ultrapassou $0,1 \%$ (em massa, valores absolutos). O que se destaca nessas análises é o teor ainda mais alto, e estável, de Sr, 
cuja média de $4,5 \%$ do elemento está acima das médias de 3,3\% medidas no minério silexítico e $4,2 \%$ no laterítico.

Além de monazita, foi identificado apenas um cristal de pirocloro contendo alguma terra rara, retratado na imagem da Figura 4.88, e cuja análise está na Tabela 4.52. Apesar de ser apenas um cristal, o teor de óxidos de terras raras totais é elevado, $6,1 \%$, e coerente com as análises efetuadas em pirocloros no minério laterítico.

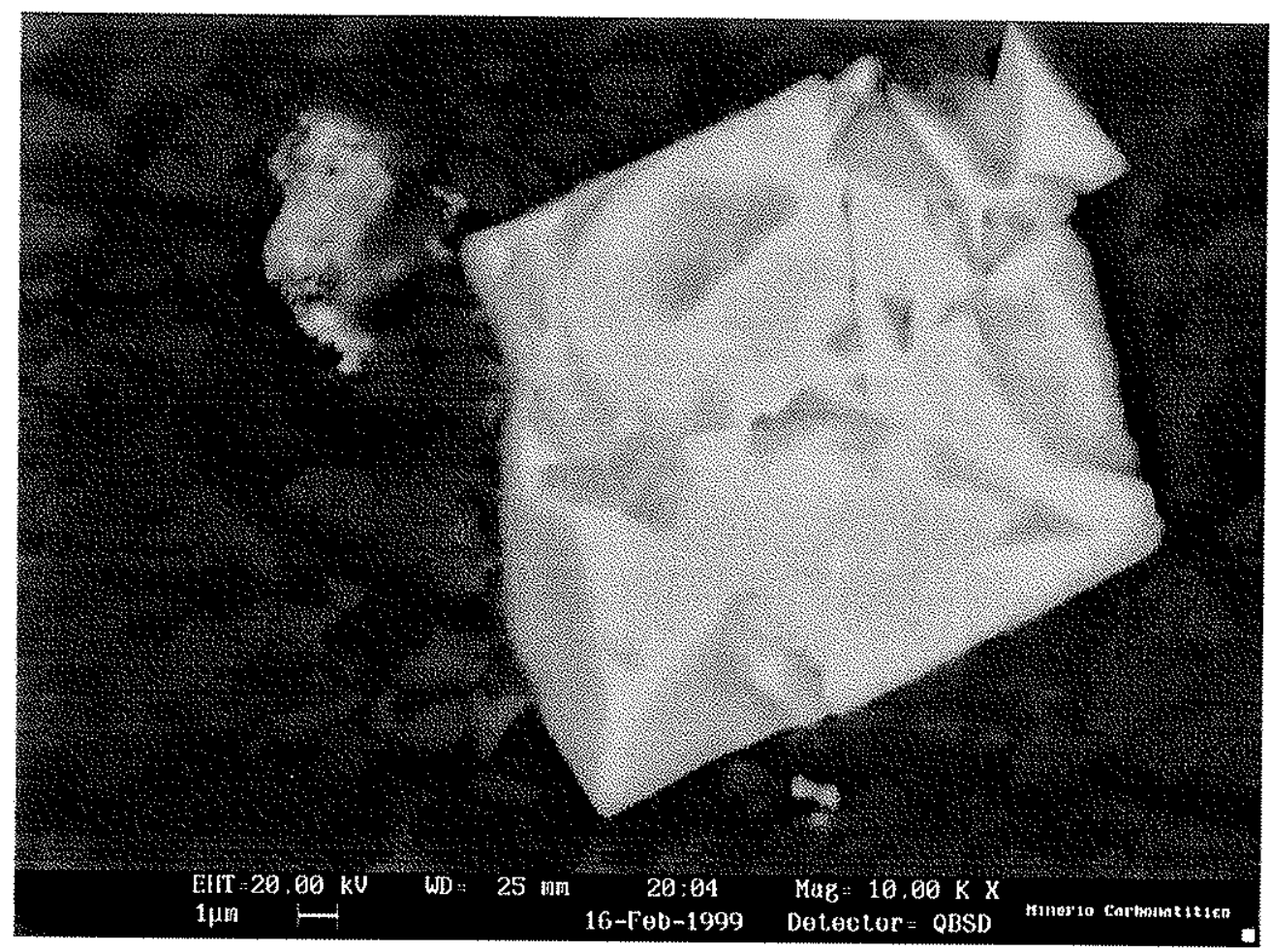

Figura 4.88 - Pirocloro em dolomita. MEV/BSD. 
Tabela 4.52 - Composição química do pirocloro da Figura 4.88 (EDS, \% massa).

\begin{tabular}{lc}
\hline $\mathrm{CaO}$ & 11,1 \\
$\mathrm{TiO}_{2}$ & 1,9 \\
$\mathrm{Fe}_{2} \mathrm{O}_{3}$ & 0,2 \\
$\mathrm{Nb}_{2} \mathrm{O}_{5}$ & 77,8 \\
$\mathrm{BaO}$ & 0,3 \\
$\mathrm{La}_{2} \mathrm{O}_{3}$ & 1,9 \\
$\mathrm{CeO}_{2}$ & 4,0 \\
$\mathrm{Nd}_{2} \mathrm{O}_{3}$ & 0,2 \\
$\mathrm{Ta}_{2} \mathrm{O}_{5}$ & 0,8 \\
$\mathrm{PbO}$ & 0,0 \\
$\mathrm{UO}$ & 0,2 \\
\hline$\Sigma \mathrm{OTR}$ & 6,1 \\
\hline Total & 98,5 \\
\hline
\end{tabular}

Os minerais de ganga mais importantes são magnesita e dolomita, que formam a matriz do carbonatito, além da clinoenstatita. Apesar de possíveis pelas especificações do detector, as análises de carbonatos por EDS sempre têm resultados muito ruins, ainda mais quando elementos mais pesados, como $\mathrm{Fe}$ e $\mathrm{Mn}$, estão presentes. Algumas análises, no entanto, são apresentadas na Tabela 4.53 e devem ser encaradas apenas como dados qualitativos. As análises de $\mathrm{C}$ foram suprimidas, uma vez que o recobrimento de carbono deve interferir na análises, e porque os resultados foram absurdos.

Tabela 4.53 - Composições químicas de alguns pontos de magnesita e dolomita. Análises qualitativas por EDS, \% em massa.

\begin{tabular}{cccccc}
\hline & Dolomita & Dolomita & Dolomita & Magnesita & Magnesita \\
\hline $\mathrm{Mg}$ & 11,2 & 8,7 & 10,3 & 25,7 & 24,9 \\
$\mathrm{Ca}$ & 18,5 & 18,5 & 18,7 & 0,2 & 0,1 \\
$\mathrm{Mn}$ & 0,4 & 0,6 & 0,4 & 0,6 & 0,4 \\
$\mathrm{Fe}$ & 0,6 & 0,5 & 0,6 & 0,7 & 0,6 \\
$\mathrm{Sr}$ & 0,5 & 0,7 & 0,9 & 0,0 & 0,1 \\
\hline
\end{tabular}

As composições são bem estáveis para esses elementos, e a maior variação ocorre no teor de $\mathrm{Mg}$ (e secundariamente de Sr) da dolomita. 
A estroncianita também ocorre como fase razoavelmente comum no carbonatito. Geralmente se apresenta como cristais grandes aparentemente corroídos, como pode ser visto na Figura 4.89, ou cristais menores (Figura 4.90), sempre associados aos outros carbonatos.

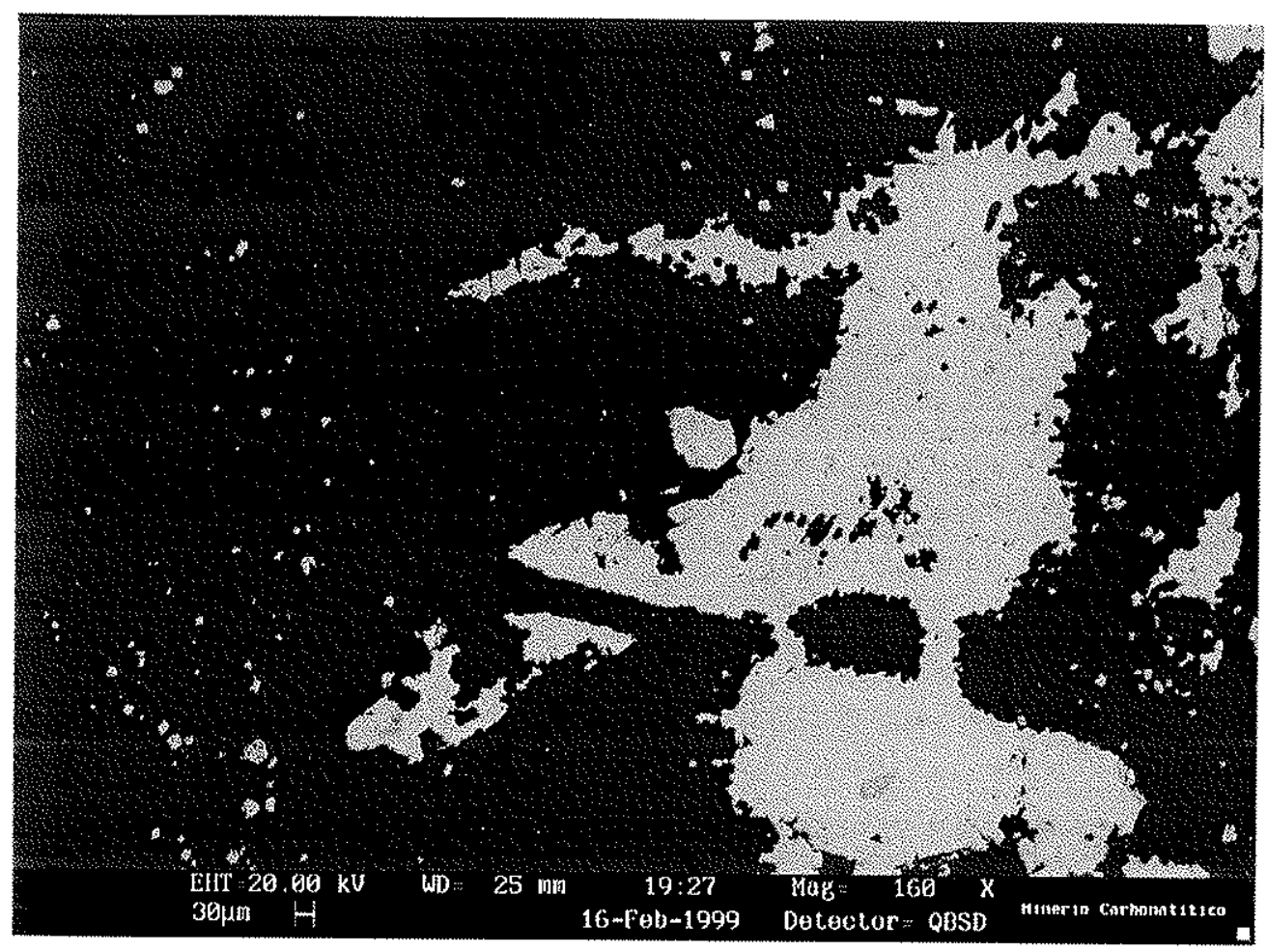

Figura 4.89 - Grande cristal de estroncianita (mais claro), aparentemente corroído, em matriz de magnesita. MEV/BSD. 


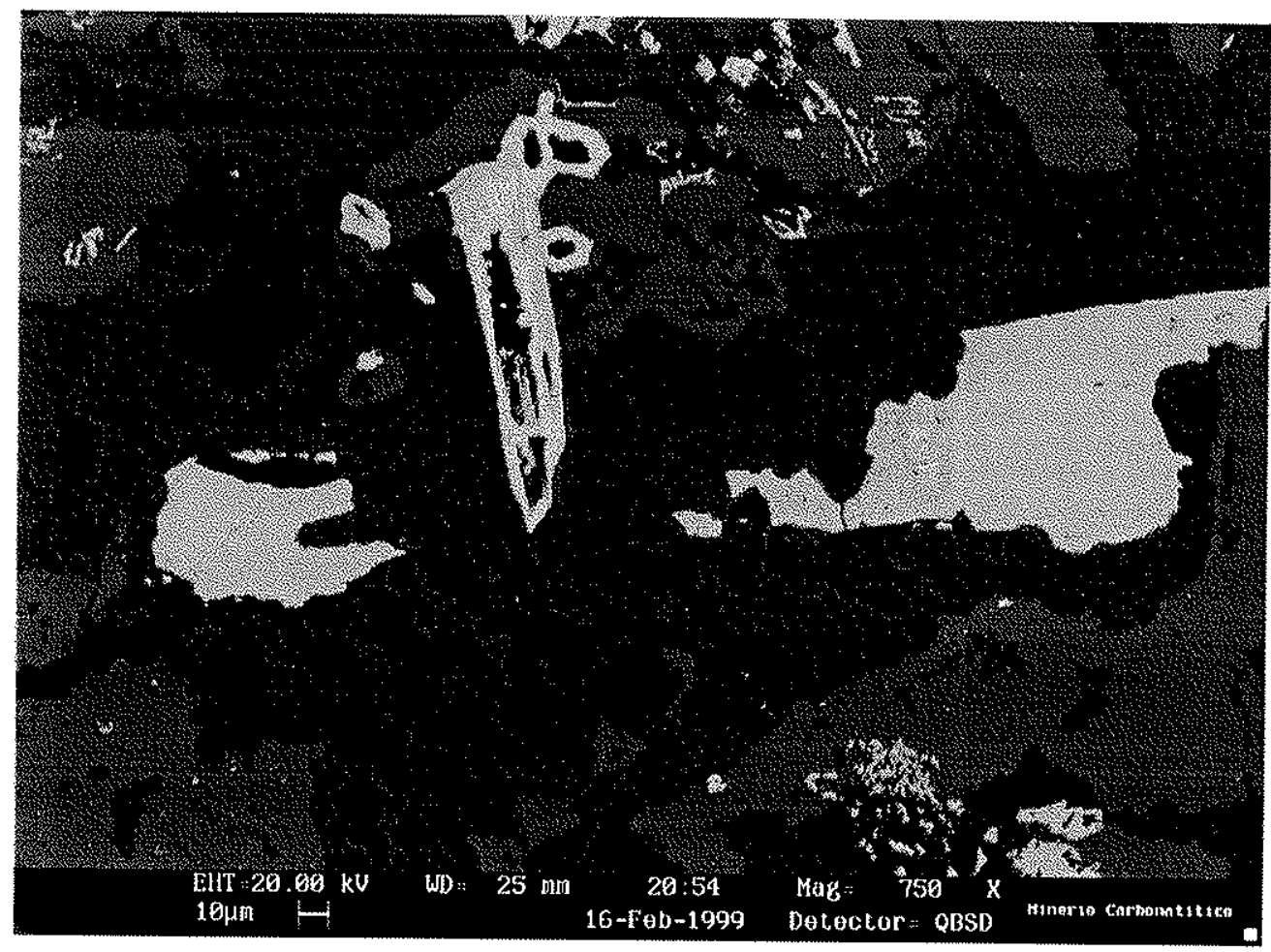

Figura 4.90 - Dois cristais de estroncianita (claros, meio à direita e à esquerda) com monazita hexagonal tubular (inclusive seccionada), em matriz de dolomita (cinza médio), magnesita (cinza escuro), além de monazita fina. MEV/BSD.

Algumas análises por EDS da estroncianita estão na Tabela 4.54. Assim como para magnesita e dolomita, náo são apresentados os resultados de carbono.

Tabela 4.54 - Análises qualitativas de estroncianita (EDS, \% em massa).

\begin{tabular}{lccc}
\hline $\mathrm{Mg}$ & 0,1 & 0,0 & 0,1 \\
$\mathrm{Ca}$ & 0,2 & 0,9 & 0,3 \\
$\mathrm{Mn}$ & 0,1 & 0,0 & 0,1 \\
$\mathrm{Fe}$ & 0,0 & 0,1 & 0,0 \\
$\mathrm{Sr}$ & 59,2 & 54,9 & 59,1 \\
\hline
\end{tabular}

Isokita foi observada com certa freqüência na amostra. Sempre é esferoidal e fibrosa, e geralmente as fibras estão dispostas radialmente (mas podem ocorrer feixes das fibras). As Figuras 4.91 a 4.93 mostram o hábito da isokita, e a Tabela 4.55 a sua composição, determinada por EDS. 


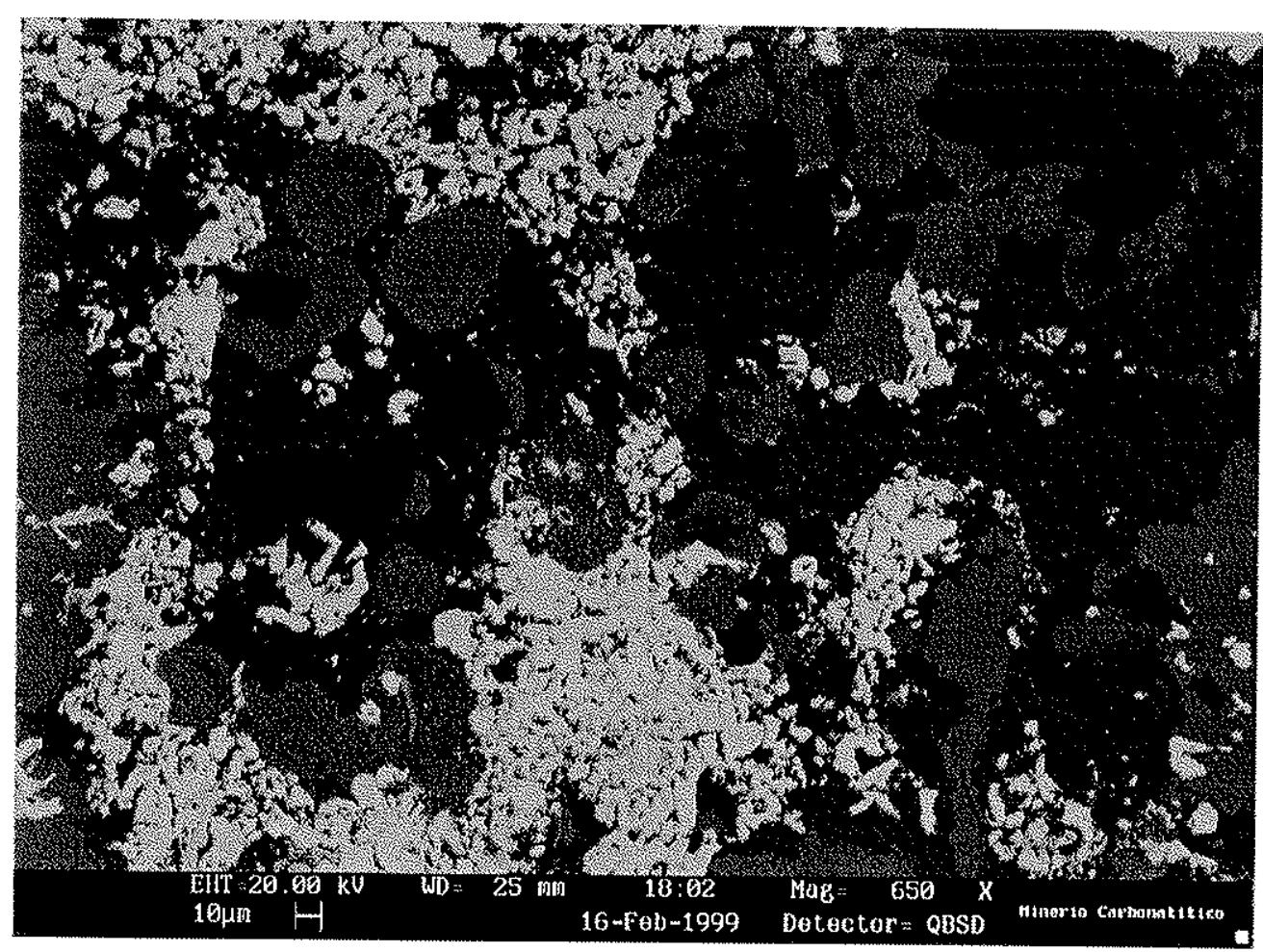

Figura 4.91 - Isokita esferoidal fibrosa associada a monazita (mais clara), clinoenstatita (mais escura, lisa) e dolomita (cinza médio, rugosa e não-esferoidal). MEV/BSD.

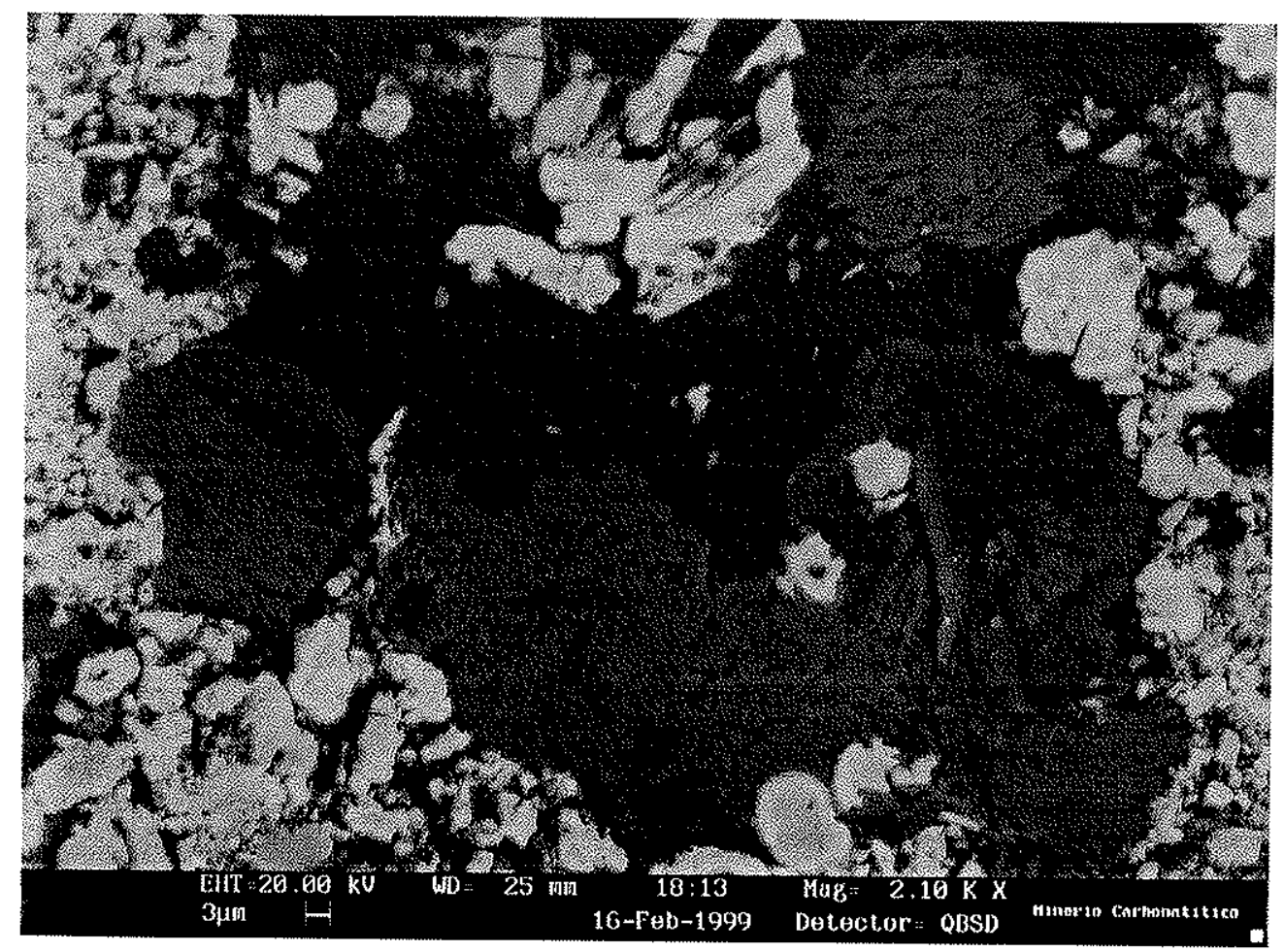

Figura 4.92 - Detalhe da figura anterior, onde é possivel reconhecer o caráter esferulítico e fibroso da isokita, com fibras dispostas radialmente ou em feixes, associada a monazita (mais clara) e clinoenstatita (mais escura, lisa). MEV/BSD. 


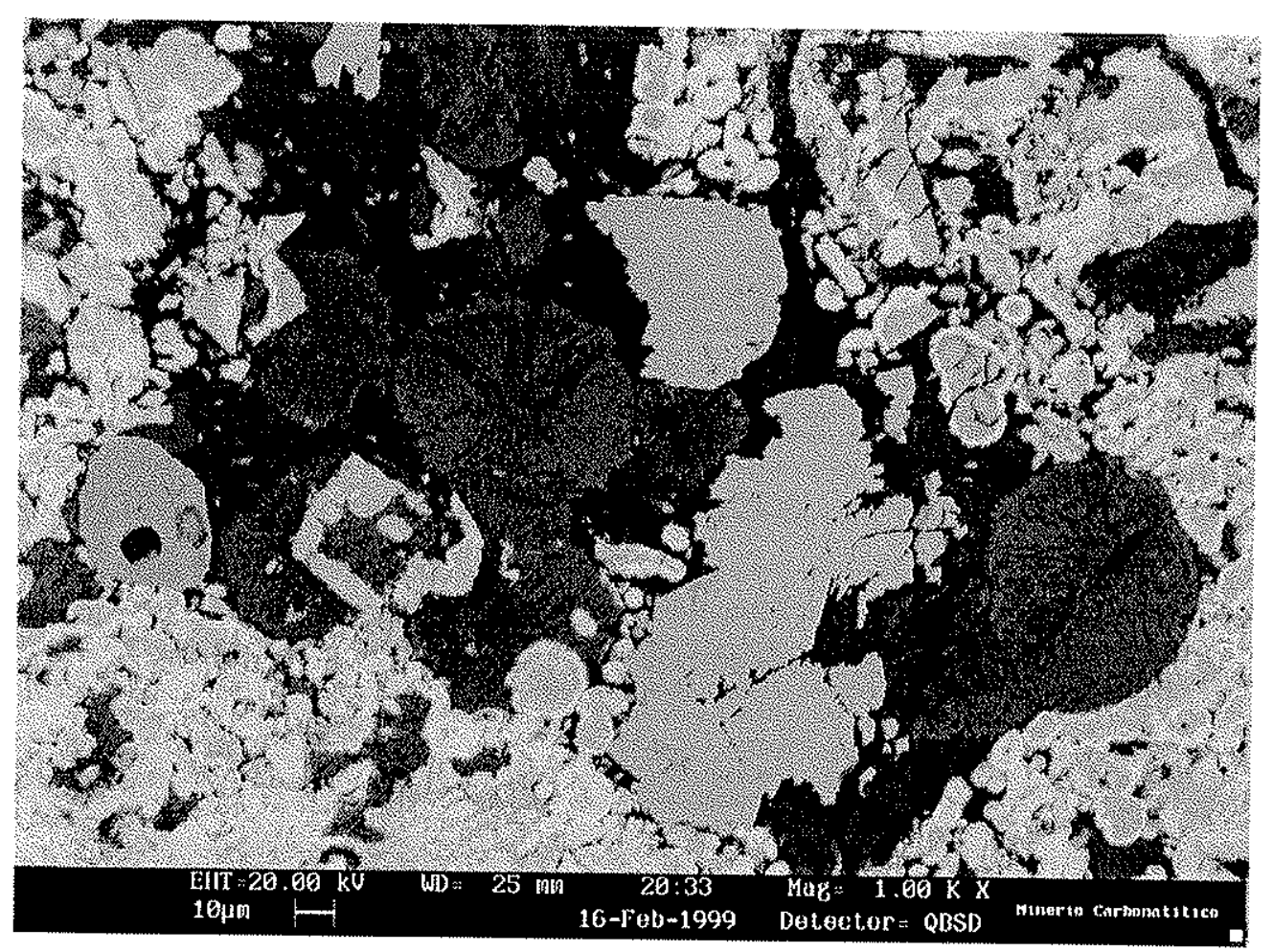

Figura 4.93 - Isokita esferoidal fibrosa associada a monazita (mais clara, com variações de tonalidade de cinza), clinoenstatita (mais escura, lisa) e pouca dolomita (cinza médio, rugoso e não-esferoidal). Na parte central dois cristais grandes de pirita (com níveis de cinza similares aos da monazita mais escura), e no centro à esquerda um grão arredondado de ilmenita. MEV/BSD.

Tabela 4.55 - Composição de isokita (EDS, \% em massa).

\begin{tabular}{lccccc}
\hline $\mathrm{O}$ & 32,1 & 32,1 & 32,7 & 35,2 & 33,6 \\
$\mathrm{~F}$ & 11,5 & 11,4 & 11,0 & 12,9 & 12,8 \\
$\mathrm{Mg}$ & 12,6 & 12,3 & 11,9 & 13,4 & 12,8 \\
$\mathrm{P}$ & 18,3 & 17,3 & 17,5 & 17,9 & 17,6 \\
$\mathrm{Ca}$ & 21,1 & 20,8 & 20,3 & 20,6 & 20,3 \\
$\mathrm{Sr}$ & 2,3 & 1,5 & 2,2 & 1,5 & 1,9 \\
\hline Total & 97,8 & 95,5 & 95,6 & 101,5 & 99,1 \\
\hline
\end{tabular}

Pirita é bastante comum na amostra de carbonatito, e o principal carreador de Fe. Sempre ocorre em gräos maiores, como observado na Figura 4.93. Um grão realmente grande de pirita com barita, da ordem de vários milimetros, foi observado na amostra (Figura 4.94). Apesar de ser o único, ocupa uma porção considerável no testemunho processado. 


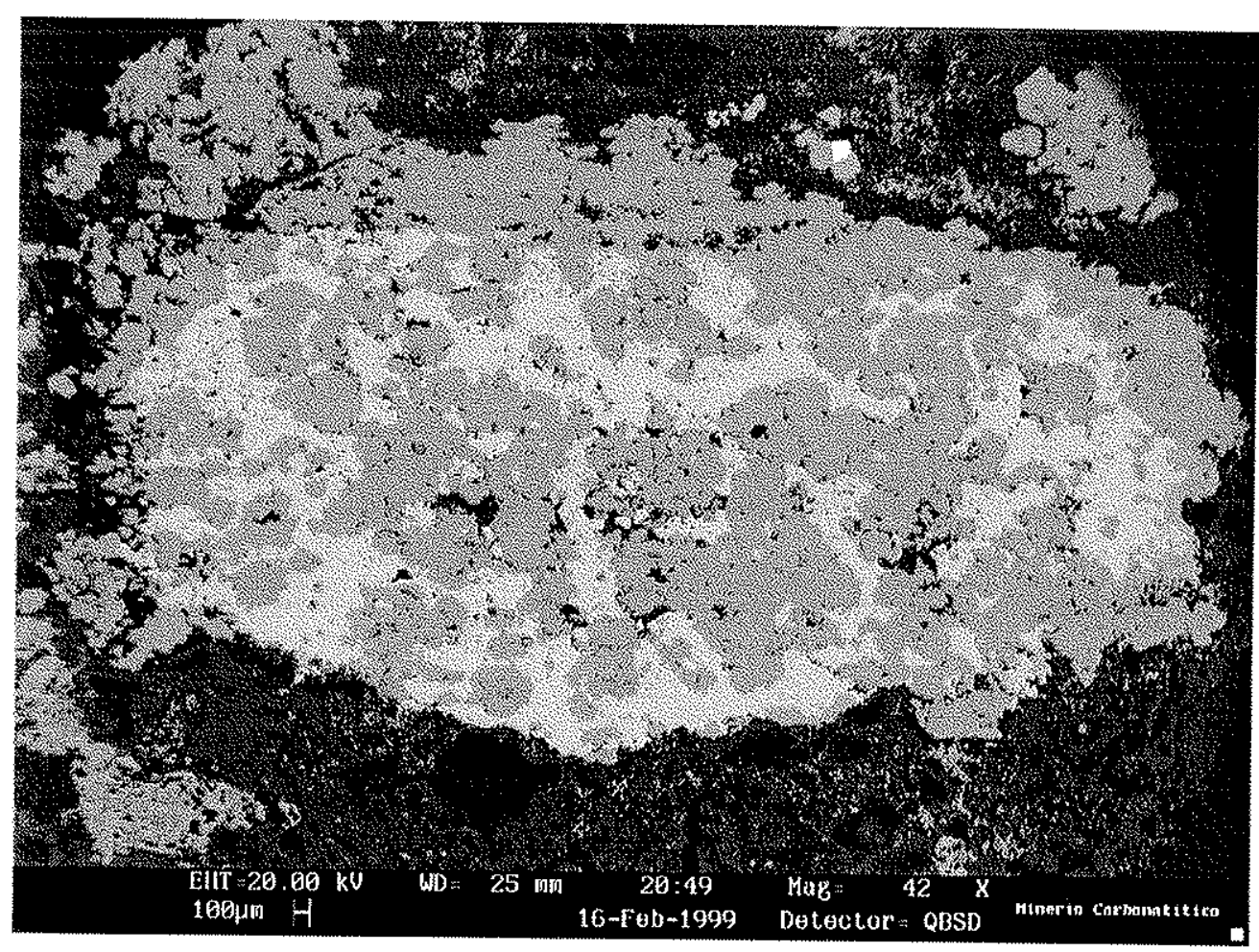

Figura 4.94 - Grande grão de pirita (cinza médio) e barita (cinza claro) no minério carbonatítico, rodeado por carbonatos (magnesita mais escura, dolomita mais clara) e monazita (cinza médio, canto inferior esquerdo), além de um cristal de galena (muito branco, canto superior direito). MEV/BSD.

Além da barita, que só pôde ser observada nessa associação retratada, ainda ocorrem raros cristais de galena, geralmente associados a sulfeto de $\mathrm{Zn}$ (provavelmente esfalerita), como pode ser observado na imagem da Figura 4.95. 


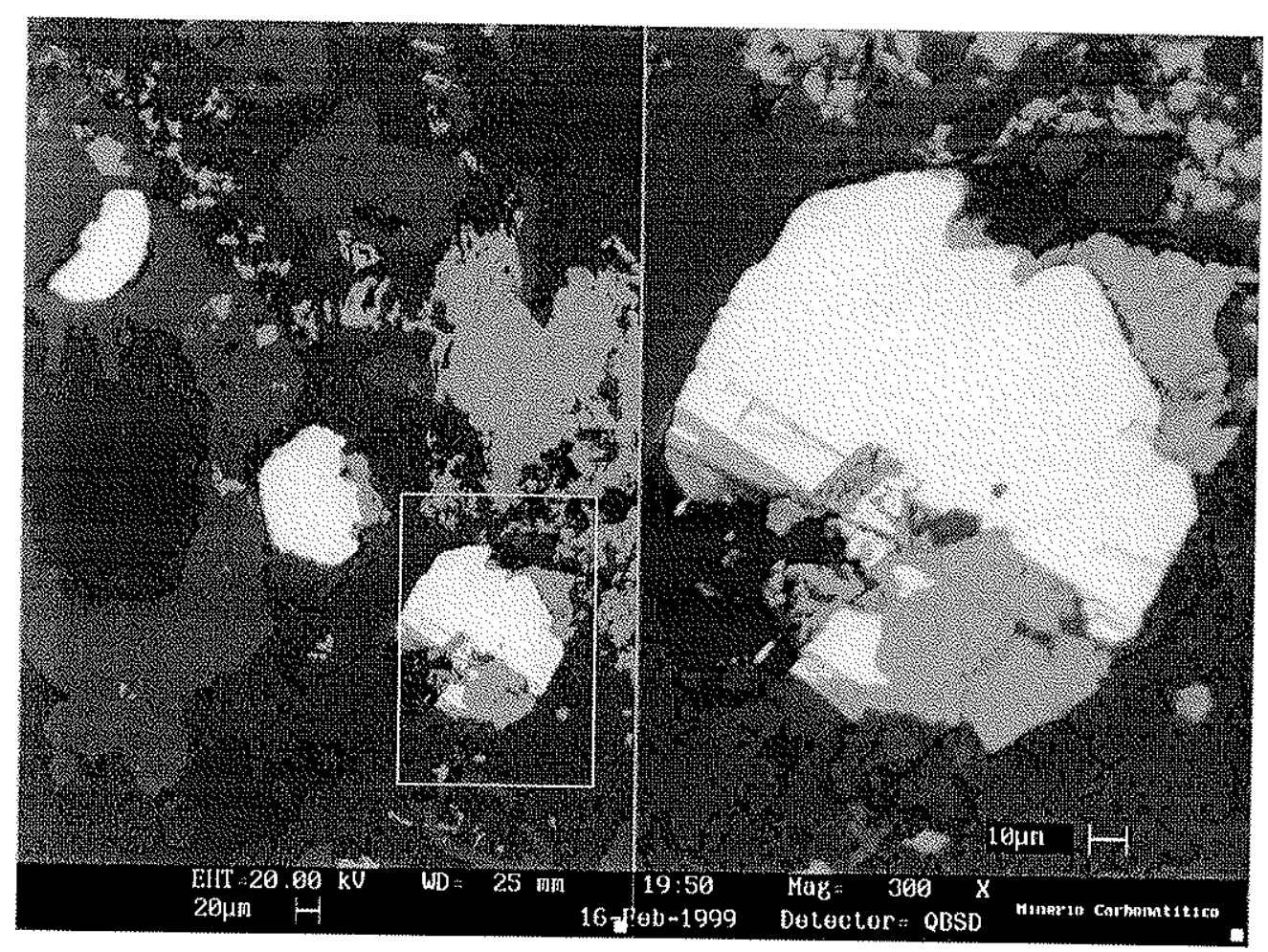

Figura 4.95 - Cristais de galena associados a provável esfalerita (detalhe), em matriz de magnesita (mais escura) e dolomita (menos escura), além de monazita (cinza médio). MEV/BSD.

\section{Análise de lmagens}

As Figuras 4.96 e 4.97 apresentam os diagramas que correlacionam comprimento de intercepto linear, respectivamente, de monazita e de ganga, com a distribuição acumulada relativa, na forma de 1-F( $\ell$ ), e a curva que representa a exponencial múltipla que melhor se ajusta aos dados. As exponenciais obtidas para a monazita (dupla) e para a ganga (tripla), foram:

monazita:

$$
1-F(\ell)=0,09387 * \exp (-0,2170 * \ell)+0,0613 * \exp (-0,0616 * \ell),
$$

ganga:

$1-F(\ell)=0,7313 * \exp (-0,2604 * \ell)+0,1778 * \exp (-0,0165 * \ell)+0,0909 * \exp (-0.0008 * \ell)$ 


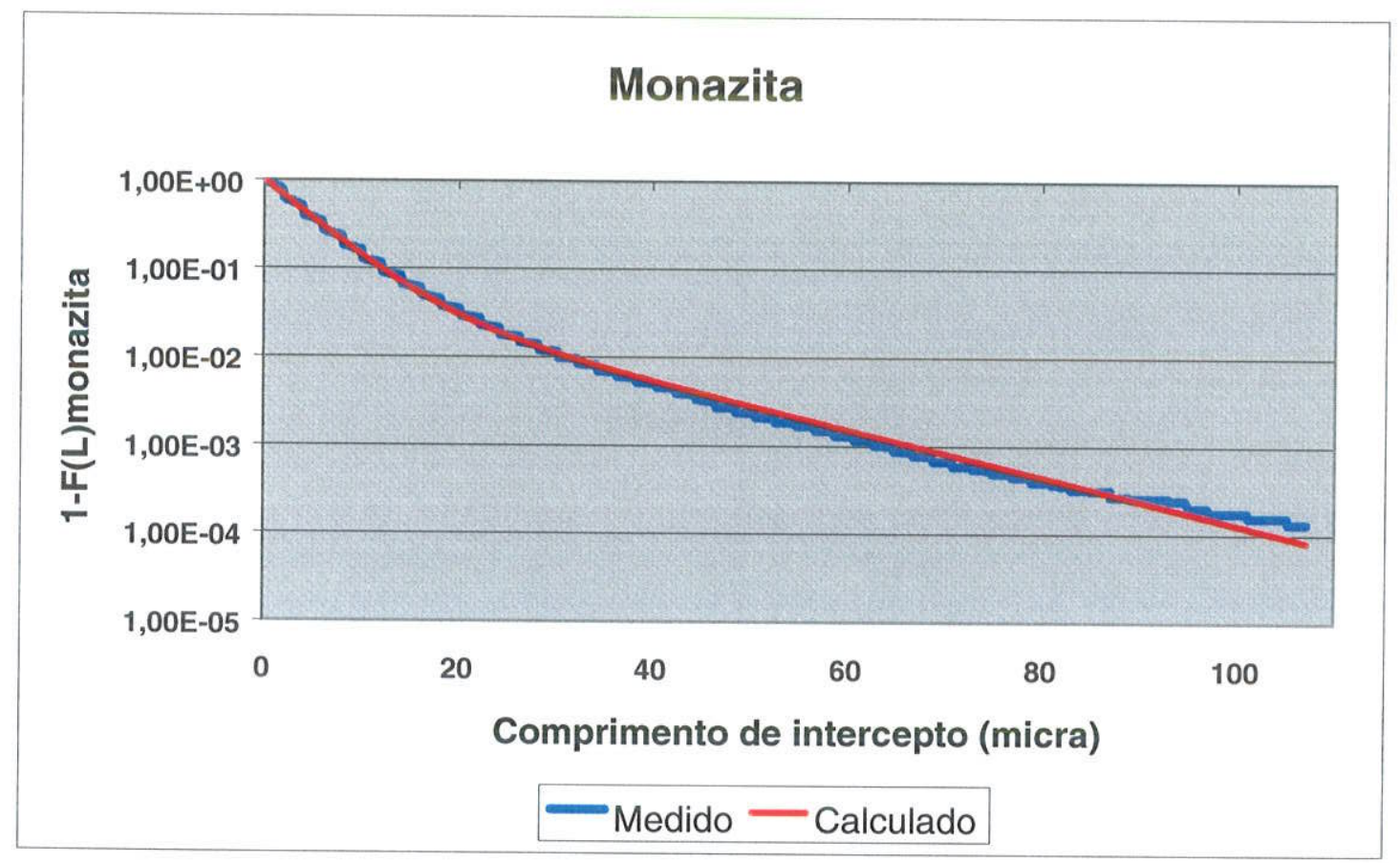

Figura 4.96 - Distribuição de tamanho de interceptos (medida e calculada) de monazita, acumulada e relativa, do minério carbonatítico.

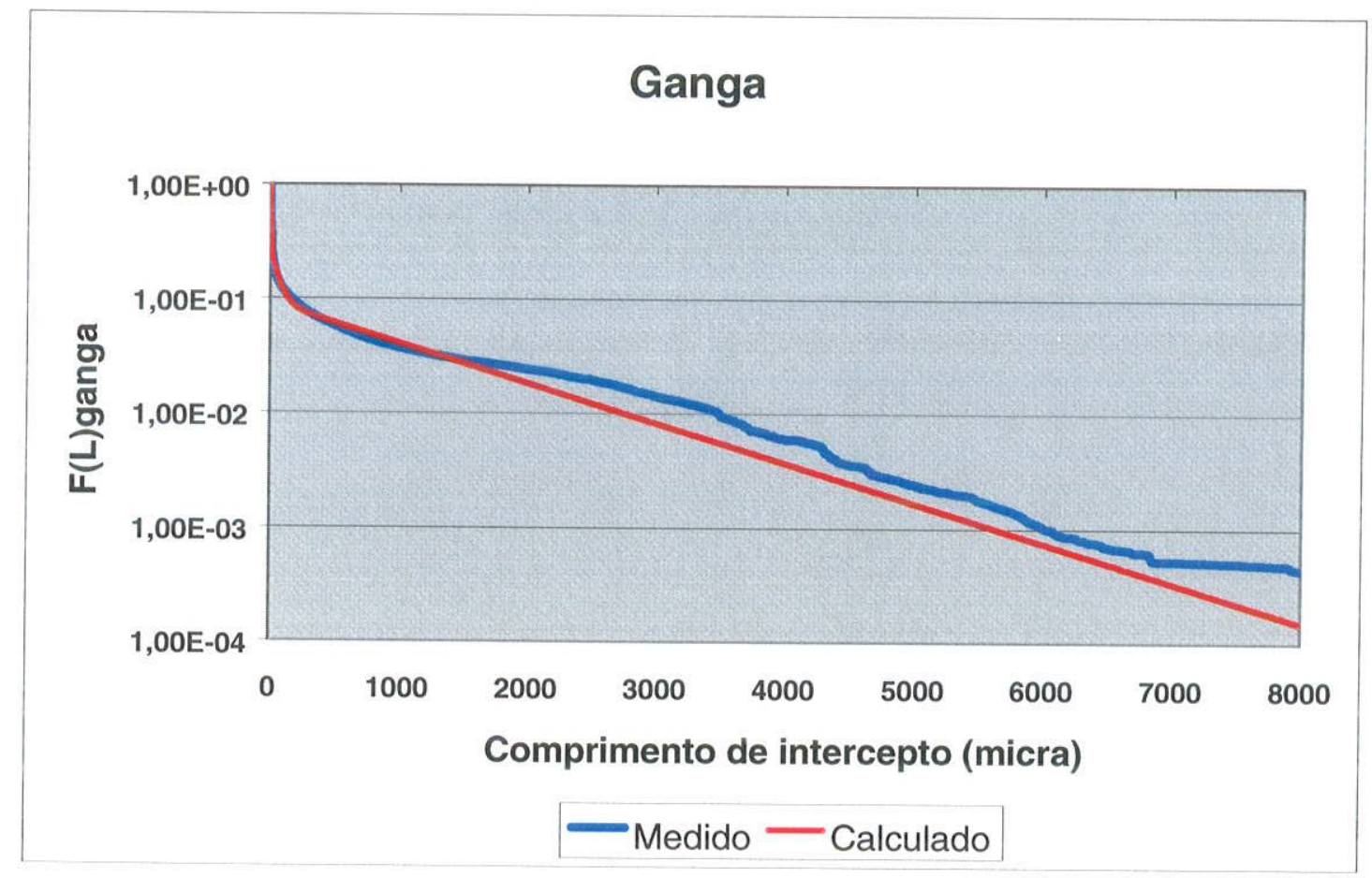

Figura 4.97 - Distribuição de tamanho (medida e calculada) de interceptos de ganga, acumulada e relativa, do minério carbonatítico. 
A feição que logo salta aos olhos é a diferença de diferença dos tamanhos de interceptos, uma vez que os referente à monazita situam-se entre 0 e $100 \mu \mathrm{m}$, e os da ganga entre 0 e 8.000 , da ordem de 80 vezes. Por essa razão a metodologia de aquisição de dados disponível, de análise em imagens convencionais, teve que ser adaptada para medição desses interceptos de ganga e imagens muito largas. A textura de ambos, monazita e ganga, é bem diferente, como pode ser observada pelas curvas de distribuição de tamanhos de intercepto e pelas exponenciais múltiplas correspondentes.

A liberação linear aparente obtida para a amostra de carbonatito mineralizado está graficamente representada na Figura 4.98.

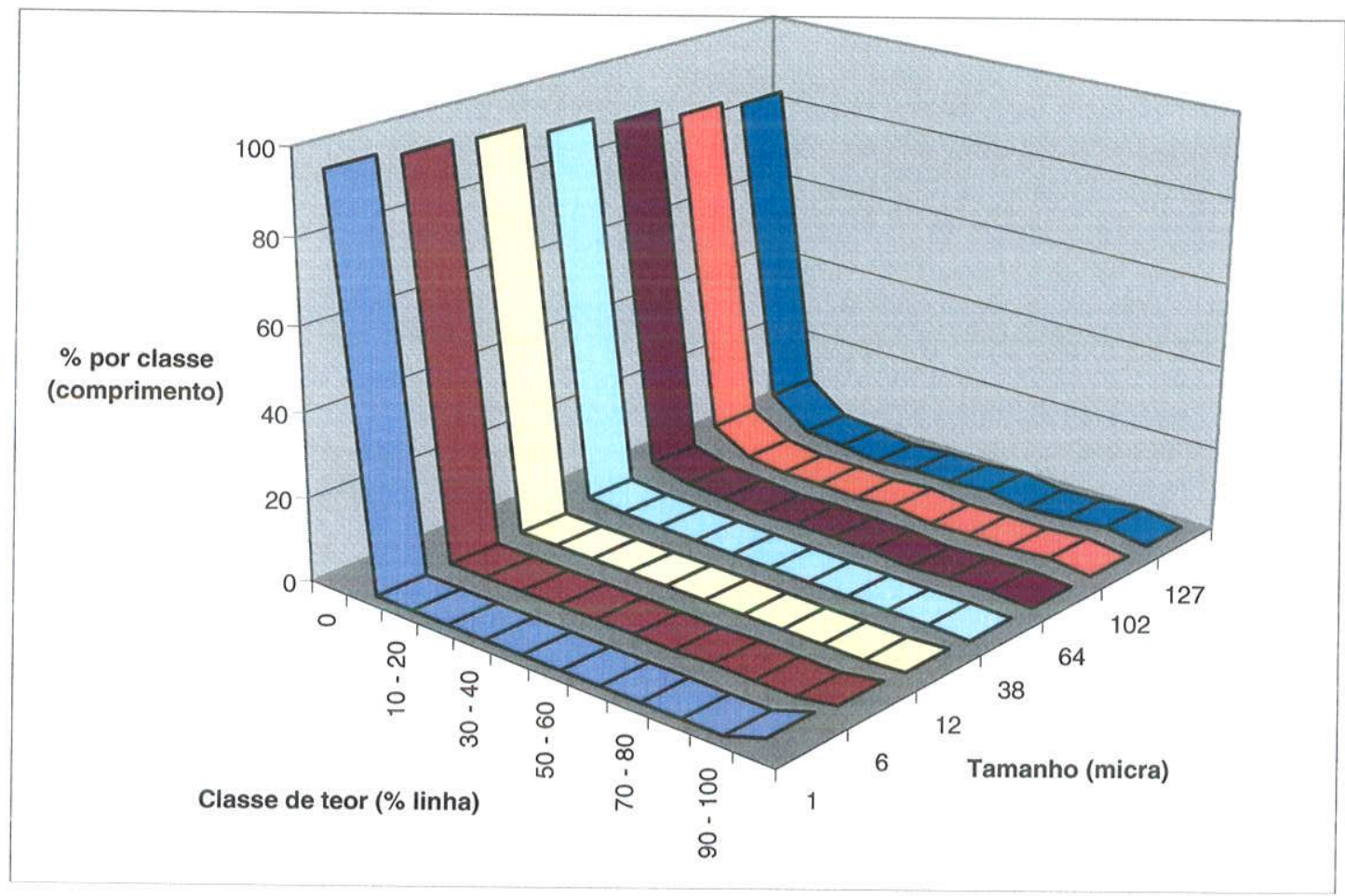

Figura 4.98 - Liberação linear aparente do minério carbonatítico. Condicional por tamanho.

As funções de transformação que melhor se adequaram aos dados de liberação linear, pela análise das L-curves de Hansen, foram dolomita-esfalerita alta resolução 
simétrica para 1 e $6 \mu \mathrm{m}$, dolomita-esfalerita alta resolução para 12, 38 e $64 \mu \mathrm{m}$, e dolomita-esfalerita baixa resolução simétrica para tamanho de partícula maior, 102 e $127 \mu \mathrm{m}$. O espectro de liberação em volume, após correção estereológica usando as funções de transformação acima, está na Figura 4.99.

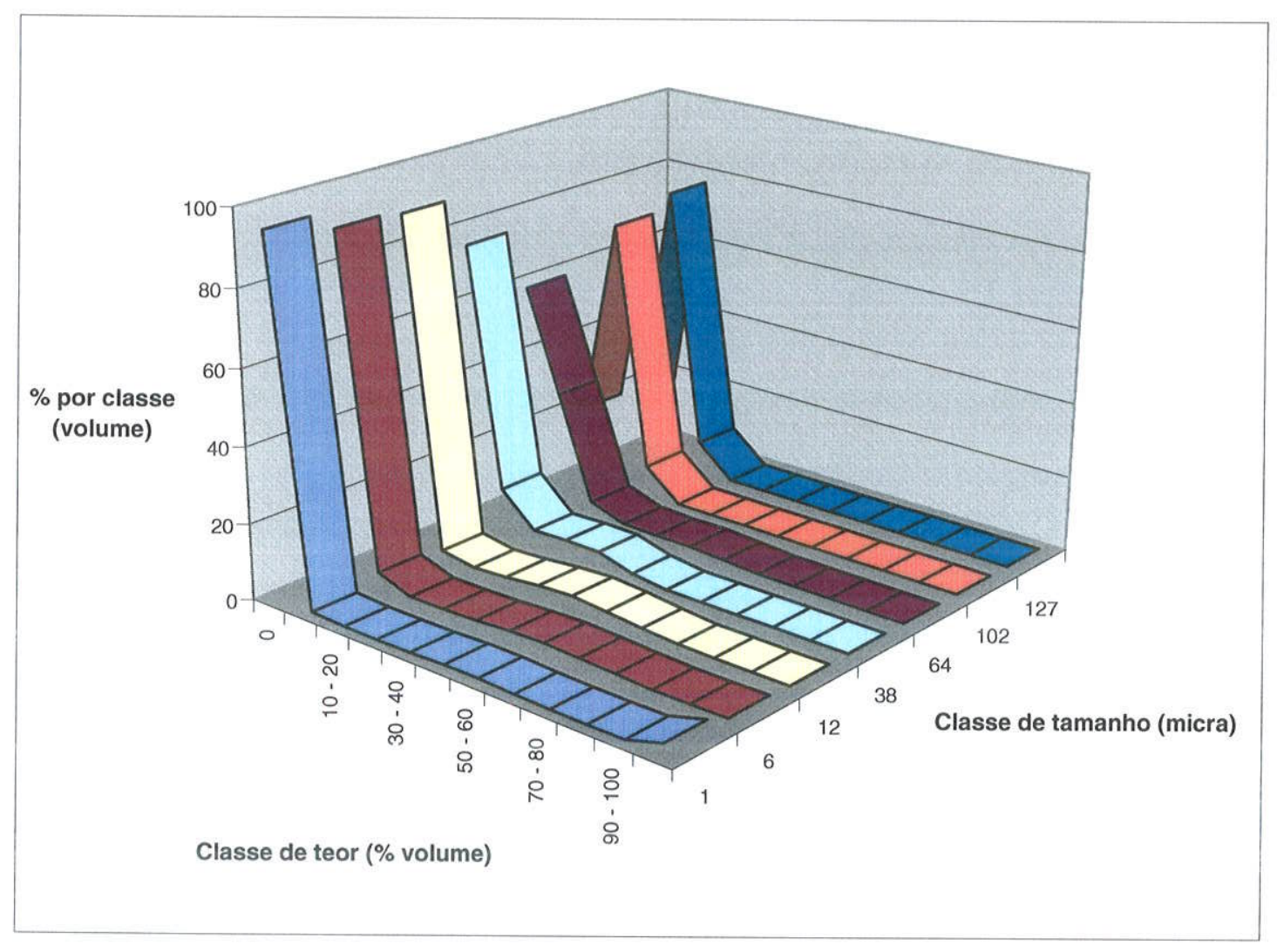

Figura 4.99 - Espectro de liberação em volume, após correção estereológica, do minério carbonatítico. Condicional por tamanho.

Os dados em volume foram convertidos para massa pela aplicação de densidade 5,2 para monazita e 3,0 para ganga, e a liberação em massa da monazita está na Figura 4.100. 


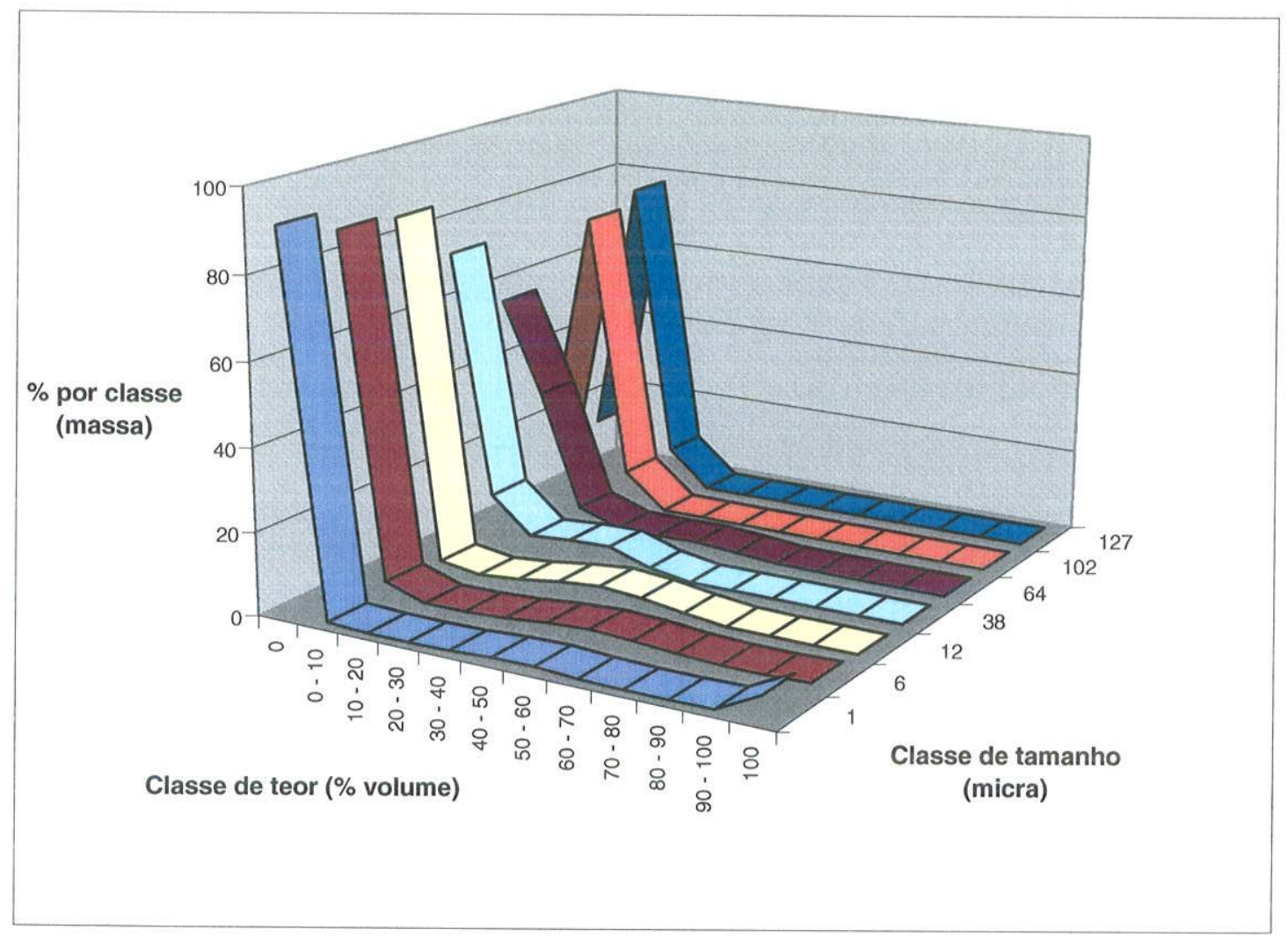

Figura 4.100 - Liberação em massa do minério carbonatítico. Condicional por tamanho.

Esse espectro de liberação é extremamente interessante. Observa-se que até $102 \mu \mathrm{m}$ a liberação da monazita inexiste, e a ganga também está pouco liberada, entre 10 e $20 \%$, apenas. A partir de $64 \mu \mathrm{m}$, a ganga começa a ficar bem liberada - mais de $50 \%$, mas não a monazita. Entre 38 e $6 \mu \mathrm{m}$, pode-se observar que progressivamente a ganga vai sendo liberada das partículas mistas, e que essas partículas vão, assim, melhorando o seu teor em monazita. A $1 \mu \mathrm{m}$ a liberação tanto de ganga quanto de monazita é boa, restando uma porcentagem muito reduzida de partícula ainda não liberada. Essas observações são perfeitamente concordantes com o que se esperaria, intuitivamente, após observar as muitas imagens de monazita ao MEV, uma vez que a dimensão da monazita é dessa ordem, poucos micrômetros. 


\section{CAPITULOO 5 \\ Conclusões}

Os potenciais minérios de terras raras de Catalão I, mais especificamente da região do Córrego do Garimpo, são classificados como silexítico e laterítico, conforme denominação utilizada pela empresa. As reservas estimadas desses dois tipos de minério potenciais atingem 30 milhões de toneladas, com teor médio de $7,56 \%$ de $\mathrm{TR}_{2} \mathrm{O}_{3}$, o que justifica um esforço para desenvolvimento de tecnologia que viabilize a sua explotação em condições economicamente e ambientalmente favoráveis, e que se inicia com uma caracterização tecnológica compatível com a complexidade dos minérios. Um terceiro tipo - carbonatito mineralizado, identificado apenas em alguns testemunhos de sondagem, pode ser potencialmente interessante, mas a profundidade a que foi encontrado $(220 \mathrm{~m})$, a falta de maiores informações quanto às suas reservas e mesmo a ausência de amostra representativa justifica uma caracterização tecnológica preliminar, como subsídio a planejamento futuro de eventual lavra ou mesmo expansão de lavra já existente nos outros tipos de minérios.

O minério silexítico tem um teor de $\mathrm{TR}_{2} \mathrm{O}_{3}$ de $10,05 \%$. Sua composição mineralógica é basicamente quartzo, monazita, hematita e goethita, e subordinadamente barita, cerianita, fluorapatita e hollandita.

O único carreador importante das terras raras é a monazita, uma vez que cerianita não é comum, e sempre se apresenta muito fina $(<0,1 \mu \mathrm{m})$. A monazita pode se apresentar de diversas formas, como agulhas, substituição pseudomórfica de outros minerais e como vermes, mas a forma de ocorrência mais comum é a esferoidal, com camadas concêntricas de monazita. Uma característica marcante é o tamanho sempre reduzido da monazita, usualmente da ordem de poucos $\mu \mathrm{m}$, dispersos na matriz de 
quartzo (tipicamente), minerais de Fe e raramente apatita. Algumas análises semiquantitativas e imagens de microscopia eletrônica de varredura permitiram, inclusive, identificar intercrescimento nanométrico de monazita com quartzo nas camadas concêntricas dos esferóides. A monazita tem uma composição similar à de outros depósitos, com ETR médio de $48 \%$, correspondente a $57,6 \%$ de OTR, e duas importantes diferenças: alto teor de $\mathrm{Sr}$ (da ordem de 3,3\% do elemento), e ausência de Th. O teor elevado de Sr pode significar um subproduto agregando valor ao minério, e a ausência de Th tem importantes implicações ambientais e econômicas (uma vez que é radioativo, tóxico e praticamente não tem mercado, tendo de ser adequadamente estocado). O outro carreador identificado, cerianita, não pode ser considerado um mineral de minério pela sua pequena quantidade. Mas é importante ficar atento à cerianita durante eventual processamento hidrometalúrgico do minério, uma vez que a cerianita é insolúvel em alguns ácidos, como o clorídrico e o nítrico (Abrão 1994), e pode ser responsável pela extração incompleta das terras raras.

A péssima liberação da monazita, certamente decorrente de sua forma de ocorrência, reflete-se na sua distribuição nos produtos separados por tamanho, densidade e susceptibilidade magnética. A única concentração expressiva ocorre na fração fina, abaixo de $20 \mu \mathrm{m}$, que com o teor de $13,3 \%$ de $\mathrm{TR}_{2} \mathrm{O}_{3}$ contém praticamente metade das terras raras, em aproximadamente $36 \%$ da amostra. O ferro, no entanto, também se concentra nos finos, com teor de $8,10 \%$ de $\mathrm{Fe}_{2} \mathrm{O}_{3}$ (43,05\% do total). Apesar de não serem as principais fases de ganga, que no caso é o quartzo, a importância das fases ferruginosas reside no fato de serem as principais consumidoras indesejadas de ácido num eventual processo de extração uma vez que o quartzo é inerte. 
A quantificação direța de liberação da monazita por análise de imagem, após correção estereológica, estipula que menos de $5 \%$ da ganga está liberada da monazita, e que poderia teoricamente ser descartada sem perdas de terras raras. A péssima liberação da ganga em relação à monazita, como contraponto à já esperada péssima liberação da monazita em relação à ganga, encontra respaldo nas observações em detalhe ao MEV, uma vez que muitas das partículas de ganga apresentam pequenas quantidades de monazita, e geralmente na superfície das partículas. Esse fenômeno advém da monazita de Catalão I ser comparativamente muito mais friável do que o principal mineral de ganga, o quartzo, de maneira que a quebra do minério durante a sua cominuição ocorre preferencialmente na monazita. Essa observação tem sérias implicações para o processamento desse minério, uma vez que no processo de uma das principais operações unitárias, a flotação, certamente partículas com monazita na superficie seriam coletadas, apesar de conterem menos de $10 \%$ de monazita. O fato, aliás, de por volta de $65 \%$ das partículas conterem entre 0 e $10 \%$ (em volume) de monazita desqualifica particularmente a flotação como alternativa de processo, sabendo-se que a monazita se localiza preferencialmente na superfície.

A utilização dos diagramas que correlacionam teor de monazita no concentrado, recuperação global da monazita e descarte de massa com os resultados obtidos por Borges et al. (1995), produz resultados surpreendentes. O seu melhor teste de flotação utilizando apenas uma etapa rougher gerou um concentrado com teor de OTR total de $14,82 \%$ (ou $24,7 \%$ de monazita), correspondendo a uma recuperação de $75,25 \%$ dos ETR alimentados, e com descarte de $47,43 \%$ da massa. Segundo o diagrama de teor de monazita contra recuperação, um teor de $24,7 \%$ de monazita no concentrado recupera por volta de $70 \%$ (contra $75,25 \%$ de Borges et al. 1995), e descarta $54 \%$ da massa, utilizando-se o diagrama teor de monazita contra descarte de massa (contra 
47,43\% aferidos em laboratório). Mas a utilização do diagrama de recuperação de monazita contra descarte de massa prevê, para uma recuperação de $75,25 \%$, descarte de $48 \%$ (47,43\% segundo Borges et al. 1995)! Outro teste de Borges et al. (1995), adotando ainda trës etapas de limpeza (cleaner) e uma de scavenger, fez a recuperação cair para $55,0 \%$ ao produzir um concentrado com $15,3 \%$ de OTR, com descarte de massa de $73,54 \%$. No diagrama teor de monazita contra recuperação de massa, 25,5\% de monazita (equivalentes a $15,3 \%$ de OTR) permitem uma recuperação de uns 64\% (55\% medida), e descarte de massa (do diagrama teor de monazita contra descarte de massa) de $60 \%$ (contra $73,54 \%$ dos autores). A recuperação de $55 \%$ dos OTR (ou monazita), segundo o diagrama de descarte de massa em funçăo da recuperação da monazita, permite um descarte de massa de $75 \%$ (medida $73,54 \%$ ), 。 que confere a esse diagrama uma precisão que os dois anteriores não tiveram! Todos os resultados simulando-se a primeira bateria de testes de Borges et al. (1995) são excelentes, mas na segunda bateria as simulações que dependem numericamente da análise química do teor de OTR no concentrado apresentaram um erro maior, e em ambas as aplicações do diagrama de descarte de massa em função da recuperação de monazita os resultados são perfeitos. É possivel especular se o diagrama descarte de massa contra recuperação de monazita elimina efeito de um possivel erro sistemático de análise química, uma vez que descarte é medido diretamente na massa dos produtos da operação, e recuperação relativiza as análises. Ainda especulando, tanto recuperação de monazita quanto descarte de massa apontam para um teor de monazita no concentrado de $33 \%$, ou $19,8 \%$ de OTR, que poderia ter sido o teor que Borges et al. (1995) realmente conseguiram atingir introduzindo uma etapa scavenger e três cleaner no processo, ao invés dos $15,3 \%$ que o laboratório lhe indicou. 
O minério laterítico tem um teor mais baixo do que o silexítico, $8,39 \%$ de $\mathrm{TR}_{2} \mathrm{O}_{3}$, e alto teor de $\mathrm{Fe}_{2} \mathrm{O}_{3}$, seu principal contaminante, da ordem de $23,73 \%$. Esse minério apresenta uma assembléia mineralógica muito rica, que inclui quartzo, fluorapatita, magnetita, ilmenita, hematita, goethita, monazita, gorceixita, priderita, anatásio, diversas variedades de pirocloro, predominando bariopirocloro, vermiculita, filossilicato interestratificado chamado genericamente de hidrobiotita, zirconolita, calzirtita, baddeleyita e zircão. Algumas fases raras com composição mais exótica, como óxidos (ou hidróxidos) de $\mathrm{Ce}, \mathrm{Ba}$ e $\mathrm{Mn}$, Ce e Ti e outras também foram esporadicamente detectadas, mas geralmente são muito finas e raras para qualquer análise conclusiva.

O principal carreador das terras raras também é a monazita. A forma de ocorrência da monazita, nesse minério, varia mais, e a principal é a de monazita maciça mas muito porosa. As associações de monazita mais comuns são com apatita, gorceixita e com os minerais de ferro. A composição da monazita no minério laterítico também é muito similar à do minério silexítico, contendo uma média de 47,6 de ETR, equivalente a $57,1 \%$ de OTR, e tem o mesmo teor de $\mathrm{Sr}(3,3 \%$ em média) e nenhum Th detectado do minério silexítico.

A apatita no minério laterítico é um importante carreador das terras raras, que podem estar em pequenas inclusões de monazita (até poucos $\mu \mathrm{m}$ ), muito comuns, ou no próprio reticulo da fluorapatita. Em termos de processo para concentração estar em microinclusões ou no retículo não faz diferença, uma vez que não serả possível liberar as inclusões de monazita da apatita, mas pode ser importante em eventual etapa de solubilização, com dissolução da apatita e preservação da monazita. Não foi possível quantificar a monazita incluída na apatita. O retículo da fluorapatita, no entanto, contém em média $1,2 \%$ de ETR, equivalente aproximadamente a $1,44 \%$ de óxidos de terras raras totais, o que é um teor muito elevado se for considerada a sua recuperação como 
subproduto da fabricação de ácido fosfórico. Ainda na linha de subprodutos, a fluorapatita do minério laterítico também apresenta um teor muito alto de $\mathrm{Sr}$, com média de $4,2 \%$ do elemento, e que pode superar os $9 \%$ em alguns grãos. A variação no teor de Sr nas apatitas é visivel nas imagens de elétrons retro-espalhados ao MEV, com fases mais ricas no elemento muito mais claras do que as fases mais pobres, e com freqüência associadas no mesmo grão provavelmente como gerações diferentes. Os teores de ETR e de Sr obtidos nesse trabalho são muito superiores aos registrados por outros autores que analisaram a apatita de Catalão 1, mas como se trata de um depósito de ETR dentro do complexo, e $\mathrm{Sr}$ é muito comum em outros minerais, formando inclusive estroncianita no carbonatito subjacente, esses resultados não são inesperados.

Outros carreadores detectados, mas que não representam fases de importância por serem relativamente raros, são os pirocloros, de diferentes composições, mas que podem conter mais de $6 \%$ de OTR. Numa área próxima à das terras raras, dentro do complexo de Catalão I, pirocloro é explotado para produção de $\mathrm{Nb}$, e as terras raras permanecem encapsuladas no rejeito da aluminotermia, junto com os elementos radioativos que provavelmente inibem o aproveitamento desse rejeito. A zirconolita também apresenta um teor elevado de OTR, com média da ordem de 5\%, apesar de ser relativamente rara no minério. Um fato importante é algumas análises de zirconolita acusarem um teor (sempre baixo) de Sc no mineral, elemento com alto valor de mercado. Por outro lado, Th (e raro U) também puderam ser identificados. O Sc também foi analisado em alguns (raros) grãos de baddeleyita, em teores mais elevados, atingindo $1,5 \%$, e numa média de 5 análises de $0,82 \%$. Apesar de serem minerais pouco comuns nesses minérios, é importante que se registre esses dados, uma vez que é possivel que sejam mais abundantes em outra porção do maciço 
alcalino-carbonatítico. A calzirtita tem um teor muito baixo de ETR, em média $0,08 \%$ de $\mathrm{Sc}_{2} \mathrm{O}_{3}$ e $0,04 \%$ de $\mathrm{CeO}_{2}$. O mineral é uma excelente fonte de zircônio, por outro lado, contendo por volta de $70 \%$ de $\mathrm{ZrO}_{2}$, e $0,32 \%$ de $\mathrm{HfO}_{2}$. A última fase carreadora de terras raras que se identificou, essa novamente mais comum, foi a gorceixita. Os teores variam muito, e gorceixitas sem ETR detectável são freqüentes, mas foram medidos até $1,6 \%$ de ETR. Como os minerais do grupo da crandallita são indesejáveis em termos de processo, uma vez que tornam os elementos indisponiveis para recuperação, os baixos teores na gorceixita são um ponto favorável.

Dos minerais que não contém terras raras, ilmenita e anatásio podem conter $\mathrm{Zr}$ e $\mathrm{Nb}$, e a priderita identificada invariavelmente é desprovida de bário, apresentando composição idêntica a um análogo sintético à priderita exclusivamente de potássio apresentado na ficha de difração de raios X (ICDD 1996), e que poderia ser um mineral novo. Os filossilicatos, vermiculita e hidrobiotita, estão frequentemente associados a gorceixita, e quase sempre a óxidos/hidróxidos de $\mathrm{Fe}$, que pode inclusive substitui-los pseudomorficamente.

A análise da distribuição das terras raras imediatamente aponta para uma grande concentração dos elementos nos finos $(<20 \mu \mathrm{m}), 70 \%$ do total em $43,52 \%$ da massa. Nas classes de maior tamanho de partículas, a distribuição dos ETR acompanha a distribuição granulométrica. O mesmo vale para a distribuição em termos de densidade e susceptibilidade magnética. Dessa forma, apenas os finos concentram terras raras, e separação magnética não seria eficiente para esse propósito. O ferro também acompanha a distribuição granulométrica, sem enriquecimento expressivo em nenhuma classe de tamanho. Mas quase $24 \%$ do total de $\mathrm{Fe}_{2} \mathrm{O}_{3}$ se concentra na fração magnética ao imã de mão (de ferrite), possibilitando um descarte de 9,25\% da massa total da amostra, e perda de apenas $1,02 \%$ do total das terras raras. A quase totalidade 
desse descarte, no entanto, ocorre nas partículas mais grossas, onde a magnetita se concentra.

A análise do espectro de liberação do minério laterítico revela que a liberação da monazita em relação à ganga é muito baixa, como é esperado. A liberação da ganga em relação à monazita, no entanto, é bem melhor (à exceção da fração mais grossa, onde predominam partículas contendo entre 0 e $10 \%$ em volume de monazita), e por volta de 50\% (em massa) de todas as partículas são de ganga. Por essa razão é possivel descartar por volta de metade da massa sem perdas de monazita. É importante ressaltar que por volta de $10 \%$ das terras raras não estão na monazita que foi avaliada por análise de imagens, e que descartar $50 \%$ da massa sem perder monazita poderia significar perder até $10 \%$ das terras raras, a maioria supostamente no retículo cristalino da apatita. A partir do descarte de $50 \%$ sem perdas de monazita (que elevaria o teor nos $50 \%$ restantes para $15,4 \%$ de monazita), no entanto, qualquer melhoria no teor do concentrado ou descarte adicional de massa implica em recuperação de monazita menor. A obtenção de um concentrado com $50 \%$ de monazita, por exemplo, implica num descarte de massa de $95 \%$, porém significa perda de aproximadamente $70 \%$ da monazita.

A aplicação dos diagramas obtidos a partir do espectro de liberação da monazita no minério laterítico, para comparação com dados da literatura, infelizmente não é possivel quando a separação das partículas é feita exclusivamente com base em seu tamanho. Dessa forma, os ensaios de flotação convencional (mecânica) e em coluna executadas por Aquino \& Albuquerque (1996), após deslamagem, não podem ser simulados em função do espectro de liberação do minério, assim como os ensaios de Vieira et al. 1998 e Tassinari et al. (1998). 
A alternativa de concentrar as terras raras nos finos naturais realmente parece ser a mais efetiva (talvez a única) para concentração das terras raras, apesar do inconveniente de também concentrar $46 \%$ do Fe. Por analogia com a fração mais fina que foi fracionada por susceptibilidade magnética $(37 \times 20 \mu \mathrm{m})$, seria ainda possível eliminar por volta de $30 \%$ desse Fe por separação magnética de baixo campo, com perda de pouco mais de $2 \%$ das terras raras, mas campos mais intensos pouco melhoram a eliminação de Fe, e provocam perdas consideravelmente maiores de ETR. Um obstáculo importante nesse sentido é justamente o tamanho de partícula muito reduzido, que dificulta boas separações. Tassinari et al (1998) aplicaram esse conceito de concentrar as terras raras nos finos naturais, e conseguiram resultados ainda melhores com até duas etapas de atrição explorando a maior friabilidade da monazita. Seus ensaios de separação magnética, no entanto, não promoveram melhoria significativa no concentrado, talvez porque foi utilizada alta intensidade.

Se for considerado que os dois tipos de minérios estão intimamente associados, e que a explotação terá de ser conjunta, e ainda que o minério a ser produzido será composto por aproximadamente metade de cada tipo, silexítico e laterítico, então não se vislumbra outra possibilidade de processamento que não seja exatamente classificação e descarte da fração grossa. A fração fina, abaixo de $20 \mu \mathrm{m}$, de uma amostra composta por $50 \%$ de minério laterítico e $50 \%$ de minério silexítico teria teores de $12,84 \%$ de $\mathrm{TR}_{2} \mathrm{O}_{3}$ e $16,45 \%$ de $\mathrm{Fe}_{2} \mathrm{O}_{3}$. A proporção entre terras raras e o principal consumidor de ácido num eventual processo hidrometalúrgico é bem desfavorável. Dando continuidade ao raciocínio de se extrapolar o comportamento da fração $37 \times 20$ $\mu \mathrm{m}$ aos finos, uma separação magnética com campo similar ao do imã de mão (da ordem de $2 \mathrm{kG}$ ) não permitiria nenhum descarte de Fe proveniente do minério silexítico, nem perdas de ETR, mas no caso do minério laterítico se aplica o raciocínio 
desenvolvido acima, de forma que um concentrado fino, após separação magnética em baixo campo, teria um teor de $\mathrm{TR}_{2} \mathrm{O}_{3}$ final de $13,55 \%$, e de $\mathrm{Fe}_{2} \mathrm{O}_{3}$ de $13,87 \%$, uma melhoria tímida, ainda mais se for considerado que a separação certamente não será tão eficiente nesse tamanho de partícula, e que talvez melhore um pouco utilizando-se os ensaios de atrição propostos por Tassinari et al. (1998).

Por fim, a análise mineralógica do carbonatito, que se supõe represente um terceiro tipo de minério, sotoposto aos minérios silexítico e laterítico, e que apresenta um teor de $6,64 \%$ de $\mathrm{TR}_{2} \mathrm{O}_{3}$ e $3,56 \%$ de $\mathrm{Fe}_{2} \mathrm{O}_{3}$, acusa magnesita, dolomita, monazita, estroncianita, clinoenstatita, pirita e isokita. Galena, esfalerita, pirocloro, barita e ilmenita são fases subordinadas.

Mais uma vez, a monazita é o único carreador de terras raras importante na amostra. O hábito mais comum da monazita é de prismas hexagonais ocos na sua extensão maior, mas ela também pode ser vermiforme e esferoidal com camadas concêntricas. A monazita também tem composição muito similar à da monazita aferida nos outros tipos de minério, com teor médio de OTR total da ordem de $59,7 \%$, mas o teor de Sr é ainda mais elevado, $4,5 \%$ na média, e variando pouco. Pirocloro seria o único outro mineral contendo ETR detectado $(6,1 \%$ de OTR), mas apenas um cristal foi identificado.

Os minerais de ganga mais importantes são magnesita, dolomita e, subordinadamente, clinoenstatita.

A liberação prevista da ganga do carbonatito inicia-se abaixo de $64 \mu \mathrm{m}$, quando por volta de $50 \%$ está liberada, e vai melhorando com a redução do tamanho das partículas, superando $80 \%$ a $12 \mu \mathrm{m}$, e atingindo $91 \%$ a $1 \mu \mathrm{m}$. Para a monazita, no entanto, prevê-se liberação expressiva apenas a partir de $1 \mu \mathrm{m}$. 
Abrão, A. 1994. Química e tecnologia das terras raras. MCT, CNPq, CETEM, 1994. Série Tecnologia Mineral 66. 212 p.

Aquino, J.A. \& Albuquerque, R.O. 1996. Estudo de beneficiamento físico do minério de terras raras da Ultrafértil. Relatório RC-CT5-09/96 CDTN/CNEN. Inédito.

Asmus, H.E. 1978. Hipótese sobre a origem dos sistemas de zonas de fraturas oceânicas/alinhamentos continentaisque ocorrem nas regiões sudeste e sul do Brasil. In: Brasil. Projeto REMAC 4 (Aspectos estruturais da margem continental leste e sudeste do Brasil): 39-73. Rio de Janeiro. Petrobrás.

Barbery, G. 1991. Mineral liberation: measurement simulation and practical use in mineral processing. Editions GB. Quebec.

Barbosa, J.P.; Araújo, R.V.V.; Cunha, O.G. 1995. Estudo da dissolução seletiva da sílica do minério de terras raras, Catalão - GO. Congresso Anual da ABM, 51, Porto Alegre, 05 a 08 de agosto de 1995. ABM - Associação Brasileira de Metalurgia e Materiais.

Barbosa, O.; Braun, O.P.G.; Dyer, R.C.; Cunha, C.A.B.R. 1970. Geologia da região do Triângulo Mineiro. DNPM, Boletim 136, Divisão de Fomento da Produção Mineral.

Borges, J.A.L.; Almeida, S.L.M.; Costa, L.S.N. 1995. Beneficiamento de minérios de terras raras. Minério do Córrego do Garimpo. Relatório Técnico RT12/95, CETEM/CNPq. Inédito. 
Carvalho, W.T. 1974. Aspectos Geológicos e Petrográficos do Complexo UltramáficoAlcalino de Catalão I, GO. Congr. Bras. Geol, 27, Porto Alegre, 1974. Anais 5: 107-123. SBG.

Danni, J.C.M.; Baecker, M.L.; Ribeiro, C.C. 1991. The geology of the Catalâo I carbonatite complex. In: International Kimberlite Conference, 5, Araxá. Field Guide Book: 25-29. Araxá. CPRM.

DNPM. 1984. Geologia do Brasil - Texto Explicativo do Mapa Geológico do Brasil e da Área Oceânica Adjacente Incluindo Depósitos Minerais. Escala 1:2.500.000. Coord.: Schobbenhaus, C.; Campos, D.A.; Derze, G.R.; Asmus, H.E. Brasília, DNPM.

DNPM/CVRD. 1986. Principais Depósitos Minerais do Brasil. vol. 2. Coordenação Geral: Schobbenhaus, C. e Coelho, C.E.S. Brasília, DNPM.

Dutra, C.V. \& Formoso, M.L.L. 1991. Algumas considerações sobre a distribuição de ETR em apatitas. Congr. Bras. Geoquim, 3, e Congr. Geoquim. dos países de língua portuguesa, 1. São Paulo, 1991. Resumos 2: 640-646.

Gaspar, J.C.; Silva, A.J.G.C.; Araújo, D.P. 1994. Composition of priderite in phlogopitites from the Catalão | carbonatite complex, Beazil. Mineral. Mag. 58: $409-415$.

Hasui, Y. 1968. A Formação Uberaba. Cong. Bras. Geol., 22, Belo Horizonte, MG. Anais: 167-179.

Herz, N. 1977. Timing of spreading in the South Atlantic. Information from brazilian alkaline rocks. Geol. Soc. America Bull 88(11): 101-112.

ICCD. 1996. International Centre For Diffraction Data. Mineral Powder Diffraction File PDF - 2 (CD-ROM). EUA, 1994. 
IUPAC. 1960. Comission on Nomenclature of Inorganic Chemistry. J. Am. Chem. Soc. 82: 5523 .

Imbernon, R.A.L. 1993. Evolução geoquímica e mineralógica dos produtos de alteração intempérica sobre as rochas do complexo alcalino carbonatítico de Catalão I, Goiás. Dissertação de mestrado, Instituto de Geociências, USP. Inédito.

Imbernon, R.A.L.; Oliveira, S.M.B.; Figueiredo, A.M.G. 1994. Concentração dos ETR nos produtos de alteração intempérica do complexo alcalino-carbonatítico de Cataläo I, GO. Bol. Geoc. Centro-Oeste 17(1/2): 25-28.

Jackson, J.A. 1997. Glossary of Geology. 4. Edição. Alexandria, VA. American Geological Institute.

King, R.P. 1978. Determination of particle size distribution from measurements on sections. Powder Technology 21: 147-150.

King, R.P. 1979. A model for the quantitative estimation of mineral liberation by grinding. Int. J. Miner. Processing, 6: 207-220.

King, R.P. 1982. The prediction of mineral liberation from mineralogical texture. Int. Mineral. Cong., 14, Toronto, Canadá. Proceedings. Toronto.

King, R.P.1994a. Linear stochastic models for mineral liberation. Powder Technology 81: $217-234$

King, R.P.1994b. Quantitative characterization of mineralogical texture by image analysis. In: Petruk, W. \& Rule, A.R., Process Mineralogy XII - Applications to environment, precious metals, mineral benecifiation, pyrometllurgy, coal and refractories. TMS, 1994.

King, R.P. \& Schneider, C.L. 1993. An effective SEM-based image analysis system for quantitative mineralogy. Kona 11: 166-177. 
Ladeira, E.A. 1971. O Cretáceo em minas Gerais. Cong. Bras. Geol. 25, São Paulo, SP. Anais 1:15-31.

Lapido Loureiro, E.F.V. Terras-Raras no Brasil: Depósitos, Recursos Identificados, Reservas. MCT, CNPq, CETEM, 1994. Série Estudos e Documentos 21.183p.

Lapido Loureiro, E.F.V. \& Barbosa, J.P. Rare Earths in Brazil: Deposits, Identified Resources and Politics. London: Mineralogical Society of Great Britain and Ireland, The Natural History Museum, 1993. 166p. Abstracts: p.7-9

Lenharo, S.L.R. 1994. Caracterização mineralógica/tecnológica das apatitas de alguns depósitos brasileiros de fosfatos. Dissertação de mestrado, Escola Politécnica, USP. Inédito.

Lottermoser, B.G. 1995. Ore minerals of Mt. Weld rare-earth elements deposit, Western Australia. Transactions of the Institution of Mining and Metallurgy, 104: B 157210.

Morteani, G \& Preinfali, C. 1996. REE distribution and REE carriers in laterites formed on the alkaline complexes of Araxá and Catalão (Brazil). In: Rare earth minerals: Chemistry, origin ana ore deposits.

Neumann, R.; Almeida, S.L.M.; Dassié, M.V.C. 1994 . Technological characterization of the Córrego do Garimpo rare earth ore, Catalão (GO), Brazil. Meeting of the Southern Hemisphere on Mineral Processing 1 (Mineral Processing and Environment): 259-268. Concepción, Chile, 1994. University of Concepción.

Oliveira, S.M.B. \& Imbernon, R.A.L. no prelo. Weathering alteration and REE concentration in the Calalão I carbonatite complex, Central Brazil. J. South American Earth Science. Submetido para publicação. 
Pereira, V.P. 1995. L'altération dans le massif alcalino-carbonatitique de Catalão I Brésil. Evolution minéralogique. Tese de doutoramento, Curso de PósGraduação em Geociências, UFRGS e Université de Poitiers. Inédito.

Rocha, P.C.P. \& Trindade, R.B.E. 1993. Extração de terras raras do silexito de Catalão. Seminário de Metais Não-Ferrosos, 8, São Paulo, 26 a 28 de outubro de 1993. ABM - Associação Brasileira de Metalurgia e Materiais.

Salum, M.J.G. \& Peres, A.E.C. 1998. Influência do uso do magstream na flotabilidade do quartzo - efeiro da densidade do fluido de separação. Encontro Nacional de Tratamento de Minérios, 17, 1: 469-482. Águas de São Pedro, SP, 23 a 26 de agosto cie 1998. ARM.

Sant'Agostino, L.M. 1996. Caracterização tecnológica de um depósito mineral - um estudo de caso: o nióbio de Cataläo I, Goiás. Tese de Doutorado, Escola Politécnica USP. Inédito.

Schneider, C.L. 1995. Measurement and calculation of liberation in continuous milling circuits. Tese de Doutorado (PhD), Departamento de Engenharia Metalúrgica, Universidade de Utah. 356 p.

Schneider, C.L.; Lin, C.L.; King, R.P.; Miller, J.D. 1991. Improved transformation technique for the prediction of liberation by random fracture model. Powder Technology 67: 103-111.

Sonoki, I.K. \& Garda, G.M. 1988. Idades K/Ar de rochas alcalinas do Brasil Meridional e Paraguai Oriental: compilação e adaptação às novas constantes de decaimento. Boletim IG-USP, série científica, 19: 63-85.

Tassinari, M.M.M.L.; Kahn, H. Sant'Agostino, L.M.; Ratti, G.; Barros, L.A.F. 1998. Caracterização tecnológica preliminar no saprolito mineralizado a terras raras associado ao domo alcalino de Catalão I, GO. Encontro Nacional de Tratamento 
de Minérios, 17, 1: 419-432. Águas de São Pedro, SP, 23 a 26 de agosto de 1998. ABM.

Ulbrich, H.H.G.J. \& Gomes, C.B. 1981. Alkaline rocks from continental Brazil. Earth Science Reviews 17: 135-154.

Valareli, J.V. 1971. O minéno de nióbio, titânio e terras raras de Catalão, GO. Tese de livre-docência, mstituto de Geociências e Astronomia, USP. Inédito.

Viera, E.V.; Neumann, R.; Lins, F.A.F. 1993. Concentração do minério saprolíticolaterítico de terras raras do Córrego do Garimpo, Catalão - GO. Encontro Nacional de Tratamento de Minérios, 17, 2: 35-52. Águas de São Pedro, SP, 23 a 26 de agosto de 1998. ABM. 